

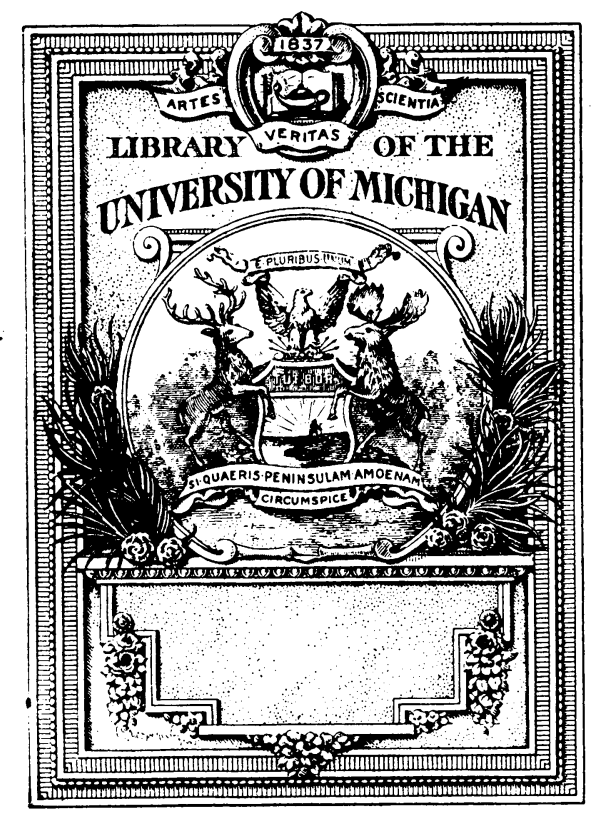


QR
368
45 



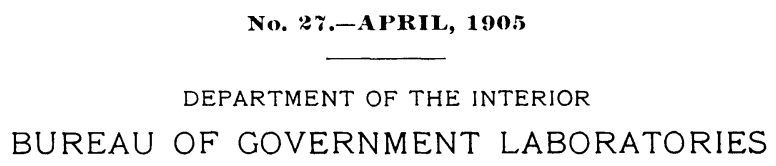

\title{
A REVIEW OF THE IDENTIFICATIONS OF THE SPECIES DEscRibed IN BlanCo's FLORA DE FILIPINAS
}

\author{
$\mathrm{BY}$ \\ ELMER D. 'M"MERRILL, \\ BOTANIST
}

MANILA

BUREAU OF PUBLIC PRINTING 



\title{
LETTER OF TRANSMITTAL.
}

\author{
DePaRTMENT OF - THE INTERIOR, \\ Bureau of Government Laboratories, \\ Office of the Supeisintendent of Laboratories, \\ Manila, P. I., July 251904.
}

SIl: I have the honor to transmit herewith a paper entitled "A Reriew of the Identifications of the Species Described in Blanco's Flora de Filipinas," by Elmer D. Merrill, botanist.

I am, very respectfully.

$$
\text { Paul C. Freer, }
$$

Superintendent of Government Laboratories.

Hon. Dean C. Worcester,

Secretary of the Interior. 



\title{
A REVIEW OH THE IDENTIFICA'IIONS OP THE SPECIES DESCRIBED IN BLANCO'S FLORA DE FILIPINAS.
}

\author{
By Elier D. Merrill, Botamist.
}

\section{INTRODUCTION.}

"Il est à regretter que ces révérends ecclésiastiques (Blanco and Lourciro) et même le Père Plumier, leur prédécesseur, ne se soient pas contentés d'éerire des homélies." Thus A. DeCandolle ${ }^{1}$ expressed his opinion of Blanco's botanical work, an opinion in which all botanists who have occasion to study the Philippine flora will heartily concur.

While we must agree with DeCandolle's opinion regarding Blanco's work, and while undoubtedly the publication of Blanco's Flora de Filipinas has retarded rather than advanced our knowledge of the Philippine flora, still much credit is due to this author for prosecuting his investigations under most unfavorable conditions. The preparation, by the unaided efforts of one man, of a work of the magnitude of Blanco's Flora de Filipinas, with no correspondence with contemporary European botanists, with few reference books, and no authentically named botanical specimens, and where almost every fact noted is the result of the personal observation of the author, is in itself a monument to the zeal and ability of Blanco, and, after a consideration of the circumstances under which the work was accomplished, one can but wonder that the author did not commit more errors.

Blanco's generic and specific descriptions, judged from the standpoint of modern botany, are certainly very imperfect and incomplete, yet many of them are equal or even superior to many of those published by this contemporaries. However, while on the

${ }^{1}$ Phytographie, 141. 
one hand the types of the species described by various European botanists are still perserved in various herbaria in Europe, and an examination of the type specinnen will usually clear up any question existing as to the identity of any doubtful species, on the other the types of all of Blanco's species have been destroyed. It is certain that Blanco had at least a working herbarium, but unfortunately, after his death, the value of his collection was not recognized. Accordingly, to-day we are dependent entirely on his imperfect descriptions for the identification of his species.

In the two editions of the Flora de Filipinas, Blaneo described no less than 1,12\% species and rarieties, of which about 623 were proposed by him as new to seience, and 219 were correctly and 285 incorrectly identified with speeies of other authors. A large pereentage of Blanco's new species are to-day unknown, but the greater proportion will erentually be reduced as synon!ms of those described by other authors. At the present time but 90 are known to be valid. Considering the early date when Blaneo did his work and the fact that the Philippine flora is especially rich in endemic speeies, the percentage of valid ones among those proposed by Blanco is exceedingly small, but this is due to several factors. Most of Blaneo's botanical material was from the immediate ricinity of towns or from thickly settled regions, and accordingly a great proportion of his species were based on widely distributed and cosmopolitan forms. Ho had practically no material from the higher mountains, where the flora is especially rich and interesting; he made no attempt to make his work exhaustive for any one family or group-in fact, he almost entirely ignored such large and critical families as the Orchidarea, Graminece, Cyperacea, ete. He endearored particularly to include all speeies of economic ralue. especially eultivater plants, and he erroneously identified with species of other authors very many which would have been ralid had he given them distinctive specific names.

\section{THE FIRST EDITION OF BLANCO'S FLORA DE FILIPINAS.}

In the year 18:38 there was pullisher in Manila the first edition of Blaneo's Flora de Filipinas, an octaro volume of 887 pages, with an introduction of $i 8$ arditional pages, the latter containing an explanation of the principles of botany of the technieal terms used in the text, of the Linnean system of classifieation, and an enumeration of the genera treated in the work, arranged in classes 
according to the latter. The work is entirely in the Spanish language, and contains the descriptions of 903 species and varieties under Latin and 31 under native names only. 'This work is the only one of its kind treating of the flora of the Philippines, and on account of the many imperfect descriptions, and also due to the fact that the types of Blanco's species were never accessible to European botanists, the publication of this work has caused considerable confusion in the subsequent treatment of the flora of the Philippines and the adjacent Malayan region, although had the types of Blanco's species been preserved his work would have compared very favorably with that of many of his contemporaries. According to Blaneo's statement he had few botanical books, chiefly Linnaeus' Systema Vegetabilium, Jussien's Genera Plantarum, Aublet's Histoire des Plantes de la Guiane francois, and some of the earlier volumes of DeCandolle's Prodromus.

\section{THE SECOND EDITION.}

In 1845, shortly after Blaneo's death, ${ }^{1}$ a second edition of his Flora de Filipinas was published, an octavo volume of 619 pages, very similar to the first one in its style and arrangement, but scarcely an improvement. In the second edition 1,131 species and varieties are described under Latin and 27 under native names only. Six deseribed in the first are excluded from the second, while 198 are arded in the second, and no less than 247 described in the first are included in the second under different generic or specific names. As the descriptions of the species in the second edition contain no references to those in the first, it was in many cases rifficult to correlate the species of the two editions up to the tine of publication of the Novissima Appendix. In some cases the specific or generie names were arbitrarily changed by Blanco, while in others he attempted to identify certain species which were treated of in the first edition with those which had previously been described by other authors. Very few of these changes are correct. In other cases in the first edition he described species under their proper names, which in the second he erroneously altered.

It is frequently rather difficult to determine definitely whether or not Blanco intended to describe a species as new or to identify the same with those of other authors. In some cases, but not always, he indicates these new species. Authorities for species are

${ }^{1}$ Blanco died in Manila April 1, 1845. 
not given, and only when he gives a citation at the end of a description, to Linnaeus, DeCandolle, or other authors, can we be sure that he intended these to represent species of other authors.

Blanco had little conception of geographical distribution, and on the one hand identified many endemic species with those of Asia, and even of tropical America, in the latter being influenced by Aublet's Histoire des Plantes de la Guiane françoise, of which work he had a copy, while on the other hand he described as new many species, native of tropical America, introduced as weeds or as cultivated plants. The second edition like the first follows the Linnean system of classification, with some changes in the sequence of families and genera, but is marred by many typographical errors, which are probably due to the fact that Blanco's death occurred some months before the book was printed, and the correction of the proof devolved on some person who had little or no botanical knowledge.

\section{THE THIRD EDITION.}

The third or Augustinian edition of Blanco's Flora de Filipinas was published in Manila between the years $187 \%$ and 1883, under the auspices of the Order of Augustinians. It is a pretentious publication of four volumes of text and two volumes of plates, and is the work of two Augustinian priests, Andreas Naves and Celestino Fernandez-Villar. The first three volumes practically consist of only a reprint of the second edition with a Latin translation, although in rare instances names that are used for species in the first edition are substituted for those in the second. In the thiril no page references are given to species in the first and second, and accordingly the third edition is of little practical value, and shows no improvement over the second except that it is more available to botanists who have no knowledge of the Spanish language. The authors of the third edition practically succeeded only in extending the data included in the small, convenient octavo volume of the second, through three bulky folio volumes, and in so tloing adder nothing to our knowledge of Blanco's species or to our knowlerlge of the Philippine flora. Volume 1 of the third elition was published in the year $187 \%$ and contains 350 pages, including the species from Monandra, Monogynia to Hexandra, Hexagynia; volume 2 was published in the year 1878 and consists of 418 pages, including the species from Octandria, Monogynia, to Polyadelphia, Polyandra, while rolume 3, published in 1879), consists of $2 \% 1$ pages and 
contains those from Syngenesia to Cryptogamia, and the uncertain species. The fourth volume and the two of plates have no direct connection with the first and second editions of Blanco's Flora de Filipinas, the Novissima Appendix, one of the papers in the fourth volume, being the only part of interest to us here.

\section{THE NOVISSIMA APPENDIX.}

The Novissima Appendix, the third and last article in the fourth volume of the third edition of Blanco's Flora de Filipinas, consists of 375 pages and was published in Manila between the years 1880 and 1883, the last part of the work being printed in June, 1883. This paper in the work of Celestino Fernandez-Villar and Andreas Naves, and upon it the present paper is largely based. The object of the publication of the Novissima Appendix was not only to reduce the species of Blanco's Flora de Filipinas to known ones of older authors but also to enumerate all the species of plants then known from the Philippines. In both cases, but more especially in the former, the authors fell far short of the mark. The authors of the Novissima Appendix made the serious mistake of identifying Blanco's Philippine species with those of other authors from British India and the Malayan region, and, except in the cases of widely distributed and well-known species, nearly all of their identifications are erroneous; and in so identifying Blanco's species they only succeeded in further complicating Philippine botany by credit. ing to the Archipelago scores of species that do not exte $\ldots$ to the Philippines. Of the 1,12\% species and varieties described by Blanco, 5 only were considered by the authors of the Novissima Appendix to be unknown, 1,122 being for most part reduced without question and without discussion to species of other authors. In the present paper it is considered that no less than 289 of Blanco's species are unknown at the present time, notwithstanding the work that has been done on the Philippine flora since the publication of the Novissima Appendix, and in no less than 490 other cases it has been found necessary to change or doubt the identifications of Villar and Naves. It is evident that these authors accomplished their work in the library rather than in the field and in the herbarium, and that they reduced Blanco's species to those of other authors not so much by the study of botanical material as by the examination and comparison of descriptions. It is also very evident that, no matter how well they understood Blanco's species, they had little knowledge of the 
extra-Philippine flora, and very little conception of geographical distribution. While comparatively few of the specific identifications are correct, it is a remarkable fact that very few error's are to be found in their generic identifications.

In the preparation of the manuscript for the Norissima Appendix the treatinent of the Dieotyledons is by Villar, and follows the arrangement of Bentham and Hooker's Genera Plantarum. The Monocotyledons were commenced by Naves and completed by him to page $30 \%$ (Fimbristylis nutans Vahl.), the remainder of the work being by Villar. The last part of the Genera Plantarum was not published in time to be utilized in the treatment of the Monocotyledons.

The Norissima Appendix serves an excellent purpose in that it for the first time correlates the species of the three editions of Blanco's Flora de Filipinas, page references being given to all those described by Blanco in the three editions. Previous to the publication of the Novissima Appendix it was very difficult to correlate the species of the first two editions of the Flora de Filipinas owing to the fact that Blanco changed the names of so many species in the second edition, giving no references to the mames found in the first. The Novissima Appendix also gires us a clew to the proper families and genera of Blanco's species, for it is rare indeed that they are referred to wrong genera.

The identifications of Villar and Naves have been used as a basis of the present work, and these have been accepted in all cases where the facts seem to warrant. Identifications have been discarded in some cases by a careful comparison of descriptions, and in others by a comparison of deseriptions in connection with the known geographieal distribution of species.

\section{GENERA.}

In the first edition of the Flora de Filipinas Blanco described seventeen new genera, four of which were discarded by him in the second, while in the second he described six additional now ones, making a total of twenty-three. Of these twenty-three genera, three-Lunasia, Palaquium, and Malaisia-are recognized to-day as valid: two-Balingayum and Soala-are unknown or uncertain, while the remaining eighteen have been satisfactorily reduced as synonyms of previously established genera of other authors. Of 
the two unknown, soula belongs to the Anonareer. but an scareely be Cyathocalyx, to which it has been reduced by later authors. Balingayum has been redued by rarious authors questionably to Erythropalum, a genus of the Oladacea, while Fernandez-Tillar retains it as a distinct genus of the Onagraeed. Specimens are necessary to determine just what these genera may be, and should be found in the localities eited by Blaneo in his descriptions.

\section{SPECIES.}

Of the 1,12\% species and varieties described by Blanco in the two editions of his Flora de Filipinas, so far as we have been able to determine them, 289 are to-lay either unknown or at least very imperfectly known from Blaneo's deseriptions only. These species which Blanco erroneously identified with those of older authors are of comparatively little importance to us, whether or not such are ever identified they will have no effect on the nomenclature of Philippine botany. Howerer, with respect to those which Blanco described as new to science, it is rery important to hare them properly identified at the earliest date possible. Of the 289 species at present unknown, 65 Blaneo erroneously identified with those of other author's, while 22t were first described by him. Of the total of 1,128 species, 623 were lescribed by Blanco as new, 219 were correctly and 28: incorrectly identified with those of other authors. Of the 623 species described by Blanco as new, so far as known to-rlay, 298 have been satisfactorily reduced as synonyms of those previously describerl, 236 are quite unknown, while of 90 species Blanco's deseriptions are the first known, and his specific names are or should be retained. It is confidently expected that we shall in the future be able to identify a large percentage of these unknown species, many of which will prove to be valid, Blanco's names replacing names of those at present credited to other authors, while many will be satisfactorily reduced as synonyms of previously deseribed species.

\section{THE IDENTIFICATION OF BLANCO'S SPECIES.}

In identifying Blaneo's species numerous factors must be considered, but it is at once erident that the identification of those which are at present unknown will depend primarily on the field worker, and accordingly the present paper has been prepared with the view of aidling collectors in the field. Blanco frequently gives much more 
space and attention to the description of gross characters and to the discussion of the cconomic uses of his species than to an enumeration of strictly technical characters, data and information which the ordinary dried botanical specimen does not show unless the collector's notes are very complete. Accordingly, European botanists, working only with dried material, have been unable to identify many of Blanco's species, but investigators working in the Philippines have been able to do this with little trouble because they have the advantage of knowing the various species as they appear in the field, and have to a greater or less extent the opportunity of collecting in the localities from which Blanco received his material, and of securing data regarding the economic uses of the different species, the native names, and other information which is often essential to correct identification. However, botanists working in the Philippines have been at a disadvantage in that they have not had access to the types of Malayan species in the various European herbaria, and accordingly have in many cases erroneously reduced those of Blanco to entirely different species, which in many cases do not extend to the Philippines.

Blanco's botanical material was, for most part, from the Island of Luzon, very few species being from the southern islands-Mindoro, Negros, Cebu, etc.- - and not a single one from as far south as Mindanao. By far the greater part of his Luzon material came from provinces near Manila, especially from Rizal and Bulacan, while many specimens were from Pampanga, Bataan, Union, Ilocos Sur, and Camarines, few being from other provinces, such as Ilocos Norte, Cagayan, etc. In nearly all cases where Blanco does not cite the locality from which his material was received it is probable that it came from provinces near Manila, at least for the greater part. Very few were from the higher altitudes, and none from the higher mountains. Pinus taeda Blanco, non Linn., Llanosia toquian Blanco, and Blechnum colubrinum Blanco are examples of species from the mountains, but none of these are from the higher peaks.

The native names of plants are a very important factor in the identification of Blanco's species, but these are frequently very local and more or less subject to variation, both in pronunciation and in application. However, as a rule the native names recorded 
by Blaneo are to-day applied to the same species in the same locality, hence it becomes necessary, when collecting with the view to the rediscovery of those of Blanco, to secure, so far as possible, material in the rery towns from which be received his specimens, for frequently a name in almost universal use in one locality to designate a certain species may be quite unknown to natives of a neighboring one, or if used by the latter may be applied to an entirely different species. Native names of species of economic value, those which yield valuable timbers, dyes, and tans, food, fiber, medicines, etc., are frequently quite invariable and are universally used throughout the provinces inhabited by any one tribe of people to designate a certain definite species, and in many cases such plant names are found to be common to several dialects. In questioning natives in regard to the names and uses of plants one will frequently encounter people who have almost no knowledge even of the most common species, and unless the investigator has more or less experience in dealing with natives, and some knowledge of the subject of plant names, he is apt to receive a worthless list, made up for the occasion. However, in every town there will be found a certain number of persons who are thoroughly acquainted with the names and properties of the plants growing in the vicinity, and names sccured from such persons are usually correct, at least for that locality, and can be depended upon. Certain names are used in a generic rather than in a specific sense to designate all species in a closely related group or species which have common characteristics, such as Balcte, for most scandent species of Ficus; Malaruhat, for many species of Jambosa; Dapo, for most epiphytic plants, etc.

The present paper has been prepared in order to summarize in a convenient form our present knowledge of the species of plants described by Blanco and to call especial attention to such as are at present unknown, in order that collectors in the future may have some guide in collecting material which may serve to clear up the identity of some of his unknown species. In the preparation of this paper, wherever Blanco's names are found to be valid, and there is no doubt as to the identity of the species, they have been retained in accordance with the principles of priority. For the best interests of Philippine botany it is rery essential that every effort be made to properly identify the large number of unknown species proposed by Blanco, as with so many in our flora a stable nomenclature can not be established until the majority are properly identified. 
The arrangement of the present paper follows that of the Norissima Appendix. All the species described by Blanco are included with page references in the text under each to the first and second editions of the Flora de Filipinas, while in the general index the same are given to the third edition and to the Novissima Appendix. All the native names given by Blanco have been included. They are only in the following dialects: Tagalog, Pampangan, Visayan, Bicol, and Ilocano, represented respectively by the following letters: T., P., V., B., I. Such data as the date of flowering, locality, size of the plant, and habitat are given in the case of those species which to-day are doubtful or unknown, when such data are given by Blanco. Species of Blanco, of the correctness of the identification of which we are quite certain, are followed by an exclamation mark, while the unknown and uncertain ones are preceded by an asterisk. 


\section{ENUMERATION OF THE SPECIES.}

\section{RANUNCULACEA.}

Atragene zeylanica 13lanco, ed. 1, 461; ed. 2, 321, non Linn. Villar considers that Blanco includes two distinct species in his description and refers J3lanco's species in part to Naravelia zeylanica DC., a species that does not extend to the Philippines, and in part to $\boldsymbol{T}$. laurifolia Wall. Blanco's description seems to include the two species known as Naravelia laurifolia Wall., and Clematis gouriana Roxb., both these species being common and widely distributed in the Philippines. I., Banaibanai, Ovai na panglao.

\section{DILIENIACEAE.}

Dillenia indica Blanco, ed. 1, 472, non Linn.; Dillenia speciosa Blanco, ed. 2, 329, non Thunb. = Dillenia philippinensis Rolfe! T., Catmon.

Delima aspera Blanco, ed. 1, 429; ed. 2, $299=$ Tetracera sarmentosa (Linn.) Vahl.! (Delima sarmentosa Linn.) The pubescent form of this species. T., Malbas tagbalang.

Tetracera monocarpa Blanco, ed. 1, 459; Tetracera sarmentosa (Linn.) Vahl., ed. 2, 320. The latter name is correct.! Erroneously referred by Villar to Tetracera macrophylla Wall., a species that does not extend to the Philippines. T., Malacatmon.

\section{MAGNOLIACEA.}

Magnolia angatensis Blanco, ed. 1, 859; ed. 2, $328=$ Talauma angatensis (Blanco) F.-Vill.! T., Anobling.

Michelia champaca Linn., Blanco, ed. 1, 462; ed. 2, 322.! T., Sampac, Sampaca.

${ }^{*}$ Kadsura blancoi Azaola in Blanco, ed. 2, 594. Reduced by Villar to schizandra elongata Hook. f. et Th., a species that does not extend to the Plilippines. Doubtless a true Kadsura and a good species, possibly represented by No. 23 Loher.

\section{ANONACEAE.}

Unona setigera Blanco, ed. 1, 468; Uvaria setigera Blanco, ed. 2, 323. Reduced by Villar to lvaria purpurea Blume, but is probably a synonym of Uvaria rufa Blume. Blanco's specimens were from Mandaloyon, near Manila.

\footnotetext{
${ }^{1}$ Lnknown species are preceded by an asterisk.
} 
* Unona camphorata 13lanco, ed. 1, 486; ed. 2, 326. Reduced by Villar to Uvaria dulcis Dumal., a species at present unknown from the Philippines. Certainly, however, a species of Uvaria.! A tall scandent shrub in forests, the roots said to have the odor of camphor, bearing fruit in December. 'T., T'aghivalas; V., Dalaganum, Dalagao.

* Soala litoralis Blanco, ed. 1, 437; ed. 2, 304. Reduced by Villar to Cyathocalyx seylanicus ('hamp., a species that does not extend to the Philippines. Certainly not a species of this genus.! Blanco's specimens were from Bauang, Province of Batangas; a weak shrub near the seashore, flowering in July. T., Soal.

Uvaria sinensis Blanco, ed. 1, 465; Unona uncinata Blanco, ed. 2, 324, non DC: Reduced by Villar to Artabotrys odoratissimus R. Br., which is certainly correct.! T., Alangilang sonson.

Unona corniculata Blanco, ed. 1, 469; ed. 2, 326. Reduced by Villar to Artabotrys suaveolens Blume, which is probably correct. Blanco's specimens were from Arayat, Province of Pampanga; the fruit said to be fragrant and edible. P., Susong damolag.

Unona odoratissima Blanco, ed. 1, 467; ed. 2, 325 = Canangium odoratum (Lam.) Baill.! (Cananga odorata Hook. f. et Th.) T., Alangilang.

Unona cabog Blanco, ed. 1, 466; Unona odorata? Blanco, ed. 2, 325. Reduced by Villar to Unona desmos Dumal., which is probably correct. T., Cabog.

Unona ossea Blanco, ed. 1, 46ī; Uvaria ossea Blanco, ed. 2, 322. Reduced by Villar to Unona discolor Vahl., which is certainly correct.!

* Macanea arborea Blanco, ed. 1, 431; Monodora myristica Blanco, ed. 2, 300. This species is transferred by Villar to the genus Monocarpia under the name Monocarpia blancoi F.Vill. If this is the correct genus Blanco's first name should be taken up. A tree known in Cebu and Batangas, flowering in September. T., I'alo calai, Calai, Caningag.

Unona dehiscens Blanco, ed. 1, 466; ed. 2, 325 = Xylopia dehiscens (Blanco) Merrill, Forest. Bureau Bull. 1:20. 1903. (Xylopia blancoi Vidal.) This species was erroneously reduced by Villar to Anaxagorea luzonensis A. Gray.

* Uvaria lanotan Blanco, ed. 1, 464; Unona latifolia? Blanco, ed. 2, 324. Reduced by Villar to Goniothalamus giganteus Hook. f. et Th., which can not be correct according to Blanco's description. Possibly a species of Mitrephora. A tree flowering in March. T., Lanotan.

Uvaria tripetala Blanco, ed. 1, 465, non Roxb.; Unona tripetala Blanco, ed. 2, $324=$ Phaeanthus cumingii Miq.! Erroneously reduced by Villar to Phaeanthus nutans Hook. f. et Th., a species that does not extend to the Plilippines. A tree flowering in August. T., Lanotang itim.

Anona squamosa Iinn., Blanco, ed. 1, 469 ; ed. 2, 327.! T., Ates, Yates. Anona reticulata Linn., Blanco, ed. 1, 470; ed. 2, 327.! 'T., Anonas. 
Anona muricata Limn., Blanco, ed. 2, 326.! T., Guanabanos.

* Uvaria amuyon Blanco, ed. 1, 463; Unona cauliflora Blanco, ed. 2, 323. Reduced by Villar to Melodorum fulgens Hook. f. et Th., but this is certainly an error, as Blanco's species is a tree, while Melodorum fulgens is a large woody climber. T., Amuyon, Grano del Parayso.

\section{MENISPERMACEAE.}

Menispermum rimosum Blanco, ed. 1, 810; ed. 2, 558 non Spreng. $=$ Tinospora crispa Miers.! 'T., Macabuhay; V., Pangiavan, Panavan, Taganagtagua, Paliavan.

Menispermum cocculus Linn., Blanco, ed. 1, 809; ed. 2, $557=$ Anamirta cocculus (Linn.) W. et A.! T., B., P., Lactang, Lictang, Suma, Lanta, Lintang baguin, Tuba, Balasin, Bayati.

Cissampelos pareira Linn., Blanco, ed. 1, 815; ed. 2, 563.! T., Sansao, Sansaosansauan, Calacalamayan, Batangbatang, Cuscusipa, Calaad.

\section{NYMPHAEACEAE.}

Nymphaea lotus Linn., Blanco, ed. 1, 456; ed. 2, 317.! T., B., P., Lavas, Talailo, Gavai gabai, Tunas.

Nymphaea turbinatum Blanco, ed. 1, 458; Nelumbium speciosum Willd., Blanco, ed. 2, 318. The latter name is correct.! T., Baino; I., Sucao.

\section{PAPAVERACEAE.}

Argemone mexicana Linn., Blanco, ed. 1, 454; ed. 2, 316.! I., Casubhang aso.

\section{CRUCIFEREA.}

Cardamine glandulosa Blanco, ed. 1, 521; Cardamine impatiens? Blanco, ed. 2, 363. Referred by Villar to Nasturtium indicum DC., which is undoubtedly correct. Blanco's specimens were from Pasig, Province of Rizal, flowering in January.

Brassica orientalis Blanco, ed. 1, 519; ed. 2, 361 non Linn. Referred by Villar to Brassica nigra Koch., which is probably correct. Blanco's specimens were from Pasig, Province of Rizal, flowering in March.

Sinapis brassicata Linn., Blanco, ed. 2, 362. Referred by Villar, and probably correctly so, to Brassica campestris Linn. Cultivated.

Sinapis sinensis Blanco, ed. 1, 520; Sinapis juncea Linn., Blanco, ed. 2, 362. Referred by Villar to Brassica juncea Hook. f. et Th., which is probably correct. Sp.-Fil., Mostaza.

\section{CAPPARIDACEAE.}

Cleome viscosa Linn., Blanco, ed. 1, 522 ; Polanisia viscosa DC., Blanco, ed. 2, 364. The former name is correct.! T., Balabalanoyan, Apoiapoyan. 
Cleome alliacea Blanco, ed. 1, 522; Cleome alliodora Blanco, ed. 2, $363=$ Pedicellaria pentaphylla (Linn.) Schrank.! (Gynandropsis pentaphylla DC.) T., Balabalanoyan, Apoiapoyan.

* Cleome pentaphylla Blanco, ed. 1, 523; Cleome gigantea Blanco, ed. 2, 364. Reduced by Villar to the American species, Cleome speciosa DC. Blanco states that his species was known in Manila under the name of Araña. Probably a cultivated species, but Blanco does not state this fact.

Crataeva religiosa Forst., Blanco, ed. 1, 399; ed. 2, 279.! I., Balai namoc.

* Capparis baducca Blanco, ed. 1, 438 non Linn.; Capparis mariana Jacq., Blanco, ed. 2, 305. The latter name is possibly correct, Blanco's specimens being from Parañaque, near Manila, said to have been introduced from the Marianne Islands. T., Alcaparras.

Crataeva octandra Blanco, ed. 1, 400; d. 2, 380. Reduced by Villar to Capparis floribunda Wall., which may possibly be correct. Blanco's specimens were from Piddig, Province of Ilocos Norte.

Capparis nemorosa Blanco, ed. 1, 439; C. micracantha Blanco, ed. 2, 305, non DC. Reduced by Villar to Capparis horrida Linn. f., which is probably correct. T., Dauag. I., Talactac.

* Capparis linearis Blanco, ed. 1, 438; ed. 2, 305. Reduced by Villar to Capparis viminea Hook. f. et Th., which is certainly an error; a shrub said by Blanco to be common in forests.

* Capparis odorata Blanco, ed. 1, 439; ed. 2, 305. A species known only from Blanco's description, and one that Villar makes no attempt to reduce. Blanco's specimens were from Angat, Province of Bulacan.

\section{BIXACEAE.}

Bixa orellana Linn., Blanco, ed. 1, 456; ed. 2, 317.! T., Achote.

Banara racemosa Blanco, ed. 1, 425; Flacourtia corollata Blanco, ed. 2, $559=$ Scolopia crenata Clos.! Erroneously reduced by Villar to Scolopia rhinanthera Clos., a species not known from the Philippines. T., Pilapil.

* Banara brevifolia Blanco, ed. 1, 426; Flacourtia parviflora Blanco, ed. 2, 560. Reduced by Villar to Scolopia dasyanthera Benn., a species not known from the Philippines. Possibly identical with Flacourtia ramontchi L'Herit.

Miroxylum decline Blanco, ed. 1, 813; Stigmarota edulis Blanco, ed. 2, $560=$ Flacourtia sepiaria Clos.! T., Bitoñol.

Hydnocarpus polyandra Blanco, ed. 2, 545= Pangium edule Reinw.! V., Pangui.

\section{PITTOSPORACEAE.}

Bursaria inermis Blanco, ed. 2, 124. Possibly identical with Pittosporum ferrugineum Ait. 
Aquilaria pentandra Blanco, ed. 1, 373; Limonia laureola Blanco, ed. 2, 251, non DC. $=$ Pittosporum PENTANDrum (Blanco) (Pittosporum fernandezii, Vidal, in F.-Vill. Nov. App. 13. 1880; Sinopsis, Atlas, t. 8.f. A. 1883; Pittosporum brachysepalum Turcz.! 1854.) Blanco's name is the earliest for this species which is represented by Nos. 500, 1308, 1438, 2804, 2951, and 3177 Merrill. T., Mamalis.

\section{POLYGALACEA.}

Polygala monspeliaca Blanco, ed. 1, 557; ed. 2, 388, non Linn. Reduced by Villar to Polygala telephioides Willd., which is probably correct. Blanco's specimens were from Mandoloyon, near Manila.

Amorpha pedalis Blanco, ed. 1, 553; ed. 2, 387. Reduced by Villar to Salomonia oblongifolia DC., which is probably correct. Blanco's specimens were from Malinta, near Manila, flowering in October.

Securidaca volubilis Blanco, ed. 1, 556, non Linn.; S. ? complicata Blanco, ed. 2, 388, non H. B. K. Reduced by.Villar to Securidaca tavoyana Wall., which is certainly an error, as this species does not extend to the Philippines. Probably identical with Securidaca corymbosa Turcz. The bark is used as a substitute for soap. T., B., P., Gogong bisaya, Gogong bacay, Balago.

\section{CARYOPHYLLACE $A \mathrm{E}$.}

Polycarpon polyphyllum Blanco, ed. 1, 53; ed. 2, 36. Reduced by Villar to Polycarpon loefingiae Benth. et Hook. f., which is probably correct. Blanco's specimens were from Pasig, Province of Rizal, flowering in February.

\section{PORTULACACEAE.}

Portulaca oleracea Linn., Blanco, ed. 1, 407 ; ed. 2, 284.! T., Olasiman, Colasiman; B., Ausiman.

Portulaca meridiana Linn. f., Blanco, ed. 1, 408; ed. 2, $285=$ Portulaca quadrifida Linn.! T., Sayican.

\section{ELATINEAC $\nexists$ E.}

Tillaea rubella Blanco, ed. 1, 75 ; ed. 2, 56. Reduced by Villar to Bergia ammannioides Roxb., which is probably correct. Blanco's specimens were from Pasig, Province of Rizal.

Bergia serrata Blanco, ed. 1, 387; Spergula serrata Blanco, ed. 2, 271. Reduced by Villar to Bergia verticillata Willd., which is probably correct.

\section{HYPERICACEAE.}

Hypericum olympicum Blanco, ed. 1, 613; ed. 2, 429, non Linn. = Cratoxylon blancoi Blume.! Erroneously reduced by Villar to Cratoxylon polyanthum Korth. T., Guyong guyong. 
Hypericum aegyptium Blanco, ed. 1, 615; ed. 2, 430, non Linn. Reduced by Villar to Cratoxylon formosum Dyer, which is probably correct. Blanco's specimens were from Angat, Province of Bulacan, a tree flowering in August.

\section{GUTTIFERE $A$.}

Cambogia binucao Blanco, ed. 1, 434; ed. 2, 302=Garcinia binucao (Blanco) Choisy.! Erroneously reduced by Villar to Garcinia cornea Desrouss. T., Binucao; V., Bagobago.

Cambogia venulosa Blanco, ed. 1, 435; ed. 2, 302 = Garcinia venulosa (Blanco) Choisy.! Erroneously reduced by Villar to Garcinia cornea Linn., a species that does not extend to the Philippines. A tree flowering in August. T., Taclang anac.

* Stalagmites ? cambogioides Blanco, ed. 2, 301, non Murr. Certainly a species of Garcinia.! This species is not mentioned by Villar in the Novissima Appendix. Blanco's specimens were from Bauang, Province of Batangas, a tree flowering in August. T., Banago.

- Cambogia crassifolia Blanco, ed. 2, 304. Reduced by Villar to Garcinia cowa Roxb., which is undoubtedly an error. Blanco's specimens were from Cebu. V., Sagudan.

* Tovomita pentapetala Blanco, ed. 1, 432; ed. 2, 301. This species was transferred by Villar to Ochrocarpus, as a distinct species, Ochrocarpus pentapetalus (Blanco) F.-Vill. It is, however, known only from Blanco' description. A tree flowering in December, growing along the seashore in the Provinces of Ilocos Norte and Ilocos Sur. I., Darigayos, Pamitlain, Pamitlatin.

* Willughbeia multilocularis Blanco, ed. 1, 131; ed. 2, 94. This species was first referred by Villar to the Apocinacex, but in the Addenda et Corrigenda he refers it to Garcinia ovalifolia var. spicata Hook. f. et Th. Possibly correct as to the genus, but certainly not this species. A tree flowering in August. T., Malabatoan.

Calophyllum inophyllum Linn., Blanco, ed. 1, 612; ed. 2, 428.! T., Palo maria, Bitanhol, Tamauian, Dancalan, Dincalan; B., Dincalan, Bitaog; P., Bitaog, Palo maria; I., Bitaog.

* Calophyllum apetalum Blanco, ed. 2, 429, non Willd. Reduced by Villar to Calophyllum pulcherrimum Wall., a species that does not extend to the Philippines. Possibly identical with Calophyllum spectabile Willd. Blanco's specimens were from Angat, Province of Bulacan. T., Malabocboc.

Plinia paniculata Blanco, ed. 1, 423; ed. 2, $296=$ Kayea paniculata (Blanco) Merrill, Govt. Lab. Publ. 17 :29. 1904. Erroneously reduced by Villar to Kayea racemosa Pl. et Tr., a species that does not extend to the Philippines. T., Guisan. 


\section{TERNSTROEMIACEA.}

Guettarda vermicularis Blanco, ed. 1, 723 ; ed. 2, 500. Reduced by Villar to Anneslea fragrans Wall., a species that does not extend to the Philippines. Probably identical with Anneslea crassipes Hook. Blanco's specimens were from the seashore, Bauang, Province of Batangas; a shrub, flowering in October. T., Malatibig.

Llanosia toquian Blanco, ed. 2, $319=$ TAonabo Toquiar (Blanco) (Ternstroemia toquian F.-Vill.!) This species is certainly represented by Nos. 2288 and 3206 Merrill; 150, 137, and 208 Forestry Bureau, collected by Barnes, and No. 57 Alern, Blanco's description in some respects being erroneous. Gilg, in Engler und Prantl, Natürlichen Pflanzenfamilien retains Llanosia as an imperfectly known genus of the Dilleniacex. T., Toquian.

* Camellia sasanqua Blanco, ed. 2, 371 non Thunb. This species is reduced by Villar to Camellia drupifera Lour., but this identification is very doubtful. Blanco's specimens were from a plant cultivated in Manila.

Salceda montana Blanco, ed. 2, 374 = TheA montana (Blanco) (Camellia lanceolata F.-Vill., non Seem.). Nos. 304, 441 Whitford; Nos. 1905, 2778, 2402 Forestry Bureau. Blanco's specimens were from Angat, Province of Bulacan.

* Helianthemum triflorum Blanco, ed. 2, 309. Reduced by Villar to Archytaea vahlii Choisy, which is undoubtedly an error. Blanco's specimens were from Angat, Province of Bulacan; flowering in February. T., Iring.

\section{DIPTEROCARPACEAE.}

Mocanera mayapis Blanco, ed. 1, 449; Dipterocarpus mayapis Blanco, ed. 2, $313=$ Anisoptera vidaliana Brandis?; Dipterocarpus turbinatus F.-Vill., non Gaertn.! Blanco's species is probably identical with Anisoptera vidaliana Brandis, although Blanco describes the petioles as short. This is apparently one of the most common species of Dipterocarpacea in Luzon, and is universally known to the Tagalogs as Mayapis, the name cited by Blanco. Blanco's specimens were from the mountains near Angat, Province of Bulacan. T., Mayapis.

Mocanera vernicifluua Blanco, ed. 1, 540; Dipterocarpus vernicifluus Blanco, ed. 2, 314. The latter name is the correct one, Dipterocarpus velutinus Vidal being certainly a synonym. Erroneously referred by Villar to Dipterocarpus hispidus Thwaites. T., Panao, Balao, Malapao.

Mocanera grandiflora Blanco, ed. 1, 451; Dipterocarpus grandiflorus Blanco, ed. 2, 314.! The latter name is correct. Erroneously referred by Villar to Dipterocarpus griffithii Miq., a species tlat does not extend to the Philippines. T., Apiton, Hapiton. 
Mocanera thurifera Blanco, ed. 1, 446; Dipterocarpus thurifer Blanco, ed. 2, $310=$ Anisoptera thurifera (Blanco) Blume.! T., Sandana, Lauan; B., Lauaan.

* Vatica sinensis Blanco, ed. 1, 401; ed. 2, 280, non Gmel. Reduced by Villar to Vatica grandiflora Dyer, but this species does not extend to the Philippines. Said by Blanco to be closely related to Vatica mangachapoi, and probably only a form of that species. Blanco's specimens were from San Mateo, Province of Rizal.

Vatica mangachapoi Blanco, ed. 1, 401; Vatica apteranthera Blanco, ed. 2, 281. Erroneously reduced by Villar to Vatica scaphula Dyer, a species that does not extend to the Philippines. The first name is the correct one. T., Mangachapoi.

Mocanera polysperma Blanco, ed. 1, 448; Dipterocarpus polyspermus Blanco, ed. 2, $312=$ Shorea Polysperma (Blanco). Erroneously referred by Villar to Shorea talura Roxb., a species that does not extend to the Philippines. This distinct species is represented by Nos. 606, 734, 787, and 819 Forestry Bureau. T., Tangili.

* Dipterocarpus palosapis Blanco, ed. 2, 312. Erroneously referred by Villar to Shorea floribunda Kurz, a species that does not extend to the Philippines. Probably a Shorea, but known only from Blanco's description. T., Palosapis.

Mocanera malaanonan Blanco, ed. 1, 858; Dipterocarpus malaanonan Blanco, ed. 2, 312 = Shorea malaanonan (Blanco) Blume. Probably a distinct species, but not well-known. Blanco's specimens were from Angat, Province of Bulacan. T., Malaanonan.

* Euphoria malaanonan. Blanco, ed. 1, 289; Euphoria? nephelium ? Blanco, ed. 2, 200. Reduced by Villar to shorea robusta Gaertn. f., which is certainly an error, at least as to the species, possibly identical with the preceding species. Blanco's specimens were from Angat, Province of Bulacan, his material being very imperfect. T., Malaanonan.

Mocanera guiso Blanco, ed. 1, 449; Dipterocarpus guiso Blanco, ed. 2, $313=$ Shorea guiso (Blanco) Blume.! Erroneously reduced by Villar to Shorea robusta Gaertn. f., a species that does not extend to the Philippines. T., Guiso, Guijo.

Mocanera plagata Blanco, ed. 1, 447; Dipterocarpus plagatus Blanco, ed. 2, $311=$ Hopea plagata (Blanco) Vidal.! Erroneously referred by Villar to Shorea reticulata Thwaites, an extra-Philippine species. T., Yacal, Sapolongan.

* Mocanera mangachapoi Blanco, ed. 1, 450; Dipterocarpus mangachapoi Blanco, ed. 2, 313= Shorea mangachapoi (Blanco) Blume.! This species is known only from Blanco's description, and should not be confused with Vatica mangachapoi Blanco. Blanco's specimens were from Angat, Province of Bulacan, and from San Mateo, Province of Rizal. T., Guisong dilao, Mangachapoi. 


\section{MALVACEAE.}

Althaea sinensis Blanco, ed. 1, 552, non Cav.; A. rosea Cav., Blanco, ed. $2,386 . !$ The latter name is correct.

Malva coromandelina Blanco, ed. 2, 551, non Cav.; Malva Iuzonica Blanco, ed. 2, $385=$ Malvastrum tricuspidatum A. Gray.! T., Quinalumpang.

Sida lanceolata Roxb., Blanco, ed. 1, 548; Sida frutescens Blanco, ed. 2, 384, non Cav. = Sida carpinifolia Linn.! 'T., V., P., Ualualisan, Escobang haba, Pamalis, Higot balato, Mamalis. I., Taquing baca.

Sida truncatula Blanco, ed. 1, 548; Sida philippica DC., Blanco, ed. 2, $283=$ Sida rhombifolia Linn. var.! T., Escobang bilog.

Sida semicrenata Link., Blanco., ed. 2, $384=$ Sida rhombifolia Linn. var.!

Sida indica Linn., Blanco. ed. 1, 547; ed. 2, $283=$ Abutilon indicum (Linn.) G. Don.! T., Cuacuacohan, Guling gulingan, Tabing, Malis, Dalupang, Palis, Malvas de Castilla.

Napea latifolia Blanco, ed. 2, $387=$ Malachra capitata Linn.!

Napea scabra Blanco, ed. 1, 553; ed. 2, 386, non Linn. This is Malachra lineariloba Turcz.!, erroneously reduced by Villar to Malachra bracteata Cav., an American species. T., Lapnis na bolohan, Anabo. V., Vocabul.

Urena multifida Blanco, ed. 1, 540; ed. 2, 378, non Cav. = Urena lobata Linn.! T., V., P., Colotan, Colotcolotan, Molopolo, Dalupan.

* Hibiscus batacensis Blanco, ed. 1, 544; ed. 2, 380. Reduced by Villar to Kosteletzyka, as a distinct species $K$. batacensis (Blanco) F.-Vill. A species known only from Blanco's description, whose specimens were from the town of Batac, Province of Ilocos Norte.

Hibiscus bifurcatus Blanco, ed. 1, 545; ed. 2, $380=$ Hibiscus surratensis Linn.!

Hibiscus abelmoschus Linn., Blanco, ed. 1, 545; ed. 2, 380.! T., Castoli, Castiocastiogan, Dalupan. V., Maricum Ducum, Marucum, Maropoto, Sapinit. P., Castiocastiolan.

Hibiscus tiliaceus Linn., Blanco, ed. 1, 541; ed. 2, 379.! T., P., Balibago. V., Malibago, Raguindi.

Hibiscus rosa-sinensis Linn., Blanco, ed. 1, 543; ed. 2, 379. ! T., V., P., Tacurangan, Arogangan, Antolangan, Cayanga, Tapolanga, Tarocanga, Gomamila. I., Cayanga rosa.

Hibiscus mutabilis Linn., Blanco, ed. 1, 546; ed. 2, 381.!

Thespesia sublobata Blanco, ed. 2, $382=$ Thespesia lampas D. et G.!

Hibiscus populneus Linn., Blanco, ed. 1, 544; Thespesia populnea (Linn.) Corr., Blanco, ed. 2, 381. The latter name is correct.! T., Boboi gubat.

Thespesia banalo Blanco, ed. 2, $382=$ Thespesia macrophylla Blume.! T., Banalo, P., Banaro, V., Banago. 
Gossypium herbaceum Linn., Blanco, ed. 1, 534; ed. 2, 374; G. religiosum L., Blanco, ed. 2, 374. T., Bulac.

Gossypium paniculatum Blanco, ed. 1, 539; ed. 2, $378=$ Gossypium barbadense Linn. var.! I., Capas.

Gossypium perenne Blanco, ed. 1, 537; ed. 2, $376=$ Gossypium arboreum Linn.! T., Bulac na monti, Bulac na totoo, Bulac cahoy.

Melaleuca grandiflora Blanco, ed. 1, 615; Bombax ceiba Linn., Blanco, ed. 2, 372. The latter name is correct.! T., Taglinao, Malabulac.

Bombax pentandrum Linn., Blanco, ed. 1, 531; ed. 2, 371=Ceiba pentandra (Linn.) Gaertn.! (Eriodendron anfractuosum DC.) T., Boboi, V., Doldol, P., Bulac castila.

\section{STERCULIACEAE.}

Sterculia foetida Linn., Blanco, ed. 1, 763; ed. 2, 524.! T., Calumpang, I., Bangar.

Sterculia cordifolia Blanco, ed. 1, 764; ed. 2, 525, non Cav. = Sterculia philippinensis Merrill, Govt. Lab. Publ. 17:29. 1904. Erroneously reduced by Villar to Sterculia urens Roxb., a species that does not extend to the Philippines. T., Banilad, Banilar.

Sterculia balanghas Blanco, ed. 1, 765; ed. 2, 525, non Linn. Reduced by Villar to Sterculia rubiginosa Vent., a species that does not extend to the Philippines. Apparently the same as Sterculia cuneata R. Br. T., Nato, Malabunot.

Sterculia alata Blanco, ed. 2, 525, non Roxb. = Sterculia blancoi Rolfe.! Villar erroneously considered that Blanco's species was identical with that of Roxburgh.

Heritiera tinctoria Blanco, ed. 1, 653; ed. 2, $456=$ PтERocymbiUm TINCTORIUM (Blanco) (Pterocymbium javanicum R. Br.; Sterculia campanulata Wall.) Blanco's name is the earliest one published for this species and should be retained. T., Taloto, V., Duha?, Busain.

* Sterculia glandulosa Blanco, ed. 1, 764. This species is known only from Blanco's short and imperfect description, and is excluded from the second edition. No locality or native name is given.

* Sterculia glomerata Blanco, ed. 1, 764; ed. 2, 525. This species is quite unknown, but is probably a species of Myristica as suggested by Villar. A tree having a red gum. T., Hindurugu.

* Sterculia decandra Blanco, ed. 1, 766; ed. 2, 526. This species is probably also a Myristica as suggested by Villar. Blanco's specimens were from Balanga, Province of Bataan, a large tree, the wood having a foetid odor. T., Banabanalo.

Helicteres apetala Blanco, ed. 1, 383; Sterculia cymbiformis Blanco, ed. 2, $526=$ Heritiera littoralis Dry.! T., Dongon, I., Paronapin.

Kleinhovia hospita Linn., Blanco, ed. 1, 652; ed. 2, 455.! T., B., Tanag, B., Hamitanag, P., Panampat, I., Bitnong. 
Dombeya decandra Blanco, ed. 1, 349; Dombeya biserrata Blanco, ed. 2, $244=$ Helicteres spicata Coleb.! 'T., Dangling aso, Buntot usa, I., Baquinbaquit.

Mimusops talosan Blanco, ed. 1, 284; ed. 2, 198. Reduced by Villar to a variety (lanigera) of the preceding and certainly only a form of the species.! Blanco's specimens were from Malinta, near Manila, a shrub flowering in September. T., Talosan.

Pterospermum hastatum Blanco, ed. 1, 526; ed. 2, 36 $\mathbf{7}=1$ 'tcrospermum diversifolium Blume.! T., Bayog.

Pterospermum obliquum Blanco, ed. 1, 529 ; Pterospermum semisagittatum Blanco, ed. 2, 368, non Buch.-Ham. A good species, the first name being the correct one.! Erroneously reduced by Villar to Pterospermum rubiginosum Hiern, a species that does not extend to the Philippines. T., Calocatingan.

Pentapetes coccinea Blanco, ed. 1, 529; Pentapetes cebuana Blanco, ed. 2, 369 = Pentapetes phoenicea Linn.!

Melochia supina Linn., Blanco, ed. 1, 524; ed. 2, $365=$ Melochia cor . chorifolia Linn.!

Geruma subtrilobata Blanco, ed. 1, 182; ed. 2, $130=$ the preceding species!

Melochia arborea Blanco, ed. 1, 524; ed. 2, $130=$ Melochia indica (Houtt.) A. Gray.! (Melochia velutina Bedd.)

Hypericum pentandrum Blanco, ed. 1,616 ; ed. $2,430=$ the preceding species!

Waltheria americana Linn., Blanco, ed. 1, 523; ed. 2, 364.! (Waltheria indica Linn.)

Abroma communis Blanco, ed. 1, 606; ed. 2, $160=$ Abroma augusta Linn.!

Abroma alata Blanco, ed. 1, 605; ed. 2, $422=$ the preceding species! This species is retained by Villar as distinct, but is certainly only a form of Abroma augusta Linn.! T., Anibong, Anibiong, V., Nabo, Labon, Anabon.

Theobroma cacao Linn., Blanco, ed. 1, 601; ed. 2, 419!

Commersonia echinata Blanco, ed. 2, $160=$ Commersonia platyphylla Andr.!

\section{TILIACE $\nexists$.}

* Triopteris poliandra Blanco, ed. 1, 380; ed. 2, 268. Reduced by Villar to Berrya ammonilla Roxb., which is certainly an error, as Blanco's description does not apply to that species. Blanco's specimens were from Angat, Province of Bulacan, and from Malinta, near Manila, a shrub, flowering in July. T., Pacpacbalang. 
* Grewia serrata Blanco, ed. 1, 444; Columbia serratifolia Blanco, ed. 2, 427, non DC. Reduced by Villar to Grewia columnaris Sm., a species not known from the Philippines. Possibly the same as Grewia multiflora Juss. Blanco's specimens were from the Tala Mountains, Province of Rizal or Bulacan.

Mallococca crenata Blanco, ed. 1, 442; Grewia multiflora? Blanco, ed. 2, 309. Reduced by Villar to Grewia umbellata Roxb., which is certainly correct.

Mallococca parva Blanco, ed. 1, 443; Grewia mallococca, Blanco, ed. 2, $310=$ Grewia multiflora Juss.! T., Danglin.

Columbia anilao Blanco, ed. 1, 554; ed. 2, $426=$ Colona serratifolia Cav.! Erroneously retained by Villar as a distinct species. T., Anilao.

Triumfetta semitriloba Linn., Blanco, ed. 1, 406; ed. 2, 283.! T., Colotan bilog.

Corchorus capsularis Linn., Blanco., ed. 1, 442; ed. 2, 308.! T., Pasao na bilog.

Corchorus catharticus Blanco, ed. 1, 442; Corchorus olitorius Linn., Blanco, ed. 2, 308. The latter name is correct.! T., Salayong.

Corchorus aestuans Blanco, ed. 1, 441; Corchorus acutangulus Linn., Blanco, ed. 2, 308. The latter name is correct.! T., Pasao na haba.

* Vallea calomala Blanco, ed. 1, 439; Ageratium calomala Blanco, ed. 2, 306. Reduced by Villar to Elaeocarpus lancaefolius Roxb., a species that does not extend to the Philippines, certainly, however, correct as to the genus. Blanco's specimens were from the Province of Batangas, flowering in August. T., Calomala.

* Elaeocarpus sylvestris Blanco, ed. 2, 306. This species is reduced by Villar to Elaeocarpus oblongus Gaertn., but Blanco's description scarcely applies to this species. Blanco's specimens were from Cebu. V., Cabilte, Cabalte.

\section{MALPHIGIACEAE.}

Hiraea reclinata Blanco, ed. 1, 378, non Jacq.; Tristillateia malintana Blanco, ed. 2, $267=$ Tristillateia australasiaca A. Rich.!

Triopteris jamaicensis Blanco, ed. 1, 379; ed. 2, 207, non Linn. = Hiptage madablota Gaertn.! V., Comimpol.

\section{ZYGOPHYLLACEAE.}

Tribulus lanuginosus Blanco, ed. 1, 350; ed. 2, 245, non Linn. = Tribulus cistoides Linn.!

\section{GERANIACEAE.}

Malva moschata Blanco, ed. 1, 551; ed. 2, 385, non Linn. A cultivated species, reduced by Villar to Pelargonium odoratissimum Ait., which is probably correct. Sp.-Fil., Malva rosa. 
Oxalis acetosella Blanco, ed. 1, 388; ed. 2, 272, non Linn. = Oxalis corniculata Linn.! T., Tangain daga, Susocoyoli. B., Daraisig. P., Malabalugbug daguis, Ayo, Cuñgi, Yayo.

Oxalis sensitiva Linn., Blanco, ed. 1, 399 ; Biophytum sensitivum DC., Blanco, ed. 2, 272. The last name is correct. T., Macahiya, Damonghiya, I., Mahahiin.

Averrhoa carambola Linn., Blanco, ed. 1, 391; ed. 2, 274.! T., Balimbin, Bilimbin.

Averrhoa bilimbi Linn., Blanco, ed. 1, 392; ed. 2, 273.! 'T., Calamias, Camias, B., Quilingiva, I., Pias.

* Averrhoa pentandra Blanco, ed. 1, 392; ed. 2, 274 . Reduced by Villar to Connaropsis as a distinct species, Connaropsis philippica F.-Vill. If correctly referred, Blanco's specific name should be retained. Blanco's specimens were from Malinta, near Manila, flowering in October.

Impatiens triflora Blanco, ed. 1, 636; ed. 2, 443, non Willd. = Impatiens balsamina Linn.! T., P., Camantigui. V., Suranga, Solanga.

\section{RUTACEAE.}

Cissus frutescens Blanco, ed. 1, 70; Cissus arborea Blanco, ed. 2, 51. Reduced by Villar to Evodia roxburghiana Benth., which is probably correct. Blanco's specimens were from the Province of Batangas, and from Malinta, near Manila. T., Matang diablo.

Melicope tetrandra Blanco, ed. 1, 293, non Roxb.; Evodia triphylla DC., Blanco, ed. 2, 50. The last name is correct.

Evodia bintoco Blanco, ed. 2, 50. Referred by Villar to Evodia latifolia DC., which is probably correct. Blanco's specimens were from Bohol and Samar, flowering in October. V., Bintoco, Tancapan.

* Orixa ternata Blanco, ed. 1, 62; ed. 2, 45. Reduced by Villar to Evodia robusta Hook. f., a species that is unknown from the Philippines, probably, however, correct as to the genus. A slirub flowering in July.

* Fagara octandra Blanco, ed. 1, 67; ed. 2, 47. Reduced by Villar to Melicope ternata Forst., a species that certainly does not extend to the Philippines. Blanco's specimens were from San Mateo, Province of Rizal, flowering in June. T., Matang arao.

" Fagara piperita Blanco, ed. 1, 64; ed. 2, 47, non Linn. Reduced by Villar to Zanthoxylum oxyphyllum Edgw., a species that certainly does not extend to the Philippines. Correct as to the genus and probably identical with Zanthoxylum piperatum DC. T., Cayutana.

Fagara pterota Blanco, ed. 1, 66; ed. 2, 47, non Linn. Referred by Villar to Zanthoxylum avicenna DC., which is probably correct. P., T., Cayutana, V., Salay marbar, Baga tambal, P., Salay cangay.

Lunasia amara Blanco, ed. 1, 783; Pilocarpus amara Blanco, ed. 2, 540. The first name is correct, the type of the genus Lunasia, one of the few valid genera established by Blanco. T., Lunas. 
* Bergera compressa Blanco, ed. 1, 360; ed. 2, 254. Reduced by Villar to Clausena villdenovii W. et A., a species that does not extend to the Philippines. Probably, however, correct as to the genus. A small tree flowering in August. T., Piris.

* Bergera inodora Blanco, ed. 1, 361; Bergera koenigii Blanco, ed. 2, 254, non Linn. Reduced by Villar to Clausena indica Oliv., a species that does not extend to the Philippines, probably, however, correct as to the genus. Blanco's specimens were from Malinta, near Manila.

Limonia linearis Blanco, ed. 1, 357; Limonia monophylla Linn., Blanco, ed. 2, $252=$ Atalantia monophylla (Linn.) Correa. ? T., Dayap na monti.

Limonia disticha Blanco, ed. 1, 356; Liṃonia corymbosa Blanco, ed. 2, 251 = Atalantia disticha (Blanco) (Atalantia nitida Oliv., Journ. Linn. Soc. 5, Suppl. 2:25. 1861.) Blanco's name is the oldest for this species and slould be retained. Erroneously referred by Villar to Atalantia racemosa W. et A., a species that does not extend to the Philippines. T., Malarayap.

Limonia trifoliata Linn., Blanco, ed. 1, 357; ed. 2, $252=$ Triphasia 'trifoliata (Linn.) DC.! T., Limoncitos.

Melicope conferta Blanco, ed. 2, 205. Reduced by Villar to Acronychia laurifolia Blume, which is probably correct.

Murraya cerassiformis Blanco, ed. 1, 363; Murraya exotica Blanco, ed. 2, 255, non Linn. = Glycosmis pentaphylla Correa.! T., Guinguen.

Murraya lobata Blanco, ed. 1, 363; ed. 2, 256. Reduced by Villar to a variety of Glycosmis pentaphylla Correa, which is certainly correct.

* Bergera ternata Blanco, ed. 1, 360; ed. 2, 254. Reduced by Villar to Glycosmis bilocularis Thwaites, a species that does not extend to the Philippines. Probably correct as to the genus, and a form of Glycosmis pentaphylla Correa. Blanco's specimens were from Tala, Province of Rizal or Bulacan, a shrub with fragrant fruits. T., Malamolauin.

Andromeda japonica Blanco, ed. 1, 371; ed. 2, 261, non Thunb. = Micromelum tephrocarpum Turcz.! Erroneously referred by Villar to Micromelum glabrescens Benth., a species that does not extend to the Philippines. T., Tulibas.

Connarus foetens Blanco, ed. 1, 525; Connarus santaloides Blanco, ed. 2, 366 = Murraya exotica Linn.! T., Camuning, Molavin. V., P., Camunin, Banati.

Cookia anisum olens Blanco, ed. 1, 359; Cookia anisodora Blanco, ed. 2, 253 = Clausena anisum olens (Blanco) Merrill, Govt. Lab. 17:21. 1904. T., Maisipaisi, Calomata, Camanguianis.

Cookia wampi Blanco, ed. 1, 358; ed. 2, $253=$ Clausena wampi (Blanco) Oliver.! T., Huampit.

Citrus notissima Blanco, ed. 607; ed. 2, 424. Reduced by Villar to Citrus medica Linn., var. acida Hook. f., which may be correct. T., Dayap. Sp.-Fil., Limoncito. 
* Citrus mitis Blanco, ed. 1, 610; ed. 2, 426. Reduced by Villar to Citrus medica Linn., var. limetta Hook. f., but Blanco's deseription does not apply to this variety. A small spineless shrub. T., Aldonises, Calamondin.

Citrus reticulata Blanco, ed. 1, 610; ed. 2, $424=$ Citrus aurantium Linn.! T., Sintonis. Sp.-Fil., Narangitas.

Citrus aurantium Blanco, ed. 1, 609; ed. 2, 425, non Linn. Reduced by Villar to Citrus aurantium Linn., var. bigrardia Hook. f., but Blanco's description does not agree with that of this variety. A form or variety of Citrus aurantium Linn.! T., Dalandan, Cahil.

Citrus papillaris Blanco, ed. 1, 610; ed. 2, 425. Reduced by Villar to Citrus aurantium Linn., var. bergamina Hook. f., which is certainly an error. Certainly a form or variety of Citrus aurantium Linn.! T., Pisong.

Citrus torosa Blanco, ed. 1, 609; ed. 2, 425. Reduced by Villar to Citrus hystrix DC., which is probably correct. T., Suya, Colobot.

Citrus decumana Linn., Blanco, ed. 1, 606; ed. 2, 424.! T., Lucban, Suha.

Murraya odorata Blanco, ed. 2, 256. Reduced by Villar to Feronia elephantum Correa, which is probably correct. Blanco's specimens were from Angat, Province of Bulacan, flowering in February.

Limonia glutinosa Blanco, ed. 1, 358; Feronia ternata Blanco, ed. 2, $252=$ Aegle glutinosa (Blanco) Merrill, Govt. Lab. 6: 12.1904. (Aegle decandra Naves.) T., Malacabuyao. P., T., Tabog.

\section{SIMARUBACEAE.}

Manungala pendula Blanco, ed. 1, 306; Niota tetrapetala Lam., Blanco, ed. 2, 213 = Samadera indica Gaertn.! T., V., P., B., Manungal V., Linatong anac, Linton gamai, Palagium, Palagarium, Ponoan, Mavindato, Daraput.

Paliurus perforatus Blanco, ed. 1, 174; ed. 2, $122=$ Harrisonia brownii A. Juss.! T., Asimao.

Paliurus dubius Blanco, ed. 1, 175; ed. 2, 122. Reduced by Villar to Harrisonia bennetii Hook. f., var. multijuga F.-Vill. Probably identical with $H$. bennetii Hook. f. T., Laiya.

Ailanthus pongelion Blanco, ed. 1, 380; ed. 2, 268. Reduced by Villar to Ailanthus malabarica DC., which is certainly correct.! T., Macaisa, Balocas.

\section{OCHNACEAE.}

Ochna fascicularis Blanco, ed. 2, 246.! A good species. Erroneously reduced by Villar to Brackenridgea. T., Aniatan. 


\section{BURSERACEA.}

Guiacum abilo Blanco, ed. 1, 364; Icica abilo Blanco, ed. 2, $256=$ Garuga floribunda Decne.! Villar reduces the species as described in the first edition to Garuga pinnata Roxb., and the species as described in the second edition to Garuga foribunda Decne., although Blanco's descriptions manifestly apply to the same species. T., Abilo.

Canarium album Blanco, ed. 1, 793; ed. 2, 546, non Raeusch $=$ Canarium luzonicum Miq.! (Canarium carapifolium Perk.) Erroneously reduced by Villar to Canarium commune Linn., a closely related species. The source of Manila Elemi.! T., Pisa, Pilani. I., Anten.

Canarium commune Blanco, ed. 1, 791, non Linn.; Canarium pimela Blanco, ed. 2, 545, non Koen. = Canarium villosum (Miq.) F.-Vill. (Canariopsis villosa Miq.; Canarium cumingii Engler.!) P., Palsahinhin, Anagatli, Anagalti. I., Anten.

Boswellia ? obliqua Blanco, ed. 2, 243 (err. typ., oblicua) = GANoPHyLLUM OBLIQUUM (Blanco) (Ganophyllum falcatum Blume.!) Blanco's name is the earliest one published for this species and should be retained. It is described in the first edition under the native name only, Pandapanda.

* Boswellia ? integra Blanco, ed. 2, 242. Referred by Villar to Protium javanicum Burm., but as no species of this genus is at present known from the Philippines Villar's identification must be considered doubtful. This species is described in the first edition under the native name Calamansalai. Blanco's specimens were from the mountains near San Mateo, Province of Rizal, a tree fruiting in June. T., Polyagan.

\section{MELIACEAE.}

Plagianthus humilis Blanco, ed. 1, 526; ed. 2, $366=$ TurraeA Humilis (Blanco) (Turraea pumila Benn. Pl. Jav. Rar. 183. 1840.) Blanco's name is the earliest for this species and should be retained.

Melia azedarach Blanco, ed. 1, 345, non Linn.; Melia composita Blanco, ed. 2, 241, non Willd. = Melia candollei Juss.! Erroneously reduced by Villar to Melia dubia Cav., a species that does not extend to the Philippines. T., Malongain.

Turraea decandra Blanco, ed. 1, 347; Turraea virens Blanco, ed. 2, 243 , non Linn. = Drsoxylox DecANDRum (Blanco) (Dysoxylon blancoi Vidal, Cat. Pl. Prov. Manila, 22; Sinopsis, Atlas, t. 39. f. A.; D. salutare F.-Vill.; D. amooroides Miq.) DeCandolle ${ }^{1}$ retains Blanco's Turraea virens and $T$. decandra as distinct, uncertain species, but it is evident, however, that the two descriptions apply to the same species, as noted by Villar. This species is represented by Nos. 141, 2140, 2758, and 2776 Merrill, the two former numbers having been identified by Perkins $^{2}$ as Dysoxylon amooroides Miq. P., Iguiu, Aguiu, Taclitan, Malabangao. B., Ananangtang, Mananantang, Bacugan, Mocasisi, Bingliu, Palohambobocag, Bolong tambal. I., Pasiloag.

${ }^{1}$ Monog. Phan. 1: 749.

${ }^{2}$ Frag. Fl. Filip. 31. 1904. 
Trichilia pentandra Blanco, ed. 1., 355; ed. 2, 249. = CHISocheton PeNTANDRUM (Blanco) (C. philippinum Harms; C. ceramicus F.-Vill., non Miq.) T., Salaqui, Agapanga.

* Turraea octandra Blanco, ed. 1, 349; ed. 2, 244. Reduced by Villar to Dysoxylon schizochitode (Turcz.) DC., which may possibly be correct, in which case Blanco's name should be retained. A tree flowering in August. 'T., Himamao.

Sandoricum ternatum Blanco, ed. 1, 346; Sandoricum indicum Cav., Blanco, ed. 2, 242. The last name is correct.! T., Santol.

* Trichilia tripetala Blanco, ed. 1, 354; ed. 2, 248. Reduced by Villar to Amoora rohituka W. et A., a species not known from the Philippines. Probably correct as to the genus although excluded from the Meliacea by DeCandolle.

Lansium domesticum Jack, Blanco, ed. 2, 228.! This species is described in the first edition under the native name Lansones. T., Lansone. V., Bulahan, Boocan, Boboa.

* Portesia rimosa Blanco, ed. 1, 297; Trichilia rimosa Blanco, ed. 2, 250. Reduced by Villar to Amoora canarana Hiern. Probably correct as to the genus, but the species does not extend to the Philippines. Blanco's specimens were from the Province of Batangas, a tree flowering in May. 'T., Busilac.

* Trichilia ? volubilis Blanco, ed. 2, 249. Reduced by Villar to Aglaia grandis Miq., a species not known from the Philippines. Excluded from the Meliacea by DeCandolle, which is probably correct. A vine flowering in January. T., Gogong toco, Cubatili, Gogong bisaya.

* Argophyllum pinnatum Blanco, ed. 1, 186; ed. 2, 131. Reduced by Villar to Aglaia angustifolia Miq., a species that does not extend to the Philippines, probably, however, correct as to the genus. Blanco's specimens were from Angat, Province of Bulacan, a shrub flowering in March.

Melia iloilo Blanco, ed. 2, $241=$ Aglaia argentea Blume! Described in the first edition under the native name only. P., Iloilo.

Xylocarpus granatum Koenig., Blanco, ed. 1, 298; ed. 2, 207.! T., Tabigui, Nigui, Calumpang sa lati. P., Migi.

* Cedrela odorata Blanco, ed. 1, 184; ed. 2, 130, non Linn. Reduced by Villar to Cedrella toona Roxb., a species not known from the Philippines. Correct as to the genus. T., P., Calantas. B., Lanigpa, Lanigda.

* Cedrela taratara Blanco, ed. 2, 131. A species known only from Blanco's description, whose specimens were from Bohol. T., Taratara. V., Sandana. B., Bolongcauit. 


\section{CHAILLE'TIACEAE.}

* Elaeocarpus ? integrifolius Blanco, ed. 2, 306. Reduced by Villar to Chailletia gelonioides Hook. f., which must be considered doubtful, as this species has not been found in the Philippines. Described in the first edition under the native name, Bitlag. A tree flowering in March.

* Quilesia sericea Blanco, ed. 1, 177; ed. 2, 125. Reduced by Villar to Chailletia griffithii Hook. f., a species not known from the Philippines, and which must accordingly be considered doubtful. A shrub found in Ilocos Province, flowering in January. I., Decdec.

* Riana tricapsularis Blanco, ed. 1, 850; ed. 2, 126. Reduced by Villar to Chailletia helferiana Kurz, a species that certainly does not extend to the Philippines. A small shrub flowering in July. Blanco's specimens were from Angat, Province of Bulacan, no native name given.

\section{OLACACEAE.}

Fissilia psittacorum Blanco, ed. 1, 28; ed. 2, 20, non Lam. = Olax imbricata Roxb.! T., Malabaguio, I., Tadiag.

\section{CELASTRACEAE.}

Diosma serrata Blanco, ed. 1, 168; ed. 2, $119=$ Celastrus paniculata Willd.! T., Bilogo.

Cupania spinosa Blanco, ed. 1, 184; ed. 2, $204=$ Gymnosporia montana Roxb.! T., Malarayap.

* Hippocratea volubilis Blanco, ed. 1, 27; ed. 2, 20. Reduced by Villar to Hippocratea obtusifolia Roxb., a species as yet not collected in the Philippines. Probably Hippocratea indica Willd. T., T'atlong.

Salacia sinensis Blanco, ed. 1, 26; ed. 2, 19. Reduced by Villar to Salacia prinoides DC., which is probably correct. 'T., Matang olang.

* Comocladia serrata Blanco, ed. 1, 30. Reduced by Villar to Salacia oblonga Wall., a species that certainly does not extend to the Philippines. Blanco does not include this species in the second edition. Blanco's specimens were from the seashore at Batangas, flowering in February, no native name given.

\section{RHAMNACEAE.}

Enrilia dichotoma Blanco, ed. 1, 709; Ventilago monoica Blanco, ed. 2, 124 = Ventilago Dichotoma (Blanco) (Ventilago luzonensis Vidal, Rev. Pl. Vasc. Filip. 90. 1886.) Villar erroneously reduces this species to Ventilago maderaspatana Gaertn. T., Salapao, Silipao.

Rhamnus jujuba Linn., Blanco, ed. 1, 172; Zizyphus jujuba (Linn.) Lam., Blanco, ed. 2, 120. The last name is correct. Sp.-Fil., Manzanitas. 
Rhamnus zizyphus Blanco, ed. 1, 171, non Linn.; Zizyphus lotus Blanco, ed. 2, 121, non Lam. = Zizyphus trinervis Poir.! Erroneously reduced by Villar to Zizyphus oenoplia Mill. T., Duclap, Talanai. I., Labba labba, Lanoti.

* Rhamnus talanai Blanco, ed. 1, 170; Zizyphus latifolia Blanco, ed. 2, 121, non Poir. Reduced by Villar to Zizyphus oenoplia Mill., which is certainly an error. Possibly a form of Zizyphus trinervis Poir. Blanco's specimens were from San Mateo, Province of Rizal. T., Talinas.

Rhamnus zonulatus Blanco, ed. $1,172=$ Zizyphus zonulatus Blanco, ed. 2, 120.! (Zizyphus arborea Merrill, Govt. Lab. 1: 11. 1904.!) Blanco's second name is the correct one for this species, which was erroneously referred by Villar. to Zizyphus xylopyrus Willd. T., Balacat.

* Rhamnus dalanta Blanco, ed. 1, 170 = Zizyphus dalanta Blanco, ed. 2, 121. Probably a distinct species. Blanco's specimens were from Bonbonon, Negros. V., Dalanta.

Rhamnus carolinianus Blanco, ed. 1,169 ; ed. 2, 119, non Walt. $=$ Colubrina asiatica L. C. Rich.! Erroneously reduced by Villar to Rhamnus wightii Wight et Arn., a species that certainly does not extend to the Philippines. T., Cabatiti.

Gouania domingensis Blanco, ed. 1, 196; ed. 2, 138, non Linn. = Gouania leptostachya DC.!

\section{AMPELIDACE $巴$.}

Cissus quadrangularis Linn., Blanco, ed. 1, 72; ed. 2, 52.!

* Cissus vesicatoria Blanco, ed. 12, 50. Reduced by Villar to Cissus (Vitis) repens W. et A., which may possibly be correct. T., Pirapit angin.

Cissus latifolia Blanco, ed. 2, 52, non Lam.; Cissus simplex Blanco, ed. 1, 72. Reduced by Villar to Cissus (Vitis) adnata, which is probably correct.

Cissus acida Blanco, ed. 1, 69; ed. 2, 50, non Linn. = Cissus carnosa Lam.!' T., Calitcalit, Cavilan, Pacopol. B., Lupo, Langingi, Lagini, Raguindi, P., Culutpamo.

Cissus rubescens Blanco, ed. 1, 71; Cissus alata ? Blanco, ed. 2, 51, non Jacq. Reduced by Villar to Cissus geniculata Roxb., which may be correct. T., Sampang. P., Loba.

* Cissus pedata Blanco, ed. 1, 71; ed. 2, 52, non Lam. Reduced by Villar to Vitis capriolata Don., which is probably an error, as this species does not extend to the Philippines. T., Ayo.

Aquilicia sambucina Blanco, ed. 1, 178, non Linn.; Leea sambucina Blanco, ed. 2, 126, non Blume $=$ Leea rubra Blume.! T., Caliantang, Abangabang.

$21896-3$ 
Ticoria aculeata Blanco, ed. 1, 85; Leea aculeata Blume, Blanco, ed 2, 127. The latter name is correct.! P., Malimali.

\section{SAPINDACEAE.}

Cardiospermum halicacabum Blanco, ed. 1, 312; ed. 2, $218=$ Cardiosper . mum halicacabum Linn., var. microcarpum Blume.! T., Bangcolon.

* Sapindus koelreuteria Blanco, ed. 1, 289; Koelreuteria arborea Blanco, ed. 2, 202. Reduced by Villar to Hemigyrosa perrottetii Blume = Guioa perrottetii Radlk., which is certainly an error. Blanco gives no native name, and no locality.

Molinaea arborea Blanco, ed. 1, 292; ed. 2, $204=$ Guioa perrottetii (Blume) Radlk.! Erroneously reduced by Villar to Hemigyrosa canescens Thw., a species that does not extend to the Philippines. Blanco's specimens were from Batangas, and also from Parañaque, near Manila, flowering in January. T., Salab.

Quassia tricarpa Blanco, ed. 1, 351; ed. 2, 246. Reduced by Villar to Sapindus saponaria Linn., and is certainly the form described by Radlkofer as Sapindus saponaria Linn., forma microcarpus, also probably identical with the form described by Vidal as Sapindus turczaninowii. T., Tiquis tiquis, Catiquis, Sausanli, I., Cusiben, P., Malapalitpit.

Sapindus saponaria Blanco, ed. 1, 292, non Linn.; Sapindus guisian Blanco, ed. 2, 201 = Sapindus rarak DC. (Dittelasma rarak Hook. f.) A tree flowering in April, no herbarium specimens known from the Philippines at the present time. T., Guisan, V., Duca.

Sapindus edulis Blume, Blanco, ed. 2, $201=$ Erioglossum rubiginosum Blume.!

* Schmidelia conferta Blanco, ed. 2, 217. Reduced by Villar to Allophy. lus zeylanicus Linn., a species that does not extend to the Philippines. Blanco's specimens were from Angat, Province of Bulacan, possibly not a species of Sapindacea.

Aporetica ternata Blanco, ed. 1, 290, non Forst. Aporetica gemella Blanco, ed. 2, 203, non DC. = Allophylus grossedentata (Turcz.) Radlk.! Erroneously reduced by Villar to Allophylus cobbe Blume.

* Aporetica penicellata Blanco, ed. 1, 291; ed. 2, 203. Reduced by Villar to Allophylus cobbe Blume, var. villosa, which is certainly an error, although certainly correct as to the genus.

* Quassia simaruba Blanco, ed. 2, 247, non Linn. Reduced by Villar to Cupania glabrata Kurz., a species that does not extend to the Philippines. Blanco's specimens were from Angat, Province of Bulacan, fruiting in February.

* Euphoria annularis Blanco, ed. 1, 285; ed. 2, 199. Reduced by Villar to Ratonia litoralis Benth. et Hook. f., which is certainly an error. It may be identical with Lepidopetalum perrottetii Blume. A tree flowering in August. T., Guisian, Guisihan. 
Euphoria cubili Blanco, ed. 1, 28i; ed. 2, 200 = Cubilia blancoi Blume.! Reduced by Villar to Cubilia rumphii Blume, which is a synonym of C. blancoi.! See Icon. Bogor. 1, part 4, 51, tt. 92, 93. 1901. This species is represented by No. 445 Forestry Bureau, and No. 33 Decades Philippine Forest Flora. T., Cubili, Lubilubi.

* Sapindus baccatus Blanco, ed. 1, 290; Koelreuteria edulis Blanco, ed. 2, 202. Blume transferred this species to Otophora, under the name Otophora blancoi. The species is known only from Blanco's description, his material being from the Provinces of Pampanga and Pangasinan, a tree flowering in December. P., Talinouno. I., Dirig.

Capura pinnata Blanco, ed. 1, 264; Capura purpurata Blanco, ed. 2, $184=$ Otophora fruticosa Blume.! (O. nigrescens Vill.; 0 . pinnata Merrill.) Erroneously reduced by Villar to Otophora paucijuga Hiern, a species that does not extend to the Philippines.

* Ornitrophe triandra Blanco, ed. 1, 291; Schmidelia triandra Blanco, ed. 2, 218. Reduced by Villar to Schleichera trijuga Willd., which is very doubtful. Blanco gives no native name, and no locality.

*Euphoria didyma Blanco, ed. 1, 288; ed. 2, 201. Referred by Villar to Nephelium glabrum Noronh., which is possibly correct. T., Guisian, Guisihan, Tinaingui.

Euphoria litchi Blanco, ed. 1, 285; ed. 2, 199, non Juss. =Euphoria cinerea Radlk.! T., Alpai, Lechias, Alipai, Alupai. B., Boboa.

Ptelia arborea Blanco, ed. 1, 63; Seringia lanceolata Blanco, ed. 2, 45= Harpullia arborea (Blanco) Radlk.! Erroneously reduced by Villar to Harpullia cupanioides Roxb. T., Poas. I., Oas.

Melicocca triptera Blanco, ed. 2, $203=$ Tristira triptera (Blanco) Radlk.!

Dodonæa angustifolia Linn. f., Blanco, ed. 1, 312; ed. 2, $217=$ Dodoncea viscosa Linn. var. vulgaris Benth.! T., Calapinai.

\section{ANACARDIACEAE.}

Mangifera indica Linn., Blanco, ed. 1, 179; ed. 2, 127.! T., Manga.

Mangifera rostrata Blanco, ed. 2, 129. Reduced by Villar to Mangifera silvatica Roxb., which is probably an error, as Blanco's species appears to be only a form of the common Mangifera indica Linn. Sp.Fil., Manga-pico.

Mangifera altissima Blanco, ed. 1, 181; ed. 2, 129.! Reduced by Villar to Mangifera longipes, a species not as yet discovered in the Philippines. A distinct species related to Mangifera quadrifida Jack. See Merrill, Govt. Lab. Publ. 17: 27. 1904. T., Pajo, Pao.

- Mangifera anisodora Blanco, ed. 2, 129. Reduced by Villar to Mangifera macrocarpa Blume ( $\boldsymbol{M}$. fragrans Maingay.). This may be a distinct species, or a form of Mangifera indica Linn. Blanco saw no specimens, but established his species on hearsay. His information was from the pueblo of Sinait, Province of Ilocos Norte. Sp.-Fil, Manga de anis. 
* Mangifera pinnata Blanco, ed. 1, 182, non Lam. This species is not included in the second edition, and is certainly not a Mangifera. It may be a species of some other genus of Anacardiacece, or may be a species of the Meliacex. T., Tagapi.

Cassuvium reniforme Blanco, ed. 1, 322; ed. 2, $227=$ Anacardium occidentale Linn.! T., Casoy. I., Bollugo.

Fagara decandra Blanco, ed. 1, 66; ed. 2, 48=Buchanania forida Schauer. var. arborea Engl.! T., Balinhasa.

Helicteres pinnata Blanco, ed. 1, 384; Crytocarpa quinquestila Blanco, ed. 2, $269=$ Koordersiodendron pinnatum (Blanco) Merrill, Forestry Bureau, Bull. 1:33. 1903. (K. celebicum Engl.) T., Amoguis.

Semecarpus cuneiformis Blanco, ed. 1, 220; ed. 2, 155. Apparently a form or variety of Semecarpus perrottetii March.! T., Ligas.

Semecarpus anacardium Blanco, ed. 1, 217; ed. 2, 152, non Linn. f. $=$ Semecarpus perrottetii March.! Erroneously reduced by Villar to Semecarpus pubescens Thw. T., Ligas. I., Camiring. V., Langas.

Spondias dulcis Blanco, ed. 1, 390; ed. 2, 273, non Forst. = Spondias lutea Linn.! Erroneously reduced by Villar to Spondias purpurea Linn. Sp.Fil., Sirihuelas.

Poupartia pinnata Blanco, ed. 1, 392; ed. 2, 275 = Spondias mangifera Willd.! T., B., Dao.

Paliurus edulis Blanco, ed. 1, 173; Paliurus lamio, Blanco, ed. 2, 122 = Dracontomelum cumingianum Baill.! Although Blanco's name is the earlier, Baillon's should be retained, as Blanco in establishing the species describes the flowers (and leaves?) of some species of Canarium, while the rest of his description applies to Dracontomelum. Blanco undoubtedly intended to describe the species known to-day as Dracontomelum cumingianum, as that species is universally known by the Tagalogs by the name of Lamio. T., Lamio, Malaiyo. V., Batoan.

Paliurus dao Blanco, ed. 1, 174; ed. 2, 122=Dracontemelum mangiferum Blume.! T., Dao.

\section{MORINGACEAE.}

Moringa oleifera Lam., Blanco, ed. 1, 341; ed. 2, 238.! T., Malungay, Camalungai, Calungai. V., P., Malungai, Calungai, Dool, Malungit.

\section{CONNARACEAE.}

Cnestis volubilis Blanco, ed. 1, 385; Cnestis trifolia Blanco, ed. 2, 270 , non Lam. $=$ RoureA volubilis (Blanco) $\quad$ Rourea heterophylla Planch.) Blanco's name is the earlier, and should be retained. T., Camagsa taquilis, Palo Santo, Guicos guicos. V., P., Hanambabao, Ungalina mapula, Magtabig, Mavindato.

Cnestis diffusa Blanco, ed. 1 ; Cnestis polyphylla Blanco, ed. 2, $270=$ Cnestis ramiflora Griff.! Erroneously reduced by Villar to Rourea rugosa Planch. T., Ibaiban. 
* Cnestis erecta Blanco, ed. 1, 387; Omphalobium plctum Blanco, ed. 2, 271. Reduced by Villar to Connarus monocarpus Linn., a species which certainly does not extend to the Philippines. Possibly a distinct species. A small shrub, flowering in October, no native name given.

* Cnestis corniculata Blanco, ed. 1, 386; ed. 2, 270, non Lam. Reduced by Villar to Connarus ferrugineus .Jack., which is certainly an error. Blanco's specimens were from the pueblo of Tagudin, Province of Ilocos Sur. I., Sal-laday.

Cnestis glabra Blanco, ed. 1, 387; ed. 2, 271, non Lam. Reduced by Villar to Connarus paniculatus Roxb., a species that certainly does not extend to the Philippines. Certainly a synonym of Rourea multiflora Planch.! No locality or native name given.

\section{LEGUMINOSAE.}

Crotalaria linifolia Linn. f., Blanco, ed. 1, 570; Quirosia secunda Blanco, ed. 2, 398. The former name is correct.

Crotalaria pallida Blanco, ed. 1, 570, non Ait.; Crotalaria pumila Blanco, ed. 2, 397, non Schrank = Crotalaria sessiliflora Linn.!

Phaseolus bulai Blanco, ed. 1, 572; Quirosia anceps Blanco, ed. 2, $398=$ Crotalaria verrucosa Linn.! T., Bulai lava.

Crotalaria quinquefolia Linn., Blanco, ed. 1, 569; ed. 2, 397.! T., Catanda, Susoi, Susosusoyan, Balatong aso.

* Liparia badocana Blanco, ed. 1, 597 ; Psoralea badocana Blanco, ed. 2, 416. Retained by Villar as a distinct species under the second name, which may be correct, citing Meladenia densiflora Turcz., as a synonym. Blanco's specimens were from the pueblo of Badoc, Ilocos Province. No native name given.

Amorpha glandulosa Blanco, ed. 1, 555; Dalea alopecuróides Blanco, ed. 2, 389, non Willd. = Dalea glandulosa (Blanco) (Dalea nigra Mart. et Gal.). Although this plant is a native of America, yet the earliest description is that of Blanco, and his name should be retained. T., Durang parang, Camangi.

Indigofera angustifolia Blanco, ed. 1, 596; ed. 2, 415, non Linn. = Indigofera hirsuta Linn.! I., Tayomtayom.

Indigofera argentea Blanco, ed. 2, 415, non Linn. = Indigofera tinctoria Linn.!

Indigofera tinctoria Blanco ed. 1, 591; ed. 2, 413, non Linn. = Indigofera anil Linn.! T., Tayom. P., Tayung. V., Tagung.

Indigofera hirsuta Blanco, ed. 1, 591; non Linn.; Indigofera senegalensis Blanco, ed. 2, 412, non Lam. = Tephrosia purpurea Pers.! T., Tayomtayoman. V., Dagangdang. P., Maasic.

Cylista piscatoria Blanco, ed. 1, 589; Galactia ? terminiflora Blanco, ed. $2,411=$ Millettia PIscatoria (Blanco). Erroneously reduced by Villar to Milletia splendens W. et A., a species that certainly does not extend to the Philippines. T., Tubli. 
Galedupa pungam Blanco, ed. 1, 558; ed. 2, 390, non Gmel. = Gliricidia sepium (Jacq.) Steud.! (G. maculata H. B. K.) Sp.-Fil., Madre cacao.

Coronilla emerus Blanco, ed. 1, 582, non Linn.; Sesbania cannabina Blanco, ed. 2, 418. Reduced by Villar to Sesbania aculeata, var. paludosa Baker, which is probably correct. T., Malacaguois.

Sesbania grandiflora Pers., Blanco, ed. 1, 599; ed. 2, 418.! T., Caturai. Lupinus angustifolius Blanco, ed. 1, 566, non Linn.; Smithia bigeminata Blanco, ed. 2, 395. Reduced by Villar to Zornia diphylla Pers., which is probably correct.

Arachia hypogaea Linn., Blanco, ed. 1, 567; ed. 2, 396.! T., Mani.

Hedysarum vespertilionis Linn., Blanco, ed. 1, 581; ed. 2, $407=$ Lourea vespertilionis (Linn.) Desv.

Tetragonolobus simplicifolius Blanco, ed. 397. This species was reduced by Villar to Alyscicarpus tetragonolobus Edgw., a species that certainly does not extend to the Philippines. It is undoubtedly identical with Alyscicarpus bupleurifolius DC. Blanco's specimens were from Parañaque, near Manila.

Aeschynomene arborea Blanco, ed. 1, 581; ed. 2, $406=$ Desmodium umbellatum (Linn.) DC.!

Cytisus quinquepetalus Blanco, ed. 1, 598; Cajanus quinquepetalus Blanco, ed. 2, 417. Reduced by Villar to Desmodium cephalotes Wall., which is probably correct.

Hedysarum pulchellum Linn., Blanco, ed. 1, 581; Dicerma pulchellum DC., Blanco, ed. 2, $407=$ Desmodium pulchellum (Linn.) Benth.! T., Payangpayang. V., Calaicai.

Hippocrepis rhomboidea Blanco, ed. 1, 585; Desmodium spirale DC., Blanco, ed. 2, 408. The latter name is correct.

Hippocrepis comosa Blanco, ed. 1, 584, non Linn.; Desmodium diversifolium Blanco, ed. 2, 408, non DC. = Desmodium gangeticum DC.! T., Manquit.

Hippocrepis multisiliquosa Blanco, ed. 1, 584, non Linn.; Desmodium gangeticum Blanco, ed. 2, 408, non DC. = Desmodium latifolium DC.! T., Manquit.

Hippocrepis humilis Blanco, ed. 1, 585; Desmodium parvifolium Blanco, ed. 2, 408, non DC. = Desmodium triflorum DC.! T., Pacpac langao.

Abrus precatorius Linn., Blanco, ed. 1, 565; ed. 2, 394.! T., Saga, Sagamamin, Bangati. B., Bangati, Gicos gicos, Agaiyangyiang, Mlanga dolong, Caloo, Matangpune, Aroyangyang. P., Cansasaga. I., Bugayon.

Negretia urens Blanco, ed. 1, 586; ed. 2, $409=$ Muguna imbricata DC.! (No. 3783 Merrill.) Erroneously reduced by Villar to Mucuna monosperma DC., a species that certainly does not extend to the Philippines. A vine, flowering in November. T., Buquiquit, Lipai.

Negretia pruriens Blanco, ed. 2, 411. Reduced by Villar to Mucuna atropurpurea DC., which may be correct. V., Nipai, Lipai. 
Negretia mitis Blanco, ed. 1, 588; ed. 2, 410, non Beauv. Reduced by Villar to Mucuna nivea DC., but probably only a form of Mucuna pruriens DC. T., Garbanzos, Habas.

Erythrina carnea Blanco, ed. 1, 564; ed. 2, 393, non Ait. = Erythrina indica Lam.! T., B., P., Dapdap. T., Casindac, B., Cabrab. P., Sulbang.

Erythrina picta Blanco, ed. 1, 565, non Linn.; Erythrina caffra Blanco, ed. 2, 394, non Thunb. = Erythrina ovalifolia Roxb.! T., Anii.

Dolichos ensiformis Linn., Blanco, ed. 1, 577 ; Canavalia gladiata Blanco, ed. 2, $403=$ Canavalia ensiformis (Linn.) DC.! T., Habas. V., Magtambocao.

Dolichos acinaciformis 13lanco, ed. 1, 578, non Jacq.; Canavalia ensiformis Blanco, ed. 2, 404, non. DC. = Canavalia obtusifolia Cav.! T., Pataning dagat.

Dioscorea bolojonica Blanco, ed. 1, 800; ed. 2, 551; Pachyrhizus teres Blanco, ed. 1, 580; Pachyrhizus montanus Blanco, ed. 2, $406=$ Pueraria phaseoloides (Roxb.) Benth.! Villar probably correctly reduces Dioscorea bolojonica Blanco to Pueraria, Blanco having described that species from leaf specimens only. The native name given by Blanco for his Dioscorea is Bahai., for Pachyrhizus, Sincamas aso.

Phaseolus inamoenus Blanco, ed. 1, 571; ed. 2, 399, non ? Linn. = Phaseolus vulgaris Linn.! This is reduced by Villar to a variety of Phaseolus lunatus Linn. T., Patani.

* Phaseolus ilocanus Blanco, ed. 1, 572; Phaseolus tunkinensis Blanco, ed. 2, 399, non ? Lour. Reduced by Villar to a variety of Phaseolus lunatus Linn., probably only a cultivated form of this species. Sp.-Fil., Frijoles del Abra.

* Phaseolus vexillatus Blanco, ed. 1, 574, non Linn.; Phaseolus vulgaris Blanco, ed. 2, 401, non Linn. Reduced by Villar to a variety of Phaseolus lunatus Linn., which may be correct. Much cultivated in the Province of Batangas. T., Buttingi, Biringi.

* Phaseolus caracalla Linn., Blanco, ed. 1, 575; ed. 2, 401. Retained under this name by Villar; doubtful. T., Sitao.

Phaseolus mungo Linn., Blanco, ed. 1, 573; ed. 2, 400.! T., Balatong, Mongos.

* Dolichos trilobus Blanco, ed. 2, 403, non Linn. Reduced by Villar to Phaseolus calcaratus Roxb., which may be correct. Blanco's specimens were from Guadalupe, near Manila, flowering in January.

Phaseolus lunatus Linn., Blanco, ed. 1, 573; ed. 2, 400.! T., Zabache.

* Dolichos repens Blanco, ed. 1, 577; ed. 2, 402, non Linn. Reduced by Villar to Vigna repens Baker, which is certainly an error, as the latter species does not extend to the Philippines. Blanco's specimens were from Batangas, flowering in August. No native name given. 
Dolichos sesquipedalis Blanco, ed. 2, 402, non Linn.; Dolichos echinulatus Blanco, ed. 2, 401 = Vigna catjang Endl.! T., Quibal, Sitao.

Pachyrhizus jicamas Blanco, ed. 1, 579; Pachyrhizus angulatus Rich., Blanco, ed. 2, 405. The latter name is correct. T., Sincamas, Hicamas.

Clitorea ternatea Linn., Blanco, ed. 1, 590; ed. 2, 412.! T., Colocanting.

Glycine lucida Blanco, ed. 1, 578, non Forst.; Lablab cultratus DC., Blanco, ed. 2, $405=$ Dolichos lablab Linn.! T., Bulai, Batao.

Dolichos tetragonolobus Linn., Blanco, ed. 1, 576; ed. 2, $402=$ Psophocarpus tetragonolobus (Linn.) DC.! T., Calamismis. I., Pal-lam.

Cytisus volubilis Blanco, ed. 1, 599; Cajanus volubilis Blanco, ed. 2, 417. Reduced by Villar to Atylosia mollis Benth., which is probably correct.

Cytisus cajan Linn., Blanco, ed. 1, 597 ; Cajanus bicolor DC., Blanco, ed. 2, $416=$ Cajanus indicus Spreng.! T., Caguois.

* Amerimnum mimosella Blanco, ed. 1, 563; ed. 2, 393 . Reduced by Villar to Dalbergia lanceolaria Linn., a species that certainly does not extend to the Philippines. Prain ${ }^{1}$ retains this as an imperfectly known species, Dalbergia mimosella (Blanco) Prain. Blanco's specimens were from Tala, Province of Rizal or Bulacan, flowering in June. T., Macapil.

Pterocarpus pallidus Blanco, ed. 1, 560; ed. 2, $391=$ Pterocarpus indicus Willd.! T., Asana. C., V., Naga. P., Daitanag.

Pterocarpus santalinus Blanco, ed. 1, 561; ed. 2, 392, non Linn. = Pterocarpus blancoi Merrill, Govt. Lab. Publ. 6:7. 1904. Pterocarpus santalinus Linn., does not extend to the Philippines. T., Narra, Naga. P., Apalit, Daitanag. V., Sanque?.

Galedupa maculata Blanco, ed. 1, 559; ed. 2, $390=$ Pongamia glabra Vent.! T., Balicbalic.

Galedupa frutescens Blanco, ed. 1, 559; ed. 2, 391. Reduced by Villar to Derris scandens Benth., which is probably correct. T., Malasaga.

Pterocarpus frutescens Blanco, ed. 1, 562; ed. 2, 392. Reduced by Villar to Derris uliginosa Benth., which is probably correct. T., Silasila.

* Pterocarpus diadelphus Blanco, ed. 1, 563; ed. 2, 393. Reduced by Villar to Derris thyrsiflora Benth., a species not known from the Philippines. Flowering in June. T., Silasila.

Sophora tomentosa Linn., Blanco, ed. 1, 328; ed. 2, 229.! T., B., Tambalisa, Cabaicabai, Yabag, Mantala, etc.

Sophora heptaphylla Blanco, ed. 1, 329; ed. 2; 229, non DC. Villar considers that Blanco describes DeCandolle's species, but Sophora heptaphylla certainly does not extend to the Philippines. It is apparently but a form of the preceding. T., Tambalisa, Cabaicabai.

${ }^{2}$ Ann. Bot. Gard., Calcutta, 10: 42.1904. 
Ormosia calavensis Blanco, ed. 2, 230.!

Guilandina bonducella Linn., Blanco, ed. 1, 343; ed. 2, $239=$ Caesalpinia bonducella (Linn.) Fleming.! T., Bayag cambing, Calambibit. V., Dalugdug.

Guilandina nuga Linn., Blanco, ed. 1, 344; ed. 2, $240=$ Caesalpinia nuga (Linn.) Ait.! T., Camit cabag.

Caesalpinia sappan Linn., Blanco, ed. 1, 335; ed. 2, 234.! T., Sapang, Sibucao.

Poinciana pulcherrima Linn., Blanco, ed. 1, 333; ed. 2, $232=$ Caesalpinia pulcherrima (Linn.) Swartz.! Sp.-Fil., Flores, Rosas, Caballero.

Caesalpinia torquata Blanco, ed. 1, 336; Mezoneurum procumbens Blanco, ed. 2, $235=$ Mezoneurum glabrum Desf.! T., Sagnit, Sapnit, Capitcabag. P., Sapnit. V., Tugabang, Ugabang.

Caesalpinia ignota Blanco, ed. 1, 336; ed. 2, $235=$ Mezoneurum pubescens Desf.!

Mimosa membranulacea Blanco, ed. 1, 739; Reichardia pentapetala Blanco, ed. 2, $233=$ Pterolobium indicum A. Rich.! I., Palo santo.

Cassia fistula Linn., Blanco, ed. 1, 339; ed. 2, 237.! Blanco includes in this species Cassia javanica Linn. T., P., Canafistula. V., Lombayong, Ibabao, Balayong.

Cassia occidentalis Linn., Blanco, ed. 1, 338; ed. 2, 236.! T., Tighiman.

Cassia tora Linn., Blanco, ed. 1, 337; ed. 2, 235.! T., Manimanihan, Mongomongohan, Catandang aso.

Cassia longisiliqua Blanco, ed. 1, 338, non Linn.; Cassia sulcata Blanco, ed. 2, 236, non DC. = Cassia hirsuta Linn.! T., Tighiman.

Cassia alata Linn., Blanco, ed. 1, 339; ed. 2, 237.! T., Sonting, Acapulco, Gamot sa buni, Catanda. V., Sunting, Casitas. P., Pacayomcom Castila.

Cassia mimosoides Linn., Blanco, ed. 1, 340; ed. 2, 237.!

Schotia speciosa Blanco, ed. 1, 356; ed. 2, 251, non Linn. Reduced by Villar to Cynometra ramiflora Linn., var. mimosoides Baker, which is probably an error. Doubtless the same as Cynometra inequalifolia A. Gray. T., Balitbitan.

Crudia spicata Blanco, ed. 2, 261, non Willd. = Crudia blancoi Rolfe.! T., Malatumbaga, Hintotoor.

Tamarindus indica Linn., Blanco, ed. 1, 29; ed. 2, $20 . !$ T., P., C., V., Sampaloc, Maca sampaloc. V., Sambac, Sumalagui, Camalagui, Sampalagui. I., Salomagui.

Eperua decandra Blanco, ed. 1, 368; ed. 2, $259=$ Intsia bijuga 0. Kuntze.! (Afzelia bijuga A. Gray.) T., Ipil, Taal.

Eperua falcata Blanco, ed. 1, 369, non Aubl.; Eperua rhomboidea Blanco, ed. 2, 260 = Pahudia rhomboidea (Blanco) Prain. (Afzelia rhomboidea Vidal.) T., Tindalo, Balayon. 
Bauhinia tomentosa Blanco, ed. 1, 330; ed. 2, 230, non Linn. Reduced by Villar to Bauhinia malabarica Roxb., which is probably correct. T., Alibanban. B., Livas, Alibanban, Balibanban, Marulinao, Diis, Ahihiro, Alambihor, Alibihil. P., Alibanban.

Bauhinia binata Blanco, ed. 1, 331; ed. 2, 231. Reduced by Villar to Bauhinia blancoi Baker, but if this is correct Blanco's name is the earlier. T., Alibanban.

Bauhinia scandens Blanco, ed. 1, 332; ed. 2, 232, non Linn. = Bauhinia cumingiana Benth.! Erroneously referred by Villar to Bauhinia vahlii W. et A., a species that does not extend to the Philippines. T., Banot.

* Bauhinia castrata Blanco, ed. 1, 331; Bauhinia purpurea Blanco, ed. 2, 231, non Linn. Considered by Villar to be identical with Bauhinia purpurea Linn., but this is certainly an error. Blanco's specimens. were from Pasig, flowering in October. Very near Bauhinia malabarica Roxb. T., Alibanban.

* Bauhinia grandiflora Blanco, ed. 1, 332; ed. 2, 231, non Juss. Reduced by Villar to Bauhinia variegata Linn., a species not known from the Philippines. Blanco's specimens were from Tayabas, a tree flowering in August. T., Bongalon.

Mimosa acle Blanco, ed. 1, 738; ed. 2, 509 = Pithecolobium acle (Blanco) Vidal.! Erroneously reduced by Villar to Xylia dolabriformis Benth. T., Acle.

Adenanthera gogo Blanco, ed. 1, 353; Entada pursaetha DC., Blanco, ed. 2, $247=$ Entada scandens (Linn.) Benth.! T., Gogo, Bayogo. B., P., Balogo, Gogong bacay.

Mimosa virgata Blanco, ed. 1, 737; Mimosa punctata Blanco, ed. 2, $508=$ Adenanthera pavonina Linn.! T., Quinasaicasai.

Mimosa peregrina Blanco, ed. 1, 737 ; ed. 2, 509, non Linn. = Parkia roxburghii G. Don.! T., Copang.

Mimosa asperata Blanco, ed. 1, 732; ed. 2, 505, non Willd. = Mimosa pudica Linn.! T., Macahiya.

* Mimosa quadrivalvis Blanco, ed. 1, 732; ed. 2, 506. Considered by Villar to be the same as Schranckia aculeata Willd., an American species, and one not definitely known from the Philippines. Blanco's specimens were from Bauang, Province of Batangas, flowering in September. T., Sapinit.

Mimosa farnesiana Linn., Blanco, ed. 1, 729; ed. 2, $504=$ Acacia far . nesiana (Linn.) Willd.! T., Aroma.

Mimosa tenuifolia Blanco, ed. 1, 739; ed. 2, 510, non Linn. = Acacia concinna DC.! T., Sibog.

Mimosa lebbek Blanco, ed. 1, 733; ed. 2, 506, non Linn. Reduced by Villar to Albizzia retusa Benth., which is probably correct. T., Langil.

Mimosa coriaria Blanco, ed. 1, 734; ed. 2, $506=$ Albizzia procera Benth.! T., Ayangao, Dariangao, Ananaplas. P., Anitap. I., Adaan. 
Mimosa carisquis Blanco, ed. 1, 731; ed. 2, 507. Reduced by Villar to Albizzia julibrissin Durazz., which is probably correct. T., Carisquis.

Mimosa unguis-cati Blanco, ed. 1, 7 3 i, non Linn.; Inga lanceolata Blanco, ed. 2, 370, non HBK. = Piricloiribium dulce Benth.! T., Camochiles, Camonsiles.

Mimosa scutifera Blanco, ed. 1, 735; ed. 2, 507. Reduced by Villar to Pithecolobium lobatum Benth., which is probably correct, although held by Bentham to be a distinct species, Pithecolobium scutiferum. T., Anagap.

\section{ROSACE $\mathrm{E}$.}

* Prunus armeniaca Blanco, ed. 2, 290, non Linn. Reduced by Villar to Prunus triflora Roxb., which is evidently an error. Blanco's specimens were from cultivated plants in Manila and in the Province of Cagayan. Sp.-Fil., Albaricoques.

Rubus moluccanus Linn., Blanco, ed. 1, 428; ed. 2, 298. Considered by Viliar to have been correctly identified by Blanco. T., Dagamit.

Rubus jamaicensis Blanco, ed. 1, 427, non Linn.; Rubus comintanus Blanco, ed. 2, 298. Reduced by Villar to Rubus rosæfolius Smith, which is probably correct. T., Sapinit, Sugmit.

\section{SAXAFRAGACEAL.}

* Malesherbia globosa Blanco, ed. 2, 454. Reduced by Villar to Hydrangea oblongifolia Blume, which is probably an error, possibly the same as Hydrangea lobbii Maxim. Blanco's specimens were from Bolhoon, Cebu. V., Mampol.

\section{CRASSULACE $\notin$.}

Cotyledon paniculata Blanco, ed. 1, 381, non Linn. f.; Bryophyllum germinans Blanco, ed. 2, $220=$ Bryophyllum calycinum Salisb.! T., Angelico, Catacataca.

Cotyledon serrata Blanco, ed. 1, 382, non Linn.; Bryophyllum serratum Blanco, ed. 2, $220=$ Kalanchce laciniata DC.!

Cotyledon lanceolata Blanco, ed. 1, 382, non Forsk; Bryophyllum triangulare Blanco, ed. 2, $221=$ Kalanchœ spathulata DC.!

\section{DROSERACEA.}

Drosera hexagynia Blanco, ed. 1, 226; ed. 2, $159=$ Drosera indica Linn.! T., Hintipalo.

\section{RHIZOPHORACE正.}

Rhizophora mangle Blanco, ed. 1, 397 ; ed. 2, 278, non Linn. = Rhizophora mucronata Lam.! T., Bacao, Bacauan.

Rhizophora longissima Blanco, ed. 1, 398; ed. 2, $278=$ Rhizophora conjugata Linn.! T., Tangal. V., Toñgog. 
Rhizophora candel Blanco, ed. 1, 396; ed. 2, 277, non Linn. = Ceriops candolleana Arn.! T., Ligasin, Tigasan. V., Pototan.

Rhizophora tinctoria Blanco, ed. 1, 394; Rhizophora gymnorrhiza Linn., Blanco, ed. 2, 276 = Bruguiera gymnorrhiza Lam.! T., Bacao, Bacauan. I., Oongon.

Rhizophora polyandra Blanco, ed. 1, 396; ed. 2, $277=$ Bruguiera eriopetala W. et A.! T., Bacao, Bacauan.

Rhizophora plicata Blanco, ed. 1, 398; ed. 2, 279. Reduced by Villar to Bruguiera malabarica Arn., a species not known from the Philippines, probably only a form of Bruguiera eriopetala W. et A. T., Bacao, Bacauan.

Biruguiera nemorosa Blanco, ed. 2, 275. Reduced by Villar to Carallia integerrima DC., which is probably correct.

\section{COMBRETACEAE.}

Terminalia latifolia Blanco, ed. 1, 376, non Swartz; Terminalia mauritiana Blanco, ed. 2, 264, non Lam. = Terminalia catappa Linn.! T., P., Talisai. P., Banilac, Nato, Hitam, Dalasa, Calisai. I., Lugo, Pandan.

Terminalia angustifolia Blanco, ed. 1, 377, non Jacq.; Terminalia edulis Blanco, ed. 2, 265. Erroneously reduced by Villar to Terminalia belerica Roxb., a species that does not extend to the Philippines. A very characteristic species, the second name being the correct one. T., Calumpit.

* Bucida comintana Blanco, ed. 1, 856; ed. 2, 265. Erroneously reduced by Villar to Terminalia chebula Retz., a species not known from the Philippines. Certainly not a species of Terminalia, but judging from Blanco's description, a species of Calycopteris. Blanco's specimens were from the town of San Jose, Province of Batangas, a tree flowering in May. T., Comintan, Dinglas.?

Gimbernatia calamansanay Blanco, ed. 2, $266=$ Terminalia calamansanay (Blanco) Rolfe.! Erroneously referred by Villar to Terminalia bialata Kurz, a species that does not extend to the Philippines. T., Calamansanai.

Petaloma coccinea Blanco, ed. 1, 345; ed. 2, $240=$ Lumitzera purpurea Presl.! (Lumnitzera coccinea W. et A.) T., Culasi.

Petaloma alba Blanco, ed. 1, 344; ed. 2, $240=$ Lumnitzera racemosa Willd.! T., Culasi.

Combretum distillatorium Blanco, ed. 1, 295; Combretum laxum Blanco, ed. 2, 206, non Roxb. = Combretum squamosum Roxb.! Erroneously reduced by Villar to Combretum ovalifolium Roxb., a species that certainly does not extend to the Philippines. I., Malacadog. T., Pamulaclaquin. 
* Gnidia oppositifolia Blanco, ed. 1, 299; ed. 2, 208. Reduced by Villar to Combretum wallichii DC., which is certainly an error, as that species does not extend to the Philippines. Possibly a species of Combretacea. Blanco's specimens were from Angat, Province of Bulacan, a small tree, flowering in December.

Quisqualis indica Linn., Blanco, ed. 1, 361; Quisqualis spinosa Blanco, ed. 2, 254. This species is reduced by Villar to Quisqualis malabarica Bedd., which is certainly an error. Blanco's species is certainly identical with Quisqualis indica Linn.! T., Niogniogan, Tagarao. V., Tangoton. P., Bebevabe. I., T'artarao.

Gronovia ternata Blanco, ed. 1, 187; ed. 2, $132=$ Illigera luzonensis (Presl.) Merrill, Govt. Lab. Publ. 17: 18. 1904. (Illigera meyeniana Kunth.)

Halesia ternata Blanco, ed. 1, 399; ed. 2, 279. Reduced by Villar to Illigera dubia Span., which is certainly an error. Certainly identical with the preceding.!

Gyrocarpus lobatus Blanco, ed. 2, 54=Gyrocarpus jacquini Roxb.! This species is described by Blanco, in the first edition under the native name only, Lapolapo.

\section{MYRTACEAE.}

* Metrosideros pictapetala Blanco, ed. 2, 295. Reduced by Villar to Metrosideros vera Rumph., which is evidently an error. Blanco's specimens were from Cebu, a tree flowering in September. V., Barit.

Psidium aromaticum Blanco, ed. 1, 417, non Aubl.; Psidium pyriferum Blanco, ed. 2, 292, non Linn. = Psidium guayava Linn. var.! T., Bayabas, Guyabas, Calimbahin.

Myrtus communis Blanco, ed. 1, 422; ed. 2, 295, non Linn. = Decaspermum blancoi Vidal.! Erroneously referred by Villar to Decaspermum rubrum Blume. T., Malatumbaga.

Eugenia jambos Blanco, ed. 1, 416; ed. 2, 290, non Linn. = Jambosa malaccensis (Linn.) DC.! T., Macupa, Yambo.

Eugenia malaccensis Blanco, ed. 1, 415; ed. 2, 290, non Linn. = Jambosa vulgaris DC.! T., Tampoi, Calobcob. V., Yampoi. P., Balobar.

* Eugenia montana Blanco, ed. 1, 418; ed. 2, 291, non DC. Reduced by Villar to Eugenia macrocarpa Roxb., a species not known from the Philippines. Certainly a species of Jambosa. Blanco's specimens were in part from Balanga, Province of Bataan, flowering in August. T., Copcop, Malaracopcop.

Myrtus mananquil Blanco, ed. 1, 421; Eugenia mananquil Blanco, ed. 2, 290. Reduced by Villar to Eugenia javanica Lam., probably the same as Jambosa aequa (Roxb.) DC. A tree flowering in April. T., Mananquil. 
* Eugenia bauanguica Blanco, ed. 1, 418; ed. 2, 290. Reduced by Villar to Eugenia laeta Ham., which is certainly an error. Related to if not identical with Jambosa malaccensis (Linn.) DC. Blanco's specimens were from Bauang, Province of Batangas, a shrub flowering in March.

* Myrtus tripinnata Blanco, ed. 1, 421; Myrtus subrubens Blanco, ed. 2, 294. Reduced by Villar to Eugenia cymosa Lam., a species not known from the Philippines. Certainly a species of Jambosa. A tree flowering in February. T., Malaruhat na pula.

* Calyptranthes makal Blanco, ed. 1, 419, non Rauesch.; Calyptranthes zuzygium Blanco, ed. 2, 293, non Swartz. Reduced by Villar to Eugenia operculata Roxb., which is certainly an error. A species of Syzygium.? A tree flowering in January. T., Malaruhat.

Calyptranthes jambolana Willd., Blanco, ed. 1, 418; Syzygium jambolana DC., Blanco, ed. 2, 293. The last name is correct. T., P., Lumboi, Duhat, Duat.

* Calyptranthes ramiflora Blanco, ed. 1, 420; Syzygium latifolium Blanco, ed. 2, 249, non DC. This species is reduced by Villar to Eugenia bracteata Roxb., a species that certainly does not extend to the Philippines. Blanco's specimens were from San Jose, Province of Batangas, a tree flowering in February. T., Dinglas.

* Eugenia glandulosa Blanco, ed. 1, 417; ed. 2, 291. A shrub flowering in July. Blanco's specimens were from Malinta, near Manila. Villar makes no attempt to reduce this species.

* Eugenia lobas Blanco, ed. 1, 857; Eugenia cauliflora Blanco, ed. 2, 291. A species quite unknown. Blanco's specimens were from trees cultivated in Manila, the fruit very acid. T., Lobas.

Barringtonia speciosa Forst., Blanco, ed. 1, 533; ed. 2, 373.! T., Botong, Botongbotong. V., Bitoon, Bitung, Botong.

Barringtonia stradivium Blanco, ed. 1, 533; Barringtonia racemosa Blume, Blanco, ed. 2, 373. The latter name is correct. T., Potat.

* Sulipa globosa Blanco, ed. 2, 348. Reduced by Villar to Planchonia littoralis Blume, which may be correct. Blanco's specimens were from Maragondon, Province of Cavite, the ripe fruits used for poisoning fish.

\section{MELASTOMATACEÆ.}

Osbeckia multiflora Blanco, ed. 1, 293, non Smith; Osbeckia sinensis Blanco, ed. 2, $205=$ Osbeckia chinensis Linn.!

* Melastoma aspera Blanco, ed. 1, 368; Melastoma obvoluta Blanco, ed. 2, 259. Reduced by Villar to Melastoma malabathricum Linn., but this is probably an error, as the latter species is not known from the Philippines. Blanco's specimens were from Angat. Probably the same as Melastoma obvolutum Jack. 
Melastoma tamonea Blanco, ed. 1, 367, non Sw.; Melastoma dodecandra Blanco, ed. 2, $258=$ Melastoma polyantha Blume.! Reduced by Villar to Melastoma imbricatum Wall., a species that does not extend to the Philippines. Blanco's specimens were from Panay, a shrub flowering in March.

Melastoma malabathrica Blanco, ed. 1, 367; ed. 2, 258, non Linn. $=$ Melastoma molle Wall.!. V., Buyong.

Memecylon parviflorum Blanco, ed. 1, 300; Memecylon tinctorium Blanco, ed. 2, $208=$ Memecylon edule Roxb.! Villar reduces Blanco's species to the variety ovata Clarke. T., Colis. I., Candon. V., Saguinsin.

Memecylon lanceolatum Blanco, ed. 1, 301; ed. 2, 209. Reduced by Villar to Memecylon cumingianum Presl., but it is probably only a form or variety of the preceding. T., Colis. I., Candong.

\section{LYTHRACEA.}

Ammania monoflora Blanco, ed. 1, 64; Ammania ramosior Blanco, ed. 2, 46, non ? Linn. This species is reduced by Villar to Ammania peploides Spreng. (Rotalia indica (Willd.) Koehne), which is apparently correct, although Koehne considers Blanco's species to be identical with Rotalia ramosior (Linn.) Koehne, an American species. Blanco states that the plant is very common, flowering in October, but so far as known no collector has secured specimens of Rotalia indica (Linn.) Koehne, in the Philippines.

Celosia nana Blanco, ed. 1, 192; Ammania debilis Blanco, ed. 2, 46, non Ait. = Ammania baccifera Linn.! T., Bias pogo.

Pemphis setosa Blanco, ed. 1, 410; ed. 2, $285=$ Pemphis acidula Forst.!

Lawsonia inermis Linn., Blanco, ed. 1, 294; ed. 2, 206.! Sp.-Fil., Cinamomo.

Quilamum luteum Blanco, ed. 1, 851; ed. 2, 136 = Crypteronia paniculata Blume.! Erroneously reduced by Villar to Crypteronia pubescens Blume, var. hookeri Clarke, a species that does not extend to the Philippines. T., Quilamo.

Lagerstroemia indica Linn., Blanco, ed. 1, 454; ed. 2, 316.! Sp.-Fil., Melindres.

Munchausia speciosa Linn., Blanco, ed. 1, 611; ed. 2, $427=$ Lagerstroemia speciosa (Linn.) Pers.! T., Banaba.

Sonneratia pagatpat Blanco, ed. 1, 424; ed. 2, 296.! This species was erroneously reduced by Villar to Sonneratia acida Linn. f. T., Pagatpat, Palatpat, Palapad.

Punica granatum Linn., Blanco, ed. 1, 422; ed. 2, 295.! Sp.-Fil., Granada. 


\section{ONAGRACEAE.}

Jussiæa inclinata Blanco, ed. 1, 366, non Linn.; Jussiæa fluviatilis Blanco, ed. 2, 257, non Blume $=$ Jussiaea repens Linn.! T., Cangcong dapo.

Jussiæa erecta Blanco, ed. 1, 365; ed. 2, 257, non Linn. = Jussiaca suffrutiosa Linn.! T., Malapaco, Balacbac.?

* Balingayum decumbens Blanco, ed. 1, 187; ed. 2, 132. This species and the genus is unknown. Villar retains it as a distinct genus of the Onagracece, but Bentham and Hooker, and Engler and Prantl refer it doubtfully to the genus Erythropalum in the Olacacea. Blanco's specimens were from Malinta, near Manila, a small prostrate plant, growing in wet places, rare and not well known to the natives. T., Balingayo.

\section{SAMYDACE $A$.}

* Laurus serrata Blanco, ed. 1, 319; ed. 2, 224. Reduced by Villar to Casearia glomerata Roxb., a species that certainly does not extend to the Philippines. Possibly a form of Casearia grewiafolia Vent. A shrub or small tree flowering in August. T., Inignin.

Samyda serrulata Blanco, ed. 1, 374, non Linn.; Samyda pubescens Blanco, ed. 2, 263, non Linn. = Casearia cinerea Turcz.! Erroneously reduced by Villar to Casearia tomentosa Roxb. T. Tulibas.

Anavinga fuliginosa Blanco, ed. 1, 372; Casearia fuliginosa Blanco, ed. 2, 262. Casearia leucolepis Turcz., is certainly a synonym of this species, and Blanco's name being the earlier should be retained. Erroneously reduced by Villar to Casearia grewicfolia Vent.

* Samyda trivalvis Blanco, ed. 1, 374; ed. 2, 263. Reduced by Villar to Casearia fragilis Vent., which is certainly an error, although probably correct as to the genus. Blanco's specimens were from Angat, Province of Bulacan.

* Gordonia polysperma Blanco, ed. 1, 549; ed. 2, 384. Reduced by Villar to Homalium foetidum Benth., a species not known from the Philippines. Undoubtedly a species of Homalium. Blanco gives no locality and no native name.

\section{PASSIFLORACEAE.}

Passiflora minima Blanco, ed. 1, 647, non Jacq.; Passiflora serrulata Jacq., Blanco, ed. 2, 452. The second name is undoubtedly correct. A cultivated plant flowering in August.

* Passiflora parviflora Blanco, ed. 1, 469, non Sw.; Modecca ? parviflora Blanco, ed. 2, 453. Reduced by Villar to Modecca cardiophylla Masters, a species that certainly does not extend to the Philippines. Blanco's specimens were from the mountains near San Mateo, Province of Rizal, fruit edible. T., Salapong. 
* Passiflora coccinea Blanco, ed. 1, (5.50, non Banks; Modecca ? coccinea 13lanco, ed. 2, 453. Redued by Villar to Modecea heterophylla Blume, a species as yet not known from the Philippines. Blaneo's speeimens were from the same locality as the preceding species. Fruit 2 inches loug, 2 inches in diameter, edible, flowering in June. T., Jelong ouac.

* Passiflora saponaria Blanco, el. 1, 650; Modecca ? saponaria Blanco, ed. 2, 453. Reduced by Villar to Modecca trilolata Roxb., a species that is unknown from the Philippines. Blanco's specinens were from Tagudin, Province of Ilocos Sur. 11., Libas.

* Passiflora zucca Blanco, ed. 1, 648; Modecca trilobata Blanco, ed. 2, 452, non Roxb. Reduced by Villar to Vodccea palmata Lam., a species that certainly does not extend to the Philippines, Blanco gives no locality for his specimens, which he states flower in June. Fruit red. T., Binoyoc boyoc.

Carica hermaphrodita Blanco, ed. 1, 803; ed. 2, 554. Carica papaya Linn., 33lanco, ed. 1, 803; ed. 2, 554. The latter name is correct. Carica hermaphrodita Blanco, is an abnormal form. Sp.-Fil., Papaya.

\section{CUCURRI'TACE.}

Trichosanthes amara Blanco, ed. 1, 774; ed. 2, 533, non Linn. Reduced by Villar to Trichosanthes palmata Roxb., but certainly identical with T. quinqangulata A. Gray! Not Luffa acutangula Roxb., as stated by Cogniaux. T., Salagsalag, Pacupis, Salimpocot, Hothot, Halahala, Buyocbuyoc. 13., P., T'abobog, Cucubitan, Pocotpocot, Curagda. Sp.-Fil., l'epinillo de San Gregorio.

Cucurbita lagenaria-oblonga Blanco, ed. 1, 772; ed. 2, 531 = Lagenaria vulgaris Seringe, var.! T., Tabayag.

Cucurbita lagenaria-villosa 13lanco, ed. 1, 772; ed. 2, $532=$ Lagenaria vulgaris Seringe, var.! T., Opo.

Mormordica operculata Blanco, ed. 1, 770; ed. 2, 530, non Linn. $=$ Luffa cylindrica Roem.! 'T., Salag salag.

Cucumis acutangulus Linn., Blanco, ed. 1, 776; ed. 2, 534=Luffa acutangula (Lim.) Roxb.! T., Patola.

Cucurbita pepo-aspera Blanco, ed. 1, 773; ed. 2, 532 = Benincasa cerifera Savi.! T., Condol.

Momordica cylindrica Blanco, ed. 1, 769; ed. 2, 530, non Linn. = Momordica charantia Linn.! Native names the same as for the next species.

Momordica balsamina Limn., Blanco, ed. 1, 768; ed. 2, 529.! T., Ampalaya, Apalaya, Amargoso. B., Palla, IIargoso. P., Apalia. 1., I'aria.

Momordica sphæroidea Blanco, ed. 1, 771 ; ed. 2, $531=$ Momordica cochinchinensis spreng.! 'T., Boyocboyoc.

$21896-4$ 
Cucumis melo Linn., Blanco, ed. 1, 775; ed. 2, 534. Reduced by Villar to Cucumis trigonus Roxb., but it is evident that Blanco correctly interpreted the species, and that the plant he describes is only a form of Cucumis melo Linn. T., Tabogo.

Cucurbita sulcata Blanco, ed. 1, 773; ed. 2, $532=$ Cucurbita maxima Duchesne.! T., Calabazang bilog.

Cucumis luzonicus Blanco, ed. 1, 861; ed. 2, 534. Reduced by Villar to Melothria indica Lour., which is probably correct. T., Melon daga.

\section{BEGONIACE $\nexists$.}

Begonia capensis Blanco, ed. 1, 724; ed. 2, 501, non Linn. Reduced by Villar to Begonia rhombicarpa A. DC., which is probably correct. T., Pingol bato.

\section{CACTACE $A \mathrm{E}$.}

Cactus pitajaya Blanco, ed. 2, 289, non Linn. Reduced by Villar to Cereus triangularis Haw., which is probably correct. Cultivated only.

Cactus opuntia Blanco, ed. 1, 414; ed. 2, 288, non Linn. Reduced by Villar to Opuntia cochinillifera Mill., which is probably correct. T., Sandoc sandoc, Dilang baca.

\section{FICOIDEA.}

Sesuvium portulacastrum Linn., Blanco, ed. 1, 426; ed. 2, 297.! T., Dampalit, Tarumpalit. V., Bilang bilang, Dampalit. P., Dampalit, Carampalit.

Portulaca toston Blanco, ed. 1, 408; Portulaca axilliflora Blanco, ed. 2, 285 = Trianthema monogyna Linn.! T., Toston.

Glinus lotoides Linn., Blanco, ed. 1, 413; ed. 2, 288.! T., Lobio.

Mollugo subserrata Blanco, ed. 1,51 ; ed. 2,34 . The same as the following species. T., Malagoso, Molugoso.

Mollugo stricta Linn., Blanco, ed. 1, 52; ed. 2, 35.! T., Malagoso, Molugoso.

\section{UMBELLIFERAE.}

Hydrocotyle asiatica Linn., Blanco, ed. 1, 212; ed. 2, 149.! T., Taquip suso, Taquip cohol.

Ammi glaucifolium Blanco, ed. 1, 213, non Linn.; Daucus anisodorus Blanco, ed. 2, 150. Reduced by Villar to Carum copticum Benth., which is probably correct. T., Lamudio, Damoro. B., Lamudio. P., Damoro.

Anethum foeniculum Linn., Blanco, ed. 1, 214; ed. 2, 150 = Foeniculum vulgare Mill.! T., Haras. 


\section{ARALIACEAE.}

* Aralia bipinnata Blanco, ed. 1, 222; ed. 2, 15i. Reduced by Villar to Aralia javanica Thunb., a species not known from the Philippines. A shrub, flowering in February. T., Potat.

Aralia tripinnata Blanco, ed. 1, 223; Panax fruticosa Blanco; ed. 2, $156=$ Panax fruticosum Linn.! T., P., Papua. B., Macan, Papua.

Aralia pendula Blanco, ed. 1, 223; ed. 2, $157=$ Polyscias nodosa Seem.! T., B., Bongliu, Bingliu, Biasbias, Malapapaya.

* Polyscias digitata Blanco, ed. 1, 224; Aralia ? octophylla Blanco, ed. 2, 158, non Lour. Reduced by Villar to Heptapleurum rigidum Seem., a species not known from the Philippines. Blanco's specimens were from Cebu, flowering in September. B., Tagima.

Polyscias odorata Blanco, ed. 1, 225; Paratropia crassa Blanco, ed. 2, $158=$ Heptapleurum venulosum Seem.! T., Limalima, Galamai amo. B., Cayangcan, Taguima, Calangcang, Carangcang, Limalima, Taguilima, Tuglima. P., Limalima.

Polyscias obtusa Blanco, ed. 1, 226; Paratropia obtusa Blanco, ed. 2, 226. Reduced by Villar to the preceding species, which is certainly correct.!

* Nauclea digitata Blanco, ed. 2, 102. This species is reduced by Villar to Heptapleurum cephalotes Clarke, a species not known from the Philippines. Very doubtful.! Blanco's specimens were from Angat, Province of Bulacan, native name not given.

* Polyscias disperma Blanco, ed. 1, 226. Reduced by Villar to Arthrophyllum diversifolium Blume, which is certainly an error. Blanco's specimens were from the seashore, Batangas. This species is excluded from the second edition.

* Polyozus bipinnatus Blanco, ed. 2, 43. Reduced by Villar to Arthrophyllum pinnatum Clarke, a species not known from the Philippines. Blanco's specimens were from Angat, Province of Bulacan, flowering in June.

\section{CORNACEAE.}

Alangium octopetalum Blanco, ed. 2, $310=$ Alangium lamarckii Thwaites.!

Guettarda jazminiflora Blanco, ed. 1, 722; Guettarda speciosa Blanco, ed. 2, 499, non Linn. Reduced by Villar to Marlea begonicefolia Roxb., which is probably correct. T., Calumpangin, Bagaolan.

\section{CAPRIFOLIACE.E.}

Sambucus javanica Blume, Blanco, ed. 2, 151.! 


\section{RUBIACEA.}

Nauclea lutea Blanco, ed. 1, 141; Nauclea glaberrima Blanco, ed. 2, 100, non Bartl. = sarcocephalus cordatus Miq.! Erroneously reduced by Villar to Sarcocephalus subditus Miq. 'T., Bangcal. V., Bancal, Cabag, Hanbabalos. P., Bancal. I., Bulala.

Nauclea glandulosa Jianco, edl. 1, 143; Nauclea glabra Blanco, ed. 2, $101=$ Nauclea blancoi Vidal.! Erroneonsly reduced by Villar to Anthocephalus cadamba Miq. T., Bagarilat.

Nauclea adina Blanco, ed. 2, 102, non Smith = Stephegyne diversifolia Hook. f.! This species is described in the first edition under the native name only, llambog. Erroneously reduced by Villar to Stephegyne parvifolia Korth., a species that does not extend to the Philippines. T., Ilambog.

* Mamboga capitata Blanco, ell. 1, 140; Nauclea luzoniensis Blanco, ed. 2, 102. Reduced by Villar to stephegyne speciosa Korth., which is probably an error. Probably a Tauclea or a Sarcocephalus. A very large tree. T., Mambog.

* Nauclea latifolia Blanco, ed. 1, 144; Nauclea obtusa Blanco, ed. 2, 101, non ? Blume. Villar considers that Blanco was correct in reducing his species to that of Blume, but Vauclea obtusa Blume, has not as yet been found in the Philippines. A tree flowering in August. T., Balod.

* Tapogomea rubra Blanco, ed. 1, 145; Cephaelis expaleacea Blanco, ed. 2, 103. Reduced by Villar to Uncaria acida Roxb., a species not known from the Philippines. Probably, however, a species of Uncaria. Blanco's specimens were from Cebu, flowering in April. I3., Iampol.

* Nauclea lanceolata Blanco, ell. 1, 144; Nauclea calycina 13lanco, ed. 2, 101, non ? Bartl. Reduced by Villar to Nauclea purpurea Roxb., a species not known from the Philippines. T., Bagarilao na itim.

Exostemma philippicum Blanco, ed. 2, 113, non R. et $\mathrm{s} .=$ Hymenodictyon excelsum Wall.! T., Huliganga.

Rondeletia asiatica Blanco, ed. 1, 146, non Linn.; Wendlandia exserta Blanco, ed. 2, 104, non DC'. = Wendlandia luzonensis 1$)($. Erroneously reduced by Villar to Wendlandia paniculata $\mathrm{D})($.

Dentella repens Forst., 13lanco, ed. 1, 146; ed. 2, 103.! T., Dilang butiqui.

Oldenlandia capensis Blaneo, rd. 1, 62 ; ed. 2, 4.5, non Thunb. = Oldenlandia diffusa Roxb.!

Oldenlandia paniculata Linn., Blaneo, el. 1, 61; od. 2, 44.!

Oldenlandia affinis Blanco, exl. 2, 44, non R. et $S$. Reduced by Villar to Oldenlandia nudicaulis Roth., which is certainly an error, although the latter species has been found in the Philippines. Probably a form of Oldenlandia corymbosa Linn. 
Ophiorrhiza oblongifolia 1$)($., Blaneo, ed. 2, 64.!

Mussaenda frondosa Blanco, ed. 1, 167; ed. 2, 118, non Linn. = Mussuenda grandiflora (Meyen.) Rolfe.! T., Tingatinga. 1., Balailamoc.

* Stigmanthus cymosus Blanco, ed. 2, 117. Reduced by Villar to Webera odorata Roxb., which is certainly an error, as that species does not extend to the Philippines. If a species of Webera, probably the same as W. luzonensis Vidal. Blaneo's specimens were from Calauan, Province of Laguna, native name not given.

* Randia aculeata Blanco, ed. 1; 141; ed. 2, 99. Reduced by Villar to Gardenia dumetorum Lann., which is probably an error, as the latter species is unknown from the Philippines. Blanco's specinems were from Bauang, l'rovince of Batangas, a shrub growing on the seashore, flowering in May. 'T., sinampaga.

* Remijia odorata Blanco, ed. 2, 115. Reduced by Villar to Randia densiflora Benth., which may be correct, although the latter species is not known from the Philippines at the present time. Blanco's specimens were from Bauang, Province of Batangas, native name not given.

* Serissa myrtifolia Blanco, ed. 1, 164; Remijia angatensis Blanco, ed. 2, 115. Transferred to Randia by Villar, as a distinct species Randia angatensis (Blanco) F.-Vill. A slurub, known only from Blanço's description, flowering in August, 13lanco's specimens being from Angat, Province of Bulacan. 'T., Caragli.

Serissa pinnata Blanco, ed. 1, 163; Remijia obscura Blanco, ed. 2, 116 = Gardenia PINATA (Blanco) (Gardenia obscura Vidal; Randia obscura F.-Vill.). T., Caragli. P., Pagbut.

Sulipa pseudopsidium Blanco, ed. 1, 497; ed. 2, $347=$ Gardenia pseudopsidium (Blanco) F.-Vill.! T., Calapi, Sulipa, Malabayabas.

Ixora manila Blanco, ed. 1, 60; ed. 2, $42=$ scyphiphora hydrophyllacea Gaertn.! T., Nilad, Nilar.

* Ixora glandulosa Blanco, ed. 1, 61; ed. 2, 42. Reduced by Villar to Canthium confertum Korth, which is probably an error, as that species is unknown from the Philippines. T., Malapatopat.

Ronabea bipinnata Blanco, ed. 1, 162; Ronabea arborea Blanco, ed. 2, 114 = Canthium BipinNatum (Blanco) (Canthium arboreum Vidal.). This species was erroneously referred to Canthium mite. Bartl., by Villar. T., Tadiang anunang. I., Pamalatanguen.

Canthium pauciflorum Blanco, ed. 1, 165; Canthium horridum Blume, Blanco, ed. 2, 116. The latter name is correct. T., Suliac daga.

Canthium monoflorum Blanco, ed. 1, 166; Canthium pedunculare Cav., Blanco, ed. 2, 116. The latter name is correct.

* Vangueria stellata Blanco, ed. 1, 167; ed. 2, 117. Reduced by Villar to Tangueria spinosa Roxb., which is probably an error, as Blanco's species does not appear to belong to this genus. A tree flowering in August. 'T., Malaas-is, Madondon. 
Ixora coccinea Linn., Blanco, ed. 1, 59; ed. 2, 41.! Villar reduces this species to Ixora stricta Roxb., but Blanco describes the common cultivated form, which is apparently not a native of the Philippines. T., Santan, Santa Ana.

* Ixora arborea Blanco, ed. 1, 61; ed. 2, 42. Reduced by Villar to Ixora stricta Roxb., which is certainly an error. A tree flowering in August. T., As-as.

* Taligalea umbellata Blanco, ed. 2, 337. Reduced by Villar to Ixora macrohylla Bartl., which must be considered doubtful. Blanco's specimens were from Cebu, flowering in March. V., Bagobago.

* Pavetta membranacea Blanco, ed. 1, 59; Pavetta sambucina Blanco, ed. 2, 41, non DC. Reduced by Villar to Pavetta angustifolia R. et S., which is probably an error. Blanco's species may be a form of Pavetta indica Linn., or a distinct species. His specimens were from Angat, flowering in September.

Coffea arabica Linn., Blanco, ed. 1, 156; ed. 2, 110.! Sp.-Fil., Café.

Morinda litoralis Blanco, ed. 2, $109=$ Morinda citrifolia Linn.!

Morinda citrifolia Blanco, ed. 1, 149; Morinda ligulata Blanco, ed. 2, $105=$ Morinda bracteata Roxb.! T., V., Bancudo, Pancudo, Bangcoro, Nino, Culit, Tumbong aso, Lino, Mambog, Tacpus. P., Taliantar. I., Apatot.

Morinda royoc Blanco, ed. 1, 148; ed. 2, 105, non Linn. = Morinda tinctoria Roxb.! T., Tumbong asong hapay.

Morinda umbellata Blanco, ed. 2, 110. Reduced by Villar to Morinda microcephala Bartl., but it is evident that Blanco correctly interpreted the Linnean species.

* Coffea volubilis Blanco, ed. 1, 157; ed. 2, 11l. Reduced by Villar to Morinda tinctoria Roxb., which may be correct. A scandent shrub, flowering in August. T., Halon.

Pæderia tacpo Blanco, ed. 1, 160; ed. 2, 113=Psychotria tacpo (Blanco) Rolfe.! Erroneously reduced by Villar to Psychotria malayana Jack. T., Tacpo.

Pæderia fœetida Blanco, ed. 1, 159; ed. 2, 112, non Linn.=Paederia tomentosa Blume.! T., Cantotai. B., Lilitan. P., Cantotai, Dicuta maboloc, Mabatang dicut.

Spermacoce mutilata Blanco, ed. 2, 43 = Spermacoce hispida Linn.!

Spermacoce muriculata Blanco, ed. 2, 44. This species is reduced by Villar to Spermacoce scaberrima Blume, probably a form of the preceding species. Blanco's specimens were from Guadalupe, near Manila.

\section{COMPOSITA.}

Serratula multiflora Blanco, ed. 1, 617; ed. 2, 431, non Linn. = Vernonia chinensis Less.! T., Bayaquiboc.

Elephantopus scaber Linn., Blanco, ed. 1, 634; ed. 2, 441.! 
Elephantopus serratus Blanco, ed. 1, 635; ed. 2, 442. Reduced by Villar to Elephantopus mollis HBK., which is probably correct.

Ageratum quadriflorum Blanco, ed. 1, 624; Elephantopus ? dubius Blanco, ed. 2, $442=$ Elephantopus spicatus 13. Juss.! 'T., Dilang usa, Tabatabacohan, Sigang dagat. P., Sumag. B., Habul, Ardotag. I., Cabcabron.

Eupatorium ayapana Vent., Blanco., ed. 1, 619; ed. 2, 432.! Sp.-Fil., Ayapana.

Knautia sagittata Blanco, ed. 1, 54; ed. 2, 36= Milania scandens Willd.!

Perdicum tomentosum Blanco, ed. 1, 630 ; ed. 2, $439=$ Grangea maderas patana Poir.!

* Baccharia ivæfolia Blanco, ed. 1, 627; ed. 2, 437, non Linn. Reduced by Villar to Conyza viscidula Wall., which may be correct. B., Tagabili.

* Conyza gouani Blanco, ed. 1, 629, non Wild.; Conyza erosa Blanco, ed. 2, 439. Reduced by Villar to Blumea manillensis 1C., which may be correct.

Conyza balsamifera Linn., Blanco, ed. 1, 628; ed. 2, $438=$ Blumea balsamifera DC.! T., Sambon. V., Lacdanbulan, Hamlibon, Lalacdan, Lacad bulan, Guintenguinten, Gabuen, Ayoban, Alibun. P., Sambon. I., Sobsob.

Baccharis indica Linn., Blanco, ed. 1, 627; ed. 2, $438=$ Pluchea indica (Linn.) Less.!

Sphæranthus alatus Blanco, ed. 1, 635.; Sphæranthus indicus Blanco, ed. 2, 442, non Linn. = Spharanthus africanus L.! T., Sambong gala.

Sphæranthus elongatus Blanco, ed. 1, 636; ed. 2, $443=$ Pterocaulon cylindrostachyum Clarke.! T., Sambong gala.

Xeranthemum stæhelina Blanco, ed. 1, 629; non Don.; Gnaphalium dichotomum Blanco, ed. 2, 439, non Wild = Gnaphalium luteo-album Linn.! Reduced by Villar to Gnaphalium indicum Linn. Blanco's specimens were from Agoo, Province of Union. I., Badoc.

* Conyza dentata Blanco, ed. 1, 629, non Linn.; Conyza cappa Blanco, ed. 2, 438, non Ham. Reduced by Villar to Inula cappa DC., which is certainly an error. Possibly a species of Blumea.

Anthemis cotula Blanco, ed. 1, 633, non Linn.; Artemesia viridis Blanco, ed. 2, 436, non Linn.=Eclipta alba Hassk.! T., Higuis manoc. I., Tintatinta.

Spilanthes acmella Blanco, ed. 1, 420; ed. 2, 433, non DC. $=$ Wedelia biflora DC.! Villar considers that Blanco correctly interpreted DeC'andolle's species, but his description certainly applies to Wedelia biflora DC. T., Hagonoi. V., Agonoi. P., Palunai.

Spilanthes lobata Blanco, ed. 1, 622; ed. 2, $434=$ Spilanthes acmella Linn.! T., Hagonoi.

Spilanthes peregrina Blanco, ed. 1, 622; ed. 2, 434. Certainly only a form of Wedelia biflora DC.! T., Hagonoi. 
Coreopsis gracilis Blanco, ed. 2, 591 = Cosmos caudatus HBK.!

Bidens bipinnata l3lanco, ed. 1, 62:3; edl. 2, $435=$ Bidens pilosa Linn.!

Tagetes patula Linn., Blanco, ed. 1, 632; ed. 2, 440.! Cultivated only. Sp.-Fil., Amarillo.

Matricaria chamomilla Blanco, ed. 1, 631; ed. 2, 440, non Linn. = Chrysunthemum indicum Limn.! Sp.-Fil., Manzanilla.

Cotula quinqueloba Blanco, ed. 1, 626 ; ed. $2,436=$ Centripeda orbicularis Lour.! T., V., Harangan. V., Pissic.

Artemesia vulgaris Linn., Blanco, el. 1, 625; ed. 2, 435. The identification of this species seems to be correct. T., Ca Maria, Santa Maria, Tinisas.

* Cacalia sarrasenica Blanco, ed. 1, 618; non Linn.; Senecio cacaliaster Blanco, ed. 2, 441, non Lam. Reduced by Villar to Gynura angulosa DC., a species that is not known from the Philippines. Flowering in August. T., Sampaga del monte.

Cacalia sonchifolia Linn., Blanco, ed. 1, 618; Emilia sonchifolia (Linn.) DC. Blanco, ed. 2, 432. The second name is correct. T., Tagolinao. P., Tagulinao. B., Libun.

Carthamus tinctorius. Linn., Blanco, ed. 1, 616; ed. 2, 431.! T., Biri, Casubha, Lago. V., Casabha. P., Casubha, Cachumba.

\section{GOODENIACEA.}

Scaevola lobelia Blanco, ed. 1, 147; ed. 2, 104, non Murr. = Scaevola koenigii Vahl.! T., V., Boto, Bosboron, ILosboron, Bocaboc, Panabolong, Pangangtolong. Z., Linog.

\section{CAMPANULACEAS.}

Pongatium spongiosum Blanco, ed. 1, 86; Sphenoclea zeylanica Gaertn., Blanco, ed. 2, 62. The latter name is correct.! 'T., Silisilihan.

Reichelia palustris Blanco, ed. 1, 220; ed. 2, 155. The same as the preceding.!

\section{ERICACEA.}

Clethra alnifolia Blanco, ed. 2, 259, non Linn. = Clethra lancifolia Turcz.! T., Malaclac.

\section{PLUNBAGINACEA.}

Plumbago viscosa Blanco, el. 1, 78; ed. 2, 58 = I'lumbago $\approx$ eylanica Linn.! T., Sangdigquit. I., Bangbang, Talancao.

\section{MYRSINACEAS.}

Bassovia sylvatica Blanco, ed. 2, 9.). Reduced by Villar to Macsa indica A. DC:, a species that does not extend to the Philippines. Probably the same as the species deseribed by Mez as Maesa laxa. Mlanco's specimens were from Angat, a small shrub, flowering in February. T., Solinas. 
Maesa membranacea 13lanco, el. 2, 590, non A. DC. = Macsa cumingiana Mez.!

Bladhia japonica Blanco, ed. 1, 126: ed. 2, 90, non Thumb. Reduced by Villar to Ardisia pyramidalis Pers. = Ardisia sorrata (c'av.) Pers. Questionably referred here by Mez, but Villar is probably correct. Flowering in August. T., Tucpong dalaga.

Willughbeia drupacea Blanco, ed. 1, 132; ed. 2, 94. This species is reduced by Villar to Ardisia obotata Blume, which is a synonym of Ardisia humilis Vahl., certainly correctly referred.!

Aegiceras corniculatum (Linn.) Blanco, ed. 1, 79; ed. 2, 59. This name is correct, Aegiceras majus Gaertn., is a synonym. T., Tingang baguis, Pipisic.

\section{SAPOTACEA.}

Achras lucuma Blanco, ed. 1, 23i ; ed. 2, 166, non Ruiz et Pav. = Lucuma mammosa Gaertn.! T., Mamei.

Sideroxylon-duclitan Blanco, ed. 1, 129; ed. 2, 92 . A distinct species, flowering in September. 'T., Duclitan, Dulitan.

* Sideroxylon balitbitan 13lanco, el. 1, 130; ed. 2, 92. Probably a distinct species, but certainly closely related to the preceding. T., Balitbitan.

Achras sapota Linn., Blanco, ed. 1, 236; ed. 2, 165.! Sp.-Fil., Chicos.

Palaquium lanceolatum Blanco, ed. 1, 403; ed. 2, 282.! A distinct species. 'T., Bagalangit.

Palaquium latifolium Blanco, ed. 1, 404; ed. 2, 282.! A distinct species. T., P'alac palac.

Palaquium oleiferum Blanco, ed. 1, 405; ed. 2, 283.! A species closely related to the preceding. I., Daracan.

Azaola betis Blanco, ed. 1, 402; ed. 2, $281=$ Illipe betis (Blanco) Merrill (Payena betis F.-Vill.). 'T., P., Betis.

\section{EBENACEAE.}

Diospyros pilosanthera Blanco, ed. 1, 304; ed. 2, 211. A good species. T., Bolong eta. B., Dalondong, Amaga.

Diospyros multiflora Blanco, ed. 1, 303, non Wall.; Diospyros lotus Blanco, ed. 2, 210, non Linn. = Diospyros canomoi A. DC.! A distinct species. T., Canomoi, Canomai.

* Diospyros biflora Blanco, ed. 1, 303; ed. 2, 210. Possibly a good species, at present known only from Blanco's description. A tree flowering in June. 'T., Talang.

* Diospyros kaki Blanco, ed. 2, 211, non ? L. f. Possibly this may be the same as the species described under this name by Linnaeus, f., and Villar so considers it. Blanco's specimens were from Mahaihai, Provine of Laguna, known there as Pagatpat. Blaneo had only fruits. Diospyios liaki of the seond edition is entirely different from $D$. kaki of the first edition. 
Sapota nigra Blanco, el. 1, 409; Diospyros nigra Blanco, ed. 2, $211=$ Diospyros ebenaster Retz.! Sp.-Fil., Zapote negro.

Diospyros kaki Blanco, ed. 1, 302, non Linn.; Diospyros embryopteris Blanco, ed. 2, 209, non Pers. = Diospyros philippensis (Desr.) Gurke! (D. discolor Willd.). T., Talang, Mabolo. V., Amaga. P., Talang.

\section{STYRACEAE.}

Guettarda polyandra Blanco, ed. 2, 500 = Symplocos polyandra (Blanco?) A. Brand. Villar erroneously refers this species to Symplocos racemosa Roxb.

\section{OLEACEA.}

Nyctantes sambac Linn., Blanco, ed. 1, 9; ed. 2, $6=$ Jasminum sambac (Linn.) Ait. T., Sampaga. V., Capopot visaya, Manul. P., Campopot, Sampagang pougso, Culatai.

* Mogorium aculeatum Blanco, ed. 1, 9; ed. 2, 7. Reduced by Villar to Jasminum marianum DC., but this species is not known from the Philippines. Possibly a distinct species of Jasminum. Flowering in May.

\section{SALVADORACEAE.}

Azima nova Blanco, ed. 1, 68; ed. 2, 49. Considered by Vidal as a distinct species, although reduced by Villar to Azima tetracantha Lam. It may be the same as Azima sarmentosa Blume.

\section{APOCYNACEAE.}

Allamanda cathartica Linn., Blanco, ed. 2, 64.!

Brabejum ? lucidum Blanco, ed. 2, $40=$ GrNopogon monilifera (Vid.). (Alyxia monilifera Vid.). Erroneously reduced by Villar to Alyxia stellatum R. et S. Blanco's specimens, were from the pueblo of Bolohan, Cebu. V., Layo.

* Brabejum ? concatenatum Blanco, ed. 2, 40. Reduced by Villar to Alyxia laurina Gaud., a species not known from the Philippines. Blanco's specimens were from Cebu. Probably a distinct species of Gynopogon.

* Brabejum ? pinnatum Blanco, ed. 2, 40. Reduced by Villar to Alyxia odorata Wall., which is probably an error. Blanco's specimens were from Cebu. Probably a distinct species of Gynopogon. V., Layo.

Cerbera thevetia Linn., Blanco, ed. 1, 125; ed. 2, $89=$ Thevetia neriifolia Juss.! Introduced from America. Sp.-Fil., Campanelo.

Cerbera manghas Blume, Blanco, ed. 1, 125; ed. 2, $89=$ Cerbera odollam . Gaertn.! T., Toctoc calo.

* Elcana seminuda Blanco, ed. 2, 584. Reduced by Villar to Cerbera lactaria Ham., a species that does not extend to the Philippines. Possibly a species of Cerbera. Blanco's specimens were from Angat, Province of Bulacan.

Vinca rosea Linn., Blanco, ed. 1, 116; ed. 2, 84.! T., Cantotan. 
Plumeria alba Blanco, ed. 1, 111; ed. 2, 80, non limn. = Plumeria anutifolia Poir. 'T., Curachucha, Calachuchi, C'alasusi.

Echites scholaris Linn., Blanco, ed. 1, 106; ed. $2,7 \tau=$ Istonia scholaris (Linn.) R. Br.! T., Dita. I., Dalloparen.

Echites trifida Blanco, ed. 1, 109; ed. 2, 79 , non Jacq. Reduced by Villar to Alstonia spectabilis Miq., but it is certainly Alstonia macrophylla Wall.! T., Cayaocayao, Batino.

Alstonia batino Blanco, ed. 2, $589=$ Alstonia macrophylla Wall.! T., Batino.

Tabernaemontana globosa Blanco, el. 1, 116; el. 2, 83 = Voacanga cumingiana Rolfe (V. foetida F.-Vill., non Blume). A small tree flowering in August. T., Bayag usa.

Tabernaemontana laurifolia Blanco, ed. 1, 114; ed. 2, 82, non Linn. = T'abernaemontana pandacaqui Poir.! T., Campopot, Pandacaqui. B., Alibutbut, Toar, Pandaya. P., Pandacaqui. I., Curribuetbuet.

* Tabernaemontana polygama Blanco, ed. 2, 82. Considered by Villar to be a distinct species. Blanco's specimens were from Parañaque and Mandoloyon, near Manila, flowering in May.

Echites repens Blanco, ed. 1, 109, non Jacq.; Echites procumbens Blanco, ed. 2, $78=$ Holarrhena procumbers (Blanco). Erroneously reduced by Villar to Holarrhena macrocarpa (Hassk.) F.-Vill. See Nos. 1844 and 3299 Merrill, and No. 298 Whitford. T., Malayantoc, Hinguiu.

Echites spiralis Blanco, ed. 1, 110 ; ed. 2, $79=$ Parsonsia rheedii F. Vill.! This species is figured in the third edition of the Flora de Filipinas, $t$. 310, also by Vidal, Sinopsis, Atlas, t. 66. $f$. E., while a full description is given by Vidal, Revision, 184 .

Anasser laniti Blanco, ed. 1, 112; ed. 2, $81=$ Wrightia LANiti (Blanco) (Wrightia ovata A. DC.!). Blanco's name is the earliest for this species and should be retained. T., Laniti.

Nerium oleander Blanco, ed. 1, 104; ed. 2, 75, non Linn. = Nerium odorum Soland.! Sp.-Fil., Adelfa. T., Baladre.

Echites caudata Blanco, ed. 1, 106; ed. 2, 77, non Linn. = Ichnocarpus navesii Rolfe!! Erroneously reduced by Villar to Ichnocarpus frutescens R. Br. T., Hinguio.

Tabernaemontana elliptica Blanco, ed. 1,116 ; ed. 2, 83, non Thunb. $=$ Choneomorpha macrophylla Wall.! Blanco's specimens were from Tala, Province of Rizal or Bulacan, a scandent shrub, flowering in - July.

\section{ASCLEPIADACEAE.}

* Tabernaemontana cirrhosa Blanco, ed. 1, 115; ed. 2, 83. Reduced by Villar to Finlaysonia obovata Wall., which is certainly an error. Blanco's specimens were from Bauang, Province of Batangas, a scandent shrub growing along the seashore, in situations subject to inundation. 
* Apocynum mucronatum 3lanco, c(l. 1, 8.52; ed. 2, 143. Reduced ly Villar to Toxocarpos gracilis Deenc., which is very doubtful. A vine flowering in May.

Asclepias gigantea Willd., Blanco, ed. 1, 207; ed. 2, $140=$ Calotropis gigantea R. 13r.! T., C'apalcapal.

Asclepias syriaca Blanco, el. 1, 204; ed. 2, 144, non Linn. = Asclepias curassavica Linn.! T., Bulac castila.

* Cynanchum viminale Blanco, ed. 1, 203; ed. 2, 143, non ? Linn. Villar considers that Blanco describes the Limnean species, but this is probably an error, unless Blanco described an introduced plant. Blanco's species may be referable to Sarcostemma brevistigma W. et A. A vine, flowering in February, known in Manila as Mil leguas.

* Asclepias peregrina Blanco, ed. 1, 207; ed. 2, 146. Reduced by Villar to Sarcolobus carinatus Wall., which is certainly an error. Blanco's specimens were from Bauang, Province of Batangas, growing in situations subject to inundation, along the seashore.

Asclepias dæmia Blanco, ed. 1, 208; ed. 2, 146, non Forsk. Reduced by Villar to Gymnema tingens $\mathrm{Wr}$. et A., which is probably correct.

Cynanchium tenellum Blanco, ed. 1, 204; ed. 2, 143, non Linn. Reduced by Villar to Tylophora perrottetiana Decne., which is probably correct.

Marsdenia akkar Blanco, ed. 1, 118; ed. 2, 85. Reduced by Villar to Marsdenia tinctoria R. Br., which is probably correct. B., Payanguit, Aringit.

* Marsdenia tagudina Blanco, ed. 1, 121; ed. 2, 86. Considered by Villar to be a distinct species. Blanco's specimens were from the pueblo of Taguding, Province of Ilocos Sur. I., Tayomtayom.

* Pergularia glandulosa Blanco, ed. 1, 202; ed. 2, 141. Reduced by Villar to Pergularia minor Andr., which is probably an error. Blanco's specimens were from Bauang, Province of Batangas, flowering in July.

* Pergularia procumbens Blanco, el. 1, 204; Pergularia glabra Blanco, ed. 2, 14l. Considered by Villar to be a distinct species, possibly however a synonym of I'ergularia odoratissima Sm. Blanco's speci- mens were from Manila. T., Mil leguas.

Stapelia quadrangula Blanco, ed. 1, 202; ed. 2, 142, non Forsk. = Heterostemma cuspidatum Decne.! T., Biniguasan.

Cynanchium hirtum Blanco, ed. 1, 203; ed. 2, 143, non Linn. Reduced by Villar to Dregea viridifora (J)C.) F.-Vill., which is probably correct. Blanco's specimens were from Malinta, near Manila.

* Stapelia meliflua I3lanco, ed. 1, 202; ed. 2, 142. Reduced by Villar to Hoya diversifolia Blume, a species not known from the Philippines. Certainly a species of Hoya, hut not that species. A vine, flowering in June. 'T., Balicbalic.

* Hoya carnosa J3lanco, non ? R. Br., ed. 2, 142. Jilentification possibly correct. Blaneo's specimens were from cultivated plants. 
- Marsdenia parasita Blaneo, ed. 1, 120: ed. 2. 86. Reduced by Villar to Hoya parasitica Wall., which is certainly an crror. Certainly, however, a species of Hoya.! Blaneos specimens were epiphytes growing on Erythrina and on I/angifera, flowering in May, frniting in .Jmme.

Asclepias carnosa Blauco, ed. 1, 208; ed. 2, $147=$ Hoye multiflora Blume.!

\section{LOGANIACEA.}

Buddleia virgata Blanco, ed. 1, 57; ed. 2, 38, non Limn. Rednced by Villar to Buddleia necmda Hamilt., but certainly is Buddleia asiatica Lour.! T., Talicnono. I., Tugnang. B., Lagundi salasa.

Fagraea scholaris Blanco, ed. 2, 93. Reduced by Villar to Fagraca cordifolia Blume, a species not known from the Philippines. Probably the same as Fagraca morindacfolia Blume. T., Cabal.

* Tayotum nigrescens Blanco, ed. 1, 105; ed. 2, 76. Redneed by Villar to Norrisia malaccensis Gardn., which is undoubtedly an error. Blanco's specimens were from Angat, Province of Bulacan, a shrub flowering in Jume. T., Saguing saguing, Tayoto.

Ignatia amara Linn. f., Blanco, ed. 1, 82; Strychnos philippensis Blanco, ed. $2,61=$ strychnos ignatii Berg.! Retained under the second name by Villar. For full synonomy see Hooker's Icones, Vol. 25: pl. ?2.12, 2213. T., Pepita, Fruta. P., Pepita sa catbalogan. V., Pangaguason, Aguason, Canlara, Mana-naog, Dancagi, Catalonga, Igasud.

\section{GENTIANACEAE.}

Exacum albens Blanco, ed. 1, 58; ed. 2, 39, non Linn. f. Reduced by Villar to Exucum chironioides Griseb., probably, however, the same as Exacum tetragonum Roxb.

Cobamba dichotoma Blanco, ed. 1, 510; ed. 2, 355. Reduced by Villar to Canscoria diffusa R. Br., which is certainly correct.! T., Codamba.

* Codamba blancoi Azaola, in Blanco, ed. 2, 591. Reduced by Villar to Canscoria decussata R. et $\mathrm{S}$., which is certainly an error. The material on which this species was based was from Gumai, Province of Pampanga. A form of the preeeding species.?

Menyanthes indica Bory, Blanco, ed. 1, 87; ed. 2, 63=Limnanthemum cristatum Griseb.! T., Lauas. I., Locloquisin.

\section{HYDROPHYLLACEA.}

Hydrolea arayatensis Blanco, ed. 1, 211; Hydrolea zeylanica Vahl., Blanco, ed. 2, 148. The second name is correct.

\section{BORAGINACEA.}

Cordia banalo. 13linco, el. 1, 124; Cordia ? ignota Blanco, ed. 2, 88= Cordie subcordata Lam.! T., Banalo. 
Cordia sebestena Blanco, ed. 1, 121; ed. 2, 87, non Linn. = Cordia dichotoma Blanco, ed. 1, 123; ed. 2, 88, non Forst. = Cordia blanco $i$ Vidal.! Erroneously referred to Cordia myxa by Villar. T., Anonang. V. Anonang, Bilibi.

Ehretia beurreria Blanco, ed. 1, 127; ed. 2, 91, non Linn. = Ehretia philippinensis A. DC.!

Ehretia virgata Blanco, ed. 1, 12 7 ; ed. 2, 165, non Swartz. = Ehretia onava A. DC.! T., Onava.

Menais mollis Blanco, ed. 1, 139; ed. 2, $99=$ Ehretia navesii Vidal (Ehretia mollis Merrill). This species was erroneously referred by Villar to the preceding species. T., Taglocot.

Carmonia heterophylla Cav., Blanco, ed. 1, 209; ed. 2, $147=$ Ehretia buxifolia Roxb.! T., B., Alanguit, Alangitngit.

Coldenia procumbens Linn., Blanco ed. 1, 74; ed. 2, 56.! T., Tapiasin, I., Tabtabocol.

Tournefourtia arborea Blanco, ed. 1, 129; ed. 2, 91= Tournefourtia argentea Linn. f.!

Tournefourtia hirsutissima Blanco, ed. 1, 128; ed. 2, 91, non Linn $=$ Tournefourtia sarmentosa Linn.! V., Patai ood. I., Sallacapo.

Heliotropum parviflorum Blanco, ed. 1, 80; ed. 2, 59= Heliotropum indicum Linn.! T., Hinlaylayon, Cotingcotingan.

Borago indica Linn., Blanco, ed. 2, 60. Reduced by Villar to Trichodesma indicum R. Br., which is probably correct. Blanco's specimens were from Paranaque, near Manila.

Borago indica Blanco, ed, 1, 81, non Linn.; Borago africana? Blanco, ed. 2, 60 = Trichodesma zeylanicum R. Br.! T., Sigang dagat, Dilan usa.

\section{CONVOLNULACEA.}

Convolvulus muricatus Blanco; ed. 1, 92; ed. 2, 68, non Linn. = Ipomœa bona-nox Linn.! T., Camo camotihan.

Ipomoea quamoclit Linn., Blanco, ed. 1, 97; ed. 2, $72=$ Quamoclit vulgaris Choisy.! T., Agoho.

Convolvulus nil Linn., Blanco, ed. 1, 92; ed. 2, 68 = Ipomøa nil (Linn.), Roth.! Erroneously reduced by Villar to Ipomœa hederacea Jacq.

Convolvulus repens Blanco, ed. 1, 92; ed. 2, $68=$ Ipomoea reptans (Linn.) Poir.! T., P., Cangcong. V., Tancong.

Convolvulus pes-caprae Linn., Blanco, ed. 1, 88; ed. 2, 65=Ipomøa pes-caprae (Linn.) Roth.! T., B., Catang catang, Lagayrai, Lampayong Bagasua, Camigang, Daripay, Tagaray, Arodayday, Lambayong. I., Lambayong.

Convolvulus batatas Linn., Blanco, ed. 1, 93; ed. 2, 68=Ipomøa batatas (Linn.) Lam.! T., Camoti. 
Chironia capsularis Blanco, ed. 1, 102 ; Chironia lanosanthera Blanco, ed. 2, $71=$ Ipomøa nymphofolia (Blume) Hallier.! Erroneously reduced by Villar to Ipomœa peltata Choisy. T., Bulacan.

* Convolvulus distillatorius Blanco, ed. 1, 95; ed. 2, 70. This species was reduced by Villar to Ipomøa campanulata Linn., which is certainly an error. Probably a species of Erycibe. V., Bulacan, Buracan.

Convolvulus maximus Blanco, ed. 1, 91; ed. 2, 67, non Linn. = Operculina turpethum S. Manso.!

Convolvulus catharticus Blanco, ed. 1, 94; Convolvulus longiflorus Spreng., Blanco, ed. 2, 69=Ipomoea glaberrima Boj.! Reduced by Villar to Ipomoca longiflora R. Br. T., Bulacan.

Convolvulus colubrinus Blanco, ed. 2, 66. Reduced by Villar to Ipomœa muricata Jacq., which is probably correct. Introduced and cultivated.

Ipomoea pes-tigridis Linn., Blanco, ed. 1, 97 ; ed. 2, 71.!

Ipomoea hepaticifolia Blanco, ed. 2, 72, non Linn. Reduced by Villar to Ipomœa angustifolia Jacq., but this is certainly an error. Probably a form of Merremia umbellata var. orientalis Hallier f. Blanco's specimens were from Parañaque, near Manila, flowering in January.

Convolvulus paniculatus Linn., Blanco, ed. 1, 96; ed. 2, $70=$ Ipomœa paniculata (Linn.) R. Br.! T., Puntas puntas.

Convolvulus dentatus Blanco, ed. I, 89; ed. 2, 66, non Vahl. = Ipomøa blancoi Choisy.!

Polemonium obscurum Blanco, ed. 1, 103; ed. 2, 75. Reduced by Villar to Lepistemon flavescens Blume, which is probably correct. Blanco's specimens were from Bauang, Tayabas, and from Santiago, Ilocos Sur, flowering in January.

Convolvulus reniformis Roxb., Blanco, ed. 1, 91; ed. 2, $67=$ Merremia emarginata Hallier.! Reduced by Villar to Lepistemon reniformis Hassk. T., Bato bato. I., Cupit cupit.

Convolvulus hederaceus Blanco, ed. 1,90 ; ed. 2, 66, non Linn. $=$ Hewittia bicolor Wight.!

Evolvulus linifolius Blanco, ed. 1, 221; ed. 2, 156. Reduced by Villar to Evolvulus alsinoides Linn., which is probably correct.

* Porania volubilis Blanco, ed. 1, 88; ed. 2, 64. Considered by Villar to be identical with Porania volubilis Burm., which may be correct. Blanco's specimens were from Cebu. V., Bulacan.

* Convolvulus valerianoides Blanco, ed. 1, 90; Convolvulus boerhaavoides ed. 2,67. Reduced by Villar to Breweria, as a distinct species. B. valerianoides (Blanco) F.-Vill. This species is known only from Blanco's description, his specimens being from Santiago Point, Province of Batangas.

\section{SOLANACEAE.}

Solanum lycopersicum Linn., Blanco, ed. 1, 134; ed. 2, $96=$ Lycopersicum esculentum Mill.! T., Camatis, Tomates. 
Solanum nigrum Linn., Blanco, ed. 1, 134; ed. 2, 96.! T., Cunti, Onti, Gamagamatisan. V., Lagpacum, Bolagtob, Lubilubi. C., Cuti, Lubilubi.

Solanum mauritianum Blanco, ed. 1, 134; ed. 2, 96, non Scop. = Solanum verbascifolium Linn.! V., Noog noog.

Solanum zeylanicum Blanco, ed. 1, 136; ed. 2, 97, non Scop. = Solanum ferox Linn.! T., T'along gubat, T'arambolo.

Solanum melongena Linn., Blanco, el. 1, 135; ed. 2, 96.! T., Talong.

Solanum coagulans Blanco, ed. 1, 135; ed. 2, 97, non Jacq. Reduced by Villar to solanum sanctum Linn., but is probably only a variety of Solanum melongena Linn. T., Tarumbulo, Tangantangan.

Solanum sinense Blanco, ed. 1, 137; Solanum tuberosum Linn., Blanco, ed. 2,97 . The latter name is correct.!

Physalis peruviana Linu., Blanco, ed. I, 138; ed. 2, 98.! T., Potocan. Physalis angulata Linn., Blanco, ed. 1, 138; ed. 2, 99.! I., Tuttullacac. Physalis pubescens Linn., Blanco, ed. 1, 138; ed. 2, 98.!

* Solanum serratum Blanco, ed. 1, 136; ed. 2, 97. Reduced by Villar to Physalis indica Linn., which is probably correct. Blanco's specimens were from Pasig, Province of Rizal, flowering in January.

Capsicum minimum Roxb., Blanco, ed. 1, 133; ed. 2, 95.! T., Pasitis.

Datura metel Blanco, ed. 1, 98; ed. 2, 72, non Limn., = Datura fastuosa Linn., var.! Villar considers that Blanco's species is the same as Datura alba Nees. P., T., Talamponai. V., Tavbibung.

Datura fastuosa Linn., Blanco, ed. 1, 100; ed. 2, 73.! T., Talamponai na itim.

Nicotiana tabacum Linn., Blanco, ed. 1, 101 ; ed. 2, 74.! Sp.-Fil., Tabaco.

* Nicotiana fruticosa Linn., ? Blanco, ed. 2, 74. V. frutescens Blanco, ed. 1, 101. This species may be the same as the form described by Linnaeus. Blanco's specimens were from the pueblo of San Jose, Batangas.

* Nicotiana pusilla Blanco, ed. 1, 100; ed. 2, 74. Reduced by Villar to Nicotiana rustica Linn., but this reference is very doubtful. Blanco's specimens were from a garden in Manila.

\section{SCROPHUIARIACEAS.}

Stemodia ruderalis Blanco, ed. I, 498; ed. 2, 348, non Linn. = Lindenbergia philippensis (Cham.) Benth.!

Tala odorata Blanco ed. 1, 485); ed. 2, 338. Reduced by Villar to Limnophila menthastrum Benth., but certainly the same as Limnophila roxburghii G. Don.! T., Trala, Taramhampan. P., Talatala. I., Taratara.

* Diceros stoloniferus Blanco, 'd. 2, 349. Reduced by Villar to Limnophila repens Benth., which is ecrtainly an error. May be Limnophila conferta Benth. Sp.-Fil., Oregano. 
Calytriplex obovata Ruiz. et l'ar.. 13lanco, el. 2, 361. Thunbergia stolonifera Blaneo, ed. $1,517=$ Herpestes monnicre II. 13. K.! T., Olasumang aso.

Legazpia triptera Blinco, ed. 2, 339 = Torenia polyyonoides Benth.!

Mimulus violaceus Blanco, ed. 2, 357 = Torenia peduncularis Benth.!

* Vandellia multiflora Blaneo, ed. 1, 505, non Don. Reduced by Villar to Torenia asiatica Linn., which ma be correct. A small plant, flowering in October. This species is not included in the second edition.

* Torenia paniculata Blanco, ed. 1, 486; ed. 2, 339. This species is retained by Villar as distinct, which must be considered doubtful, as Blanco states that the plant is very common, although at present it is known only from Blaneo's description.

Vandelia soriana Blanco, ed. 1, 506; Torenia soriana Blanco, ed. 2, 340. Retained by Villar as a distinct species, but is apparently the same as Vundelia peduncularis Benth. Blanco's specimens were from Malinta and Guadalupe, near Manila, flowering in October.

Kyrtandra personata Blanco, ed. 1, 18; Cyrtandra personata Blanco, ed. 2, 13. Reduced by Villar to Bonnaya brachiata Link et Otto, which is probably correct.

Gratiola hyssopioides Blanco, ed. 1, 11; ed. 2, 8, non Lim. Reduced by Villar to Bonnaya reptans spreng., which is probably correct. Flowering in January.

Kyrtandra serrata Blanco, ed. 1, 18. Reduced by Villar to Bonnaya veronicaefolia Spreng., which may be correct. This species is not included in the second edition.

Kyrtandra capsularis Blanco, ed. 1, 17; Cyrtandra glaberrima Blanco, ed. 2,12 . Certainly the same as the preceding.!

Scoparia dulcis Linn., Blanco, ed. 1, 55; ed. 2, 37.! T., Chachachachahan.

\section{OROBANCHACEAE.}

Aginetia indica Roxb., Blanco, ed. 2, 342.! T., Dagatan.

\section{GESNERIACEA.}

* Hydrocotyle monopetala Blanco, ed. 1, 213; Ophiorhiza triandra Blanco, ed. 2, 65. This species was reduced by Villar to Epithema, as a distinct species, Epithema triandrum (Blanco) F.-Vill. If a species of Epithema, possibly the same as Epithema benthami Clarke. A small plant, flowering in December.

* Kyrtandra aristata Blanco, ed. 1, 18; Cyrtandra aristata Blanco, ed. 2, 13. Referred by Villar to Didymocarpus, as a distinct species $D$. aristata (Blanco) F.-Vill., which reference must be considered doubtful. Blanco's specimens were from Malinta, near Manila, flowering in October. Probably not a species of this family.

$21896-5$ 


\section{BIGNONIACEAE.}

Bignonia quadripinnata Blanco, ed. 1, 499; ed. 2, $349=$ Oroxylum indicum (Linn.) Vent.! T., Pincapincahan, Pincapinca, Taghilao, Abangabang.

Bignonia spathacea Linn., Blanco, ed. 1, 499; Spathodea luzonica Blanco, ed. 2, $350=$ Dolichandrone spathacea (Linn.) K. Sch.! T., Tue.

Millingtonia quadripinnata Blanco, ed. 1, 499; ed. 2, 351= Stereospermum quadripinnatum (Blanco) F.-Vill.! T., Baticulin. V., Ansohan.

Millingtonia pinnata Blanco, ed. 1, 501; ed. 2, 351 = Stereospermum pinnatum (Blanco) F.-Vill.! T., Banaibanai, Botong manoc.

Crescentia trifolia Blanco, ed. 1, 489; ed. 2, $343=$ Crescentia alata H. B. K.! Sp.-Fil., Hoya cruz.

\section{PEDALIACEAE.}

Sesamum indicum Linn., Blanco, ed. 1, 507; ed. 2, 353.! T., Linga. V., Longa. P., Langis.

\section{ACANTHACEAE.}

Thunbergia subsagittata Blanco ed. 1, 518; Thunbergia fragrans Blanco, ed. 2, 360. Reduced by Villar to Thunbergia javanica Gaertn., but is probably Thunbergia fragrans Roxb.

Elytraria amara Blanco, ed. 2, $8=$ Elytraria crenata Vahl.!

* Antirrhinum molle Blanco, ed. 1, 503; ed. 2, 353. Reduced by Villar to Hygrophila undulata Nees, which is certainly an error.! Blanco's specimens were from Malinta, near Manila, a common plant flowering in January.

Antirrhinum comintanum Blanco, ed. 1, 502; ed. 2, 352=Hygrophila salicifolia Nees.! T., Mamitic.

Ruellia uliginosa Blanco, ed. 1, 494; ed. 2, 346, non Linn. = Blechum brownei Juss.! T., Sapinsapin, Dayang. P., Torrecilla, Calaboa.

* Ruellia repens Blanco, ed. 1, 493; ed. 2, 345, non Linn. Reduced by Villar to Hemigraphis, as a distinct species, Hemigraphis repens (Blanco) F.-Vill. Known only from Blanco's description, whose specimens were from Cebu. V., Palad palad.

Acanthus doloariu Blanco, ed. 1, 487; Acanthus ilicifolius Linn., Blanco, ed. 2, 341. The latter name is correct.! T., Dilivario, Dolariu, Tingloi, Laguiolaguio. V., Titio. P., Dulauari.

Barreliera cristata Blanco, ed. 1, 492; ed. 2, $344=$ Barleria cristata Linn.! Sp.-Fil., Flor de campana.

Barreliera prionitis Blanco, ed. 1, 491; ed. 2, $343=$ Barleria prionitis Linn.! T., Cocong manoc. 
Justicia gandarussa Blanco, ed. 1, 14; ed. 2, $10=$ Pseuderanthemum bicolor (Schrk.) Radlk.! T., Cinco llagas, Silisilihan, Limang sugat. V., Mopio, Maladosos, Panaptun. P., Alyopyop, Mandalusa.

* Ruellia secunda Blanco, ed. 1, 495; ed. 2, 346=Lepidagathis secunda (Blanco) Nees. A species known only from Blanco's description, but which is probably identical with Lepidagathis luzona Nees.

* Dianthera americana Blanco, ed. 1, 16, non Linn.; Dianthera ciliata Blanco, ed. 2, 12. Reduced by Villar to Justicia mollissima Nees, which is a synonym of Justicia simplex Don., and a species as yet not reported from the Philippines. Blanco's species is, possibly, a form of Justicia procumbens Linn. A plant a foot high, common in Malinta.

Justicia dalaora Blanco, ed. 1, 14; ed. 2, 10. Reduced by Villar to Dianthera (Justicia) dichotoma (Blume) Clarke, which is probably correct. V., Dalaora.

Justicia nasuta Linn., Blanco, ed. 1, 14; ed. 2, 10. Considered by Villar to be the Linnean plant $=$ Rhinacanthus communis Nees. T., Tagactagac.

Justicia picta Linn., Blanco, ed. 1. 12; ed. 2, 9= Graptophyllum pictum (Linn.) Griff.! (Graptophyllum hortense Nees.) T., Moradong maputi, Balasbas. V., Balasbas, Antolang, San Francisco.

Justicia ecbolium Blanco, ed. 1, 13; ed. 2, 10, non Linn. = the preceding.! The variety with purplish leaves. T., Morado, Ternate, Balasbas. V., Balasbas. P., V., Hojas moradas, Balasbas malomay, Yovas, Ataiatai.

* Ruellia contorta Blanco, ed. 1, 496; ed. 2, 347. Reduced by Villar to Peristrophe as a distinct species, $P$. contorta (Blanco) F.-Vill., a species known only from Blanco's description. Blanco's specimens were from Bauang, Province of Batangas, flowering in February. T., Sapinsapin.

Justicia viridis Blanco, ed. 1, 15; ed. 2, 11, non Forsk. = Hypoestes malaccanus Wight.!

\section{VERBENACEAE.}

Lantana viburnoides Blanco, ed. 2, 345, non Vahl. = Lantana camara Linn.!

Verbena capitata Forsk., Blanco, ed. 1, 19; ed. 2, 14 = Lippia nodiflora (Linn.) Rich.! T., Chachachachahan.

* Callicarpa americana Blanco, ed. 1, 517; ed. 2, 360, non Linn. = Callicarpa blancoi Rolfe.! Reduced by Villar to Callicarpa bicolor Juss., and certainly closely related to that species. 'T., Palis, Tubang dalag.

Tectona grandis Linn. f., Blanco, ed. 1, 130; ed. 2, 92.! Sp.-Fil., Teca, Ticla. V., Dalondon, Yate, Calayate. 
* Diospyros tectona J3lanco, ed. 2, 609. This name is published in the index to native names, under Dalandon, without description. Villar reduces it to Tectona hamiltoniana Wall. The name should be discarded.

* Premna serratifolia Blanco, ed. 2, 342, non Linn. Reduced by Villar to Premna foetida Reinw., which is undoubtedly an error.

Premna odorata I3lanco, ed. 1, 488; ed. 2, 341. Erroneously reduced by Villar to Premna pubescens Blume, a species that does not extend to the Philippines. Blanco's species is certainly identical with Premna vestita Schaver, which is a much later name. 'T., Alagao. V., Adgao, Pamuhat. P., Tanglay maloto. I., Anobran.

* Premna cordata Blanco, ed. 1, 489; Premna tomentosa Blanco, ed. 2, 342, non Wall. Considered by Villar to be identical with Premna tomentosa Wall., but this is certainly an error. T., Malaapi.

Premna nauseosa Blanco, ed. 1, 489; Premna integrifolia Blanco, ed. 2, 342. A good species, the first name being the correct one. Erroneously reduced by Villar to Premna mucronata Roxb.

Gmelina asiatica Blanco, ed. 1, 492; ed. 2, 344, non Linn. = Gmelina villosa Roxb.! T., V., Bagaboboi, Balabalayan.

Gmelina inermis Blanco, ed. 1, 493; ed. 2, 345 = Gmelina asiatica Linn. ?, or a form of the preceding.

Vitex repens Blanco, ed. 1, 513; ed. 2, $358=$ Vitex ovata Thunb. (Vitex trifolia Linn. f. var. oborata Benth.) T., Lagunding gapang.

Vitex trifolia Linn. f., Blanco, ed. 1, 513; ed. 2, 358.! T., Lagundi. V., Gapasgapas. I., Danglay.

Vitex leucoxylon Blanco, ed. 1, 516; ed. 2, 359, non Linn. Reduced by Villar to Vitex negundo Linn., which is probably correct. T., Lagundi, Molavin.

Vitex altissima Blanco, ed. 1, 516; ed. 2, 359, non ? Linn. = Vitex littoralis Decne.! T., Molavin, Lagundi.

Vitex Iatifolia Blanco, ed. 1, 514; ed. 2, 358 = Vitex pubescens Vahl.! T., Molauin, Hamaraon, Bulaon.

* Vitex geniculata 13lanco, ed. 1, 514; ed. 2, 299. A species closely related to Vitex littoralis Decne, but perhaps distinct. T., Molavin.

Clerodendron capsulare Blanco, ed. 1, 509; ed. 2, 355=Clerodendron inerme R. Br.!

Volkameria grandiflora Blanco, ed. 1, 512; ed. 2, 357 = Clerodendron macrostegium Schauer. T., Iulapotocan, Bagauac. J., Agboligan, Nacboligan.

Clerodendron fortunatum 3laneo, ed. 1, 508; ed. 22, 354, non Linn. = Clerodendron blancoi Naves.! Reduced by Villar to Clerodendron infortunatum Gaertn. T., c'asopanguil gubat. 
Volkameria inermis Blanco, ed. 1, 511, non Limn; Bolkameria casopanguil Blanco, ed. 2, $356=$ clerodendron intermedium ('ham.! T., Casopanguil, Laroan, Anito, Macalalauang, Iginga. V., Asuangai, I'acapis, Colocolog, Alocasoc.

Ligustrum quadriloculare Blaneo, ed. 1,10 ; ed. 2, 7 . This specio's is the same as Clerodendron navesiunum Vidal (Clcrodendron blancoanum F.-Till.) but the species is very near if not identicil with Clerodendron longiflorum Decne. T., Balicturin.

Litsea luzonica Blanco, ed. 2, $284=$ Symphorema luzonicum (Blanco) F.-Vill.! (Symphorema luzoniense Vidal.) This species is described in the first edition under the native name only. P., Balaibai.

Avicennia nitida Blanco, ed. 1, 504, non Jacq.; Avicennia tomentosa R. Br., Blanco, ed. 2, 353 = Avicennia officinalis Linn.!

\section{LABIAT.F.}

Ocimum americanum 13lanco, ed. 1, 480; ed. 2, 335, non Linn. = Ocimum basilicum Limn.! 'T., P., Solasi. V., Bonac.

Ocimum citriodorum Blanco, ed. 2,591 = the preceding species.!

Ocimum album Blanco, ed. 1, 479, non Linn.; Ocimum virgatum Blanco, ed. 2, 334, non Linn. = Ocimum gratissimum linn.! T., Locoloco. V., Coloncogon. P., Locoloco.

Ocimum sanctum Linn., Blanco, ed. 1, 480; ed. 2, 334.! T., Balanoi.

Ocimum flexuosum Blanco, ed. 1, 480; ed. 2, 334, non Linn. = the preceding,! the purple-stemmed form. 'T., Balanoi.

Ocimum tenuiflorum Blanco, ed. 1, 481; ed. 2, 335= Mcschosma polystachyum Benth.!

Coleus suganda Blanco, ed. 1, 483; ed. 2, 337. Reduced by Villar t: Coleus aromaticus Benth., which is probably correct. Sp.-Fil., Orcgaıo. T., Sruganda.

* Coleus pumilus Blanco, ed. 1, 482; ed. 2, 336. Reduced by Villar to Coleus acuminatus Benth., which may be correct. Blanco's specimens were from Pasig, Province of Rizal, flowering in October. T., Malamayana.

Coleus grandifolius Blanco, ed. 1, 482; ed. 2, 336. Reduced by Villar to Colcus atropurpureus Benth., which is probably correct. T., V., P., Mayana, Maliana, Badiara, Marayapa.

Pycnanthemum elongatum Blanco, ed. 2, $333=$ Hyptis spicigera Lam.!

Thymus virginicus Blanco, ed. 1, 478, non Linn.; Pycnanthemum decurrens Blanco, ed. 2, $333=$ Hyptis capitata Jacq.! T., Combarcombaran, Lingalingahan.

Thymus biserratus Blanco, ed. 1, 478; Pycnanthemum subulatum Blanco, ed. 2, $333=$ Hyptis brevipes Poir.! T., Combarcombaran.

Marrubium indicum 13lanco, ed. 1, 477; ed. 2, 332, non Burm. = Byptis suaveolens Poir.! T., Soob cabayao. 
Mentha cablin Blanco, ed. 1, 472; Mentha auricularia Blanco, ed. 2, 329, non Linn. = Pogostemon cablin (Blanco) Benth.! T., Cablin, Carlin. V., Cadlom, Catluen, Cadlin. P., Cablin.

Mentha crispa Blanco, ed. 1, 474; ed. 2, 330, non Linn. = Mentha arven . sis Linn.! Sp.-Fil., Yerba buena.

Salvia violacea Blanco, ed. 2, 14, non Retz. et. Pav. = Salvia plebeia R. Br.!

Rosmarinus officinalis Linn., Blanco, ed. 1, 20; ed. 2, 15.! Sp.-Fil., Romero.

Phlomis alba Blanco, ed. 1, 474; ed. 2, 330, non Forsk. = Anisomelis ovata R. Br.! T., Talingharap.

Stachys artemesia Lour., Blanco, ed. 1, 476; ed. 2, $331=$ Leonurus sibiricus Linn.! T., Camariang songsong.

Phlomis zeylanica Blanco, ed. 1, 475; ed. 2, 331, non Linn. Reduced by Villar to Leucas aspera Spreng., but certainly is Leucas linifolia Spreng.! T., Pansipansi, Solasolasihan, Carucansoli. V., Pansipansi, Paipaisi.

\section{PLAN'TAGINACEA.}

Plantago crenata Blanco, ed. 1, 56; Plantago media Blanco, ed. 2, 38, non Linn. Reduced by Villar to Plantago erosa Wall., which is a synonym of Plantago major Linn. Probably correctly referred. Flowering in February. T., Lantin.

\section{NYCTAGINACEAS.}

Mirabilis longiflora Blanco, ed. 1, 77; ed. 2, 57, non Linn. = Mirabilis jalapa Linn.! Sp.-Fil., Oracion, Diego de noche, Bella de noche. 'T., Guilalas, Suspiros.

Boerhaavia diffusa Linn., Blanco, ed. 1, 8; ed. 2, $6=$ Bocrhaavia repens Linn.! T., Paanbalivis. I., Tabtabocol ti Nuang.

Pisonia aculeata Linn., Blanco, ed. 1, 195; ed. 2, 137.! T., Digquit. digquit. I., Puriquet. T., Panacla.

Cordia olitoria Blanco, ed. 1, 123; ed. 2, 88. Reduced by Villar to Pisonia inermis Forst., which is cited as a synonym of Pisonia alba Spanoghe. A species rather commonly cultivated in Manila, but rarely producing flowers. T., Maluco, Coles maluco.

* Buginvillea racemosa Blanco, ed. 1, 307; ed. 2, 214. Reduced by Villar to Pisonia excelsa Blume, which is certainly an error. Blanco's specimens were from Angat, Province of Bulacan, no native name given.

* Cedrota guianensis Blanco, ed. 2, 213, not Ræusch. Reduced by Villar to Pisonia umbellifera Seem., which is the same às Pisonia excelsa Blume. Blanco's specimens were from Cebu. V., Tac-an. 


\section{MWARANTACET.}

Celosia baccata Retz., Blanco, ed. 1, 193; Deeringia celosioides R. Br., Blanco, ed. 2, 135. The latter name is correct. T., Hagorilis. V., Hanlilimocon.

Celosia cristata Linn., Blanco, ed. 1, 191; Celosia coccinea Linn., Blanco, ed. 2, 134. The former name is correct. T., Palongpalongan.

Celosia argentea Limn., Blanco, ed. 1, 192; ed. 2, 135.! T., Cadayohan, Quindayohan.

* Celosia bicolor Blanco, ed. 1, 191; Celosia glauca Blanco, ed. 2, 13j, non Rottl. Reduced by Villar to Celosia philippica (Weimm.) Steul.

Amarantus spinosus Linn., Blanco, ed. 1, 710; ed. 2, 491.! T., Quilites, Orayi. P., Ayantoto. V.; Calites, Tililes, Harum, Orayi, Bayangbayang. I., Cuanton.

Amarantus mangostanus Linn., Blanco, ed. 1, 711; ed. 2, 492. Probably correct, although Villar reduces Blanco's species to Amarantus melancholicus Linn., which is a synonym of Amarantus gangeticus Linn. T., Halon.

Illecebrum lanatum Linn., Blanco, ed. 1, 190; Celosia lanata Linn.: Blanco, ed. 2, 134 = Aerua lanata (Linn.) Juss.!

Achyranthes aspera Linn., Blanco, ed. 1, 188; ed. 2, 133.! T., Hangor, Hangot, Docotdocot, Libai. P., Angud. V., Hangor.

Achyranthes villosa Blanco, ed. 1, 189; ed. 2, 134, non Forsk. Reduced by Villar to Alternanthera denticulata R. Br., probably however only a form of the common Alternanthera sessilis R. Br. T., Bonga bonga.

Gomphrena globosa Linn., Blanco, ed. 1, 198; ed. 2, 139.! T., Buquingan.

\section{CHENOPODIACEAE.}

Chenopodium ambrosioides Linn., Blanco, ed. 1, 200; ed. 2, 140.! T., V., P., Aposotis.

Basella rubra Linn., Blanco, ed. 1, 215; ed. 2, 151 = Basella alba Linn.! T., Libato. I., Ilaibaquir.

Basella lucida Linn., Blanco, ed. 1, 151; ed. 2, $273=$ the preceding.! T., Grana.

Gomphrena volubilis Blanco, ed. 1, 199; ed. 2, $140=$ Anredera scandens Juss.!

\section{POLYGONACEAE.}

Polygonum stoloniferum Blanco, ed. 1, 314; ed. 2, 219. Reduced by Villar to Polygonum barbatum Linn., var. vulgare Meisn., which is probably correct. T., Subsuban. P., Canubsuban.

* Polygonum bellardi Blanco, ed. 1, 314; ed. 2, 219, non Boiss. Reduced by Villar to Polygonum orientale Linn., which is probably an error. Blanco's specimens were from Taguig, Province of Rizal, flowering in March. T., Subsuban. P., Canucsuban. 
Rheum muricatum 13lanco, ed. 1, 327; Rumex muricatus Blanco, ed. 2, $195=$ Rumex maritimus Linn.! Blanco's specimens were from cultivated plants.

\section{NEPENTHACEA.}

Nepenthes alata Blanco, ed. 1, 805; ed. 2, 555. A good species.! Nepenthes ventricosa 13lanco, ed. 1, 807 ; ed. 2, 556. A good species.!

\section{CY'TINACEAE.}

Rafflesia philippinensis 13lanco, ed. 2, 565; Rafflesia lagascae Blanco, ed. $2,595=$ Rafflesia manillana Teschem.!

\section{ARISTOLOCHIACEAE.}

* Aristolochia sericea Blanco, ed. 1, 283; ed. 2, 198. Reduced by Villar to Bragantia corymbosa Griff., which may be correct, although the latter species is at present not known from the Philippines. Blanco's specimens were from Agoo, Province of Union.

* Aristolochia indica Blanco, ed. J, 282; ed. 2, 197, non ? I. Considered by Villar to represent the linnean species, but probably only a form of Aristolochia tagala ('ham. 'T., T'imbagan, Malaubai.

Aristolochia subsagittata Blanco, ed. 1, 283; ed. 2, $197=$ Aistolo hia tagala C'ham.! T., T'imbangan, Timbangantimbangan, Malaubi. I., Taointaoin.

\section{PIPERACEA.}

Piper parvifolium Blanco, ed. 1, 23; ed. 2, 17. Reduced by Villar to Piper caninum. A. Dietr., which is probably correct. T., Sabia.

* Piper obliquum Blanco, ed. 1, 22; ed. 2, 16. Reduced by Villar to Piper corylistachyon ('. I)C. If this is correct, Blanco's name is the earlier. T., V., Litlit, Litbit, Saog, Sangilo. B., Nopau.

Piper betel Blanco, ed. 1, 22; ed. 2, $16=$ Piper betle Linn.! T., B., Itmo, Mamin. V., Buyo, Mamon. P., Samat.

Piper nigrum Ijinn., Blanco, ed. 1, 21 ; ed. 2, 16.! Sp.-Fil., Pimienta. T., Malisa.

* Piper anisumolens Blanco, ed. 1, 23; Piper anisodorum Blanco, cd. 2, 16. Reduced by Villar to P'iper marginatum Jacq., an American species, which is probably correct. T., Buyo de anis.

\section{CHLORANTHACEA.}

Chloranthus inconspicuus Blanco, ed. 2, 54, non Swartz. Reduced by Villar to Chloranthus officinalis Blume, which may be correct. Chloranthus brachystachyus 3lume, is, however, the more common species in the Philippines. 


\section{MYRINTIC ACE.t.}

Myristica luzonica Blanco, ad. 1, 66t; ed. 2, 462; $463=$ Myristica philippinensis Jaln.! T., Talangtalang, Anis moscada, Anis cahoi, Duguan.

* Sterculia glomerata Blanco, ed. 1, 764; ed. 2, 525. This species is reduced by Villar to Myristica corticosa IIook. f. et Thoms., a species that does not extend to the Philippines, considered by Warburg to be possibly the same as Knema heterophylla (F.-Vill.) Warb. T., Hindurugo.

* Sterculia decandra 13lanco, ed. 1, 766; ed. 2, 525. Reduced by Villar to Myristica intermedia Blume, a species that does not extend to the Philippines. Probably a species of Myristica. Blanco's specimens were from Balanga, Province of Bataan. T., Banabanalo.

\section{LAURATEFE.}

* Laurus martinicensis Blanco, ed. 1, 317; ed. 2, 223, non aliorum. Reduced by Villar to Beilschmiedia madang Blume, which is certainly an error. Probably a species of Lauracea, but the genus is doubtful. A tree flowering in December. T., Dinglas.

* Salgada laurifolia Blanco, ed. 2, 221. Reduced by Villar to Eusideroxylon borncense ' $\mathrm{T}$. et 13 ., which must be considered very doubtful. Blanco's specimens were from Angat, Province of Bulacan.

* Laurus cassia Blanco, ed. 1, 317; ed. 2, 223, non Linn. Considered by Villar to represent Laurus cassia Burm, and by Villar reduced to a variety of Cinnamomum zeylanicum Breyn. Certainly erroneously referred. Blanco's specimens were from Balanga, Province of Bataan T., Samilin.

Laurus cinnamomum 13lanco, ed. 1, 319; ed. 2, 225, non Linn. Referred by Villar to Cinnamomum burmanni Nees, which may be correct, as Blanco's specimens were from a cultivated plant.

Laurus culilaban Blanco, ed. 1, 315; ed. 2, 222, non aliorum. This species was reduced by Villar to Cinnamomum pauciftorum Nees, which is certainly an error, as that species does not extend to the Philippines. Probably identical with the form described by Vidal as Cinnamomum mercadoi. T., Calingag, Macalingag. V., Calingag, Calinga. P., Calingad. I., Candaroma.

Laurus persea Linn., Blanco, ed. 2, $224=$ Persea gratissima Gaertn., an American species, cultivated. Blanco's specimens were from Santa Ana, a suburb of Manila.

Sebifera glutinosa Blanco, ed. 1, 819; ed. 2, 566, non Lour. Reduced by Villar to Litsca chinensis Lam., which is probably correct. 'T., P'usopuso. I., Sablut. 
Sebifera balongai Blanco, ed. 1, 820; ed. 2, 567. Reduced by Villar to Litsea litoralis Blume, but Vidal refers Litsea litoralis F.-Vill. to Litsea chinensis Lam. Probably only a form of the latter species. T., Balongai.

* Olax baticulin Blanco, ed. 2, $586=$ Litsea obtusata F.-Vill.? Impossible to determine definitely if Blanco's species is the same as Villar's. T., Baticulin.

Laurus lanosa Blanco, ed. 1, 318; ed. 2, 224. Reduced by Villar to Litsea villosa Blume, which may be correct. T., V., Batobato.

* Ajovea malabonga Blanco, ed. 1, 233; Laurus hexandra Blanco, ed. 2, 222, non aliorum. Reduced by Villar to Iteadapne confusa Blume, which must be considered doubtful, as the latter species is unknown from the Philippines. A tree flowering in August. T., Malabonga.

Cassytha filiformis Linn., Blanco, ed. 1, 321; ed. 2, 226.! T., Malabohoc. Hernandia sonora Blanco, ed. 1, 689; ed. 2, 478, non Linn. = Hernandia peltata Meissn.! T., Colongcolong.

\section{THY MELAEACET.}

* Daphne indica Blanco, ed. 1, 309; ed. 2, 215, non ? Linn. Considered by Villar to represent the Linnean species, probably, however, the form described as Wickstroemia viridiflora Meissn. T., Salago, Malasampaga.

Daphne foetida Linn. ? Blanco, ed. 1, 308; ed. 2, 214. Certainly only a form of the preceding.! T., Salago, Malasampaga.

* Daphne aquilaria Blanco, ed. 1, 310; ed. 2, 216. Reduced by Villar to Wickstroemia ovata Mey. Vidal, however, states that Wickstroemia ovata F.-Vill., is the same as W. indica Mey. I., Arandon.

Dais laurifolia Blanco, ed. 1, 375; ed. 2, 263, non Jacq. = Phaleria perrottetiana (Decne.) F.-Vill.!

\section{ELAEAGNACEAE.}

Elaeagnus angustifolia Blanco, ed. 1, 74; ed. 2, 53, non Linn. = Elaeagnus latifolia Linn.! T., Alingaro.

\section{LORANTHACEAE.}

Lonicera symphoricarpos Blanco, ed. 1,161 ; Loranthus philippinensis Cham. et Schlecht., Blanco, ed. 2, 164. The second name is probably correct. T., Dapo.

* Loranthus pauciflorus Blanco, ed. 1, 235; Lonicera tomentosus Blanco, ed. 2, 164, non aliorum. Considered by Villar to be a distinct species and retained under the former name. Blanco's specimens were parasitic on spondias. 'T., Dapo sa cahoy. I., Binbinguay. 
* Hillia longiflora Blanco, ed. 1, 235; ed. 2, 165. Reduced by Villar to Loranthus ampullaceus Linn., which is probably an error, as the latter species is not found in the Philippines. Blanco's specimens were parasitic on Mangifera altissima Blanco, a tree known to the natives as pajo. Flowering in April. T., Dapo sa pajo.

* Brabejum ? caliculatum Blanco, ed. 2, 39. Reduced by Villar to Loranthus, as a distinct species, Loranthus blancoanus F.-Vill. Possibly a species of Loranthus. Blanco's specimens were from Cebu. V., Malabachao.

Fusanus ? parasitus Blanco, ed. 2, 53. Reduced by Villar to Viscum orientale Willd., which is probably correct. Blanco's specimens were parasites on a species of Pterocarpus in Angat, Province of Bulacan, flowering in February.

\section{EUPHORBIACE $A$.}

Euphorbia dulcis Blanco, ed. 1, 412; ed. 2, 287, non Linn. Reduced by Villar to Euphorbia laevigata Vahl. = Euphorbia atoto Forst.!

Euphorbia parannaquensis Blanco, ed. 2, $286=$ Euphorbia serrulata Reinw.!

Euphorbia capitata Lam., Blanco, ed. 1, 411; Euphorbia hirta Linn., Blanco, ed. 2, $286=$ Euphorbia pilulifera Linn.! T., Batobatonis, Sayican, Gatasgatas, Golandrina. V., Gatasgatas, Buyayava, Tavava, Bovi. P., Malismalis, Sisiohan, Bolobtones, Magatas.

Euphorbia pentagona Blanco, ed. 1, 413; ed. 2, 287, non Haw. Reduced by Villar to Euphorbia neriifolia Linn., which is probably correct. B., T., P., Sorosoro, Sorog sorog, Bait, Lengua de perro. I., Carambuaya.

Euphorbia tirucalli Linn., Blanco, ed. 1, 412; ed. 2, 287.! T., Catuit. Sp.-Fil., Consuelda.

Clutia stipularis Linn., Blanco, ed. 1, 818; ed. 2, 564 = Bridelia stipularis Blume.! T., Hingongoto, Lobalob. I., Calondagui, Carabaui.

Gluta orgyalis Blanco, ed. 2, 451 = Cleistanthus orgyalis (Blanco). (Cleistanthus blancoi Rolfe, Journ. Linn. Soc. Bot. 21: 315; Vidal, Rev. Pl. Vasc. Filip. 234.) Erroneously reduced by Villar to Cleistanthus ferrugineus Muell. Arg. Blanco's specimens were from Angat, Province of Bulacan, flowering in April.

Kirganelia triandra Blanco, ed. 1, 711; ed. 2, $492=$ Phyllanthus triandrus Muell. Arg.!

Kirganelia alba Blanco, ed. 1, 713; ed. 2, 494=Glochidion album (Blanco) Boerl. (Phyllanthus albus Muell. Arg.) Blanco's specimens were from Angat, Province of Bulacan. It is represented by Nos. 3162 and 3797 Merrill.

Kirganelia villosa Blanco, ed. 1, 712; ed. 2, 493, non Phyllanthus villosus Poir. = Glochidion llanosii Muell. Arg.! 
* Kirganelia nigrescens Blanco, ed. 1, 712; ed. 2, 493. Reduced by Villar to Glochidion molle Blume, which may be correct. A shrub flowering in May.

Cicca acidissima 13lanco, ed. 1, 700; ed. 2, 486= Phyllanthus distichus Muell. Arg.! T., Iba, Banquilin. V., Poras, Layohan. P., Iba.

Cicca decandra 13lanco, ed. 1, 701; ed. 2, 487 = Phyllanthus reticulatus Muell. Arg.! T., Tinatinaan, Tintatintahan, Malatinta.

Phyllanthus carolinianus 13lanco, ed. 1, 691, non Walt. Phyllanthus kirganelia Blanco, ed. 2, 480, non Willd. = Phyllanthus niruri Muell. Arg.!

Kirganelia pumila Blanco, ed. 1, 712 ; ed. 2, 493. Reduced by Villar to Phyllanthus niruri Muell. Arg., as a variety, but more probably a form of $P$. urinaria linn., or $P$. simplex Muell. Arg.

*Phyllanthus niruri Blanco, ed. 1, 690, non Linn.; Phyllanthus tetrander Jlanco, ed. 2, 480, non Roxb. Considered by Mueller to represent a distinct species, which he calls Phyllanthus blancoanus. This species is known only from Blanco's description. Blanco's specimens were from Bauang, Province of Batangas, a shrub 5 feet high, flowering in May.

Cicca pentandra Blanco, ed. 1, 701 ; ed. 2, $486=$ Fluggea obovata Wall.! T., Botolan.

Cansiera pentandra 13lanco, ed. 1, 73; ed. 2, 53 = Antidesma leptocladum genuinum Muell. Arg.! Erroneously redueed by Villar to Antidesma cumingiana Muell. Arg. T., Bignay pogo.

Cansiera grossularioides Blanco, ed. 1, 73; ed. 2, 53. Reduced by Villar to Antidesma ghaesembilla Gaertn., var. paniculatum Muell. Arg. Certainly a form of this species! T., Cabogbog.

Cansiera rheedii Blanco, ed. 1, 73; ed. 2, 52, non aliorum = Antidesma ghaesembilla (iarrtn,! the pubescent form. T., Bignai pogo.

Antidesma spicata Blanco, ed. 1, 794; Antidesma alexiteria Blanco, ed. 2, 547, non alior. Reduced by Villar to Intidesma ghresemibilla Gaertn., which is certainly correct.! T., Calamantao.

Stilago bunius Linn., Blanco, ed. 1, 782; ed. 2, 539 = Antidesma bunius (Linn.) spreng.! T., Biguai, Bugneri.

Jatropha curcas Iinn., I3lanco, ed. 1, 759; ed. 2, 522.! T., Tuba. V., Casla. I., Tavatava.

Jatropha janipha Blanco, ed. 1, 758; ed. 2, 521, non Linn. = Jatropha multifida Linn.!

Aleurites lobata Blanco, ed. 1, 756; Aleurites triloba Forst., Blanco, ed. 2, 520 = Aleurites moluccana Willd.! T., Lumban, Capili.

Aleurites lanceolata 13lanco, ed. 1, 757 ; ed. 2, 521 = the preceding.!

Aleurites trisperma Blanco, ed. 1, 755; Aleurites saponaria Blanco, ed. 2, 519. A distinct species.! T., Balocanad, Baguilumban, Calumban. V., P', Balucanag. 
Croton glandulosum Blanco, el. 1, 75t; Croton muricatum Blanco, ed. 2 , $518=$ (roton tiglium Limn.! T., Tuba, Cumaisu, Bulanti.

* Croton drupaceus Blanco. ed. 2, 519 non Roxb. Redueed by Villar to Croton luzonensis Muell. Arg., probably, however, only a form of the preceding. Blanco's specimens were from Guadalupe, near Manila, flowering in October. 'T., Balanti.

Croton variegatus Limn., Blanco, ed. 1, 751 ; ed. 2, 517=Codiacum. variegatum (Linn.) Muell. Arg.! T., Saguilala. V., Culipayang. Sp.-Fil., Buena rista, San Francisco.

Adelia acidoton Blanco. ed. 1, 815; ed. 2, 562, non Jimn. = Sumbavia rottleroides Baill.! T., Aliparo.

Jatropha manihot Limn., Blanco, ed. 1, 760; ed. 2, $522=$ Manihot utilissima Pohl.! 'T., Camoting cahoy.

* Adelia resinosa Blanco, ed. 2, 562. Reduced by Villar to Claoxylon uallichianum Mnell. Arg., which is probably an error. This species is described in the first edition under the native name Balilangouag. Blanco's specimens were from Pasig, Province of Rizal.

* Niota globosa Blanco, el. 2, 214. Reduced by Villar to Claoxylon indicum Muell. Arg., which may be correct. Blanco's specimens were from Angat, Provinee of Bulacan.

Acalypha angatensis Blanco, ed. 1, 750; ed. 2, 516. Considered by Villar to be a distinct species, probably, however, only a form of Acalypha stipulacea Klotzsch. Blanco's specimens were from Angat, Province of Bulacan, a shrub, flowering in Dccember.

Acalypha tomentosa Blanco, ed. 1, 750. Reduced by Villar to Acalypha grandis Muell. Arg., which may be correct, or it may be a form of the next species. This species is not included in the second edition.

Acalypha glandulosa Blinco, ed. 1, 749 ; ed. 2, 516, non Cav. = Acalypha stipulacea Klotzsch.!

Acalypha caroliniana Blanco, ed. 1,748 ; ed. 2,515 , non Walt. $=$ A alypha indica Linn.!

Adelia glandulosa Blaneo, ed. 1, 814. Reduced by Villar to Alchornea javcnsis Muell. Arg., which is probably correct. This species is not included in the second edition. Blanco's specimens were from Santa Maria, Province of Ilocos Sur.

* Tragia innocua Blanco, ed. 2, 479. Reduced by Villar to Alchornea villosa Muell. Arg., which is probably an error. Blanco's specimens were from Angat, Province of Bulacan, flowering in February.

* Excaecaria sicca 13lanco, ed. 1, 787; ed. 2, 542. Reduced by Villar to Alchornea mollis Muell. Arg., which is eertainly an error. Blanco states that his species is poisonous, and common along the margins of streams. T., Balanti.

* Prockia albicans 13lanco, ed. 1, 430; ed. 2, 299. Reduced by Villar to Alchornea blumeana Muell. Arg., which is certainly an error. T., Busilac. 
Adelia monoica Blanco, ed. 2, 561 = Mallotus moluccanus (Linn.) Muell. Arg.!

Adelia bernardia Blanco, ed. 1, 814, non Linn.; Adelia barbata Blanco, ed. 2, $561=$ Mallotus ricinoides (Pers.) Muell. Arg.! T., Alim, Taquip asin. V., Alum, Arum. P., Pacalcal, Vilos. C., Tapit. Sp.-Fil., Tres puntas.

* Adelia papillaris Blanco, ed. 2, 562. Reduced by Villar to Mallotus zollingeri Muell. Arg., which is certainly an error, as the latier species does not extend to the Philippines. Blanco's specimens were from Guadalupe, near Manila.

Croton lacciferum Blanco, ed. 1, 752; ed. 2, 517 = Macaranga tanarius Muell. Arg., var. tomentosa Muell. Arg.! T., Binonga, Minonga. V., P., Binonga. P., Bilau. I., Ginabang, Samac.

Croton grandifolium Blanco, ed. 1, 753; ed. 2, 518 = Macaranga mappa (Linn.) Muell. Arg.! T., Bingabing.

Ricinus communis Linn., Blanco, ed. 1, 761 ; ed. 2, 523.! T., Tangantangan, Lingasina. I., Tangantangan, Tavatavangsina.

Lumanaja fluviatilis Blanco, ed. 1, 821; ed. 2, $568=$ Homonoia riparia Lour.! T., Lomonai, Agoioi.

Excæcaria lævis Blanco, ed. 1, 788; ed. 2, $543=$ Homalanthus populneus (Geisel.) Pax.! T., Botong gubat.

* Tragia bracteata Blanco, ed. 2, 481. Reduced by Villar to Pimelodendron amboinicum Hassk., which is certainly an error. Blanco's specimens were from Angat, a shrub, flowering in February. T., Tablon.

Excæcaria agallocha Linn., Blanco, ed. 1, 786; ed. 2, 541.! T., Buta, Butabuta. V., Alipata, Lipata, Himbabao, Siac. P., Butabuta.

\section{URTICACE $A$.}

Celtis philippinensis Blanco, ed. 1, 197; ed. 2, 139. A good species.! T., Malaitmo.

Celtis lima Blanco, ed. 1, 197; ed. 2, $139=$ Trema amboinensis Blume.! T., Hanarion.

Calius lactescens Blanco, ed. 1, 698; ed. 2, 485 = Streblus asprr Lour.! T., Calios. I., Alodig.

Malaisia tortuosa Blanco, ed. 1, 789; ed. 2, 543.! A good genus and species. T., Malaisis.

Morus Iuzonica Blanco, ed. 1, 703; Broussonetia luzonensis Blanco, ed. 2, $488=$ Allaanthus luzonicus (Blanco) F.-Vill.! T., Himbabao.

Morus alba Linn., Blanco, ed. 1, 705 ; ed. 2, 489.! T., Morera.

Ficus indica Linn., Blanco, ed. 1, 681; ed. 2, 473. Reduced by Villar to Ficus saxophila Blume, but Blanco probably correctly interpreted the Linnean species. Ficus saxophila Blume is not known from the Philippines. 'T., P., Baliti. V., Dalaguit, Nonoc. 
* Ficus payapa Blanco, ed. 1, 683; ed. 2, 475. Reduced by Villar to Ficus microcarpa Limn. f., which is a synonym of Ficus retusu limn. Possibly correctly referrel. T., Payapa.

* Ficus dicarpa Blanco, ed. 1, 682; Ficus nepalensis Blanco, ed. 2, 474 non Spreng. Reduced by Villar to Ficus hamatocarpa Blume, which is a synonym of Ficus benjamina Linn., which may be corrct. J?lanco's specimens were from Cebu. V., Talicot.

Ficus hispida odorata Blanco, ed. 1, 686; ed. 2, 476= Ficus odorata (Blanco) Merrill, Govt. Lab. Publ. 17: 15. 1904. Erroneonsly reduced by Villar to Ficus pungens Reinw. T., Agosos.

Ficus aspera Forst., Blanco, ed. 1, 676; ed. 2, 476. Blanco gives only a partial translation of the description of this species, without definitely referring any form to the species. Villar erroneously reduces it to Ficus hirta Vahl.

Ficus hispida linearis Blanco, ed. 1, 685; ed. 2, 476=Ficus cumingii Miq.!. Erroneously reduced by Villar to Ficus heterophylla Linn. T., V., P., Isis, Asis, Issio, Isioisio.

Ficus hispida hastata Blanco, ed. 1, 685; ed. 2, 476= Ficus quercifolia Roxb.!

Ficus heterophylla Blanco, ed. 1, 685; ed. 2, 476, non Linn. = Ficus quercifolia Roxb.! T., Asis, Isis.

* Ficus argentea Blanco, ed. 1, 681; ed. 2, 473. Reduced by Villar to Ficus polycarpa Wall., which is a synonym of Ficus ribes Reinw., and which is certainly an error.! Blanco's specimens were from the seashore at Mariveles, Province of Bataan.

* Ficus rostrata Blanco, ed. 1, 679; ed. 2, 472. Reduced by Villar to Ficus radicans Roxb., which is a synonym of Ficus rostrata Lam. Possibly correctly referred.

* Ficus aspera volubilis Blanco, ed. 1, 676; ed. 2, 472. Erroneously reduced, by Villar to Ficus hederacea Roxb., which is probably a synonym of Ficus scandens Roxb. Blanco's specimens were from Calapan, Mindoro, a small vine with very rough leaves. T., Hagupit.

Ficus aspera nota Blanco, ed. 1, 677; Ficus scabra Blanco ed. 2, 471, non Forst. = Ficus nota (Blanco) Merrill, Govt. Lab. Publ. 17: 10. 1904.! Erroneously reduced by Villar to Ficus racemifera Roxb. T., Tibig.

Ficus glomerata Blanco, ed. 1, 683; ed. 2, 475, non Roxb. = Ficus minahassa Miq.! Erroneously considered by Villar to be identical with Roxburgh's species. T., Tibig na lalaqui. V., Haguimit, Aimit.

Ficus laevigata Blanco, ed. 1, 682; ed. 2, $474=$ Ficus variegata Blume.! Erroneously reduced by Villar to Ficus cuneata Miq. T., Tangisang bayauac.

Ficus hauili Blanco, ed. 1, 684; Ficus laurifolia Blanco, ed. 2, 475. Apparently a distinct species. Reduced by Villar to Ficus leucopleura Blume, which is a synonym of Ficus leucantatoma Miq. A shrub or small tree. T., Hauili. 
* Ficus laccifera Blanco, ed. 1, 673; ed. 2, 468, non Roxb. Reduced by Villar to licus radiata Decne., which is also a synonym of Ficus leucantatoma Poir. Villar's reduction is probably an error. Blanco's specimens were from Cebu and Negros, said to be a very common shrub. V., Lagnob.

Ficus pseudopalma Blanco, ed. 1, 680; el. 2, 473. A distinct species.! This species is not listed in Index Kewensis. 'T., Niogniogan.

Morus tinctoria Blanco, ed. 1, 404, non Linn.; Broussonetia tinctoria Blanco, ed. 2, 488, non Spreng. = Cudrania obovata Trec.! T., Tahid labuyo. I., T'alolong.

Artocarpus incisa Jinn. f., Blanco, ed. 1, 668; ed. 2, 465.! The earliest name for this species is Artocarpus communis Forst. T., V., P., Antipolo, Tipolo.

Artocarpus rima Blanco, ed. 1, 671; ed. 2, 467. Reduced by Villar to Artocarpus incisa Linn. f., var. lacvis Miq. From Blanco's description certainly not this variety. A form or variety of the preceding species.! T., Rima. V., Colo. C., Ogob. ?

Artocarpus camansi Blanco, ed. 1, 670; ed. 2, 467. A form or variety of Artocarpus incisa Linn. f.! T., I., Dalangain, Dolongain, Camongsi. I., Pacac.

Artocarpus odoratissima Blanco, ed. 1, 671; ed. 2, 467. Certainly closely related to Artocarpus incisa Linn. f., and probably only a variety of that species. T., Loloi.

Artocarpus maxima Blanco, ed. 1, 669; Artocarpus integrifolia Linn. f., Blanco, ed. 2, 466. The latter name is correct. T., Nangca.

Artocarpus ovata Blanco, ed. 1, 666; el. 2, 464, non Noronha $=$ Artocarpus cumingiana Trec.! T., Anobing, Anobling. P., Anobion.

Artocarpus lamellosa Blanco, ed. 1, 667; ed. 2, 465. Reduced by Villar to Artocarpus nitida 'Trec., but Blanco's name is the older and should be retained. 'T., Anobing caguiosing, Anobling.

Procris violacea Blanco, ed. 1,706 ; ed. 2, $490=$ Conocephalus violaceus (Blanco) (Conocephalus ovatus Trec.!). Erroneously reduced by Villar to the related Malayan species, Conosphalus suaveolens Blume. T., Lagna.

* Procris erecta Blanco, ed. 1, 707; ed. 2, 490. Reduced by Villar to conocephalus, as a distinct species, C.erectus (Blanco) F.-Vill. Known only from Blanco's description. T., Hanopol.

Urtica sessiliflora Blanco, ed. 1, 696 , non Swartz; Urtica capitata ? I3lanco, ed. 2, 483, non L. = Fleurya interrupta Gaud.! T., Lipang C'astila. V., Langala, Damoro, Dalamo, Daodaua. P., Lopa.

Urtica umbellata Blanco, ed. 1, 696, non Bory; Urtica ferox Blanco, ed. 2, 484, non Forst. = Laportea gaudichaudiana Weda.! 'T., V., Lipa, Lipai, Lingaton, A pariagua. P., Lipang doton.

* Dorstenia pubescens Blanco, ed. 1, 692; ed. 2, 481, non Forst. Reduced by Villar to Llatostema obtusum Wedl., which is probably an error. Certainly, however, a species of Elatostema. 
Urtica nivea Linn., Blanco, ed. 1, 69ī; ed. 2, 484=Boehmeria nivea (Linn.) Hook. et Arn.! I., Ig., Amarai, Arimai, Labnis.

Urtica villosa Blanco, ed. 1, 695; ed. 2, 483, non Salzm. Reduced by Villar to Pouzolzia indica Gaud., which is probably correct.

* Urtica japonica Blanco, ed. 1, 684; ed. 2, 482, non Linn. Reduced by Villar to Pouzolzia viminea Wedd., which is probably an error. Probably, however, a species of Pouzolzia.

Urtica baccifera Blanco, ed. 1, 695, non Linn.; Urtica arborescens Blanco, ed. 2, 483, non Poir. = Pipturus asper Wedd.! T., Dalonot. V., Dalonotan, Handaramai, Hindalamai. P., Dalonot.

\section{JUGLANDACEA.}

Gyrocarpus pendulos Blanco, ed. 2, $55=$ Engelhardtia spicata Blume.! T., Pingol.

\section{CASUARINACEAE.}

Casuarina equisetifolia Forst., Blanco, ed. 1, 661; ed. 2, 460. Certainly this species, although Villar refers it to Casuarina sumatrana Jungh. T., Agoho. V., Agoho, Malabohoc. P., Agoho. I., Aro, Caro, Agoo.

\section{CUPULIFEREAE.}

Quercus molucca Blanco, ed. 1, 726, non Rumph.; Quercus concentrica Blanco, ed. 2, 502, non Lour. = Quercus llanosii A. DC.! T., Alayan, Hayopag.

Quercus glabra Blanco, ed. 1, 727, non Thunb. Quercus ovalis Blanco, ed. 2, 502. A distinct species; the second name should be retained. Quercus blancoi A. DC., is a synonym. T., Macabingao, Mangasiriqui, Hayopag.

* Quercus cooperta Blanco, ed. 2, 503. Reduced by Villar to Castanopsis costata A. DC., probably, however, some species of Quercus. Blanco's specimens were from Angat.

* Quercus cerris Blanco, ed. 1, 727; ed. 2, 503. Reduced by Villar to Castanopsis javanica A. DC., probably, however, some species of Quercus. Blanco's specimens were from Angat.

Fagus philippinensis Blanco, ed. 2, 503 = Castanopsis philippinensis (Blanco) Vidal.! Erroneously referred by Villar to Castanopsis sumatrana A. DC. T., Tacatac, Talacatac, Lovian.

\section{SALICACEA.}

Salix azaolana Blanco, ed. 2, 539. Reduced by Villar to Salix tetrasperma Roxb., but apparently a distinct species, represented by Nos. 1987 and 2139 Forestry Bureau, Ahern's collector. T., Tiaun.

$21896-6$ 


\section{(XNETACEAE.}

Gnetum gnemon Linn., Blanco, ed. 1, 747 ; ed. 2, 514.! T., Culiat.

Thoa pendula Blanco, ed. 1, 746; Thoa edulis Blanco, ed. 2, 514. Reduced by Villar to Gnetum scandens Roxb., but probably the same as Gnetum latifolium Blume. T., Culiat, Lamparahan, Biasbias, Taval, Malaitmo, Bangal, Itmong ouac.

\section{CONIFEREA.}

Agathis loranthifolia Blanco, ed. 2, 528, non Salisb. = Agathis philippinensis Warb.!

Pinus taeda Blanco, ed. 1, 767; ed. 2, 528, non Linn. = Pinus insularis Endl.! I., Saleng.

\section{CYCADACEA.}

Cycas circinalis Linn., Blanco, ed. 1, 745; ed. 2, 513.! T., Patúbo, Pitogo, Bitógo.

\section{HYDROCHARIDEA.}

Ottellia alismoides Pers., Blanco, ed. 1, 461 ; ed. 2, 321.! 'T., Culaboa.

Ottellia ensiformis Blanco, ed. 1, 460; ed. 2, 320. Retained by Naves as a distinct species, citing Damasonium lancifolium Presl., as a synonym. Certainly a form of the preceding species.! Blanco's specimens were from Pasig, Province of Rizal, flowering in March. T., Espada.

Vallisneria spaerocarpa Blanco, ed. 1, 780; ed. 2, $538=$ Enhalus lioenigii Rich.! T., Isai.

Vallisneria spiralis Linn., Blanco, ed. 1, 781; ed. 2, 538.! T., Cintascintasan.

\section{SCITIMINEAE.}

Musa. Blanco describes eighteen varieties of the Banana, which, with the exception of four, are being placed by him under the species Musa paradisiaca Linn. He states that he saw in the Philippines fiftyscven varieties, and divides the various forms and species into two groups, those with thick-skinned fruit, and those with thin-skinned fruit. The many varieties described by Blanco are mostly entirely ignored by Schumann ${ }^{1}$ in his recent monograph of the family, although many of them are very characteristic. It is quite impossible with our present information to correlate Blanco's varieties with those of other authors from the Malayan region, and accordingly the following list is copied from the two editions of this Flora, without reference to the identifications of Naves. The common native name for Bananas is Saguing, the Spanish names Platanos and Plantaios being also frequently used.

Musa paradisiaca Linn., Blanco, ed. 1, 239; ed. 2, 168.

${ }^{1}$ Engler, Pflanzenreich 4, 1900. 
BANANAS WITH THICK-SKINNED FRUITS.

* M. paradisiaca compressa Blanco, ed. 1, 240; ed. 2, 168. T., Bisco, Saba. Sp.-Fil., Obispo.

* M. paradisiaca ternatensis Blanco, ed. 1, 243; ed. 2, 170. T., T'ernate, Gloria.

* M. paradisiaca lacatan Blanco, ed. 1, 243; ed. 2, 170. T., Lacatan.

* M. paradisiaca pumila Blanco, ed. 1, 244; ed. 2, 171. T., Tampohin.

* M. paradisiaca suaveolens Blanco, ed. 1, 244; ed. 2, 171. T., Bungulan.

* M. paradisiaca magna Blanco, ed. 1, 244; ed. 2, 171. T., Tondoc.

* M. paradisiaca subrubea Blanco, ed. 1, 245; ed. 2, 171.

* M. paradisiaca violacea Blanco, ed. 1, 245; ed. 2, 171.

* M. paradisiaca glaberrima Blanco, ed. 1, 245; ed. 2, 171. T., Galamai señora, Dinugoan.

* M. paradisiaca maxima Blanco, ed. 1, 245; ed. 2, 171. T., Batavia, Matavia, Songai, Anuang.

* M. paradisiaca longa Blanco, ed. 1, 245; ed. 2, 171. T., Quinauayan.

* M. paradisiaca tombac Blanco, ed. 1, 246 ; ed. 2, 171. 'T., Tinumbaga, Goyoran.

* M. paradisiaca ulnaris Blanco, ed. 1, 246; ed. 2, 172. This variety should be entirely discarded, as Blanco described it entirely from hearsay, and never saw specimens. "Los que han visto y comida el fruto, dicen que es del grueso de la pantorrilla, y que llega á tener hasta una braza de largo.!"

M. troglodytarum Linn., Blanco, ed. 1, 246; ed. 2, 172= Musa paradisiaca Linn., subsp. troglodytarum (Linn.) Baker. T., Botohan, Botoan.

M. trogloditarum errans Blanco, ed. 1, 247; ed. 2, 172. Certainly a form or variety of Musa textilis Neé.! T., Saguing machin, Saguing na ligao.

* M. troglodytarum dolioliformis Blanco, ed. 1, 855; ed. 2, 174.

M. trogloditarum textoria Blanco, ed. 1, 247; ed. 2, $173=$ Musa textilis Neé.! T., Abacá.

\section{BANANAS WITH THIN-SKINNED FRUITS.}

* M. paradisiaca glauca Blanco, ed. 1, 250; ed. 2, 175. T., Bingticohol, T'inalong.

* M. paradisiaca cinerea Blanco, ed. 1, 250; ed. 2, 175. Said by Blanco to have been introduced from India. T., Letondal.

Amomum zingiber Linn., Blanco, ed. 1, 2; ed. 2, $2=$ Zingiber officinale Rosc.! T., Luya. C., Laya.

Amomum zerumbet Linn., Blanco, ed. 1, 2; ed. 2, 2=Zingiber zerumbet (Linn.) Rosc.! T., Luyang osiu, Lampuyan.?

Curcuma longa Linn., Blanco, ed. 1, 5 ; ed. 2, 4.! T., Dilao. V., Dulao, Calavaga, Quinamboy. P., Angai. 
* Costus luteus Blanco, ed. 1, 4; ed. 2, 3=Curcuma xanthorrhiza Roxb. (?) T., Tamahilan, Tamohilan, Tamo, Tamocansi, Tumahila, Bolon. P., Tamo.

* Costus nigricans Blanco, ed. 1, 3; ed. 2, 3. Reduced by Naves to Curcuma zerumbet Roxb., which is a synonym for Curcuma zedoaria Rosc. The latter name is probably the correct one for Blanco's species. T., Barac, Lampuyang.

Kaempferia rotunda Blanco, ed. 1, 5; ed. 2, 4, non Linn. Reduced by Naves to Kaempferia galanga Linn., var. Probably a form of this species. T., Dusog, Duso, Dusod, Guisol. P., Cusol, Guisol, Dusol.

* Amomum echinatum Willd., Blanco, ed. 2, 3. Reduced by Naves to Amomum aculeatum Roxb., var. majus. This may be correct. Blanco's specimens were from Angat, Province of Bulacan.

Renealmia gracilis Blanco, ed. 1, I; Renealmia exaltata Blanco, ed. 2, 1, non Linn. = Alpinia elegans (Presl) K. Sch. (Kolowratia elegans Presl; Alpinia gracilis Rolfe). Erroneously reduced by Naves to Alpinia gigantea Blume. T., Tagbac. P., V., Catcatan, Catotang, Tagbac, Salbac, Bagombon.

Maranta arundinacea Blanco, ed. 1, 7; ed. 2, 5, non Linn. = Donax arundastrum Lour.! T., Tagbactagbac, Bamban.

Canna indica Linn., Blanco, ed. 1, 6; ed. 2, 5.! T., Cacuentasan, Tiquis tiquis, Ticas, Ticas ticas.

\section{ORCHIDACEA.}

* Epidendrum equitans Blanco, ed. 1, 645; ed. 2, 449. Reduced by Naves to Eria aporoides Lindl., but the identification is very doubtful. Said by Blanco to be common in the Tala Mountains, Province of Rizal or Bulacan.

* Epidendrum lineare Blanco, ed. 1, 644; ed. 2, 449, non Linn. Reduced by Naves to Cleisostoma ionosmum Lindl., which may possibly be correct.

* Orchis lanigera Blanco, ed. 1, 641; ed. 2, 446. Reduced by Villar to Aerides virens Lindl, which is probably an error. Flowering in July.

Arethusa glutinosa Blanco, ed. 1, 641; ed. 2, 446. Reduced by Naves to Geodorum semicristatum Lindl., which is probably correct. T., Cebollas del monte, Fariqtan, Camaog.

* Cypripedium bulbosum Blanco, ed. 1, 637; ed. 2, 444, non Linn. Reduced by Naves to Eulophia sumatrana Blume, which is probably an error. A small plant, flowering in July.

* Dendrobium teretifolium Spreng. ? Blanco, ed. 2, 444; D. teres Blanco, ed. 1. 638. Naves considers that Blanco correctly interprets Sprengel's species, and reduces it to Luisa teretifolia Gaud. Blanco's specimens were from Angat, Province of Bulacan, flowering in January or March.

Phalaenopsis amabilis Blume, Blanco, ed. 2, 592. Probably correctly determined by Blanco. T., Dapo. 
* Ophrys cernua Blanco, ed. 1, 639; ed. 2, 445. Reduced by Nares to Grammatophyllum scriptum Blume, which is probably an error. A terrestrial plant, growing near the sea, at Bauang, Province of Batangas, flowering in March.

* Vanilla ovalis Blanco, ed. 2, 448; Epidendrum vanilla Blanco, ed. 1, 643 , non L. Naves considers that Blanco's species is identical with Vanilla aromatica Sw., but this is probably an error. Blanco's specimens were from Majayjay, Province of Laguna.

* Vanilla majaijensis Blanco, ed. 2, 593. Reduced by Naves to Vanilla planifolia Ait., which is probably an error. Probably the same as the species described by Blanco as Vanilla ovalis, whatever that may be. Blanco's specimens were from the same locality as the preceding species.

* Thelymitra malintana Blanco, ed. 1, 462; ed. 2, 447. Reduced by Naves to Habenaria trinervis Wight., which is probably an error, at least as to the species. Said by Blanco to be very common in Malinta, near Manila, flowering in October.

\section{IRIDACEAE.}

Antholyza meriana Blanco, ed. 1, 24; ed. 2, 18, non Linn. Reduced by Naves to Sisyrinchium palmifolium Linn., an American species, which may be correct. Blanco's specimens were from cultivated plants flowering in November. Sp.-Fil., Cebollas de Persia.

\section{AMARYLLIDACE $\mathbb{E}$.}

Gethyllis acaulis Blanco, ed. 1, 260; ed. 2, 181. Reduced by Naves to Hypoxis franquevillei Miq. = Hypoxis fava Lour., which is certainly correct. Blanco's specimens were from Malinta, near Manila, flowering in October.

Agave americana Blanco, ed. 1, 258; ed. 2, 180=Agave rigida Mill. var.! T., Magui.

Polianthes tuberosa Linn., Blanco, ed. 1, 259; ed. 2, 181. Correctly identified by Blanco, a Mexican species introduced and cultivated, flowering in May. Sp.-Fil., Azucena.

Crinum giganteum Blanco, ed. 2, 175, non Andr.; Haemanthus pubescens Blanco, ed. 1, 253. Reduced by Naves to Crinum asiaticum Linn., which may be correct. T., Bacong.

Crinum asiaticum Blanco, ed. 1, 251; ed. 2, 175, non Linn. Reduced by Naves to Crinum gracile E. Meyer, which is probably correct. Blanco's specimens were from Mandaloyon, near Manila, flowering in July.

* Amaryllis atamasco Blanco ed. 1, 254; ed. 2, 178, non Linn. Reduced by Naves to Hippeastrum miniatum Herb., an American species, which may be correct, although Blanco does not state whether or not the plant was cultivated. Flowering in February. T., Bacong, Talicoran. 
Pancratium amboinense Linn., ? Blanco, ed. 1, 252; ed. 2, 177. Reduced by Naves to Eurycles amboinensis Herb. = Eurycles sylvestris Salisb., which may be correct. ('ommon along the seashore, flowering in April. T., Catongal. V., Abur, Panabor, Catangal, Talaonor, Tonuar, Dausum.

* Pancratium maritimum Blanco, ed. 1, 252; ed. 2, 177, non Linn.? The genus is probably correct, but the species is very doubtful. Pancratium maritimum Linn., is an American species. Blanco's specimens were from the Province of Batangas, there called Cebollas del Monte, from which it is evident that the plant that Blanco describes was probably from the forests, and not from the seashore.

Pancratium zeylanicum Linn., Blanco, ed. 1, 253; ed. 2, 177. Probably correctly identified by Blanco. Flowering in April. T., Lunas, Catongal. Sp.-Fil., Rosas de Persia.

* Pancratium illyricum Blanco, ed. 1, 251; ed. 2, 176, non Linn. Reduced by Naves to Hymenocallis adnata Herb., an American species which may be correct, although Blanco does not state whether or not his material was from cultivated specimens. Flowering in June. T., Tagalhi.

\section{BROMELIACEA.}

Bromelia ananas Linn., Blanco, ed. 1, 230; ed. 2, $162=$ Ananassa sativa Lindl.! Sp.-Fil., Piña.

\section{TACCACEAE.}

Tacca pinnatifida Forst., Blanco, ed. 2, 182; Tacca gaogao Blanco, ed. 1, 262, 856. The first name is correct. Z., Tambobon. I., Panarien. T., Gaogao.

Tacca vesicaria ? Blanco, ed. 1, 261; T. palmata Blanco, ed. 2, 182. Considered by Naves to be identical with Tacca palmata Blume. Blanco's specimens were from Malinta, near Manila, flowering in July. V., Magsaloro. Sp.-Fil., Corazon de Angel.

\section{DIOSCOREACEAE.}

* Dioscorea divaricata Blanco, ed. 1, 797; ed. 2, 550. Reduced by Naves to Dioscorea batatas Decne., but even if correctly referred, Blanco's name is the older. A species flowering in October, the tubers very deep in the ground. T., Paquit, Cobag. V., Baliacag. I., Dulian.

Dioscorea alata Linn., Blanco, ed. 1, 799; ed. 2, 550.! T., Ubi. V., Quinampai.

Dioscorea pentaphylla Linn., Blanco, ed. 1, 802; ed. 2, 552.! T., Limalima.

Dioscorea papillaris Blanco, ed. 1, 801; ed. 2, 552. Reduced by Naves to Dioscorea sativa Linn., which is probably correct. T., Tongo. Quiroi.

Dioscorea triphylla Blanco, ed. 1, 799; ed. 2, 551, non Linn = Dioscorea daemona Blume!! Reduced by Naves to Dioscorea hirsuta Blume. T., Nami. V., Corot, Gayos. P., Calut. 
Dioscorea tugui Blanco, ed. 1, 800; Dioscorea sativa Blanco, ed. 2, 551 , non Linn. $=$ Dioscorea fasciculata Roxb.! 'T., Toqui.

\section{LILIACEIE.}

Smilax pseudochina Blanco, ed. 1, 795; ed. 2, 548, non Linn. = Smilax bracteata Presl, for most part, although Naves considers that Blanco's description also applies in part to Smilax china, S. laevis and Heterosmilax bornensis A. DC. T., Obat, II ampas tagbalang, Camagsa obat. V., Banag, Ubiubihan, Ronas. P., Barag. Sp.-Fil., Zarzaparrilla.

* Smilax fistulosa Blanco, ed. 1, 796; ed. 2, 549. Reduced by Naves to Smilax indica Vitm., which may be correct. Blanco's description is very imperfect.

Smilax latifolia Blanco, ed. 2, 548. Reduced by Naves to Smilax macrophylla Roxb., which may be correct. T., Sipit olang. V., Ronas.

* Smilax divaricata Blanco, ed. 1, 795; ed. 2, 548. Reduced by Naves to Dioscorea myriantha Kunth. From Blanco's description the species may be either a Smilax or a Dioscorea, but from the native names it is apparently a species of Smilax. T., Obat, Camagsa obat, Hampas tagbalang or tigbalang.

Flagellaria indica Linn., Blanco, ed. 2, 196.! T., Balinguai.

Dracaena terminalis Linn., Dlanco, ed. 1, 263; ed. 2, $183=$ Cordyline terminalis (Linn.) Kunth.! T., Varas hari, Varas ni Jesé, Toncod obispo.

Aloe humilis Blanco, ed. 1, 256; ed. 2, 179, non ? Linn. Reduced by Villar to Aloe barbadensis Mill. A cultivated species. T., Sabila. V., Dilang boaya.

Allium tricoccum Blanco, ed. 1, 239; ed. 2, 167, non Ait. Reduced by Villar to Allium uliginosum Don., which is cited by Hooker as a synonym of Allium tuberosum Roxb. T., Cuchai. V., Ganda.

\section{PON'TEDERIACEA.}

Pontederia vaginalis Blanco, ed. 1, 255; ed. 2, 178, non Linn. = Monochoria hastaefolia Presl.! T., Calaboa.

\section{COMMELINACEAE.}

Lechea minor Blanco, ed. 1, 52; ed. 2, 35, non Linn. = Pollia sorzogonensis Presl.! V., Lohod lohod.

Commelyna polygama Blanco, ed. 1, 25; ed. 2, 18, non Roth. = Commelina benghalensis Linn.! T., Alicbangon. V., Sabilao. P., Biasbias.

Commelyna cristata Linn., Blanco, ed. 1, 231; ed. 2, $163=$ Cyanotis cristata (Linn.) R. et S.!

Tradescantia geniculata Blanco, ed. 1, 232, non Jacq. = Floscopa scandens Lour.! This species is excluded from the second edition:

Tradescantia discolor Smith, Blanco, ed. 1, 232; ed. 2, $163=$ Rhaeo discolor Hance.! 


\section{PALME.}

Calamus usitatus 13lanco, ed. 1, 265; ed. 2, 185 = Dacmonorops gaudi chaudii Mart.! Erroneously reduced by Naves in part to Daemonorops rumphii Mart., and in part to Calamus pisicarpus Blume, species that do not extend to the Philippines. T., Iantoc, Oayi.

Calamus gracilis Blanco, ed. 1, 267; ed. 2, 186, non Roxb. = Calamus blancoi Kunth.! Erroneously reduced by Naves to Calamus buroensis Mart., a species that does not extend to the Philippines. T., T'alola.

Calamus mollis Blanco, ed. 1, 664; ed. 2, 184. A good species; Calamus haenkeanus Mart., is a synonym. T., Dit-an.

Calamus maximus Blanco, ed. 1, 266; ed. 2, 185. This is a distinct species (No. 1893 Merrill). It certainly is not a synonym of Calamus albus Pers., to which Naves reduces it, as the latter species is not found in the Philippines. T., Palasan. P., Labni. V., Parasan, Calapi. C., Labnit, Calapi.

Areca catechu Linn., Blanco, ed. 1, 714; ed. 2, 494.! T., V., Bonga. P., Luyos.

Areca catechu humilis Blanco, 11. cc., may be a valid variety. It is reduced by Naves to Areca catechu Linn., var. pumila Miq. T., Mangipod, Sacsic.

Caryota urens Blanco, ed. 1, 740 ; ed. 2, 510, non Linn. = Caryota cumingii Lodd.! T., Taquipan, Taguipan.

Caryota palindan Blanco, ed. 2, 513= Orania PALINdaN (Blanco) (Orania philippinensis Scheff.). Erroneously reduced by Nares to Orania regalis Zipp. T., Palindan, Barangoi.

Caryota tremula Blanco, ed. 1, 744; ed. 2, 512. Reduced by Naves to Wallichia tremula, which may be correct. 'T., Dumayaca.

Caryota onusta Blanco, ed. 1, 741; ed. 2, 511 = Arenga saccharifera Lab.! T., Cauon, Iroc, Pugahan.

Corypha umbraculifera Linn., Blanco, ed. 1, 228; ed. 2, 160.! T., B., Buri, Buli.

Corypha minor Blanco, ed. 1, 229; ed. 2, 161, non Jacq. = Livistona merrillii Beccari.! Erroneously reduced by Naves in part to Livistona rotundifolia Mart., and in part to L. papuana Beccari, neither species being known from the Philippines. V., 'T., Anahao. P., Anao, Bolong ulong.

Cocos nucifera Linn., Blanco, ed. 1, 716; ed. 2, 495. T., I., C., Niog. P., Ngongot.

Cocos mammilaris Blanco, ed. 1, 722; ed. 2, 499. A form or variety of the preceding species reduced by Naves to the var. lansiformis Miq. T., Adiavan.

Nipa littoralis Blanco, ed. 1, 662; Nipa fructicans Wurmb., Blanco, ed. 2, 461. The second name is correct. T., Nipa, Sasa. 


\section{PANDANACEIS.}

Pandanus spiralis Blanco, ed. 1, 777 ; ed. 2, $535=$ Pandanus tectorius Soland.! 'T., Pandan.

Pandanus gracilis Blanco, ed. 1, 77s; ed. 2, 536. Erroneously reduced by Naves to Pandanus humilis Rumph., a species that does not extend to the Philippines. A species closely related to, if not identical with Pandanus whitfordii Merrill, although Blanco describes his species as unbranched. Blanco's specimens were from the Tala Mountains, Province of Rizal or Bulacan, flowering in May.

Pandanus malatensis Blanco, ed. 2, 536. Reduced by Naves to Pandanus littoralis Jungh. Certainly a form or variety of Pandanus tectorius Soland.! Blanco's specirens were from Malate, a suburb of Manila, flowering in November.

* Pandanus exaltatus Blanco, ed. 1, 778; ed. 2, 536. Erroneously reduced by Villar to Pandanus fascicularis Lam. Blanco evidently includes two species in his description, one form growing in the mountains, the other on the seashore. The latter is certainly Pandanus tectorius Soland., what the former is can not be determined from Blanco's description. T., Alas-as. In the Tala Mountains, Carahumai.

* Pandanus sabotan Blanco, ed. 1, 779; ed. 2, 537. Erroneously reduced by Naves to Pandanus dubius Spreng. Certainly a distinct species, but knowil only from Blanco's description. Blanco's specimens were from the Province of Laguna. T., Sabotan.

Pandanus radicans Blanco, ed. 1, 780; ed. 2, 537. Reduced by Naves to Pandanus bagea Miq., which is a synonym of Pandanus dubius Spreng., and which is probably correct. Pandanus dubius has recently been discovered in the southern Philippines. Blanco's specimens were from Leyte. V., Olango.

* Pandanus inermis Blanco, ed. 2, 537, non Roxb. Erroneously reduced by Naves to Pandanus moschatus Rumph. Probably a good species, but Blanco describes the leaves only. A species from the mountains near Angat, Province of Bulacan, the leaves without spines.

* Tillandsia pseudo-ananas Blanco, ed. 1, 853; ed. 2, 162. Reduced by Naves to Freycinetia insignis Blume, a species that does not extend to the Plilippines. Probably a species of this genus, but it is impossible to determine which from Blanco's description. Blanco's srecimens were from Angat, Province of Bulacan, tlowering in August.

\section{ARACEAE.}

* Batis hermaphrodita Blanco, ed. 1, 791; ed. 2, 544. Reduced by Naves to Pothos chapelieri Schott., which is certainly an error, as that species is known only from Madagascar. The specimen of Vidal's collection, cited by Naves, is Pothos scandens Linn. Blanco's specimens were from Bauang, Province of Batangas, a scandent plant, flowering in December. T., Apis. 
Pothos pinnata Blanco, ed. 1, 646; ed. 2, 450, non Linn. Reduced by Naves to Epipremnum medium Engl., which is probably correct. Flowering in February. T., Tibatib, Tampin banal, Malapacpac balavay. V., Bisaco, Tirbatib, Dibatib, Balicupcup, Daila, Garban, Tacolin, Horog. I., Amolong.

Arum decurrens Blanco, ed. 1, 656; ed. 2, $457=$ Amorphophallus campanulatus Blume.! T., Apon, Pongapon. I., Carot, Corot.

Calla gaby Blanco, ed. 1, 659; Caladium esculentum Blanco, ed. 2, $459=$ Colocasia antiquorum Schott.! var. T., V., P., Gaby, Gávay, Lagvay, Dagmay, Gandus.

Calla badian Blanco, ed. 1, 658. Reduced by Villar to Alocasia indica Schott. var. variegata Engl., which is certainly an error. Blanco's species is certainly a form of the preceding species.! Included in the second edition only in a note following Caladium esculentum. T., V., Galiang, Biga, Badiang.

Calla maxima Blanco, ed. 1, 658; Arum grandifolium Blanco, ed. 2, $458=$ Alocasia indica Schott.! T., V., P., Biga.

Arisaema polyphylla Blanco, ed. 1, 659; Caladium ? digitatum Blanco, ed. $2,459=$ ARISAEMA POLYPHYLla (Blanco) (Arisaema cumingii Schott.!). Blanco's specimens were from Agoo, Province of Union.

Arum divaricatum Linn., Blanco, ed. 1, 657; ed. 2, 458. Reduced by Naves to Typhonum divaricatum Decaisne, which is probably correct. T., Gabigabihan, Gabingouac.

Pistia stratiotes Linn., Blanco, ed. 1, 651; ed. 2, 454.! 'T., Quiapo. I., Loloan.

\section{LEMNACEAE.}

Lemna gibba Blanco, ed. 1, 672; ed. 2, 468, non Linn. Reduced by Naves to Lemna oligorrhiza Kurz, which may be correct. T., Inalai.

\section{TYPHACEA.}

Typha angustifolia Linn., Blanco, ed. 1, 687; ed. 2, 477 = Typha angusti . folia Linn., subsp. javanica.! T., Balangot.

\section{NAIADACEAE.}

* Najas palustris Blanco, ed. 1, 660; Najas lobata Blanco, ed. 2, 459. Reduced by Naves to Naias tenuifolia R. Br., which is probably an error. Probably the same as Naias minor All. A plant growing in stagnant fresh water, flowering in March.

\section{CYPERACEA:}

Kyllinga triceps Blanco, ed. 1, 34; ed. 2, 23, non Vahl. = Kyllinga monocephala Rottb.! 'T., Muthang, Anuang.

* Cyperus difformis Blanco, ed. 1, 32; ed. 2, 22, non Linn. Reduced by Naves to Cyperus ornatus R. Br., which is a synonym of Cyperus procerus Rottb., probably an error. 'T., Titio, Tiquio. 
Cyperus rotundus Linn., Blanco, ed. 1, 31; ed. 2, 21.! 'T. II utha. V., Botobotones. P., Mota, Malaapolid, Sursur, Onoran, Casung, Omadiung, Galonalpas.

* Carex tuberosa Blanco, ed. 1, 35; ed. $\triangle, 24$. Reduced by Naves to Eleocharis tuberosa Schult., which is probably an error, at least as to the species. Blanco's specimens were from Hagonoy, Province of Bulacan, the tubers edible. 'T., Potoc, Cibicibollasan, A pulid. Sp.-Fil., Cabezas de Negrito.

Carex glomerata Blanco, ed. 2, 24, non 'Thunb. Reduced by Villar to Fimbristylis ferruginea Vahl., which may be correct. Blanco's specimens were from Mandaloyon, near Manila, flowering in January. T., Apulid.

Scirpus niloticus Blanco, èd. 1, 33; ed. 2, 23, non Gmel. = Fimbristylis miliacea Vahl.!. 'T., Agor.

\section{GRAMINEAE.}

* Paspalum villosum Blanco, ed. 1, 40; ed. 2, 28, non Thunb. Reduced by Villar to Paspalum mollicomum Kunth, which is a synonym of Panicum muticum Forsk. Blanco's description hardly applies to the latter species, which, moreover, is not definitely known from the Philippines. T., Parag-is.

Panicum miliaceum Blanco, ed. 1, 39; ed. 2, 28, non Linn. = Chaetochloa italica (Linn.) Scribn.! (Setaria italica Kunth.) T., Dava. I., Bucacao.

Cenchrus hexaflorus Blanco, ed. 1, 36; ed. 2, $24=$ Pennisetum macrostachyum Brongn.! Reduced by Villar to Pennisetum nigricans Miq., which is a synonym of Pennisetum compressum R. Br. Blanco's specimens were from the Province of Batangas, flowering in June. T., Aguingai.

Stipa spinifex Linn., Blanco, ed. 1, 46; ed. 2, $31=$ Spinifex squarrosus Linn.!

Spinifex squarrosus Linn., Blanco, ed. 1, 46; ed. 2, 31.!

Egilops fluviatilis Blanco, ed. 1, 47; ed. 2, 32. Reduced by Villar to Rottboellia muricata Retz., which equals Eremochloa muricata (Retz.) Hack. Blanco's species probably is the same as Manisuris exaltata (Linn. f.) O. Ktze. T., Timsim.

Zea mays Linn., Blanco, ed. 1, 686; ed. 2, 476.! Sp.-Fil., Maiz.

Coix lachryma Linn., Blanco, ed. 1, 688; ed. 2, $478=$ Coix lachryma-jobi Linn.! T., Tigbi.

Andropogon contortus Linn., Blanco, ed. 1, 38; ed. 2, $26=$ Heteropogon contortus (Linn.) R. et S.!

* Andropogon ramosus Blanco, ed. 1, 37; ed. 2, 25, non Forsk. Reduced by Villar to Ischaemum ciliare Retz., which is certainly an error, at least as to the species. A species growing in the rice paddies in November, in appearance somewhat resembling wheat. T., Tinitrigo Sp.-Fil., Trigo. 
* Andropogon schoenanthus Blanco, ed. 1, 39; ed. 2, 27, non Linn. Considered by Villar to have been correctly identified by Blanco, but it is very doubtful if Blanco describes the Linnean species. T., Salai, Tanglad, Paja de meca. V., Baliyoco.

Andropogon nardus Blanco, ed. 1, 39; ed. 2, 27, non Linn = Andropogon squarrosus Linn.! Andropogon muricatus Retz., to which Villar reduces Blanco's species as a synonym of Andropogon squarrosus Linn. Sp.-Fil., Raiz de mora, Yerva mora.

Saccharum koenigii Blanco, ed. 1, 44; ed. 2, 30, non Retz. = Saccharum spontaneum Linn.! Erroneously reduced by Villar to Imperata arundinacea Cyr. 'T., V., Cogon. P., Ilib, Bálili. C., Cogon cogon.

Rhaphis trivialis Lour., Blanco, ed. 1, 45; Andropogon aciculatus Retz., Blanco, ed. 2, $26=$ Chrysopogon aciculatus (Retz.) Trin.! T., Amores secos, Marisicos, Mariscos.

Holcus saccharatus Linn., Blanco, ed. 1, 47; ed. 2, $32=$ Sorghum saccharatum (Linn.) Pers. var.! 'T., Batad.

Saccharum officinarum Linn., Blanco, ed. 1, 42; ed. 2, 29.! T., Tubo. Sp.-Fil., Caña dulce.

Anthistiria gigantea Cav., Blanco, ed. 1, 49; ed. 2, 33.!

SPECIES OF ORYZA GROWING IN WATER, LOWLAND RICE.

Oryza sativa binamban Blanco, ed. 1, 273; ed. 2 = Oryza sativa Linn.! T., Binambang.

Oryza sativa lamuyo Blanco, ed. 1, 273; ed. 2, $190=$ a variety of the preceding species.! T., Lamuyo.

Oryza sativa glutinosa Blanco, ed. 1, 273; ed. 2, 190. Retained by Villar as a distinct species, Oryza glutinosa Lour. Certainly a variety of Oryza sativa Linn. T., Malagquit.

Oryza aristata Blanco, ed. 1, 274; ed. 2, 190. Reduced by Villar to Oryza montana Lour. Certainly a variety of $O$. sativa Linn.!

SPECIES OF ORYZA GROWING IN DRY PLACES, UPLAND RICE.

Oryza sativa praecox Blanco, ed. 1, 274; ed. 2, 190. Retained by Villar as a distinct species, Oryza praecox Lour. Certainly a variety of O. sativa Linn.! 'T., Dumali.

Oryza sativa quinanda Blanco, ed. 1, 274; ed. 2, $191=$ Oryza sativa Linn., var.! T., Quinanda.

Oryza sativa pilosa Blanco, ed. 1, 275; ed. 2, 191. Retained by Villar as a distinct species, Oryza latifolia Desv. Certainly a variety of Oryza sativa Linn.! T., Bolohan.

Oryza sativa rubra Blanco, ed. 1, 275; ed. 2, $191=$ Oryza sativa Linn. var. T., Malagquit.

Oryza sativa violacea Blanco, ed. 1, 275; ed. 2, $191=$ Oryza satira Linn. var.! T., Tangi. 
Arundo tecta 13lanco, ed. 1, 48; ed. 2, 33, non Walt. = Phragmite's communis Trin.! Reduced by Villar to Phragmites roxburghii Steud., which is a synonym of Phragmites karka 'Trin. T., Tambo.

Cyperus paniculatus Blanco, ed. 1, 32; ed. 2, 22, non aliorum = Eragrostis tenella R. et S.! T., Caliraorao.

Bambus pungens Blanco, ed. 1, 270; Bambus arundo Blanco, ed. 2, 188. Reduced by Villar to Bambusa arundinacea Willd., which is probably correct. T., Cauayangtotoo.

* Bambus lima Blanco, ed. 1, 271; ed. 2, 189. Reduced by Villar to Bambusa longinodis Miq., but without good reason. Plant ten to fifteen feet high. T., Anos.

* Bambus textoria Blanco, ed. 1, 270; ed. 2, 188. Reduced by Villar to Gigantochloa ater Kurz, but without good reason. T., Calbang.

Bambus diffusa Blanco, ed. 1, 269; ed. 2, $187=$ DinocirloA DIFFusA (Blanco). Reduced by Villar to Schizostachyum acutiflorum Munro. T., Osiu, Bocavi.

* Bambus monogyna Blanco, ed, 1, 286; ed. 2, 187. Reduced by Villar to Dendrocalamus strictus Nees, which may be correct. T., Cauayang quiling.

* Bambus mitis Blanco, ed. 1, 271; ed. 2, 188. Reduced by Villar to Dendrocalamus sericeus Munro, which is certainly an error. T., Tiauanac.

* Bambus lumampao Blanco, ed. 1, 272; ed. 2, 189. Reduced by Villar to Dendrocalamus membranaceus Munro, which is probably an error. 'T., Lumampao, Bocaui.

* Bambus levis Blanco, ed. 1, 272; ed. 2, 189. Reduced by Villar to Dendrocalamus flagellifer Munro, which is probably an error. T., Cauayang boo.

\section{LYCOPODIACEAE.}

* Lycopodium gnidioides Blanco, ed. 1, 824; ed. 2, 569, non Linn. Reduced by Villar to Lycopodium selago Linn., which is certainly an error. An epiphyte. T., Pacayomcom.

* Lycopodium dichotomum Blanco, ed. 2, 570. Reduced by Villar to Lycopodium cernuum Linn., which is probably an error. Blanco's specimens were from plants cultivated in Manila.

\section{MARSILEACEAE.}

* Marsilea minuta Blanco, ed. 1, 834; ed. 2, 577, non ? Linn. Considered by Villar to be the Linnean species, which is doubtful. Blanco's specimens were from Pasig, near Manila, and from the Province of Batangas and other places, March.

Marsilea trifolia Blanco, ed. 1, 835; ed. 2, 577. Reduced by Villar to Pilularia globulifera Linn., which may be correct. January. 


\section{FIJICES.}

* Myriotheca arborescens Blanco, ed. 1, 831; ed. 2, 575. Reduced by Villar to Cyathea integra J. Sm. If this is correct Blanco's name is the earlier. T., Calatondon.

* Adiantum falcatum Blanco, ed. 1, 833; ed. 2, 576, non Sw. Reduced by Villar to Lindsaya retusa Mitten., which may be correct. Blanco's specimens were from Mandaloyon, near Manila.

* Adiantum lancea Blanco, ed. 1, 833; ed. 2, 576, non aliorum. Reduced by Villar to Lindsaya ensifolia Swartz, which may be correct.

Adiantum philippinense Blanco, ed. 1, 831; ed. 2, 575, non Linn. $=$ Adiantum lunulatum Burm.! T., Culantrillo, Lamot lamotan, Gayoman manoc, Caicai. P., Culantrillo. I., Dalipaco.

Adiantum tenuifolium Blanco, ed. 1, 832; ed. 2, 575. Reduced by Villar to a variety of the preceding species, which is probably correct.

Adiantum lyratum Blanco, ed. 1, 832; ed. 2, 575. Reduced by Villar to Adiantum caudatum Linn., which may be correct.

Coenopteris quadripinnata Blanco, ed. 1, 833; ed. 2, $576=$ Onychium. auratum Kaulf.! T., Pacong anuany, Diladila.

* Pteris grandifolia Blanco, ed. 1, 829; ed. 2, 574. Reduced by Villar to Pteris opaca J. Sm., which may be correct. T., V., Dagabas, Darias, Tagabas.

Naias obvoluta Blanco, ed. 2, $460=$ Ceratopteris thatiet roides Brongn.!

* Allantodia pinnata Blanco, ed. 2, 571. Reduced by Villar to Asplenium brackenridgei Baker, which may be correct. Blanco's specimens were from Mandaloyon, near Manila, where he states that it is very common.

Hemionitis incisa Blanco, ed. 1, 829; ed. 2, 574=Asplenium esculentum Presl.! T., Paco.

Pteris piloselloides Blanco, ed. 1, 830; ed. 2, 574. Reduced by Villar to Vephrolepis acuta Presl., which is probably correct.

* Pteris trichomanoides Blanco, ed. 1, 830; ed. 2, 574. Reduced by Villar to Nephrodium ramosa Moore, which is certainly an error. A foot high, growing on roofs.

* Polypodium serratum Blanco, ed. 1, 827; ed. 2, 572. Reduced by Villar to Nephrodium floccigera Moore, which may possibly be correct. Said by Blanco to be very common.

* Pteris sinuata Blanco, ed. 1, 830; Polypodium adiantiforme Blanco, ed. 2, 573. Reduced by Villar to Nephrodium davallioides Kunze, which may be correct. A fern three feet high.

Polypodium phymatodes Linn. Blanco, ed. 1, 827; ed. 2, 572.!

Polypodium quercifolium Linn., Blanco, ed. ], 827; ed. 2, 572.! T., Pacpac lauin, Paipai amo. V., Cabacbun, Cabcab, Cabcaban. P., Gona, Tibatib. I., Capacapa. 
* Polypodium signatum Blanco, ed. 2, 5i2; Pteris signata Blanco, ed. 1, 830. Reduced by Villar to Polypodium albo-squamatum Blume, which must be considered as doubtful. Blanco's specimens were from Mandaloyon, near Manila.

Ugena semihastata Blanco, ed. 1, 822; ed. 2, 56s. Reduced by Villar to Lygodium dichotomum Swartz, which is probably correct. T., Nito.

Ugena alba Blanco, ed. 1, 823; ed. 2, 569. Reduced by Villar to Lygodium scandens Swartz, which is probably correct. 'T., Nitong puti.

Helminthostachys dulcis Kaulf, Blanco, ed. 2, $596=$ Helminthostachys zeylanica Hook.! T., Tocorlanguit.

* Achrostichum simplex Blanco, ed. 1, 826; ed. 2, 571. This species is not cited by Villar by name but from the page citations, it is the species he intends to refer to Achrostichum latifolium Swartz, which reference is very doubtful.

* Achrostichum tripinnatum Blanco, ed. 1, 826; ed. 2, 571. Reduced by Villar to Achrostichum apiifolium Hook., which may be correct. Blanco's specimens were from Malinta, near Manila.

Achrostichum lagolo Blanco, ed. 1, 826 ; ed. 2, $720=$ Achrostichum aureum Linn.! T., Lagolo.

Blechnum colubrinum Blanco, ed. 1, 834; ed. 2, $576=$ OleaxDRA COLUbrina (Blanco) Copeland.! A species related to Oleandra neriiformis Cav., to which it was reduced by Villar. It is represented by No. 3238 Merrill. T., Lunas.

\section{CELLULAR CRYP'TOGAMS.}

Villar makes no attempt to identify the few species of cellular cryptogams described by I3lanco, but for completeness the list is here given.

* Marchantia ed. 1, 835; ed. 2, 577. Generic description only.

* Tremella, ed. 1, 837; ed. 2, 578. Generic description only.

* Agaricus, ed. 1, 845; ed. 2, 583. Generic description only, which also includes Polyporus. I., Colatcolat.

* Sclerotium subterraneum Blanco, ed. 1, 845; ed. 2, 584. A fungus found in the nests of the anay, white ant.

* Fucus prolifer Blanco, ed. 1, 838; ed. 2, 579.

* Fucus denticulatus Blanco, ed. 1, 839; Fucus natans Blanco, ed, 2, 579.

* Fucus gulaman Blanco, ed. 1, 839; Fucus edulis Blaneo, ed. 2, 580. T., Gulaman.

* Ulva umbilicalis Blanco, ed. 1, 852; ed. 2, 581.

* Ulva compressa Blanco, ed. 1, 842; ed. 2, 581.

* Ulva reticulata Blanco, ed. 1, 842; ed. 2, 582.

* Ulva intestinalis Blanco, ed. 1, 842; ed. 2, 582.

* Conferva littoralis Blanco, ed. 1, 843; ed. 2, 582.

* Conferva setosa Blanco, ed. 1, 844; ed. 2, 582. 


\section{UNDETERMINED SPECIES.}

* Cynomorium philippinense Blanco, ed. 1, 665; ed. 2, 464. Blanco's specimens were from Cebu. V., T., Capulao.

* Erotium lanigerum Blanco, ed. 1, 440; ed. 2, 307. Blanco's specimens were from Cebu. V., Hagonoi sa lasang.

* Kleinhovia serrata Blanco, ed. 1, 653; ed. 2, 456. Blanco's specimens were from Pasig, Province of Rizal, a shrub or small tree, flowering in September.

* Legnotis lanceolata Blanco, ed. 1, 445. This species is not listed in Index Kewensis, and I have been unable to find the species in the second or third editions of the Flora de Filipinas or in the Novissima Appendix. Blanco's specimens were from Cebu, a tree flowering in February. V., Barit.

* Nama jamaicensis Blanco, ed. 1, 211; ed. 2, 148, non Linn. Perhaps Blanco's material was from some cultivated species. 


\section{INDEX TO NATIVE NAMES.}

\begin{tabular}{|c|c|c|c|}
\hline Abacá & $\begin{array}{r}\text { Page. } \\
83\end{array}$ & Alocasoc. & $\begin{array}{r}\text { Page. } \\
69\end{array}$ \\
\hline Abangabang & 33,66 & Alodig .... & 78 \\
\hline Abilo & 30 & Alpai . & 35 \\
\hline Ábur & 86 & Alum & 78 \\
\hline Acapulco & 41 & Alupai & 35 \\
\hline Achiote ... & 18 & Alyopyop ......... & 67 \\
\hline Acle & 42 & Amadiong ....... & 91 \\
\hline Adaan & 42 & Amaga & \\
\hline Adelfa & 59 & Amarai ............. & 81 \\
\hline Adgao & 68 & Amargoso ..... & 49 \\
\hline Adiavan & 88 & Amarillo & 56 \\
\hline Agaiyangyang & 38 & Amoguis & 36 \\
\hline ga & 31 & Amolong & 90 \\
\hline ................. & 68 & Amores secos. & 92 \\
\hline (1) & 62,81 & Amp & 49 \\
\hline (n) & 78 & Amuyon & 17 \\
\hline 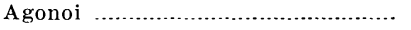 & 55 & Anabo & 23 \\
\hline Agoo & 81 & Anabon $\ldots . . . \ldots \ldots . . . .$. & 25 \\
\hline ........... & 91 & Anag & 30 \\
\hline$\ldots \ldots .$. & 79 & & 43 \\
\hline 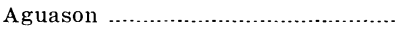 & 61 & Ana & 30 \\
\hline ngai & 91 & Anahao ............. & 88 \\
\hline$\ldots \ldots \ldots \ldots \ldots \ldots$ & 30 & ngtang & 30 \\
\hline Ahihiro ....................... & 42 & 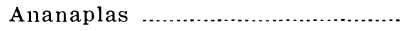 & 42 \\
\hline (n)...................... & 79 & $(-\ldots \ldots \ldots \ldots \ldots$ & 88 \\
\hline & 68 & & 83 \\
\hline (1) & 42 & ........... & 43 \\
\hline ang ....................................... & 16 & Angud $\ldots \ldots \ldots \ldots$ & 71 \\
\hline ang sonson ………................... & 16 & $\tan$ & 29 \\
\hline$\ldots \ldots \ldots \ldots \ldots$ & 62 & ........... & 25 \\
\hline$\ldots \ldots \ldots$ & 62 & Anibong. & 25 \\
\hline s & 89 & Anii & 39 \\
\hline Alayan .......................................... & 81 & Anilao & 26 \\
\hline Albaricoques & 43 & Anis cahoi ........................ & 73 \\
\hline 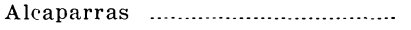 & 18 & moscada & 73 \\
\hline & 29 & Anitap & 42 \\
\hline 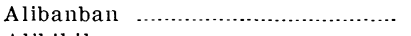 & 42 & Anito & 69 \\
\hline 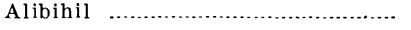 & 42 & 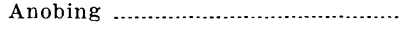 & 80 \\
\hline 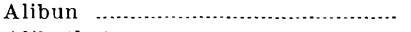 & 55 & Anobing caguiosing ........................... & 80 \\
\hline & 59 & Anobion & 80 \\
\hline gon & 87 & 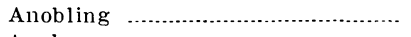 & 15,80 \\
\hline . & 78 & 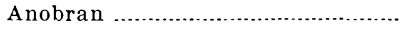 & 68 \\
\hline Alingaro & $7 \pm$ & Anonang & 62 \\
\hline 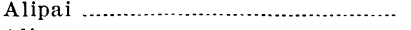 & 35 & 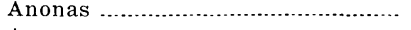 & 16 \\
\hline 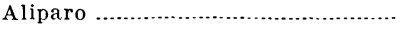 & 77 & & 93 \\
\hline 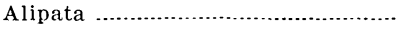 & 78 & Ansohan & 66 \\
\hline-7 & & 97 & \\
\hline
\end{tabular}




\begin{tabular}{|c|c|c|c|}
\hline & $\begin{array}{r}\text { Page. } \\
30\end{array}$ & Bahai & $\begin{array}{r}\text { Page. } \\
39\end{array}$ \\
\hline Antipolo ……........................... & 80 & Baino ...... & 17 \\
\hline Antolang & 67 & Bait & 75 \\
\hline Antolangan & 23 & 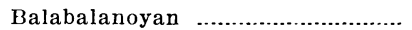 & 17,18 \\
\hline Anuang & 83,90 & Balabalayan & - 68 \\
\hline Apalaya & 49 & Balacat & 33 \\
\hline Apalia .. & 49 & 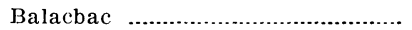 & 48 \\
\hline Apalit & 40 & Baladre & 59 \\
\hline Apariagua & 80 & 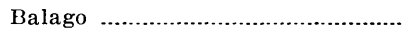 & 19 \\
\hline Apatot & 54 & Balaibai & 69 \\
\hline pis & 89 & 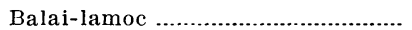 & 53 \\
\hline Apiton & 21 & 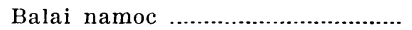 & 18 \\
\hline Apoiapoyan & 17,18 & Balangot & 90 \\
\hline Apon & 90 & 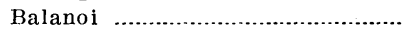 & 69 \\
\hline Aposotis & 71 & Balanti & 77 \\
\hline Apulid . & 91 & Balao & 21 \\
\hline Arandon .. & 74 & Balasbas & 67 \\
\hline raña & 18 & 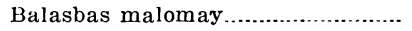 & 67 \\
\hline (1) & 55 & in & 17 \\
\hline 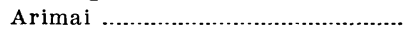 & 81 & i & 39 \\
\hline (1) & 60 & $\mathrm{~g}$ aso & 37 \\
\hline ................... & 81 & (1) & 41 \\
\hline Arodayday & 62 & ong & 41 \\
\hline in ....................... & 23 & Bali & 86 \\
\hline 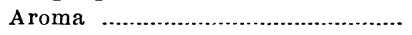 & 42 & (............... & 23 \\
\hline ................... & 38 & ............. & 42 \\
\hline 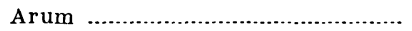 & 78 & ic & 40,60 \\
\hline (2) & 40 & Balicupcup & 90 \\
\hline 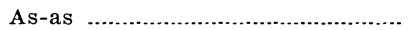 & 54 & & 69 \\
\hline (n) & 29 & 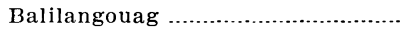 & 77 \\
\hline ........... & 79 & ............. & 92 \\
\hline Asuangai & 69 & $\mathrm{n}$ & 27 \\
\hline Ataiatai & 67 & 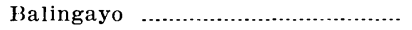 & 48 \\
\hline (2) & 16 & suai …............. & 87 \\
\hline Ausi & 19 & 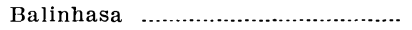 & - $\quad 36$ \\
\hline ............. & 42 & itan & 41,57 \\
\hline Ayantoto & 71 & i & 78 \\
\hline Ayapana & 55 & Baloyoco & 92 \\
\hline Aуо & 27,33 & ............... & 45 \\
\hline - & 55 & .............. & 76 \\
\hline $\mathrm{Azu}$ & 85 & & 29 \\
\hline (n) & 43,44 & Balod ... & 52 \\
\hline Bacauan & 43,44 & Balogo ........ & 42 \\
\hline 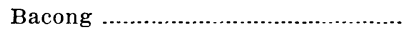 & 85 & Balo & 74 \\
\hline 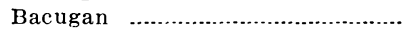 & 30 & …....... & 76 \\
\hline 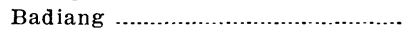 & 90 & & 84 \\
\hline Badiara & 69 & Banaba …............. & 47 \\
\hline Badoc & 55 & Banabanalo ... & 24,73 \\
\hline Bagaboboi & 68 & …...... & 87 \\
\hline (.). & 57 & & 20,23 \\
\hline 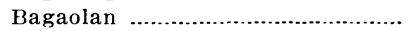 & 51 & oanai & 15,66 \\
\hline 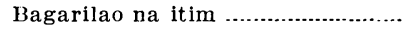 & 52 & Banalo & 23,61 \\
\hline 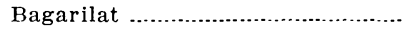 & 52 & Banaro & - 23 \\
\hline & 62 & & 28 \\
\hline & 2 & & 52 \\
\hline (2) & 68 & & 54 \\
\hline 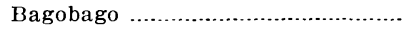 & 20,54 & 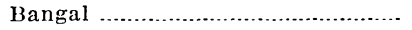 & 82 \\
\hline Bagombon & 84 & Bangar ....... & 24 \\
\hline 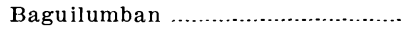 & 76 & 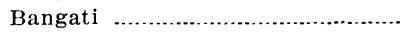 & 38 \\
\hline
\end{tabular}




\begin{tabular}{|c|c|c|c|}
\hline & Page. & & Page. \\
\hline & 56 & Bitlag . & \\
\hline & 52 & Bitnong ... & \\
\hline 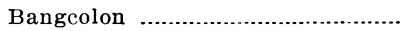 & 34 & Bitógo ..................... & \\
\hline 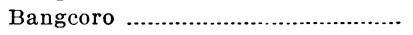 & 54 & Bitongol .................. & \\
\hline 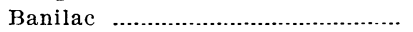 & 44 & 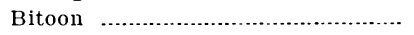 & \\
\hline 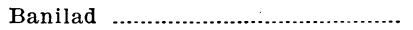 & 24 & Bitung & \\
\hline - & 24 & Boboa ….......................... & \\
\hline anot .... & 42 & Boboi . & \\
\hline anquilin ............................. & 76 & Boboi gubat ........ & \\
\hline 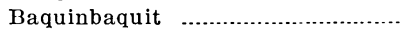 & 25 & 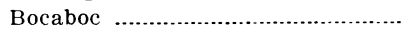 & \\
\hline 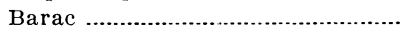 & 84 & 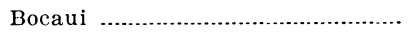 & \\
\hline 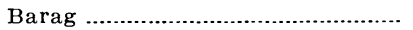 & 87 & 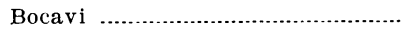 & \\
\hline 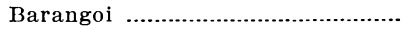 & 88 & Bog & \\
\hline (1) & 45,96 & Bol & \\
\hline Batad …........................................ & 92 & & \\
\hline 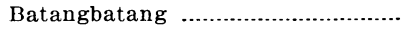 & 17 & 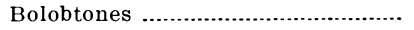 & \\
\hline . & 40 & n & \\
\hline - & 83 & (1) & \\
\hline 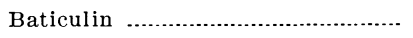 & 66,74 & 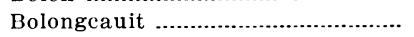 & \\
\hline (1) & 59 & & \\
\hline 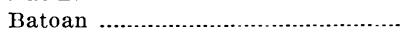 & 36 & 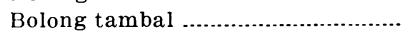 & \\
\hline 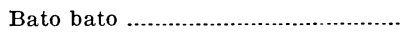 & 63,74 & ong & \\
\hline is & 75 & & \\
\hline 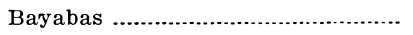 & 45 & & \\
\hline ing & 41 & & \\
\hline - & 59 & & \\
\hline ang $\quad$ ………....................... & 71 & 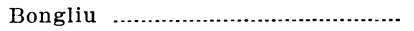 & \\
\hline - & 54 & (1) & \\
\hline 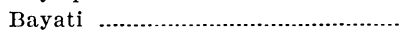 & 17 & & \\
\hline (1) & 25 & (n).................. & \\
\hline 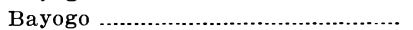 & 4 & & \\
\hline - & 45 & (...................... & \\
\hline noche & 70 & $\mathrm{n}$ & \\
\hline . & 57 & & \\
\hline ................................. & & (1) & \\
\hline 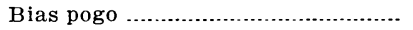 & 47 & $\ldots \ldots \ldots \ldots \ldots \ldots$ & \\
\hline (2) & 90 & ............ & \\
\hline 0 & 76 & 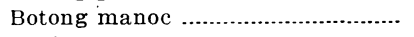 & \\
\hline bilang & 50 & 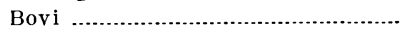 & \\
\hline 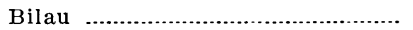 & 78 & ……....... & \\
\hline (1) & 62 & (n).................... & \\
\hline 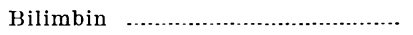 & 27 & (n............... & \\
\hline - & 32 & $\ldots \ldots \ldots \ldots \ldots \ldots$ & \\
\hline ng : : - & 92 & .................... & \\
\hline & 74 & & \\
\hline & 78 & & \\
\hline ......... & 30,51 & 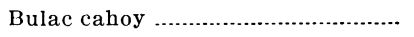 & \\
\hline & 83 & & \\
\hline n & 60 & lonti & \\
\hline . & 78 & 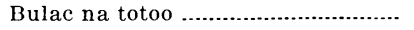 & \\
\hline - & & & \\
\hline (1) & 2 & & \\
\hline & 20 & (n)................ & \\
\hline - & 56 & . & \\
\hline . & 39 & (....................... & \\
\hline 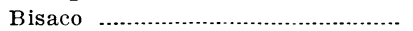 & 90 & & \\
\hline & & & \\
\hline & 20 & & \\
\hline 3itaog & 20 & & \\
\hline
\end{tabular}




\begin{tabular}{|c|c|c|c|}
\hline Buquiquit & $\begin{array}{r}\text { Page. } \\
38\end{array}$ & Calayate & $\begin{array}{r}\text { Page. } \\
67\end{array}$ \\
\hline Buracan ... & 63 & Calbang & 93 \\
\hline Buri ....... & 88 & Caliantang ..................... & 33 \\
\hline 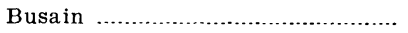 & 24 & Calimbahin & 45 \\
\hline 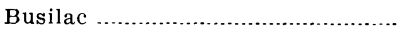 & 31,77 & Calinga & 73 \\
\hline Buta ........ & 78 & Calingad & 73 \\
\hline Butabuta & 78 & Calingag & 73 \\
\hline Buttingi & 39 & Calios .................... & 78 \\
\hline Buyayava & 75 & Calipayang & 77 \\
\hline Buyo & 72 & 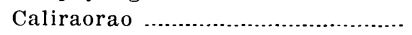 & 93 \\
\hline Buyọcbuyoc ....... & 49 & Calisai & 44 \\
\hline 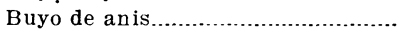 & 72 & Calitcalit ............................ & 33 \\
\hline $\mathrm{g}$ & 47 & Calites ..... & 71 \\
\hline Cabacbun & 94 & Calobcob & 45 \\
\hline 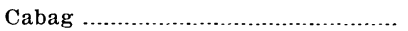 & 52 & tingan ............................. & 25 \\
\hline abai & 40 & la & 26 \\
\hline $\mathrm{Cab}$ & 61 & & 28 \\
\hline 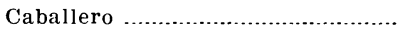 & 41 & ndagui ..................... & 75 \\
\hline (2) & 26 & Caloo. & 38 \\
\hline ti & 33 & mban $\ldots \ldots \ldots \ldots . . . . . .$. & 76 \\
\hline .......... & 94 & Cal & 24 \\
\hline$\ldots \ldots \ldots \ldots \ldots \ldots \ldots$ & 94 & $\mathrm{Ca}$ & 51 \\
\hline n …… & 55 & 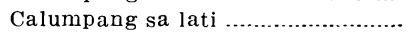 & 31 \\
\hline Cabeza negrito & 91 & it & 44 \\
\hline 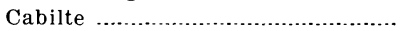 & 26 & gai $\ldots \ldots \ldots \ldots \ldots \ldots . . . . . . . .$. & 36 \\
\hline Cablin & 70 & & 86 \\
\hline ............ & 16 & & 33 \\
\hline g & 76 & bat $\ldots \ldots \ldots \ldots \ldots \ldots$ & 87 \\
\hline (2) & 39 & 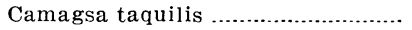 & 36 \\
\hline ba & 56 & & 77 \\
\hline asan & 84 & & 41 \\
\hline 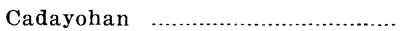 & 71 & $\mathrm{Ca}$ & 36 \\
\hline $\mathrm{n}$ & 70 & $\mathrm{Can}$ & 37 \\
\hline Cadlom & 70 & uianis & 28 \\
\hline Café & 54 & 1i & 27 \\
\hline Caguois & 40 & Can & 84 \\
\hline $\mathrm{Cal}$ & 29 & & 56 \\
\hline Caic & 94 & ang songsong ........................... & 70 \\
\hline ad & 17 & s & 63 \\
\hline Calabazang bilog & 50 & ; & 27 \\
\hline a & & Can & 62 \\
\hline Imayan & 17 & & 36 \\
\hline chuchi & 59 & abag ……………................. & 41 \\
\hline 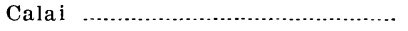 & 16 & 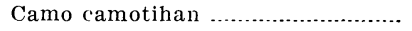 & 62 \\
\hline & 38 & es & 43 \\
\hline & 30 & $\mathrm{C}$ & 80 \\
\hline anai & 44 & & 43 \\
\hline 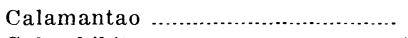 & 76 & Camoti ................... & 62 \\
\hline 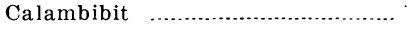 & 41 & Camoting cahoy & 77 \\
\hline & 27 & & 58 \\
\hline & 40 & & 3,59 \\
\hline - & 29 & & 28 \\
\hline Calangcang & 51 & Candaroma & 73 \\
\hline Calantas & 31 & Candon & 47 \\
\hline (2) & 53,88 & & 47 \\
\hline (1) & 35 & & 62 \\
\hline (1) & 59 & 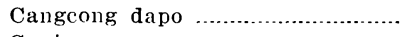 & 48 \\
\hline 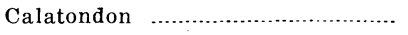 & 94 & 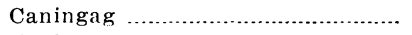 & 16 \\
\hline Calavaga. & 83 & Canlara & 61 \\
\hline
\end{tabular}


Canomai

Canomoi

Cansasaga

Cantotai

Cantotan

Canubsuban

Canucsuban

Caña dulce

Cañafistula

Capacapa

Capalcapal

Capas

Capili

Capitcabag

Capopot visaya.............................

Capulao

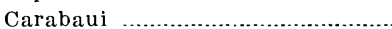

Carachucha

Caragli

Carahumai

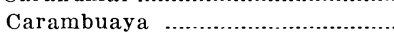

Carampalit

Carangcang

Carisquis

Carlin

Caro

Carot

Carucansoli

Casabha

Casindac

Casitas .

Casla

Casopanguil

Casopanguil gubat .......................

Casoy

Castiocastiogan ....................................

Castoli ............................................

Casubha ........................................

Casubhang aso .............................

Casung

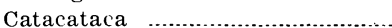

Catalonga

Catanda

Catandang aso

Catangal

Catang catang

Catcatan

Catiquis

Catluen

Catmon

Catongal

Catotang

Catuit

Caturai

Cauayang boo

Cauayang quiling

Cauayang totoo

Cauon

Cavilan

Cayangcan ...................................... 51

Cayaocayao ................................ 59

Cayutana ..................................... 27

Cebollas del monte ..................... $\quad 84$

Cebollas de persia ........................ 85

Chachachachahan ...................... 65, 67

Chicos ...................................... 57

Cibicibollasan ............................ 91

Cinamomo .................................... 47

Cinco llagas ................................. $\quad 67$

Cintascintasan ......................... $\quad 82$

Cobag ........................................ $\quad 86$

Cocong manoc ............................. 66

Codamba .................................... 61

Cogon .......................................... 92

Cogon cogon.................................... 92

Colasiman ................................... 19

Colatcolat ................................. 95

Coles maluco ............................... $\quad 70$

Colis ........................................... 47

Colo ............................................. 80

Colobot ........................................ 29

Colocanting ................................. 40

Colocolog .................................... $\quad 69$

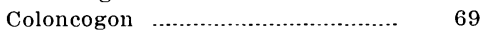

Colongcolong ................................ 74

Colotan ....................................... 23

Colotan bilog .............................. 26

Colotcolotan .............................. 23

Combarcombaran ......................... 69

Comimpol .................................. 26

Comintan ..................................... 44

Condol ....................................... 49

Consuelda .................................... 75

Copang .......................................... 42

Copcop ........................................ 45

Corazon de Angel ......................... 86

Corot ........................................ 86, 90

Cotingcotingan ........................... 62

Cuacuacohan ............................... 23

Cuanton ....................................... 71

Cubatili ....................................... 31

Cubili ......................................... $\quad 35$

Cuchai ..................................... 87

Cucubitan ................................... 49

Culantrillo ................................. 94

Culasi ....................................... 44

Culatai ........................................ 58

Culiat ....................................... 82

Culit .......................................... 54

Cungi .......................................... 27

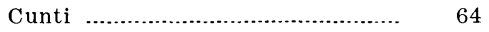

Cupit cupit ................................. 63

Curagda ........................................ 49

Curribuetbuet .............................. 59

Cuscusipa ..................................... 17

Cusiben 


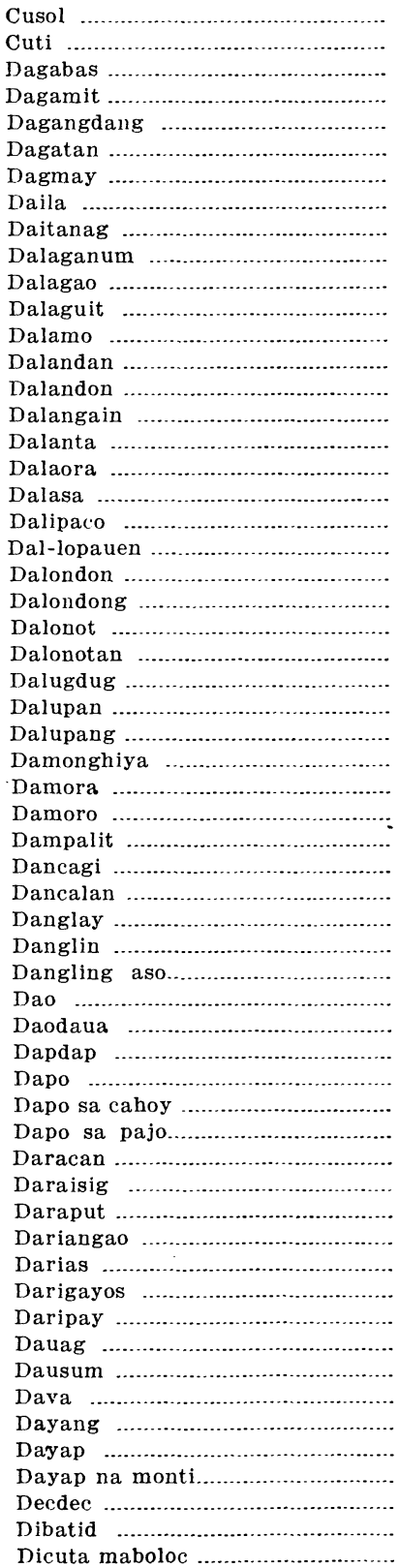

Page.

Page.

84: Diego de noche........................... 70

64. Digquit digquit ........................... 70

94 Diis .......................................... 42

43 Diladila ......................................... 94

37 Dilang baca ................................. 50

65 Dilang boaya .............................. 87

90 Dilang butiqui .............................. 52

90 Dilang usa .................................... 55

40 Dilan usa ................................... 62

16 Dilao .................................... 83

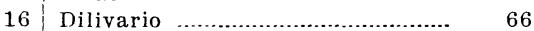

78 Dincalan ..................................... 20

80 Dinglas ........................... 44, 46, 73

29 Dinuguan .................................. 83

68 Dirig ......................................... 35

80 Dita ........................................... 59

33 Dit-an ......................................... 88

67 Docotdocot ................................ 71

44 Dolariu ..................................... 66

94 Doldol .......................................... 24

59 Dolongain .................................... 80

67 Dongon ...................................... 24

57 Dool .......................................... 36

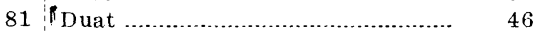

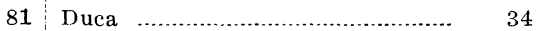

41 Duclap .................................... 33

23 Duclitan ................................... 57

23 Ducum ......................................... 23

27 Duguan ....................................

50 Duha ......................................... 24

80 Duhat .................................... 46

50 Dulao .......................................... 83

61 Dulauari ..................................

20 Dulian ........................................ 86

68 Dulitan ...................................... 57

26 Dumali ......................................... 92

25 Dumayaca .................................. 88

36 Durang parang ............................ 37

80 Dusod ......................................... 84

39 Duso ............................................ 84

\begin{tabular}{l|l}
74,84 & Dusog $\ldots \ldots \ldots \ldots \ldots \ldots \ldots \ldots \ldots \ldots \ldots \ldots \ldots \ldots \ldots \ldots \ldots \ldots \ldots \ldots \ldots \ldots \ldots \ldots \ldots$
\end{tabular}

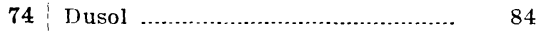

75 Escobang bilog .......................... 23

57 Escobang haba ........................... 23

27 Espada ...................................... 82

29 Fariqtan ................................... 84

42 Flor de campana ........................ 66

94 Flores ..................................... 41

20 Frijoles del Abra ...............................

62 Fruta ......................................... 61

18 Gabigabihan ........................... 90

86 Gabing ouac ............................. 90

91 Gabuen ....................................... 55

66 Gaby ........................................ 90

28 Galamai amo ............................ 51

28 Galamai señora ........................... 83

32 Galiang ................................... 90

90 Galonalpas .................................. 91

54 Gamagamatisan ....................... 64 
Gamot sa buni

Ganda

Gandus

Gaogao

Gapasgapas

Garbanzos

Garban

Gatasgatas

Gavai gavai

Gávay

Gayoman manoc ............................

Gayos

Gicos gicos

Gloria

Gogo

Gogong bacay

Gogong bisaya

Gogong toco

Golandrina

Gomamila

Gona

Goyoran

Grana

Granada

Grano del parayso

Guanabanos

Guicos guicos

Guijo

Guilalas

Guinabang

Guinguen

Guintenguinten

Guisan

Guisian

Guisihan

Guiso

Guisol

Guisong dilao

Gulaman

Guling gulingab

Guyabas

Guyongguyong

Habas

Habul

Hagonoi

Hagonoi sa lasang...........................

Hagorilis

Haguimit

Hagupit

Halahala

Halon

Hamaraon

Hamitanag

Hamlibon

Hampas tagbalang ........................

Hampas tigbalang .........................

Hanambabao

Hanarion

Hanbabalos
Page.

41
Handaramai

Page.

Hangor

Hangot

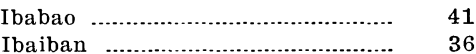

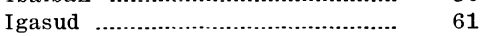

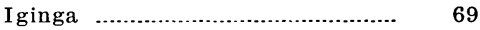

Iguiu ...................................... 30

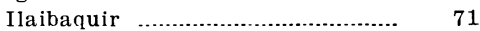

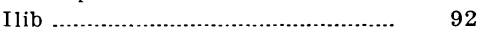

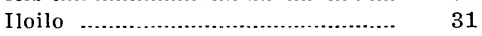

Inalai ....................................... 90

Inignin ..................................... 48

Ipil .............................................. 41

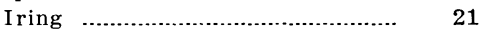

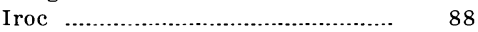

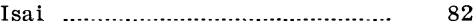

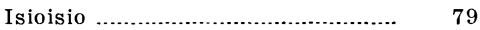

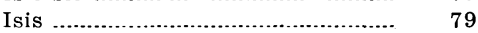

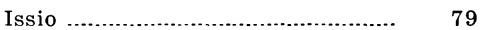

Itmo ........................................... $\quad 72$

Itmong ouac ............................... 82

Labba labba.................................. 33

Labni .......................................... 88

Labnis ......................................... 81

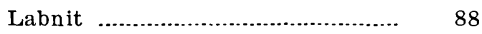

Labon ............................................. $\quad 25$

Lacad bulan................................. 55

Lacatan ....................................... $\quad 83$

Lacdanbulan .............................. 55 


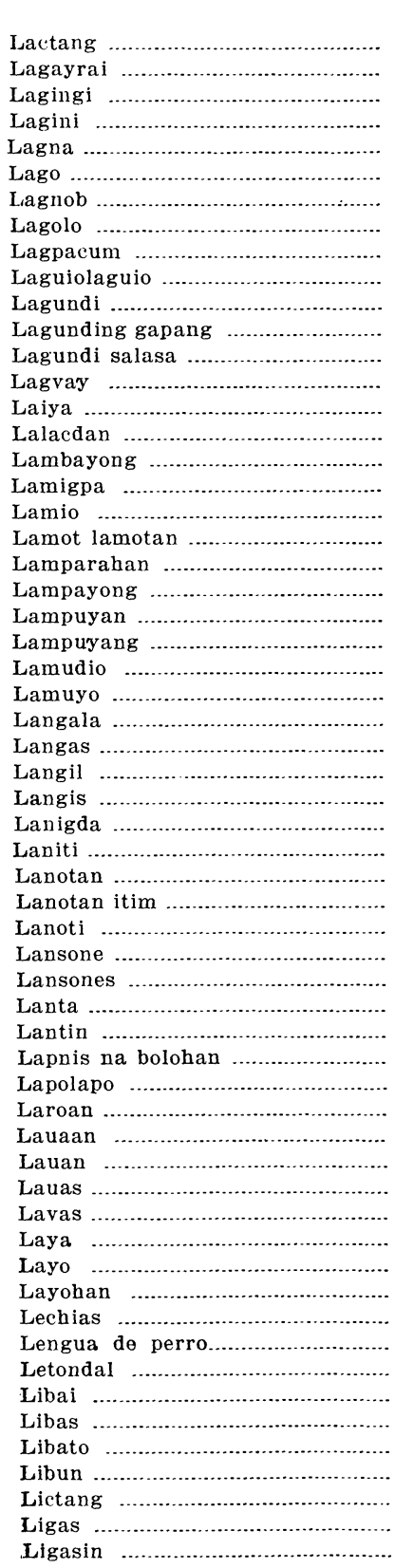

Page.

Lilitan

Page.

Limalima

Limang sugat

51,86

Limoncitos

Lingalingahan

Lingasina

Lingaton ...................................

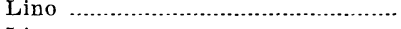

Linog .......................................

Lintang baguin ............................

Lipa ........................................... 80

55 Lipai ........................................ 38, 80

62 Lipang castila ............................. 80

31 Lipang doton ............................... 80

36 Lipata ......................................... 78

94 Litbit .......................................

82 Litlit ........................................ 72

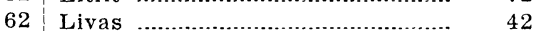

83 Loba ........................................ 33

84 Lobalob .................................... $\quad 75$

50 Lobas ........................................... 46

92 Lobio ...........................................

80 Locloquisin ............................... 61

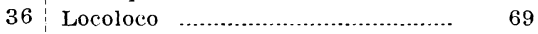

42 Lollod lohod ................................ 87

66 Loloan .......................................

31 Loloi .......................................

59 Lombayong ............................... 41

16 Lomonai .....................................

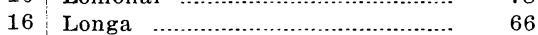

33 Lopa

31 Lovian ...................................... 81

31 Lubilubi ................................. 35,64

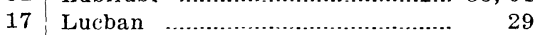

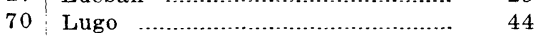

23 Lumampao .............................. 93

45 Lumban .......................................

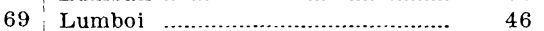

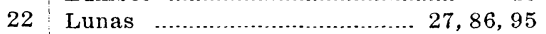

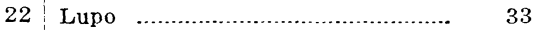

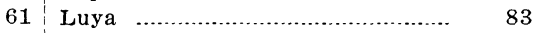

17 Luyang osiu ............................... 83

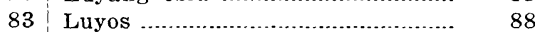

$58 \quad$ Maasic ........................................... 37

\begin{tabular}{l|l|l}
76 & Mabatang dicut ............................... & 54
\end{tabular}

35 Mabolo .......................................... 58

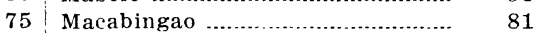

83 Macabuhay ............................... 17

71 Macahiya .............................. 27, 42

49 Macaisa ....................................... 29

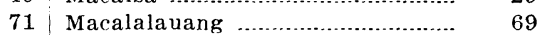

56 Macalingag ................................. 73

17 Macan ......................................... 51

36 Macapil ..................................... 40

44 Maca sampaloc ........................... 41 
Page.

Macupa

Malimali

Page.

Madondon .....................................

Madre cacao

Magatas

Magsaloro

Magtabig

Magtambocao

Magui

Mahahiin

Maisipaisa

Maiz

Malaanonan

Malaapi

- Malaapolid

Malaas-is

Malabachao

Malabaguio

Malabalugbug daguis

Malabangao

Malabatoan

Malabayabas

Malabocboc

Nalabohoc

Malabonga

Malabulac

Malabunot

Malacabuyao

Malacadog

Malacaguo is

Malacatmon

Malaclac

Maladosos

Malagoso

Malagquit

Malaisis

Malaitmo

Malis ....................................... 23

Malisa ..................................... 72

75 Malismalis ................................ 75

86 Malongain .................................... 30

36 : Maluco ….....................................

39 Malungay …….............................. 36

85 Malungit ….................................. 36

27 Malva rosa ................................... 26

28 Malvas de Castilla ......................... 23

91 Mavindata ................................... 29

22 Malayantoc …….......................... 59

68 Malbas tagbalang ........................ 15

91 Mamalis …............................. 19, 23

53 Mambog …............................... 52, 54

75 Mamei …..................................... 57

32 Mamin ..................................... 72

27 Mamitic …................................... 66

30 Manon …................................... 72

20 Mampol ….................................. 43, 52

53 Mananantang ............................. 30

20 Mana-naog …............................... 61

74,81 Mananquil ................................. 45

74 Mandalusa .................................. 67

24 Manga ......................................... 35

24 Mangachapoi ............................... 22

29 Manga de an is ............................... 35

44 Mangadolong ................................. 38

38 Manga-pico …............................... 35

15 Mangasiriqui ….............................. 81

56 Mangipod ..................................... 88

67 Mani ............................................. 38

50 Manimanihan .............................. 41

92 Manquit ........................................ 38

78 Mantala ...................................... 40

Malaiyo

Malamayana

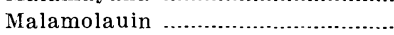

Malapaco

Malapacpac balavay .......................

Malapalitpit

Malapao

Malapapaya

Malapatopat

Malapotocan ……….........................

Malaracopcop …..............................

Malarayap

Manul ......................................... 58

36 Manungal …................................ 29

69 Manzanilla ................................... 56

28 Manzanitas ................................... 32

48 Marayapa ....................................... 69

$90 \quad$ Margoso ........................................... 49

34 Maricum ….................................. 23

21 Mariscos …................................. 92

51 Marisicos ........................................ 92

53 Maropoto ….................................... 23

68 Marucum ....................................... 23

45 Marulinao …................................ 42

32, 28 Matang arao ................................ 27

Malaruhat ................................... 46 Matang diablo ............................. 27

Malaruhat na pula ....................... 46 Matang olang ................................. $\quad 32$

Malasaga .................................... 40 Matangpune ................................ 38

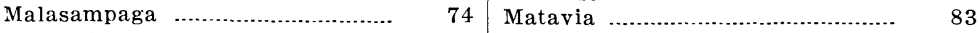

Malatibig ...................................... $\quad 21$ Mavindato ................................... 36

Malatinta ..................................... $\quad 76$ Mayana ..............................................

Malatumbaga …............................ 41, 45 Mayapis .............................................. 21

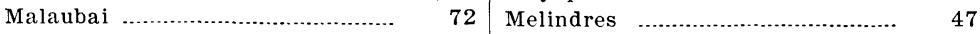

Malaubi ................................... $\quad 72$ Melon daga ................................ 50

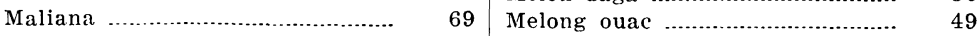

Malibago ….................................. $23 \quad$ Migi …........................................ 31 


\begin{tabular}{|c|c|c|c|}
\hline Mil leguas & $\begin{array}{r}\text { Page. } \\
60\end{array}$ & Pacapis …............... & $\begin{array}{r}\text { Page. } \\
69\end{array}$ \\
\hline Minonga ... & 78 & Pacayomcom. & 93 \\
\hline Mocasisi & 30 & Pacayomcom Castila …..................... & 41 \\
\hline Molauin & 68 & Paco & 94 \\
\hline Molavin & 28,68 & Pacong anuang & 94 \\
\hline 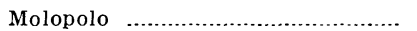 & 23 & 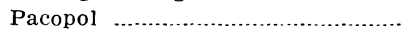 & 33 \\
\hline Molugoso …… & 50 & Pacpacbalang & 25 \\
\hline Mongomongohan & 41 & 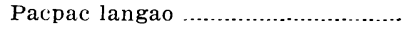 & 38 \\
\hline 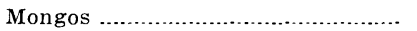 & 39 & 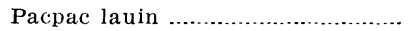 & 94 \\
\hline opio ............................ & 67 & Pacupis & 49 \\
\hline 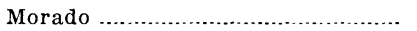 & 67 & Pagatpat & 47,57 \\
\hline Moradong maputi …............................ & 67 & Pagbut & 53 \\
\hline 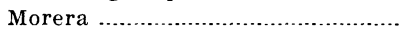 & 78 & Paipai amo & 94 \\
\hline Mostaza & 17 & Paipaisi & 70 \\
\hline 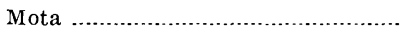 & 91 & 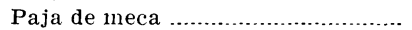 & 92 \\
\hline Mutha & 91 & Pajo & 35 \\
\hline Muthang & 90 & 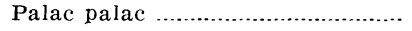 & 57 \\
\hline Nabo ......... & 25 & Paladpalad & 66 \\
\hline Nacboligan & 68 & Pala & 29 \\
\hline 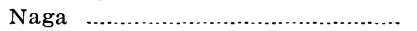 & 40 & Palagium ...... & 29 \\
\hline Nami $\ldots . . .$. & 86 & 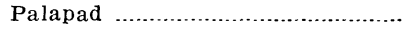 & 47 \\
\hline Nangea ....... & 80 & Palasan & 88 \\
\hline Narangitas ... & 29 & Palatpat & 47 \\
\hline - & 40 & (2. & 17 \\
\hline Nato & 24,44 & Palindan .. & 88 \\
\hline 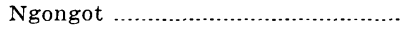 & 88 & Palis & 23,67 \\
\hline Nigui & 31 & Palla & 49 \\
\hline 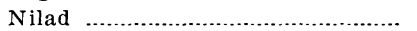 & 53 & (.) & 40 \\
\hline Nilar & 53 & Palo calai & 16 \\
\hline Nino & 54 & Palohambobocag …............................. & 30 \\
\hline Niog ........................ & 88 & Palo Maria ...................... & 20 \\
\hline Niogniogan & 45,80 & Palongpalongan & 71 \\
\hline (- & 88 & Palo Santo & 36,41 \\
\hline Nipai & 38 & 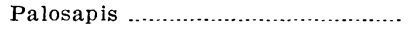 & 22 \\
\hline Nitong puti & 95 & hinhin ....... & 30 \\
\hline …............ & 78 & Palunai …........... & 55 \\
\hline Noog noog & 64 & Pamalatanguen & 53 \\
\hline Nopau & 72 & Pamalis ........................ & 23 \\
\hline Oas & 35 & Pamitlain & 20 \\
\hline Oayi & 88 & latin & 20 \\
\hline - & 87 & $\mathrm{t}$ & 68 \\
\hline Obispo & 83 & Pamulaclaquin & 44 \\
\hline 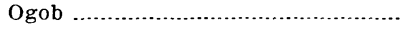 & 80 & 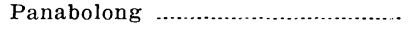 & 56 \\
\hline Olango & 89 & & 86 \\
\hline 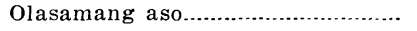 & 65 & la & 70 \\
\hline Olasiman & 19 & mpat & 24 \\
\hline Onava & 62 & Panao & 21 \\
\hline Onoran & 91. & Panaptun & 67 \\
\hline (1) & 64 & (1).......................... & 86 \\
\hline Oongon . & 44 & Pan & 17 \\
\hline Opo & 49 & Pancudo .......................... & 54 \\
\hline Oracion & 70 & Pandacaqui ............. & 59 \\
\hline Orayi & 71 & & 44,89 \\
\hline 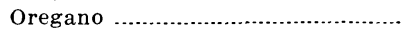 & 64,69 & Pandapanda .................... & 30 \\
\hline Osiu & 93 & Pandaya & 59 \\
\hline 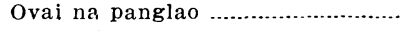 & 15 & Pangaguason & 61 \\
\hline 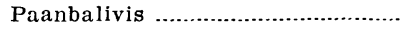 & 70 & Pangangtolong & 56 \\
\hline & 80 & 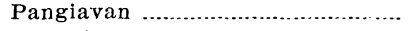 & 17 \\
\hline 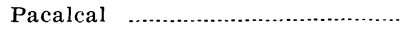 & 78 & Pangui ...... & 18 \\
\hline
\end{tabular}




\begin{tabular}{|c|c|c|c|}
\hline Pansipansi & $\begin{array}{r}\text { Page. } \\
70\end{array}$ & Quilingiva .... & $\begin{array}{r}\text { Page. } \\
27\end{array}$ \\
\hline & 35 & 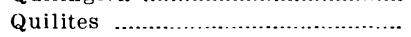 & 71 \\
\hline apaya. & 49 & Quinalumpang ......... & 23 \\
\hline apua .. & 51 & Quinamboy ..... & 83 \\
\hline 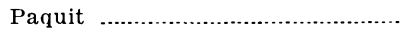 & 86 & Quinampai ................ & 86 \\
\hline Parag-is & 91 & Quinanda ................... & 92 \\
\hline . & 88 & Quinasaicasai... & 42 \\
\hline & 49 & & 83 \\
\hline 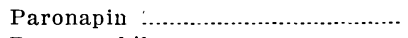 & 24 & Quindayohan ............. & 71 \\
\hline 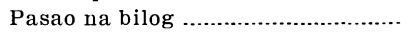 & 26 & Quiroi & 86 \\
\hline a haba ................................... & 26 & Raguindi ........ & 23,33 \\
\hline $0 a$ & 30 & de mora ......... & 92 \\
\hline 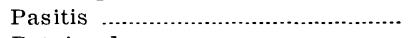 & 64 & $\mathrm{a}$ & 80 \\
\hline $\mathrm{d}$ & 62 & ............ & 70 \\
\hline (1) & 39 & 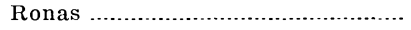 & 87 \\
\hline ing dagat ................................. & 39 & s & 41 \\
\hline . & 49 & 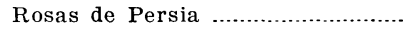 & 86 \\
\hline 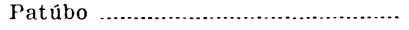 & 82 & 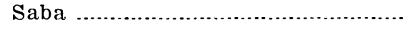 & 83 \\
\hline yang ................................ & 38 & & 72 \\
\hline guit & 60 & & 87 \\
\hline a & 79 & to & 87 \\
\hline lo de San Gregorio .............. & .49 & $\ldots \ldots \ldots . .$. & 73 \\
\hline . & 61 & ........ & 89 \\
\hline catbalogan & 61 & $\ldots \ldots$ & 88 \\
\hline & 2 & ........... & 38 \\
\hline & 30 & .............. & 38 \\
\hline . & 18 & (n)................ & 43 \\
\hline & 7 & ............... & 41 \\
\hline & 6 & .......... & 20 \\
\hline$\ldots \ldots \ldots+\ldots \ldots$ & 6 & .......... & 77 \\
\hline 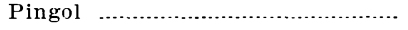 & 8 & & 82 \\
\hline bato & 5 & (1) & 83 \\
\hline$\ldots+\ldots+\ldots \ldots \ldots \ldots$ & & 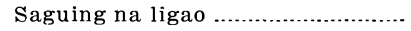 & 83 \\
\hline$\ldots \ldots \ldots \ldots . .$. & 5 & ......... & 61 \\
\hline t angin & & .......... & 47 \\
\hline . & 2 & ............. & 34 \\
\hline ......... & & 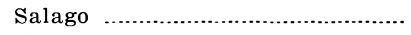 & 74 \\
\hline ........... & 2 & .................... & 49 \\
\hline .......... & & & 92 \\
\hline & & & 32 \\
\hline 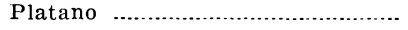 & 8 & ................... & 48 \\
\hline os & 8 & ….......... & 31 \\
\hline . & & ........... & 27 \\
\hline ..................... & 4 & ........... & 27 \\
\hline (n)................... & 3 & .......... & 26 \\
\hline 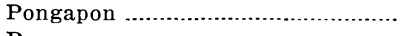 & 9 & (n)...................... & 84 \\
\hline . & 29 & (.)...................... & 82 \\
\hline . & 76 & (......................... & 49 \\
\hline & 46,51 & ............ & 62 \\
\hline 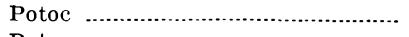 & 9 & ......... & 37 \\
\hline 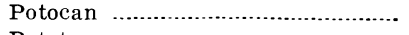 & 64 & 1і & 41 \\
\hline 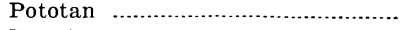 & 44 & 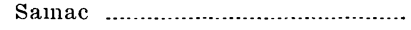 & 78 \\
\hline & 88 & ............ & 72 \\
\hline 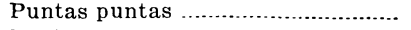 & & .......... & 41 \\
\hline & & .................. & 55 \\
\hline 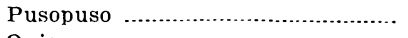 & & (.............. & 55 \\
\hline uiapo & 90 & & 73 \\
\hline 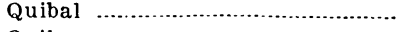 & 40 & Sampac & 15 \\
\hline 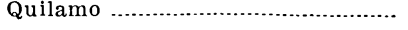 & 47 & Sampaca & 15 \\
\hline
\end{tabular}


Sampaga

Sampaga del monte

Sampagang pougso

Sampalagui

Sampaloc

Sampang

Sincamas

Sandana

Sandoc sandoc

San Francisco

Sangdigquit

Sangilo

Sanque

Sansao

Sansaosansauan .............................

Santa Ana

Santa Maria

Santan

Saog

Sapang .............................................

Sapinit

Sapinsapin

Sapnit

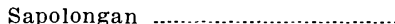

Sasa

Sausanli

Sayican

Siac

Sibog

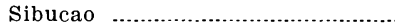

Sigang dagat

Silasila

Silipao

Silisilihan

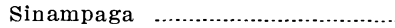

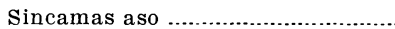

Sintonis

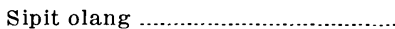

Sirihuelas

Sisiohan

Sitao

Soal

Sobsob

Solanga

Solasi

Solasolasihan

Solinao

Songai

Sonting

Soob cabayao

Sorogsorog

Sorosoro

Sucao

Suganda

Suha

Sulbang

Subsuban

Suliac daga

Sulipa
Page.

58

56

58

41

41

33

40

22,31

50

67,77

56

72

40

17

17

54

56

54

72

41

, 42,43

66,67

41

22

88

34

19,75

78

42

41

55,62

40

32

56,67

53

39

29

87

36

75

39,40

16

55

27

69

70

56

83

41

69

75

75

17

69

29

39

71

53

53
Page.

Suma ........................................ 17

Sumag .................................... 55

Sunting ....................................... 41

Suranga ....................................... 27

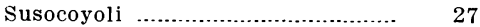

Susoi ............................................ 37

Susong damolag ........................... 16

Susosusoyan ................................. $\quad 37$

Suspiros ........................................ $\quad 70$

Sursur ........................................ 91

Suya .......................................... $\quad 29$

Taal ............................................... 41

Tabaco ............................................ 64

Tabatabacohan ............................ $\quad 55$

Tabayag ........................................ $\quad 49$

Tabigui ...................................... 31

Tabing ............................................ 23

Tablon ........................................... $\quad 78$

Tabobog ......................................... 49

Tabog .......................................... 29

Tabogo ........................................ $\quad 50$

Tabtabocol ...................................... 62

Tabtabocol ti nuang ...................... $\quad 70$

Tac-an ........................................ $\quad 70$

Tacatac ...................................... 81

Taclang onac ........................... $\quad 20$

Taclitan ......................................... $\quad 30$

Tacolin .......................................... 90

Tocor languit ............................... 95

Tacpo ........................................ 54

Tacpong dalaga .......................... 57

Tacpus ......................................... 54

Tacurangan ................................. 23

Tadiang ........................................ 32

Tadiang anunang........................... 53

Tagabas ...................................... 94

Tagabili .......................................... 55

Tagactagac ................................. 67

Tagalhi ......................................... 86

Taganagtagua ........................... 17

Tagapi ....................................... $\quad 36$

Tagarao ......................................... 45

Tagaray ........................................ 62

Tagbac ......................................... 84

Tagbactagbac ........................... 84

Taghilao ....................................... 66

Taghivalas ................................... 16

Tagima ......................................... 51

Taglinao ........................................ 24

Taglocot .......................................... 62

Tagolinao ..................................... 56

Taguilima ................................ 51

Taguima ..................................... 51

Taguipan .................................. 88

Tagung .................................... $\quad 37$

Tahid labuyo ............................ $\quad 80$

Tala .............................................. 64

Talacatac ..................................... 81

T'alactac ............................... 18 
Talailo

Page.

Talamponai

Talamponai na itim

Talanai

Talancao

Talang

Talangtalang

Talaonor

Talatala

Taliantar

Talicnono

Talicoran

Talicot

Talinas

Talingharap

Talinouno

Talisai

Talola

Talolong

Talong

Talong gubat

Talosan

Taloto

Tamahilan

Tamauian

Tambalisa

Tambo

Tambobon

Tamo

Tamocansi

Tamohilan

Tampin banal

Tampohin

Tampoi

Tanag

Tancapan

Tancong

Tangain daga

Tangal

Tangantangan

Tangi

Tangili

Tangisang bayauac

Tanglad

Tanglay maloto

Tangolon

Taointaoin

Tapiasin

Tapit

Tapolanga

Taquing baca

Taquipan

Taquip asin

Taquip cohol

Taquip suso

Tarambolo

Taramhampan

Taratara

Tarocanga

\begin{tabular}{|c|c|c|}
\hline Page. & & Page. \\
\hline 17 & Tartarao & 45 \\
\hline 64 & Tarumpalit ....... & 50 \\
\hline 64 & Tatloug ................ & 32 \\
\hline 33 & 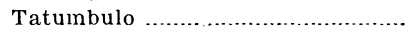 & 64 \\
\hline 56 & 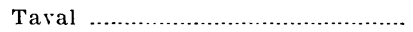 & 82 \\
\hline 57,58 & Tavatava ............ & 76 \\
\hline 73 & Tavatavangsina & 78 \\
\hline 86 & 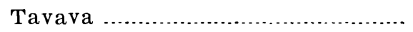 & 75 \\
\hline 64 & Tavbibung. & 64 \\
\hline 54 & Tayom ............. & 37 \\
\hline 61 & Tayomtayom ... & 37,60 \\
\hline 85 & Tayomtayoman ... & 37 \\
\hline 79 & Tayoto ............................ & 61 \\
\hline 33 & Tayung $\ldots .$. & 37 \\
\hline 70 & Teca ........... & 67 \\
\hline 35 & Ternate ... & 67,83 \\
\hline 44 & Tiauanac. & 93 \\
\hline 88 & Tiaun ........... & 81 \\
\hline 80 & Tibatib ............................ & 90,94 \\
\hline 64 & Tibig ............................ & 79 \\
\hline 64 & Tibig na lalaqui ..... & 79 \\
\hline 25 & Ticas ......................... & 84 \\
\hline 24 & Ticas ticas ................. & 84 \\
\hline 84 & Ticla & 67 \\
\hline 20 & Tigasall ............... & 44 \\
\hline 40 & Tigbi ............. & 91 \\
\hline 93 & Tighiman ..... & 41 \\
\hline 86 & Tililes ................. & 71 \\
\hline 84 & Timbagan & 72 \\
\hline 84 & Timbangantimban & 72 \\
\hline 84 & Timsim .................... & 91 \\
\hline 90 & Tinaingui $\ldots . .$. & 35 \\
\hline 83 & Tinalong ......... & 83 \\
\hline 45 & Tinatinaan ... & 76 \\
\hline 24 & Tindalo ............... & 41 \\
\hline 27 & Tingang baguis .. & 57 \\
\hline 62 & Tingatinga $\ldots . . .$. & 53 \\
\hline 27 & Tingloi ................ & 66 \\
\hline 43 & Tinisas .................. & 56 \\
\hline 64,78 & Tinitrigo ............ & 91 \\
\hline 92 & Tintatinta ........ & 55 \\
\hline 22 & Tintatintahan . & 76 \\
\hline 79 & Tinumbaga ....... & 83 \\
\hline 92 & Tipolo ................... & 80 \\
\hline 68 & Tiquio ................. & 90 \\
\hline 45 & Tiquistiquis ...... & 34,84 \\
\hline 72 & Tirbatib ............... & 90 \\
\hline 62 & Titio ........ & 66,90 \\
\hline 78 & Toar ...................... & 59 \\
\hline 23 & Toctoc calo.......... & 58 \\
\hline 23 & Tomates .............. & 63 \\
\hline 88 & Toncod Obispo & 87 \\
\hline 78 & Tondoc .. & 83 \\
\hline 50 & Tongo $\ldots$. & 86 \\
\hline 50 & Tongog .... & 43 \\
\hline 64 & 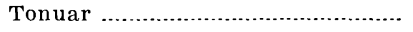 & 86 \\
\hline 64 & 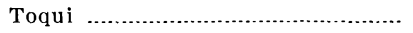 & 87 \\
\hline 31,64 & 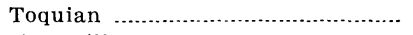 & 21 \\
\hline 23 & Torrecilla & 66 \\
\hline
\end{tabular}




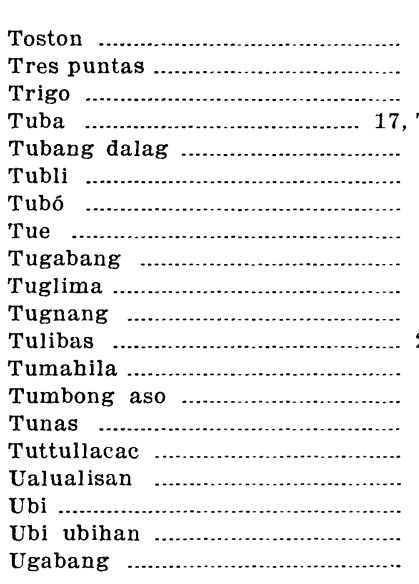

Page.

Page.

78 Varas hari

36

91 Varas ni José................... 87

Trigo

$17,76,77$

Vilos

67 Vocabul .......................................... 23

37 Yabag ........................................... 40

92 Yacal ............................................. 22

66 Yambo ....................................... 45

41 Yampoi .................................... 45

51 Yantoc .......................................... 88

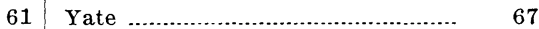

28,48 Yates .......................................... 16

84 Yayo ............................................ 27

54 Yerba buena ............................... 70

17 Yerva mora .................................. 92

64 Yovas ........................................ 67

23 Zabache ....................................... 39

86 Zapote negro ................................. 58

87 Zarzaparrilla 


\section{INDEX TO LATIN NAMES. ${ }^{1}$}

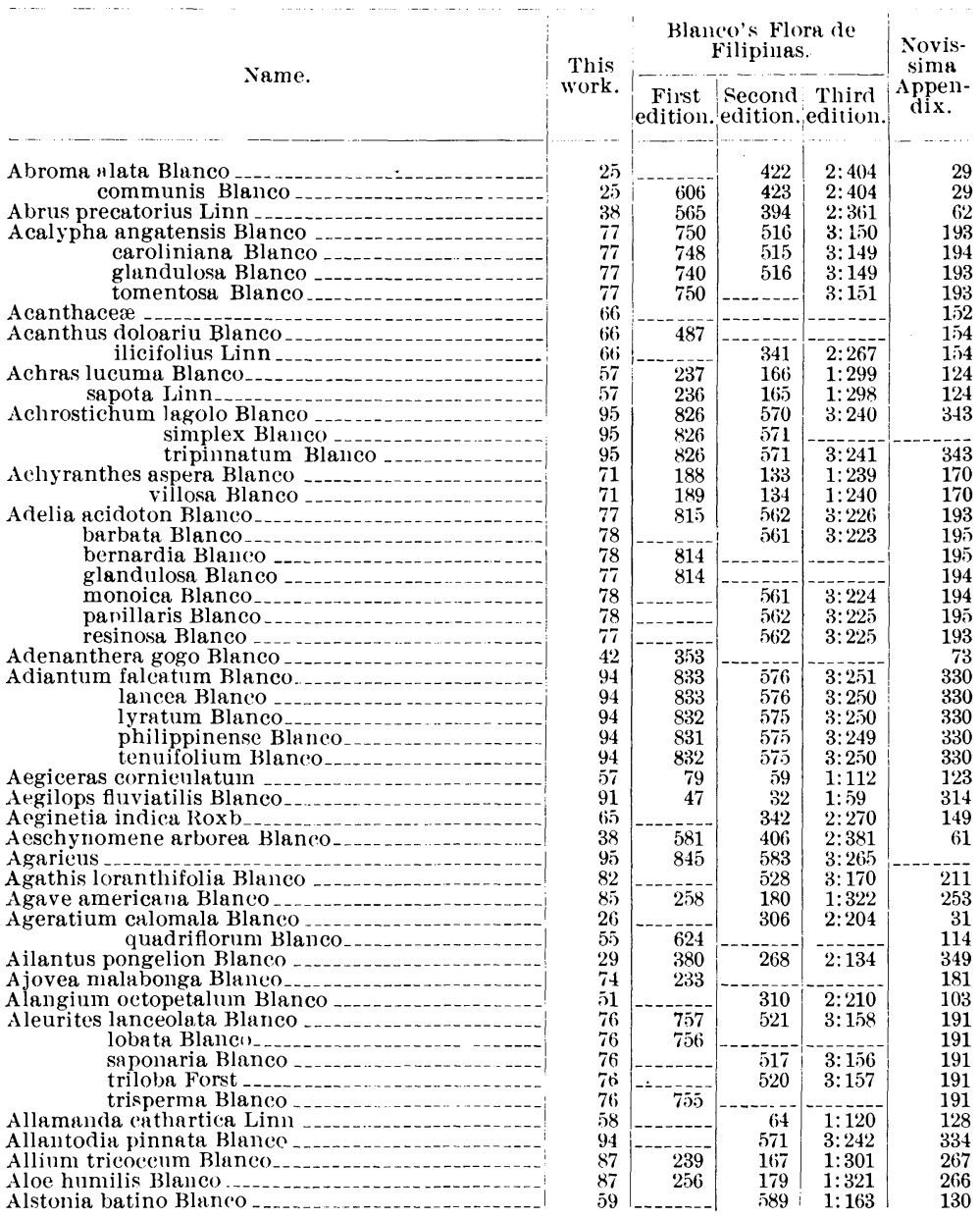

1 This index includes only the names used by Blanco, and family names according to the Bentham and Hooker system of classification. The numbers in the first eolumn refer to the present paper: in the second, to the first edition of Blanco's Flora de Filipinas: in the third, to the second edition: in the fourth, to the third edition; and in the fifth, to the Novissima Appendix. 
This work.

Althaea rosea Cav sinensis Blaneo

Amarantacex

Amaranthus cruentus $\mathrm{L}$

mangostamus Blanco.

Amaryllidacea

Amaryllis atamasco Blanco

Amerim num mimosella Blanco

Ammania debilis Ait monoflora Blaneo ramosior Blanco

Ammi glaucifolium Blanco

Amomum eehinatum Blanco zerumbet Linn zingiber Linn

Amorpha glandulosa Blanco

Ampelidacexe pedalis Blanco

Anacardiacese

Anasser laniti Blaneo

Anavinga fuliginosa Blaneo

Andromeda japonica Blaneo

Andropogon aciculatus Retz contortus Linn
nardus Blanco ramosus Blanco schoengnthus Blaneo-

Anethum foeniculum Linn .

Anonacere

Anona murienta Linn reticulata Linn squamosa Linn

Anthemis cotula Blaneo

Anthistiria gigantea $\mathrm{Cav}$

Antholyza meriana Blanco

Antidesma alexiteria Blaneo spicata Blanco

Antirrhinum comintanum Blanco molle Blanco

Apocynaceæ

Apocsnum mucronatum Blanco

A poretica gemella Blanco penieillata Blanco ternata Blanco

Aquilaria pentrandra Blanco

Aquilicia sambucina Blaneo

A racer

Arachis hypogaea Linn

A raliacese

Aralia octophylla Blanco pendula Blanco.

pipinnata Blanco

Areca catechu Linn tripinnata Blanco catechu humilis Blanco

Arethusa glutinosa Blanco

rgemone mexican a

Argophyllum pinnatum Blanco

Aristolochiacere

A ristolochia indiea Blanco sericea Blaneo subsagittata Blaneo

Artemesia viridis Blanco vulgaris Linn

Artocarpus camansi Blanco incisa $\mathrm{L}$. $\mathrm{f}$ integrifolia L. f lamellosa Blanco maxima Blanco odoratissima Blanco. ovata Blanco rima Blanco
Blanco's Flora de Filipinas.

Novissima First Second Third Appenedition. edition. edition. dix.

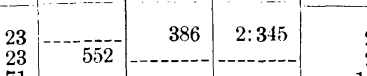

7

7

7

8

8

4

47

47

84

83

37

19

35

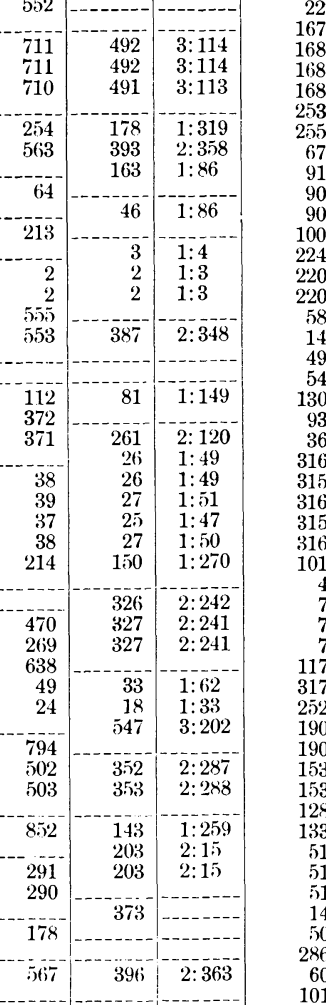

22

222

223

641

454

186

282

282

283

625

740

668

667

669

671

666

671 
Name.

Arum decurrens Blanco

divaricatum $\mathrm{L}$

grandifolium Blanco

Arundo tecta Blanco

Asclepiadacece

Asclepias carmosa Blanco daemia Blaneo

giguntea Willd . peregrina Blaneo. siriaca Blanco

Atragene zerlanica Blanco

Averrhoa bilimbi Limn corumbola Lin ventaudra Bla

Avicennia nitida Blaneo tomentosa $\mathrm{R} . \overline{\mathrm{Br}}$

Azaola betis Blanco

Azima nova Blanco -

Baccharis indica Linn. ivefolia Blanco

Balingayum decumbens Blanco

Bambus arundo Blanco diffusa Blanco levis Blanco

lima Blanco lumampao Blanco mitis Blaneo

mollogyna Blanco pungens Blanco textoria Blanco

Banara brevifolia Blanco racemosa Blanco

Barreliera cristata Blanco prionitis Blanco

Barringtonia racemosa Blume speciosa Forst stravidium Blanco

Basella lucida Limn rubra

Bassovia svlvatica Blanco -

Batis hermaphrodita Blanco.

Bauhinia binata Blanco castrata Blanco. grandiflora Blanco purpurea Blanco scandens Blanco tomentosa Blanco

Begoniaceæ

Begonia capensis Blanco

Bergera compressa Blanco inodora Blanco -termuta Blanco

Bergia serrata Blanco

Bidens bipinnata Linn

Bignoniacer.

Bignonia quadripinnata Blanco spathacea Linn

Biophytum sensitivum I

Bixaces

Bixa orellana Linn

Bladhia japonica Blancc

Blechnum colubrinum Blanco -

Boerhaavia diffusa Linn.

Bombax ceiba Iinn pelltandrum Linn.

Boraginacex.

Borago africana Blanco indica Liun

Boswellia integra Blanco-
obliqua Blanco

$21896-8$
Bluneo's Flora de Filipinas.

Novissima This work. First / Second Tlird Appen dition. edition. edition.

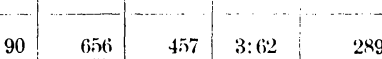

\begin{tabular}{ll|l|l|l}
90 & 657 & $45 \times$ & $3: 62$ & $29 \%$
\end{tabular}

\begin{tabular}{r|r|r|r|r}
90 & -0 & 458 & $3: 63$ & 294 \\
93 & 48 & 33 & $1: 60$ & 321
\end{tabular}

59 -

\begin{tabular}{ll|l|l|l}
60 & 208 & 147 & $1: 263$ & 135 \\
& 208 & 146 & $1: 263$ & 133
\end{tabular}

60

15 
Name

Brabejum caliculatum Blanco concatenutum Blanco lucidum Blanco

pinnatum Blanco

Brassica orientalis Blanco.

Bromelince

Bromelia anawas Linn

Broussonetia luzonensis Blaneo tinctoria Blaneo

Bruguiera nemorosa Blanen.

Bryophyllum germinans Blanco serratum Blanco triangulare Blanco

Bucida comintana Blanco

Buddleia virgata Blanco

Buginvillea racemosa Blanco

Burseracexe

Bursaria inermis Blanco

Caealia sarracenica Blanco

Cactreese sonchifolis

Cactus opuntia Blanco pitajaya B]anco

Caesalpinia ignota Blanco sappan Linn -

Cajanus bicolor $10 \mathrm{C}$ torquata Blanco quinquepetalus Blaneo volubilis Blanco

Caladium digitatum Blanco esculentum Blanco

Calamus gracilis Blanco maximus Blanco mollis Blanco -

usitatus Blanco

Calius lacteseens Blaneo

Calla badian Blanco

gaby Blanco

maxima Blanco

polyphylla Blanco

Callicarpa americana Blanco

Calophyllum apetallum Blanco inophyllum Linn

Calyptranthes jambolana Willd makul Blanco -. ramiflora Blanco zuzugium Blaneo

Calytriplex obovata $R$. et $P$

Cambogia binucao Blanco. crassifolia Blanco. vinulosa Blanco

Camellia sasar:qua Blanco

Campanulacere

Canarium album Blanco commune Blanco pimela Blanco

Canavalia ensiformis Blanco gladiata DC.

Canna indica Linn

Cansiera grossularioides Blaneo pentandra Blanco. rheedii Blanco -

Canthium horridumi monoflorum Blance paueiflorum Blanco pedunculare Cav

Capparidacere

Capparis baducea Blanco mariana Jaca micracantha Blaneo nemorosa Blanco
Blanco's Flora de Filipinas.

This work

First second Third Appenedition edition edition dix.

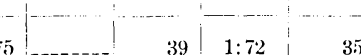

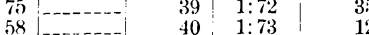

\begin{tabular}{l|l|l|l|l}
58 & $-\ldots$ & 40 & $1: 74$ & 129
\end{tabular}

\begin{tabular}{l|l|l|l|l}
58 & 40 & $1: 74$ & 129
\end{tabular}

\begin{tabular}{l|l|l|l|r}
17 & 519 & 361 & $2: 303$ & 10 \\
\hline 66 & & & & \\
\hline
\end{tabular}

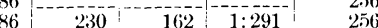

\begin{tabular}{l|l|l|l|l}
78 & -230 & 162 & $1: 291$ & 250
\end{tabular}

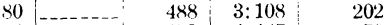

\begin{tabular}{ll|l|l|l}
44 & 275 & $2: 147$ & 79
\end{tabular}

\begin{tabular}{l|l|l|l}
43 & 220 & $2: 47$ & 78
\end{tabular}

\begin{tabular}{ll|l|l}
43 & 220 & $2: 48$ & 78
\end{tabular}

\begin{tabular}{l|l|l|l}
43 & 221 & $2: 48$ & 78
\end{tabular}

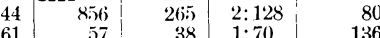

\begin{tabular}{l|r|r|r|r}
70 & 307 & 214 & $2: 36$ & 167
\end{tabular}

29 -

$18 \mid-124$

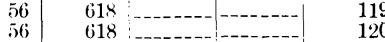

50 -

\begin{tabular}{l|l|l|l|l}
50 & 414 & 288 & $2: 171$ & 99
\end{tabular}

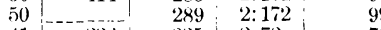

\begin{tabular}{l|l|l|l|l}
41 & 336 & 235 & $2: 72$ & 70
\end{tabular}

\begin{tabular}{l|l|l|l|l|}
41 & 335 & 234 & $2: 72$ & 69
\end{tabular}

336 -

\begin{tabular}{l|l|l|l|l|}
40 & - & 416 & $2: 396$ & 60 \\
38 & - & 417 & $2: 397$ & 61
\end{tabular}

40

\begin{tabular}{ll|l|l|l}
90 & 459 & $3: 64$ & 294
\end{tabular}

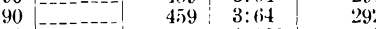

\begin{tabular}{l|l|l|l|l}
88 & 267 & 186 & $1: 332$ & 275
\end{tabular}

\begin{tabular}{l|l|l|l|l}
88 & 266 & 185 & $1: 331$ & 276
\end{tabular}

\begin{tabular}{l|l|l|l|l|}
88 & 264 & 184 & $1: 329$ & 275
\end{tabular}

\begin{tabular}{l|l|l|l|l}
88 & 265 & 185 & $1: 330$ & 275
\end{tabular}

\begin{tabular}{l|r|r|l|l}
78 & 698 & 543 & $3: 103$ & 198 \\
90 & $658-609$ & 459 & $3: 6.4$ & 293
\end{tabular}

$90 \quad 658$ (5)

$90 \quad 659$

\begin{tabular}{l|l|l|l|l}
67 & 517 & 360 & $2: 300$ & 158
\end{tabular}

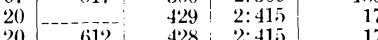

1

46 419 46

$46 \quad 420$ - 46

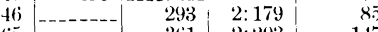

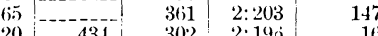

\begin{tabular}{|l|l|l|l|}
431 & 302 & $2: 19 \dot{0}$ & 16
\end{tabular}

\begin{tabular}{l|l|l|l|l}
20 & - & 304 & $2: 198$ & 16 \\
20 & 435 & 303 & $2: 197$ & 16
\end{tabular}

\begin{tabular}{l|l|l|l|l}
21 & 530 & 371 & $2: 322$ & 19
\end{tabular}

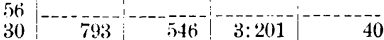

$30 \div 791 / 0.51 \%$

\begin{tabular}{l|l|l|l|l}
30 & -19 & 545 & $3: 201$ & 40 \\
39 & & 404 & $2: 578$ & 64
\end{tabular}

39 - 403 2:376

\begin{tabular}{r|r|r|l|l}
84 & 6 & 5 & $1: 8$ & 229 \\
76 & 73 & 53 & $1: 99$ & 190
\end{tabular}

\begin{tabular}{l|l|l|l|l}
76 & 73 & 53 & $1: 98$ & 190
\end{tabular}

\begin{tabular}{l|l|l|l|l}
76 & 73 & 52 & $1: 98$ & 190
\end{tabular}

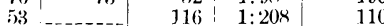

53 i 160 - 110

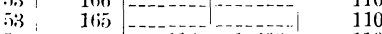

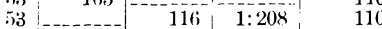

17 : 10

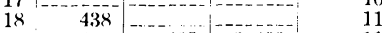

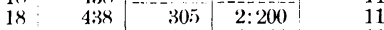

18 305 $2: 200 \quad 11$

18

18

438 
Name.

Capparis odorata Blaneo

Caprifoliacer

Capsicum minimum Roxb

Capura pimnata Blanco

purpurata Blanco.

Cardamine glandulosa Blanco

impatiens Blanco

Cardiospermum halicacabuu Limu

Carex glomerata Blanco

tuberosa Blanco

Carica hermaphrodita Blanco papaya L.

Carmonea heterophylla Cav

Carthamus tinctorius Linn

Caryophyllacere

Caryota onusta Blanco.

palindan Blanco

tremula Blanco

urens Blanco

Casearia fuliginosa Blanco

Cassia alata Limn

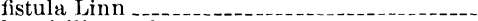

longisiliqua Blanco

mimosoides Linn

occidentalis I

sulcata Blanco.

tora Limn

Casuarina equisetifolia Forst

Cassuvium reniforme Blanco

Cassy tha filiformis I

Cedrela odorata Blanco

Cedrota guinanensis Blanco

Celastracee

Cclosia argentea Linm

baccatr Ret $\%$

bicolor Blanco

coccinea Blunco

cristata Linn

glauca Blaneo

lanata Blaneo

Celtis lima Blanco

philippinensis Blanco

Cench rus hexatlorus Blaneo

Cephaclis expalegeea Blaneo

Cerbera manghas Blume thevetia Linn

Chailletiacere

Chenopodiacea

Chenopodium ambrosioides Linn

Chironia eapsularis Blanco lanosantlera Blanco

Chloranthacese

Chloranthus inconspicuus Blaneo

Cicca acidissima Blanco decandra Blanco

pentandra Blaneo

Cissampelos pareira Linn

Cissus acida Roxb.

alata Blanco
arborea Blanco--

frutescens Blanco

latifolia Vahl

pedata Blanco

quadrungularis Linn

rubescens Blanco

simplex Blanco -

vesicatoria Blanco

Citrus uurantium

decumana Linn.
This

Blanco's Flora de Filipinas.

work.

First Seeond Third edition. erition. odition. sima Appendix.

\begin{tabular}{|c|c|c|c|}
\hline 18 & 439 & 305 & $2: 201$ \\
\hline 64 & 133 & $9 \overline{5}$ & $1: 174$ \\
\hline 35 & 264 & & $-{ }_{1}, \cdots$ \\
\hline
\end{tabular}

5

1

88

88

88

48

41

41

41

4

36

74

8

31

70

32

71

71

7

7

71

47

78

78
91

9

5

58
31

7

T.

63

63

76

76

1

33

33

27

33

33
33

33
33
33

28

28
(1) 1

31.

312

35

803

803

616

741

744

740

339

339

338

340

$33 \mathrm{x}$

337

661

322

321

184

....-

$19^{\circ}$

193

191

191

191

192

197

197

36

i.

125

......

200

102

-.....-

700

700
701

701

815

69

70

71

72

72

609

608

\section{1}

145

(i)

9

9

308

306

95

95
138

138

120

14

280

280
280

279

93

70

70

70

71

70

70

207

54

182

206

45

45

167

46

167

167

168

167

167

168

169

91

197

197

313

105

129

129

45

171

171

141

141

177

177

188

188

189

8

49

49

34

34

49

50

49

49

49

49 
Name.

Citrus mitis Blanco -...

notissima Blanco

papillaris Blaneo

reticulata Blanco

torosa Blanco

Cleome alliacea Blanco
alliodor Blanco

gigantea Blanco

pentaphylla Blaneo

viscosa Limn

Clerodendron capsulare Blanco

fortunatum Blaneo

clethra alnifolia Blanco

Clitorea ternatea $\mathrm{L}$

Clutia stipularis Blanco

Cnestis corniculata Blanco

diffusa Blanco

erecta Blanco

glabra Blanco

polyphylla Bian trifolia Blanco -

volubilis Blanco

Cocos mammilaris Blanco nucifera Linn

Codamba blancoi Azaola dichotoma Blanco

Coenopteris quadripinnata Blanco

Coffea arabica Linn volubilis Blanco

Coix lachryma Linn

Coldenia procumbens Linm

Coleus grandifolius Blaneo pumilus Blanco

suganda Blaneo_

Columbia anilao Blanco--

Combretaceas

serratifolia Blanco

Combretum distillatorium Blanco laxum Blanco.

Commelinacea

Commelina polygama Blanco

Commersonia echinata Blanco

Comocladia serrata Blanco

Compositax

Conifera.

Conferva littoralis Blanco

Connaracea setosa Blaneo

Connarus foeteris Blanco santaloides Blanco

Convolvulacee

Convolı ulus batatas Iinn -

cathurticus Blanco

colubrinus Blanen

dentatus Blaneo

distillatorius Blau

hederaceus Blanco

longiflorus Spreng

maximus Blanco

muricatus Blanco.

nil Linn

paniculatus Iinn

pes-caprae Linn -

pes-tigridis Linn

reniformis Roxb

repens willd

valerianoides Blanco

Conyza balsamifera ('appa Ham

dentata Blanco

erosa Blanco
This

work.

Blaneo's Flora de Filipinas.

First Second Third Appenedition.edition. edition. dix.

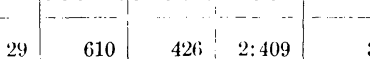

r

2
2
2
1
1
1
1
17

$$
68
$$

(4)

is

18

17

\section{6}

\section{7}

36

37
37
36
36
36

36
36
88

88

88
$6 \mathrm{~L}$
61

61
94

94

54
54

9

91

62

69

69

2

4

44

44
87

8

25

54

82

95
97
36

36
28
28

62

(ii)

63

$$
\text { tis }
$$

(i)

(i)

63

(i)

\section{2}

ti:

6

\section{3}

6.

$$
\begin{aligned}
& 5.5 \\
& 5.5 \\
& 55 \\
& 5.5
\end{aligned}
$$

610

610

609
522

522

523

522

509

$50 \mathrm{x}$

590

818

$3 \times 6$

396

287

387

38

$$
722
$$

510

510
833

$15 i$

157

$6 \times 8$

74

482

482

483

6.54

426

2: 406

425 2: 409

$425 \div 2: 408$

$425,2: 407$

363 ; $2: 307$

$364 \quad 2: 307$

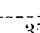

35) $\quad 2: 292$

345 2:291

259 $2: 117$

\begin{tabular}{l|l}
412 & $2: 391$
\end{tabular}

$56+3: 229$

$270 \quad 2: 138$

27

$2: 138$

270

270

$2: 137$

2: 136

499 3:123

495 3:123

$591 \quad 2: 293$

35.) $2: 293$

576 $3: 252$

110

111

$47 x$

$1: 198$

$1: 200$

3: 92

$1: 10$;

336

336

337

426

$2: 258$

$2: 259$

$2: 259$
$2: 412$

2: 412

$42 \%$

295

\begin{tabular}{l|l|r|r|}
-206 & $2: 206 \mid$
\end{tabular}

\begin{tabular}{|c|c|c|c|}
-25 & 18 & $1: 34$ & 269
\end{tabular}

\begin{tabular}{l|r|r|r}
-160 & $1: 287$ & 29
\end{tabular}

\begin{tabular}{r|r|r|r|}
30 & -17 & 13
\end{tabular}

211

\begin{tabular}{l|l|l|l}
843 & 582 & $3: 262$ & $-\cdots-$ \\
844 & 583 & $3: 264$ & -
\end{tabular}

\begin{tabular}{ll|l}
525 & 56 \\
\hdashline & & 36
\end{tabular}

(- 366 2:314

\begin{tabular}{|l|l|l|l|} 
& 93 & 68 & 139
\end{tabular}

\begin{tabular}{|c|c|c|c}
-03 & 67 & $1: 125$ & 143
\end{tabular}

\begin{tabular}{|c|c|c|}
94 & - & 141
\end{tabular}

\begin{tabular}{|c|c|c|c|}
\hline 89 & 60 & $1: 123$ & 142
\end{tabular}

\begin{tabular}{|l|l|l|l}
95 & 70 & $1: 130$ & 141 \\
90 & 66 & $1: 124$ & 142 \\
\hline
\end{tabular}

\begin{tabular}{|c|c|c|c} 
& 69 & $1: 130$ & 141
\end{tabular}

\begin{tabular}{l|l|l|l}
91 & 67 & $1: 127$ & 141 \\
92 & 68 & $1: 127$ & 139
\end{tabular}

\begin{tabular}{l|l|l|l}
92 & 68 & $1: 128 ;$ & 140
\end{tabular}

\begin{tabular}{ll|l|l}
96 & 70 & $1: 131$ & 142
\end{tabular}

\begin{tabular}{ll|l|l}
88 & 65 & $1: 123$ & 140
\end{tabular}

\begin{tabular}{ll|l|l}
97 & 71 & $1: 133$ & 141
\end{tabular}

$\begin{array}{lllll}91 & 67 & 1: 126 & 142\end{array}$

\begin{tabular}{ll|l|l}
92 & tis & $1: 128$ & 142
\end{tabular}

90

628 438

\begin{tabular}{l|l|l|l}
\hline $629^{-}$ & 438 & $3: 18$ & 116
\end{tabular}

629 - $12:-117$

115 


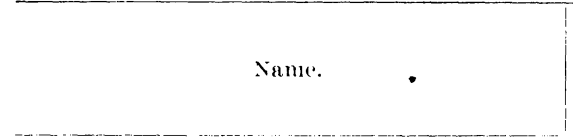

\begin{tabular}{|c|c|c} 
This & $\begin{array}{c}\text { Blaneo's Flora do } \\
\text { Filipinas. }\end{array}$ & $\begin{array}{c}\text { Novis- } \\
\text { sima } \\
\text { work. }\end{array}$ \\
$\begin{array}{c}\text { First second Third } \\
\text { Appen- } \\
\text { edition. edition. }\end{array}$
\end{tabular}

Conyza gouana Blanco.

Cookin anisodora Blanco -

anisum-olens Blanco

Wrmpi Blanco

Corchorus acutangulus Lim

aestuans Blanco

('apsularis Linn -

catharticus Blanco

olitorius Linn

Cordia banulo Blanco....

dichotoma Blanco.

ignota Blanco

olitoria Blanco -

sebestina Blanco

Coreopsis grucilis Blanco

Cornacere.

Coronilla enerus Blanco

Corypha minor Blanco umbraculifera Linin

Costus luteus Blanco nigricans Blanco

Cotula quinqueloba Blaneo.

Cotyledon lanceolatum Blanco paniculata Blanco

Crassulacese serrata Blanco

Crataeva octandra Blanco religiosa Forst -

Crescentia trifolia Blanco

Crinum asiaticum Blanco

giganteum Blanco

Crotalaria linifolia Linn. f pallida Blanco

pumila Blanco quinquifolia Limn

Croton drupaceum Blanco graudifolium Blanco glandulosum Blanco

Jiceiferum Blaneo

muricatum Blanco.

Crueiferie

variegatus $\mathrm{I}$.

Crudia spicata Blanco

Cueumis acutangulus Linn luzonieus Blanco
melo Linn

cueurbitacere

Cucurbita lagenaria-oblonga Blanco

lagenaria-villosa Blanco.

pepo-aspera Blanco

sulcata Blanco

Cupania spinosa Blanco

Cupuliferre.

Cureuma longa Linn

Cyeadacere -

Cyeas circinalis Linn

Cylista piscatoria Blanco

Cynanchum hirtum Blanco tenellum Blanco

viminale Blanco

Cynomorium philippinense Blanco

Cyperaceese

Cyperus difformis puniculatus Blanco

rotuudus Blanco

Cypripedium bulbosum Blanco

Cyrtandra a ristata Blanco

glaberrima 31 anco

personata Blanco

quinquestila Blanco

Cytisus cajan Linn

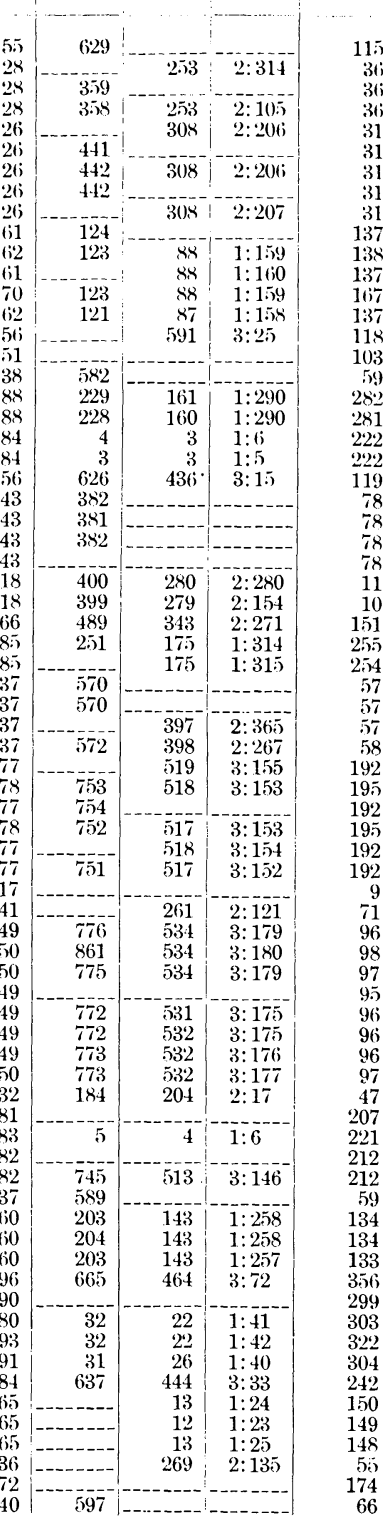




\begin{tabular}{|c|c|c|c|c|c|}
\hline \multirow{2}{*}{ Nanne. } & \multirow{2}{*}{$\begin{array}{l}\text { This } \\
\text { work. }\end{array}$} & \multicolumn{3}{|c|}{$\begin{array}{c}\text { Blancoss flora de } \\
\text { Filipinas. }\end{array}$} & \multirow{2}{*}{$\begin{array}{l}\text { Novis- } \\
\text { sima } \\
\text { Appen- } \\
\text { dix. }\end{array}$} \\
\hline & & $\begin{array}{l}\text { First } \\
\text { edition. }\end{array}$ & $\begin{array}{l}\text { ond } \\
\text { tion }\end{array}$ & $\begin{array}{l}\text { Third } \\
\text { edition. }\end{array}$ & \\
\hline Cytisus quinquepetalus Blanco _. & 38 & 598 & & & \\
\hline volubilis Blanco & 40 & 599 & & & 66 \\
\hline ais laurifolia Blanco & 74 & 375 & 263 & $2: 125$ & 183 \\
\hline Dalea alopecuroides Blanco - & 37 & & 389 & $2 ; 351$ & 58 \\
\hline Dapne aquilaria Blanco ............ & 74 & 310 & 216 & $2: 39$ & 182 \\
\hline foetida Blanco & 74 & 308 & 214 & $2: 37$ & 182 \\
\hline indica Linn & 74 & 309 & 215 & $2: 38$ & 182 \\
\hline Datura fastuosa I & 64 & 100 & 73 & $1: 136$ & 145 \\
\hline metel $\mathrm{B}$ & 64 & 98 & 72 & $1: 136$ & 145 \\
\hline Daucus anisodor & 50 & & 150 & $1: 269$ & 101 \\
\hline oides $\mathrm{R}$. Br....... & 71 & & 135 & $1: 244$ & 167 \\
\hline Delima aspera Blanco & 15 & 429 & 299 & $2: 191$ & \\
\hline Dendrobium ter & 84 & 638 & & & 242 \\
\hline to & 84 & & 444 & $3: 34$ & 242 \\
\hline Dentella repen & 52 & 146 & 103 & $1: 190$ & 106 \\
\hline Desmodium di & 38 & & 408 & $2: 384$ & 62 \\
\hline ga & 38 & & 408 & $2: 384$ & 62 \\
\hline $\mathrm{p} \varepsilon$ & 38 & & 408 & $2: 386$ & 62 \\
\hline sf & 38 & & 408 & $2: 385$ & 61 \\
\hline Dianthera amer & 67 & 16 & 12 & $1: 22$ & 155 \\
\hline cilia & $6 \overline{7}$ & & 12 & $1: 22$ & 155 \\
\hline sut & 67 & 16 & 11 & $1: 22$ & $15 \%$ \\
\hline Dicerma pulcl & 38 & & 407 & $2: 383$ & 61 \\
\hline Diceros stoloniferus Blance & 64 & 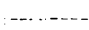 & 349 & $2: 282$ & 147 \\
\hline cee $\infty$ & 15 & & $-\ldots$ & $-\ldots$ & \\
\hline Dillenia is & 15 & 427 & & & \\
\hline & 15 & & 329 & $2: 244$ & \\
\hline Diosco & 86 & & & & 258 \\
\hline Dioscorea aly & 86 & 799 & 550 & $3: 267$ & 259 \\
\hline bol & 39 & 800 & 551 & 208 & 64 \\
\hline Bla & 86 & 797 & 550 & $3: 206$ & 258 \\
\hline $\mathrm{pa}$ & 86 & 801 & 552 & 210 & 260 \\
\hline la 1 & 86 & 802 & $5 \overline{5} 2$ & $3: 210$ & 259 \\
\hline & 87 & & 5.1 & $3: 209$ & 260 \\
\hline & 86 & 799 & 51 & $3: 208$ & 260 \\
\hline ti & 87 & 800 & & & 260 \\
\hline Diosma serr & 32 & 168 & 119 & & \\
\hline Diospyros bifl & 57 & 303 & 210 & $2: 28$ & 126 \\
\hline & 58 & & 209 & $2: 2$ & 127 \\
\hline $\mathrm{kal}$ & $5 \pi, 58$ & 302 & 211 & $2: 29$ & 126,127 \\
\hline & 57 & 210 & & $2: 29$ & 126 \\
\hline & 57 & 303 & & & 126 \\
\hline & 58 & & 211 & $2: 30$ & 127 \\
\hline $\mathrm{p}$ & $5 \overline{7}$ & 304 & 211 & $2: 31$ & 126 \\
\hline Dipterocarp & 21 & & & & 20 \\
\hline Dipterocarpus g & 21 & & 31.4 & $2: 218$ & 20 \\
\hline & 22 & .... & 313 & $21 \overline{5}$ & 21 \\
\hline mal & 22 & & 312 & $2: 214$ & 21 \\
\hline & 22 & $\ldots$ & 313 & 16 & 21 \\
\hline & 21 & $-\cdots$ & 313 & $2: 215$ & 20 \\
\hline & 22 & & 312 & 14 & \\
\hline & 22 & ..- & 311 & 12 & 21 \\
\hline & 22 & -.... & 312 & 13 & \\
\hline & 22 & $-\ldots$ & 310 & 12 & 20 \\
\hline & 21 & & 314 & $2: 217$ & 20 \\
\hline Dodon & 35 & 312 & 217 & $2: 40$ & \\
\hline Dolichos aci & 39 & 578 & & & 64 \\
\hline & 40 & & 401 & $2: 373$ & 6.5 \\
\hline ens & 39 & 577 & & & 64 \\
\hline repe & 39 & 577 & 402 & $2: 373$ & 65 \\
\hline sesq & 40 & & 402 & $2: 375$ & (65) \\
\hline $\sin 0$ & 40 & 575 & & & \\
\hline & 40 & 576 & 402 & & \\
\hline trilo & 39 & & 403 & $2: 375$ & 65 \\
\hline Dombeya bisc & 25 & & 244 & $2: 90$ & \\
\hline & 25 & 349 & & & \\
\hline Dorstenia p & 80 & 692 & 481 & $3: 98$ & 204 \\
\hline aena termin & 87 & 263 & 183 & $1: 328$ & 26.5 \\
\hline Droseraceæ & 43 & & & & 78 \\
\hline Drosera hexagynia Blanco & 43 & 226 & 159 & $1: 2 \times 6$ & \\
\hline $\begin{array}{l}\text { Ebenacere } \\
\text { Echites caudata Blanco }\end{array}$ & $\begin{array}{l}57 \\
59\end{array}$ & 106 & 77 & $1: 143$ & $\begin{array}{l}126 \\
131\end{array}$ \\
\hline
\end{tabular}


Blanco's Flora de Filipinas.

This

Echites procumbens Blanco repens Blanco seholaris Linn

trifida Blanco spiralis Blanco

Ehretia beurreria Blanco virgata Blaneo

Elaengnacea

Elacaguus a ungtifolia Blaneo

Elıeocarpus integrifolius Blanco. sylvestris Blanco

Elatineace

Eleana seminuda Blanco.

Elephantopus dubius Blaneo seaber Linn
serratus Blanco

Elytraria amara Blaneo

Emelia sonelifolia DC-

Enrila dichotoma Blanco.

Entada pursaetha DC

Eperua decandra Blaneo falcata Blanco.

rhomboidea Blaneo.

Epidendrum equitans Blanco lineare Blaneo.

vanilla Blanco

Ericacea

Erotium lanigerum Blunco

Erythrina cafira Blaneo carnea Blanco picta Blanco

Eugenia bauanguica Blanco cauliflora Blanco glandulosa Blanco.

jumbos Blanco

lobas Blanco

malaceensis Blanco

mananquil Blanco

montana Blanco

Euputorium ayapana Vent

Euphorbiacea -
Euphorbia cupitata Lam dulcis Blanco

parannaquensis Blanco .

pentagona Blanco tirucalli L

Euplooria cubili Blanco. didyma Blanco litehi Blanco nephelium Blanco annularis Blanco malaanonan Blanco

Evodia bintoco Blanco triphylla I)C

Evolvulus linifolius Linn

Exacum albens Blanco

Excaecaria agallocha Blanco laevis Blanco sicea Blaneo

Exostemma philippicum Blanco

Fagara deeandra Blanco octandra Blanco piperita Blaneo. pterota Blanco.

Fugraca seholaris Blanco

Fygus philippensis Blanco Feronia ternata Blanco.

Ficoidere

Ficus argentea Blanco. aspera Blanco aspera nota Blanco

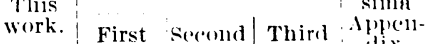
edition. edition. edition, dix.

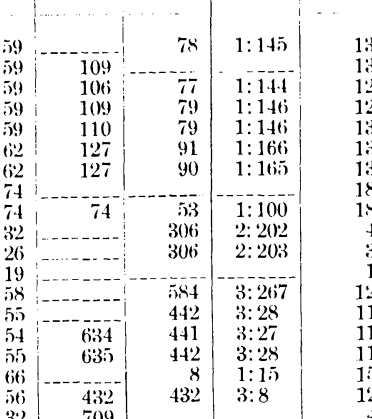

1:3)

130

13

138

18.3

18.3

31

15

109

114

114

114

152

48

73

72

72

236

$23 x$

248

121

356

63

63

63

85

86

86
84

86

84

84

84

114

185

186

185

186

186

186

186

52

53

348

52

348

34

34

142

136

197

196

194

105

55

34

34

$\begin{array}{r}34 \\ 34 \\ \hline\end{array}$

136

210

38

99

200

200

201 


\begin{tabular}{|c|c|c|c|c|c|}
\hline \multirow{2}{*}{ Name. } & \multirow{2}{*}{$\begin{array}{l}\text { This } \\
\text { work. }\end{array}$} & \multicolumn{3}{|c|}{$\begin{array}{l}\text { Blanco's Flora de } \\
\text { Filipinas. }\end{array}$} & \multirow{2}{*}{$\begin{array}{l}\text { Novis- } \\
\text { sima } \\
\text { Appen- } \\
\text { dix. }\end{array}$} \\
\hline & & $\begin{array}{l}\text { First } \\
\text { edition. }\end{array}$ & & $\begin{array}{c}\text { Third } \\
\text { edition. }\end{array}$ & \\
\hline \multirow{2}{*}{$\begin{array}{l}\text { Ficus aspera volubilis Blanco } \\
\text { dicarpa Blaneo }\end{array}$} & 79 & 676 & 472 & $3: 8: 2$ & 201 \\
\hline & 79 & 682 & & & 200 \\
\hline glomerata Blanco & 79 & 682 & 475 & $3: 87$ & 201 \\
\hline lanco---.- & $\begin{array}{l}79 \\
79\end{array}$ & 684 & 476 & 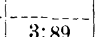 & 202 \\
\hline hispida Blanco & 79 & $\begin{array}{l}68.9 \\
685\end{array}$ & 476 & & 200 \\
\hline hispida hastata Blanco.... & 79 & $68 \overline{3}$ & 476 & $3:$ & 200 \\
\hline hispida linearis Bla & 79 & 685 & 476 & $3: 88$ & 200 \\
\hline hispida odorata Blan & 79 & 686 & 476 & $3: 89$ & 200 \\
\hline inn & 78 & 681 & 473 & 3: & 199 \\
\hline 3lanco-.. & 80 & 673 & 468 & $3: 80$ & 202 \\
\hline lae & 79 & 682 & 474 & & 202 \\
\hline lat & 79 & & 475 & $3: 87$ & 202 \\
\hline nep & 79 & & 474 & $3: 8 ;$ & 200 \\
\hline & 79 & $6 \times 3$ & 475 & $3: 86$ & 199 \\
\hline pse & 80 & 680 & 473 & $3: 84$ & 202 \\
\hline rost & 79 & 679 & 472 & $3: 83$ & 201 \\
\hline scabra Blanco & 79 & & 471 & $3: 81$ & 201 \\
\hline Filices & 94 & & & & 326 \\
\hline Fissilia psittacorum Blanco & 32 & 28 & 20 & $1: 38$ & 45 \\
\hline \multirow{2}{*}{$\begin{array}{l}\text { Flacourtia corollata Blanco } \\
\text { parvifolia Blanco }\end{array}$} & 18 & & 5.59 & $3: 220$ & 12 \\
\hline & 18 & & 560 & $3: 220$ & 12 \\
\hline Flagellaria indica Linn & 87 & & 196 & $1: 347$ & 263 \\
\hline \multirow{2}{*}{$\begin{array}{l}\text { Fucus denticulatus Blanco } \\
\text { edulis Blanco }\end{array}$} & 95 & 839 & & & \\
\hline & 95 & & 580 & $3: 259$ & \\
\hline $\begin{array}{l}\text { gulaman Blaneo } \\
\text { natans Blanco }\end{array}$ & 95 & 839 & 579 & $3: 259$ & \\
\hline \multirow{2}{*}{$\begin{array}{l}\text { prolifer Blanco } \\
\text { Fusanus parasitus Blanco }\end{array}$} & 95 & 838 & 579 & $3: 259$ & \\
\hline & 75 & & 53 & 00 & 184 \\
\hline \multirow{2}{*}{$\begin{array}{l}\text { Galactia terminiflora Blanco } \\
\text { Galedupa frutescens Blanco }\end{array}$} & 37 & & 411 & $2: 390$ & 59 \\
\hline & 40 & 559 & 391 & & 68 \\
\hline $\mathrm{m} \varepsilon$ & 40 & 559 & 390 & & 68 \\
\hline Blan & 38 & 558 & 390 & $2: 352$ & 59 \\
\hline entianace & 61 & & & $-\ldots$ & 136 \\
\hline & 26 & & & & 32 \\
\hline btrilobe & $\begin{array}{l}26 \\
65\end{array}$ & 182 & 130 & & $\begin{array}{r}28 \\
150\end{array}$ \\
\hline & 85 & 260 & 181 & $1: 3: 24$ & 253 \\
\hline Blane & 44 & & 266 & & 80 \\
\hline 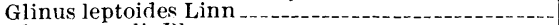 & 50 & 413 & 288 & $2: 169$ & 100 \\
\hline & 75 & & 451 & $3: 49$ & 187 \\
\hline & 40 & 578 & & & \\
\hline Gmelina a & 68 & 492 & 344 & & 159 \\
\hline & 68 & 493 & 345 & $2: 274$ & 159 \\
\hline Gnaphalium dichotc & 55 & -- & 439 & $3: 20$ & 116 \\
\hline & 82 & & & & 210 \\
\hline & 82 & 747 & 514 & & 210 \\
\hline itifolia Blanco_ & 45 & 299 & 208 & $2: 25$ & 351 \\
\hline Goodeni & 56 & & & & 120 \\
\hline Gomphrena $\mathrm{g}$ & $\begin{array}{l}71 \\
71\end{array}$ & $\begin{array}{l}198 \\
199\end{array}$ & $\begin{array}{l}139 \\
140\end{array}$ & & $\begin{array}{l}170 \\
17 \cdot 2\end{array}$ \\
\hline & 48 & 549 & 384 & & 94 \\
\hline Gossypium he & 24 & 534 & 374 & & \\
\hline & 24 & 589 & 378 & $2::$ & 25 \\
\hline & 24 & 537 & 376 & 330 & 26 \\
\hline & 24 & & 376 & $2: 329$ & 25 \\
\hline Gouania domingensis Blanco & 33 & 196 & 138 & $1: 2 \cdot 18$ & 49 \\
\hline & 91 & & & & 310 \\
\hline & 65 & 11 & & & $\begin{array}{r}149 \\
30\end{array}$ \\
\hline Grewia $\mathrm{m}$ & 26 & & $\begin{array}{l}310 \\
309\end{array}$ & $2: 209$ & 30 \\
\hline & & & 309 & $2: 209$ & 30 \\
\hline & 45 & & & & 30 \\
\hline & 45 & 187 & 132 & $1: 236$ & \\
\hline Guaiacum abil & 30 & 364 & & $-\ldots$ & 40 \\
\hline Guettarda jazr & 51 & 722 & & & 103 \\
\hline & 58 & -.. & 500 & $3: 126$ & 127 \\
\hline sper & 51 & -0 & 499 & $3: 124$ & 103 \\
\hline & 21 & 723 & 500 & $3: 125$ & 18 \\
\hline Guilandina bonducella Linn & 41 & 343 & 239 & $2: \times 1$ & 69 \\
\hline nuga Linn & 41 & 344 & 240 & $2: 81$ & 69 \\
\hline Gyrocarpus lobatus Blanco & 45 & & 54 & $1: 103$ & \\
\hline
\end{tabular}


Gyrocarpus pendulos Blanco

Haemanthus pubescens Blanco

Halesia termata Blanco

Hedysarum pulchellum Linn

vespertilionis Linn.

Helianthemum triflorum Blaneo

Helicteres apetala Blanco

pinnata Blanco

Heliotropium parviflorum Blanco

Helminthostachys duleis Kaulf

Hemionitis incisa Blanco

Hernandia sonora Blanco

Heritiera tinetoria Blanco
Hibiseus abelmoschus Linn

Hibiseus abelmoschus Linn
batacensis Blanco

bifureatus Blaneo -

populneus Linn -..
rosa-sinensis Linn

rosa-sinensis Lin

Hillia longiflora Blanco

Hippocratea volubilis Blanco

Hippocrepis comosa Blanco

humilis Blanco

multisiliquosa Blanco

rhomboidea Blanco

Hiraea reclinata Blanco

Holcus saccharutus Linn -

Hoya carnosa Blanco

Hydnocarpus polyandra Blaneo

Hyd rocharidea

Hydrocotyle asiatica Linn monopetala Blanco

Hydrolea arayatensis Blanco zeylanica Vahl

Hydrophyllacex

Hypericacere

Hyperieum aegyptium Blanco

olympicum Blaneo-
pentandrum Blanco

Icica abilo Blanco

Ignatia amara Linn. f

Illecebrum lanatum L

Impatiens triflora Blaneo

Indigofera angustifolia Blanco

argenteg Blanco

hirsuta Blanco

senegalensis Blaneo

tinctoria Blanco

Inga lanceolata Blanco

Ipomoea hepaticifolia Blaneo

quamoclit Linn

Iridacer -

glandulosa Blanco

manila Blanco

Jatropha enreus L

janipha Blaneo, non $\mathrm{L}$

maniluot Linn

Jurglandacere

Jussiaea erecta Blanco.-

incliuata Blanco

fluviatilis Blaneo

Justicia dalaora Blanco_ ecbolium Blaneo gendarussa Blanco nasuta Linn

picta Linn

viridis Blanco

Kadsura blancoi Az:1ola

Kaempferia rotunda Blaneo

This

work.

Blaneo's Floru de Filipinas.

Novis-

sima

First Seeond Third Appenedition, edition. edition. dix.

\begin{tabular}{|c|c|c|}
\hline 23 & 55 & $1: 104$ \\
\hline 399 & 279 & $2: 153$ \\
\hline & 407 & $2: 382$ \\
\hline $3 \times 3$ & 309 & $2: 208$ \\
\hline
\end{tabular}

tixy

603

$3: 93$

\begin{tabular}{l|l}
$3 \times 0$ & $2: 335$ \\
\hline & $2: 335$
\end{tabular}

544

545

380

380

381

$2: 3344$

$2: 334$

\section{$5+1$}

543

541

23i

379

379

$2: 3: 36$

165

$2: 333$

$2: 332$

$1: 297$

$1: 27$

584

585

584

$58 \pi$

378

47

1:- ----

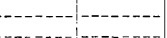

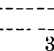

32

$1: 58$
$1: 257$

\begin{tabular}{r|r|r} 
& 545 & $3: 200$ \\
\hline 212 & 149 & $1: 268$
\end{tabular}

213

211

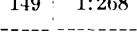

-...-

14

61

613

614

190

636

596

591

j) 91

¿91

97

97

61
59

59
61

61
709
758

758

760

365

366

14

14

14
14
12

12

15

15

84

5

\section{$1: 266$}

$2: 418$

429

430

2: 416

2: 417

$256 \quad 2: 113$

.

443 3:32

$415: 2: 394$

$415: 2: 394$

$415: 2: 392$

413 2:393

\begin{tabular}{l|l}
370 & $2: 322$ \\
\hline
\end{tabular}

$72 \quad 1: 134$

72 1:134

$42 \quad 1: 78$

$41 \quad 1: 76$

42 1:78

4. $1: 77$

$522 \quad 3: 160$

\begin{tabular}{l|l}
521 & $3: 159$ \\
\hline
\end{tabular}

522: $3: 160$

257 $2: 114$

$257 \mid 2: 114$

$10 \quad 1: 10$

10 1:18

10 1:19

10 1:19

9 1:18

\begin{tabular}{r|l}
11 & $1: 21$ \\
594 & $3: 118$
\end{tabular}

\begin{tabular}{r|l|}
494 & $3: 118$ \\
4 & $1: 7$
\end{tabular} 
Name.

This

Blaneo's Flora de Filipinas.

Novis-

work. First / Second/Third Appenedition. edition. edition. dix.

Kirganelia alba Blanco nigrescens Blanco

pumila Blanco

triand ra Blanco

villosa Blanco

Kleinhovia hospita Linn scrpata Blanco

Knautia sagittata Blanco.

Koclreuteria arborea Blanco edulis

Kyllingia triceps Blanco

Kyrtandra aristata Blanco capsularis Blanco personata Blanco

Labiatæe serrata Blanco

Lablab cultrutus IOC

Lagerstroemia indiea $\mathrm{L}$

Lansium domesticum Rumph

Lantana viburnoides Blanco

Lauracese

Laurus cassia Blanco cinnamomum Blanco. culilaban Blanco

hexandra Blanco

年-

martinicensis Blanco

perseg $\mathrm{L}$

serrata Blanco

Lawsonia inermis Roxb

Lechea minor Blanco.

Leea aculcata Blanco sambucina Blanco

Legazpia triptera Blanco

Legnotis lanceolata Blanco

Leguminose

Lemnaces

Lemna gibba Blanco

Ligustrum quad riloculare

Iiliacere

Limonia corymbrsa Blanco disticha Blanco
glutinosa Blanco
laureola Blanco
linearis Blanco
monophylla Linn
trifoliata Limn

Liparia badocana Blanco

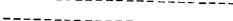

Llanosia toquian Blanco

Loganiaceæ

Lonicera symphoricarpos Blanco

Loranthaceæ

Loranthus pauciflorus Blanco philippinensis Cham and Schlecht

Lumanaja fluviatilis Blanco

Lunasia amara Blanco

Lupinus angustifolius Blanco

Lycopodiaceæ

Lycopodium dichotomum Blaneo

Lythraceæ gnidioides Blanco

Macanea arborea Blanco

Maesa m'mbranacea Blanco

Magnoliaceæ

Magnolia angatensis Blanco

Malaisia tortuosa Blanco.-

Malesherbia globosa Blanco.

Mallorocca parva Blanco

Malphigiaceæ

Malvaceæ -

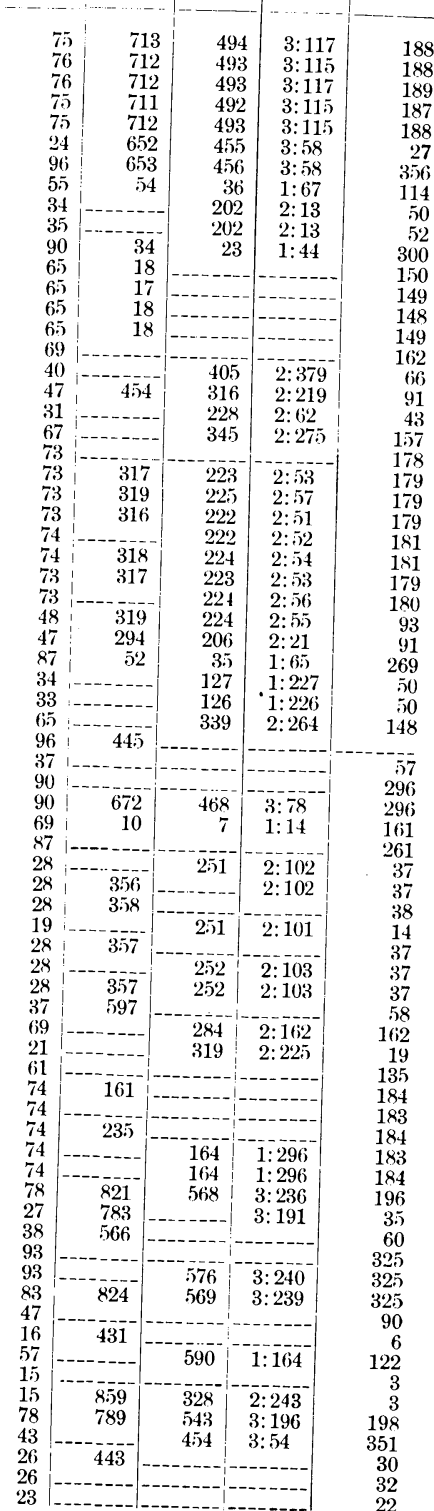


Name.

Malva coromandeliana Blanco luzonica Blanco. moschata Blanco -

Mamboga capitata Blanco

Mangifera altissima Blanco anisodota Blanco

pinnata Blanco rostrata Blanco

Manungala pendula Blanco

Maranta arundinacea Blanco

Marchantia

Marrubium indicum Blanco

Marsdena parasita Blaneo akkar Blanco -

Marsileacere tagudina Blanco

Marsilea minuta Blancotrifolia Blanco

Matricaria chamomilla Blanco

Melaleuca grandiflora Blanco

Melastomatucea

Melastoma aspera Blanco dodecandra Blanco malabarica Blanco. obvoluta Blanco tamonea Blanco

Meliaceæ

Melia azedarach Blanco

iloilo Blanco

Melicocca triptera Blanco

Melicope conferta Blanco tetandra Blanco.

Mallococea crenata Blanco

Melochia arborea Blanco supina Linn .

Memecylon lanceolatum Blaneo parviflorum Blanco
tinctorium Blanco

Menais mollis Blanco

Menispermaceæ

Menispermum cocculus Linn rimosum Blanco.

Mentha auricularia Blanco cablin Blanco

crispa Blanco
Menyanthes indica Bory

Metrosideros pictapetala Blanco

Mezoneurum procumbens Blanco

Michelia champaca Linn ...

Millingtonia pinnata Blanco

quadripinnata Blanco

Mimosa acle Blanco asperata blanco carisquis Blanco coriaria Blanco scutifera Blanco lebbek Blanco.

membranulacea Blanco

peregrina Blanec

punctata Blanco

quadrivalvis Blanco

tenuifolia Blanco

unguis-cati Blanco

virgata Blanco

Mimulus violaceus Blanco.

Mimusops talosan Blanco.

Mirabilis longiflora Blaneo

Miroxylum dicline Blanco

Mocanera grandiflora Blanco
Blanco's Flora de Filipinas.

Novissime

work. : First Second|Third Appenedition.edition.edition dix.

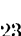

26

52

35

36

35

29

84
95

69

(i1

60

60
93

93
43

98

56

24

46

46

47

47
46

47

30

30

30

31

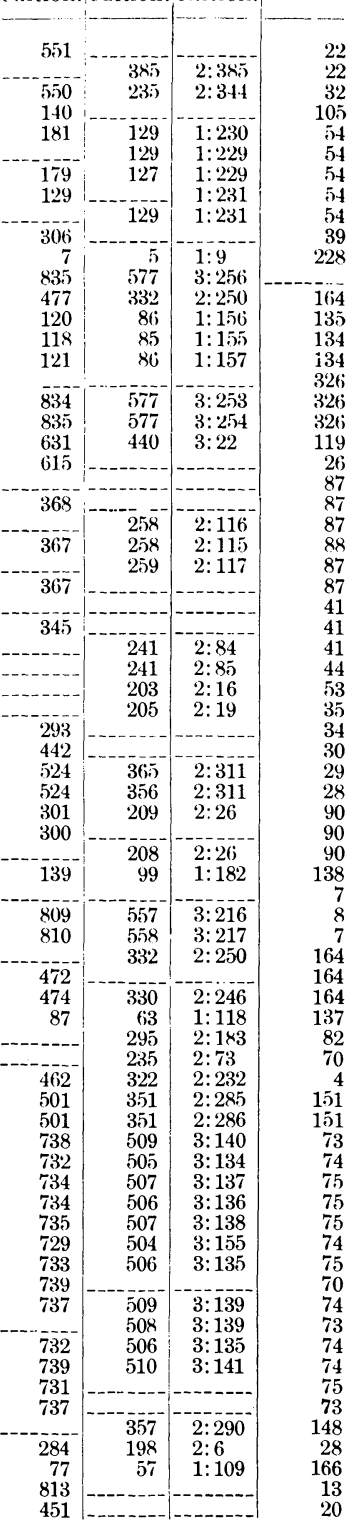


Name.

Mocanera guiso Blaneo

maluanonan Blanco

mallgachapoi Blanco

mayapis Blanco

plagata Blauco

pol ysperma Blanco

thurifera Blanco

vernicifluua Blanco

Modecea coccinea Blanco

parviflora Blanco

saponaria Blanco

triloba Blanco --

Mogorium aculeatum Blanco

Molinaea arborea Blanco

Mollugo stricta Linn

subserrata Blanco

Momordica balsamina Linn cylindrica Blanco operculata Blanco. sphaeroidea Blanco

Monodora myristica Blaneo

Morinda citrifolia Blanco

ligulata Blanco

litoralis Blanco

umbellata Blanco

Moringaceat

Moringa oleifera Lam

Morus alba Linn

luzonica Blanco

tinetoria Blaneo

Moschosma tenuiflorum Blanco

Munchausia speciosa Linn

Murraya cerassiformis Blanco

exolica Blanco

lobata Blanco

odorata Blanco

Musa paradisiaca Limn

cinerea Blanco

compressa Blanco

glaberrina Blunco.

glauca Blanco.

lacatan Blanco

longa Blanco.

magn: Blaneo

maxima Blanco

pumila Blanco

subrubea Blanco

surveolens Blaneo

termatensis Blanco

tombak Blanco

ulnaris Blanco

violacea Blanco

troglodytarum Linn

dolioliform is Blanco

errans Blanco.

textoria Blanco

Mussaenda frondosa Blanco

Myriotheca arborescens Blanes

Miristicacese

Myristica luzonica Blanco

Myrsinacex

Myrtacese

Myrtus communis Blanco

mananquil Blanco

subrubens Blanco

tripinnata Blanco

Naiadacere

Naias lobeta Blanco

obvoluta Blaneo

palustris Blanco

Nama jamaicensis Blanco
Blanco's Flora de Filipinas.

This work.

First |Second Third Appen edition edition edition dix.

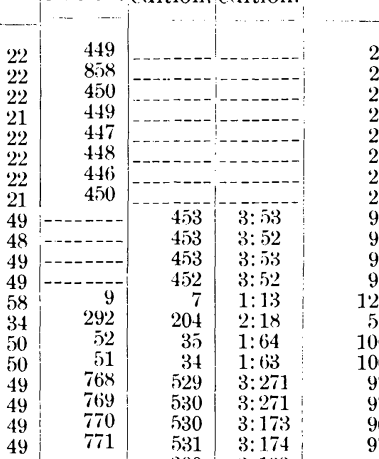

6
111

111

111

111

111

56

56

199

198

202

163

91

35

35

35

38

215

215

216

218

216

216

217

217

217

216

217

216

217

217

217

216

218

218

218

218

107

326

177

17

122 


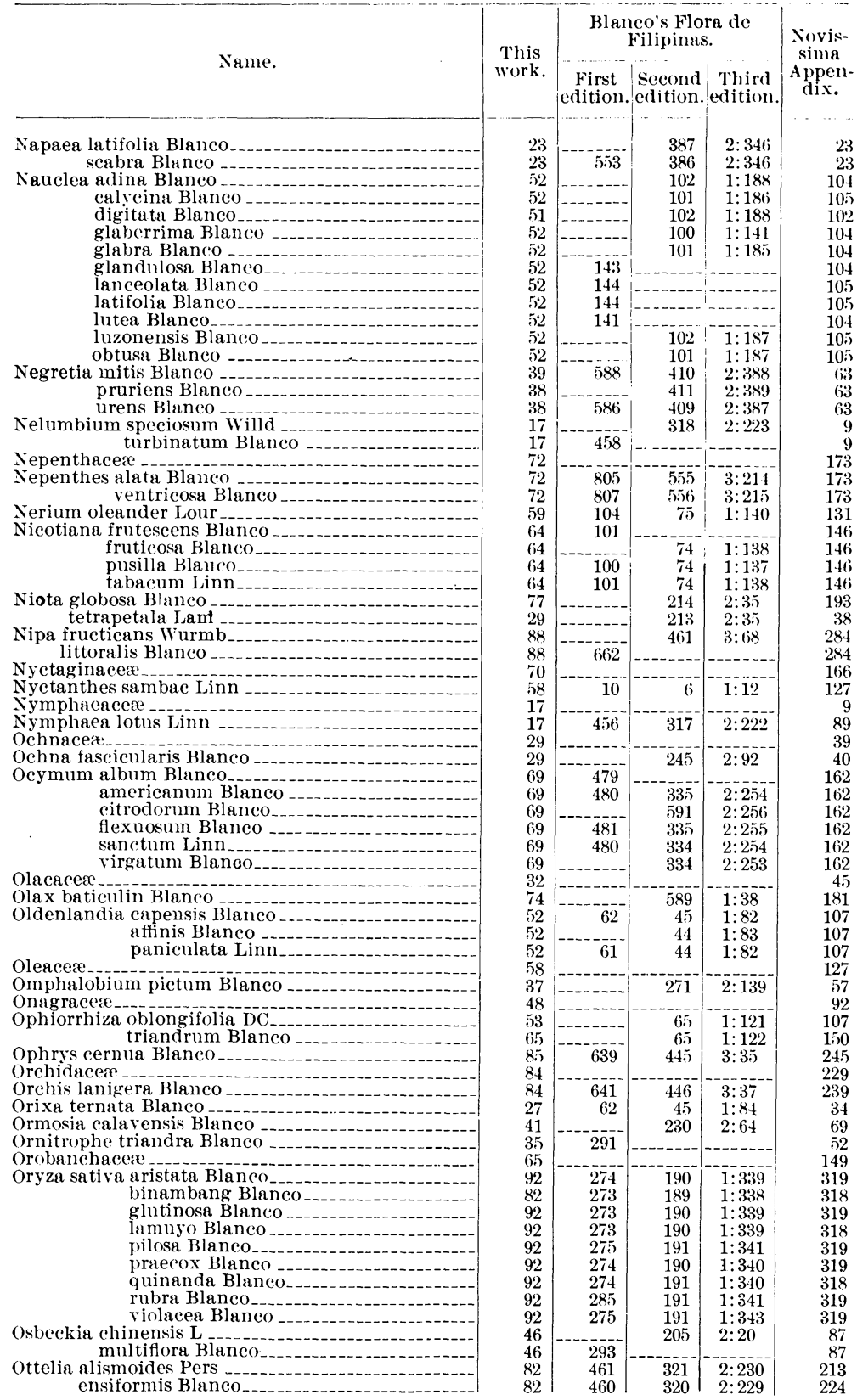




\begin{tabular}{|c|c|c|c|c|c|}
\hline \multirow{2}{*}{ Name. } & \multirow{2}{*}{$\begin{array}{l}\text { This } \\
\text { work. }\end{array}$} & \multicolumn{3}{|c|}{$\begin{array}{c}\text { Blanco's Flora de } \\
\text { Filipinas. }\end{array}$} & \multirow{2}{*}{$\begin{array}{l}\text { Novis- } \\
\text { sima } \\
\text { Appen- } \\
\text { dix. }\end{array}$} \\
\hline & & $\begin{array}{l}\text { First } \\
\text { edition }\end{array}$ & $\begin{array}{l}\text { Second } \\
\text { cdition. }\end{array}$ & $\begin{array}{l}\text { Third } \\
\text { edition. }\end{array}$ & \\
\hline $\begin{array}{c}\text { Oxalis acetosella Blanco } \\
\text { sensitiva Blanco }\end{array}$ & 27 & 388 & 272 & $2: 141$ & 32 \\
\hline $\begin{array}{l}\text { sensitiva Blalleo } \\
\text { Pachyrhizus angulatus Rich-- }\end{array}$ & $\begin{array}{l}27 \\
40\end{array}$ & 389 & 405 & $2: 380$ & $\begin{array}{l}33 \\
6.5\end{array}$ \\
\hline jicamas Blanco.. & 40 & 579 & & & 65 \\
\hline montanus Blance & 39 & & 406 & $2: 381$ & 64 \\
\hline $\begin{array}{l}\text { teres Blanco--.- } \\
\text { Paederia foetida Blanco }\end{array}$ & 39 & 580 & & & \\
\hline $\begin{array}{r}\text { Paederia foetida Blanco } \\
\text { tacpo Blanco }\end{array}$ & 54 & 159 & 112 & 1:201 & 112 \\
\hline $\begin{array}{r}\text { tacpo Blai } \\
\text { Palaquium lanceola }\end{array}$ & 54 & 160 & 113 & $1: 202$ & 112 \\
\hline $\begin{array}{l}\text { Palaquium lanceols } \\
\text { latifoliu }\end{array}$ & 57 & $\begin{array}{l}403 \\
405\end{array}$ & 282 & $\begin{array}{l}2: 159 \\
2: 159\end{array}$ & 124 \\
\hline oleiferum Blar & 57 & 405 & $\begin{array}{l}282 \\
283\end{array}$ & $2: 160$ & $\begin{array}{l}124 \\
125\end{array}$ \\
\hline Paliurus dao Blaneo & 36 & 174 & 122 & $1: 219$ & 56 \\
\hline dubius Blanco & 29 & 175 & 123 & $1: 121$ & 39 \\
\hline $\mathrm{O}_{-1-1}$ & $\begin{array}{l}36 \\
36\end{array}$ & 173 & 122 & & $\begin{array}{l}56 \\
56\end{array}$ \\
\hline perforatus Blanco & 29 & 174 & 122 & $1: 220$ & 39 \\
\hline N & 88 & & & & 273 \\
\hline Panax fruticosa Blanco & 51 & & 156 & $1: 281$ & 101 \\
\hline Pancratium amboinense Linn & 86 & 252 & 177 & $1: 317$ & 256 \\
\hline illyr & 86 & 251 & 176 & $1: 315$ & 256 \\
\hline murit & 86 & 252 & 177 & $1: 316$ & 256 \\
\hline zeylanicum Linn & 86 & 253 & 177 & $1: 317$ & 256 \\
\hline Pandanacex & 89 & & & & 284 \\
\hline Pandunus exalta & 89 & 778 & 536 & 183 & 284 \\
\hline$\underset{\text { iner }}{\text { grac }}$ & 89 & 778 & 536 & $3: 182$ & 285 \\
\hline inermis Blanco & 89 & & 537 & $3: 184$ & 285 \\
\hline & 89 & & 536 & $3: 182$ & 284 \\
\hline radic & 89 & 780 & 537 & $3: 184$ & $28 \%$ \\
\hline$-\ldots$ & 89 & 779 & 537 & 183 & 285 \\
\hline spirs & 89 & 777 & 535 & $3: 181$ & 284 \\
\hline Panicum miliaceum Blanco & 91 & 39 & 28 & $1: 52$ & 312 \\
\hline$--n-1-1$ & 17 & & & & \\
\hline Paratropia cras & 51 & & 158 & $1: 28: 3$ & 102 \\
\hline 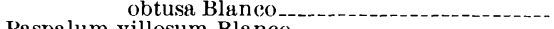 & 51 & & 159 & 85 & 102 \\
\hline $\begin{array}{l}\text { Paspalum villosum Blanco } \\
\text { Passifloraceæ }\end{array}$ & $\begin{array}{l}91 \\
48\end{array}$ & 40 & 28 & $1: 53$ & $\begin{array}{r}310 \\
95\end{array}$ \\
\hline Passiflora coccines & 49 & 650 & & & $9 \overline{9}$ \\
\hline $\mathrm{m}$ & 48 & 647 & & & 95 \\
\hline D....... & 48 & 649 & & & 95 \\
\hline 2. & 49 & 650 & & & $9 \pi$ \\
\hline - n & 48 & & 452 & $3: 50$ & $9 \tilde{5}$ \\
\hline & 49 & 648 & & & 95 \\
\hline Pavetta meinbra & 54 & 59 & & & 111 \\
\hline sumbueina Blaneo & 54 & -- & 41 & & 111 \\
\hline Pedaliaceæ _...-_ _- & 66 & & & & 152 \\
\hline Pemphis setosa Blanco & 47 & 410 & 285 & & 91 \\
\hline Pentapetes cebuana Blanco & 25 & 529 & 369 & $2: 319$ & 28 \\
\hline cod & 25 & 529 & & & \\
\hline m Blaneo & 55 & 630 & 439 & & 115 \\
\hline Pergularia glab & 60 & & 141 & $1: 254$ & 134 \\
\hline$(0$ & 60 & 201 & 141 & $1: 254$ & 134 \\
\hline 11100 & 60 & 201 & & & 134 \\
\hline Petaloma alba $\mathrm{Bl}$ & 44 & 3.44 & 240 & & 81 \\
\hline cocei & 44 & 345 & 240 & & 80 \\
\hline Phalaenopsis amal & 84 & & 592 & $3: 41$ & 243 \\
\hline Phaseolus bulai $\mathrm{Bl}$ & 37 & 572 & & & 57 \\
\hline cg & 39 & 575 & 401 & $2: 372$ & 65 \\
\hline ----_-- & 39 & 572 & & & 64 \\
\hline - & 39 & 571 & 399 & & 64 \\
\hline lunat & 39 & 573 & 400 & $2: 370$ & 64 \\
\hline 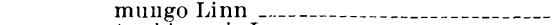 & 39 & 573 & 400 & & 65 \\
\hline r & 39 & & 399 & $2: 369$ & 64 \\
\hline$-\ldots \ldots$ & 39 & 574 & & & \\
\hline & 39 & & 401 & $2: 371$ & 64 \\
\hline Phlomis alba Bla & 70 & 474 & 330 & $2: 247$ & 165 \\
\hline zeylanica Blanco & 70 & 475 & 331 & $2: 248$ & 165 \\
\hline Phyllanthis carolinianus Blanco & 76 & 691 & & & 189 \\
\hline kirganelia Blanco & 76 & & 480 & $3: 96$ & 189 \\
\hline i Blaneo & 76 & 690 & & & 189 \\
\hline tetrander Blanco & 76 & & 480 & $3: 117$ & 189 \\
\hline Physalis angulata Linn & 64 & 138 & 99 & & 144 \\
\hline Feruviana Linn & 64 & 138 & $9 \times$ & $1: 180$ & 144 \\
\hline
\end{tabular}


Name.

Physalis pubescens Linn

Pilocarpus amara Blanco

Pinus treda Blanco

Piperacere

Piper anisodorum Blanco

anisumolens Blanco

betel Blanco.

nigrum Linn

obliquum Blanco

parvifolium Blanco

Pisonia aculeata Linn

Pistia stratiotes Linn

Pittosporacere

Plagianthus humilis Blanco

Plantaginacere.

Plantago crenata Blanco media Blanco.

Plinia paniculata Blanco

Plumbaginacea

Plumbago rosea Linn
viseosa Blanco

Plumieria alba Blanco

Poinciana pulcherrima Linn

Polanisia viscosa DC

Polemonium obscurum Blanco

Polyanthes tuberosa Linn

Polycarpon pholyphyllum Blanco

Polvgalaceæ

Polygala monspeliaca Blanco

Polygonacea

Polygonum bellardi Blanco stoloniferum Blanco

Polyozus bipinnatus Blanco

Polypodium adiantiforme Blanco phymatodes Linn quercifolium Liun serratum Blanco signatum Blanco

Polyscias digitata Blanco

-

obtusa Blanco

odorata Blanco

Pongatium spongiosum Blanco

Pontederiace

Pontederia vaginalis Blanco

Porana volubilis Burm

Portesia rimosa Blanco

Portulacacese

Portulaca a xillifiora Blanco meridiana Linn oleracea Linn toston Blanco

Pothos pinnata Blanco

Poupartia pinnata Blanco

Premna cordata Blaneo --. integrifolia Blanco nauseosa Blanco odorata Blanco. serratifolia Blanco tomentosa Blaneo

Prockia albicans Blanco

Procris erecta Blanco violacea Blanco--

Prunus armeniaca Blanco

Psidium aromaticum Blanco pyriferum Blanco.

Psoralea badocana Blanco

Pteris grandifolia Blanco. piloselloides Blanco. sinuata Blanco signata Blanco
This work

Blanco's Flora de Filipinas.

Novissima

First Second/Third Appen edition. edition.edition. dix.

\begin{tabular}{|c|c|c|}
\hline 138 & 98 & $1: 181$ \\
\hline 767 & 528 & $3: 169$ \\
\hline$\cdots$ & 16 & $1: 31$ \\
\hline 23 & & \\
\hline 22 & 16 & $1: 30$ \\
\hline 21 & 16 & $1: 29$ \\
\hline 22 & 16 & $1: 30$ \\
\hline 23 & 17 & $1: 32$ \\
\hline 195 & 137 & $1: 247$ \\
\hline 651 & 454 & $3: 5 \overline{5}$ \\
\hline 526 & 366 & $2: 315$ \\
\hline 56 & --- & 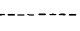 \\
\hline & 38 & 170 \\
\hline 423 & 296 & $2: 184$ \\
\hline 78 & 58 & $1: 111$ \\
\hline 78 & 58 & $1: 111$ \\
\hline 111 & 80 & $1: 148$ \\
\hline 333 & 232 & $2: 69$ \\
\hline & 364 & $2: 308$ \\
\hline 103 & $\begin{array}{r}75 \\
181\end{array}$ & $1: 139$ \\
\hline 53 & 36 & $1: 060$ \\
\hline 557 & 388 & $2: 350$ \\
\hline
\end{tabular}


Name.

Pteris trichomanoides Blanco

Pterocarpus diadelphus Blanco

frutescens Blanco

pallidus Blanco

santalinus Blanco.

Pterospermum hastatum Blanco obliquum Blanco

semisagittatum Blanco

Punica granatum Linn

Pycnanthemum decurrens Blanco elongatum Blanco subulatum Blanco

Quassia simaruba Blanco

tricarpa Blanco

tricarpa Blanco

Quercus cerris Blanco

concentrica Blanco

cooperta Blanco

glabra Blanco.

molucca Blanco

Quilamum luteum Blanco

Quilesia sericea Blanco

Quirosia anceps Blanco

secunda Blaneo.

Quisqualis indica Linn spinosa Blanco.

Rafflesia lagascæ Blanco philippinensis Blanco-

Randia aculeata Blanco

Ranunculaceæ

Reichardia pentapetala Blanco

Reichelia palustris Blanco.

Remijia angatensis Bianco obscura Blanco odorata Blanco

Renealmia gracilis Blanco

Rhamnacere exaltata Blanco

Rhamnus carolinianus Blanco dalanta Blanco. jujuba Linn . talanai Blanco zizyphus Blanco

Rhaphis trivalvis Lour

Rheum muricatum Blanco

Rhizophoraceæ

Rhizophora candel Blanco gymnorrhiza $\mathrm{Linn}$

longissima Blanco

mangle Iinn.

plicata Blanco

polyandra Blanco tinctoria Blanco

Riana tricapsularis Blanco

Ricinus communis Linn

Ronabea arborea Blanco

$$
\text { bipinnata Blanco }
$$

Rondeletia asiatica Blanco

Rosaceæ

Rosmarinus offieinalis Linn

Rubiacea

Rubus comintanus Blanco

$$
\begin{aligned}
& \text { idaeus Blanco } \\
& \text { jamaicensis Blanco } \\
& \text { moluccanus Linn }
\end{aligned}
$$$$
\text { (1) }
$$

repens

secunda Blanco

uliginosa Blanco

Rumex muricatus Blanco

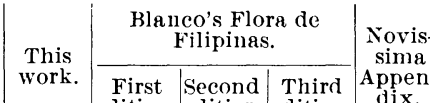
edition. edition. edition. dix.

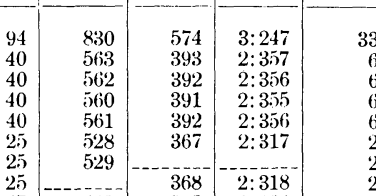

$2: 184 \quad 9$.

2:251 $\quad 164$

$2: 252 \quad 164$

$2: 251 \quad 164$

$2: 94 \quad 51$

$2: 94 \quad 51$

2: $94 \quad 350$

3:130 209

3:129 208

208

208

208

208 
Name.

Rutaceæ

Saccharum koenigii Blanco

officinarum Linn

Salacia sinensis Blanco.

Salceda montana Blanco

Salgada lauriflora Blanco

Salicaceæ

Salix azaolana Blanco

Salvadoraceæ

Salvia violacea Blanco

Sambucus javanica Blume

Samydaceæ

Samyda pubescens Blanco

serrulata Blanco

trialvis Blanco.

Sandoricum indicum Cav -

ternatum Blanco

Sapindaceæ

Sapindus baccatus Blanco
edulis Blanco

guisian Blanco

koelreuteria Blanco

Sapotaceæ

saponaria Blanco.

Sapota nigra Blanco

Saxafragaceæ

Scaevola lobelia Blanco

Schmidelia conferta Blanco triandra Blanco

Schotia speciosa Blanco

Scitiminere

Scirpus niloticus Blanco

Sclerotium subterraneum Blanco

Scoparia dulcis Linn

Scrophulariaceæ

Sebifera glutinosa Lour

balongai Blanco

Securidaca complicata Blanco

volubilis Blanco

Semecarpus anacardium Blanco

Senecio caliaster Blanco

Seringia lanceolata Blanco

Serissa my rtifolia Blanco

pinnata Blanco-

Serratula multiflora Blanco

Sesbania cannabina Blanco grandiflora Pers

Sesuvium portulacastrum Linn

Sida frutescens Blanco.

indica Linn

lanceolata Roxb

philippica DC

semicrenata Link

truncatula Blanco

Sideroxylon balitbitan Blanco

Simarubacexe duclitan Blanco

Sinapis brassicata Linn . juncea Linn -

Smilax divaricata Blanco fistulosa Blanco.

latifolia Blanco

pseudochina Blanco

Smithia bigeminata Blanco

Soala litoralis Blanco

Solunaceæ

Solanum coagulans Blanco

lycopersicum Linn.

$21896-9$

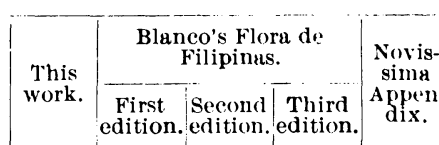

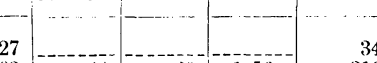

\begin{tabular}{l|l|r|r|r}
92 & 44 & 30 & $1: 56$ & 316
\end{tabular}

\begin{tabular}{l|l|l|l|l}
92 & 42 & 29 & $1: 55$ & 317
\end{tabular}

\begin{tabular}{l|r|r|l|r}
32 & 26 & 19 & $1: 36$ & 47 \\
21 & & 374 & $2: 327$ & 19
\end{tabular}

\begin{tabular}{l|l|l|l|r}
21 & ---13 & 374 & $2: 327$ & 19 \\
-13 & -21 & $2: 50$ & 179
\end{tabular}

81 -

81 - 539 3:188 210

$58 \quad 128$

70 - $14{ }^{-1: 27}$

\begin{tabular}{l|l|l|l}
51 & 151 & $1: 271$ & 103
\end{tabular}

48 (a) 93

48 - 263 2:124

$48 \quad 374$

\begin{tabular}{ll|l|l|l|}
48 & 374 & 263 & $2: 124$ & 93 \\
31 & & 242 & $2: 85$ & 49
\end{tabular}

\begin{tabular}{l|l|l|l|l}
31 & -342 & $2: 85$ & 42
\end{tabular}

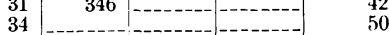

35 290

34 - $201 \quad 2: 12 \quad 51$

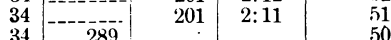

289 -

\begin{tabular}{l|r|r|r}
34 & 288 & - & 51 \\
\hline 57 & & -124
\end{tabular}

$58 \quad 409 \quad-127$

43 -

56 147 $104 \quad 1: 193 \quad 120$

\begin{tabular}{l|l|l|l}
34 & 147 & $2: 41$ & 51
\end{tabular}

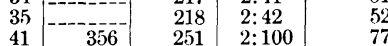

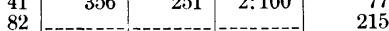

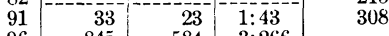

\begin{tabular}{l|r|l|l}
96 & 845 & 584 & $3: 266$
\end{tabular}

\begin{tabular}{l|r|r|r|r}
65 & 55 & 37 & $1: 69$ & 149 \\
64 & & &
\end{tabular}

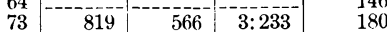

\begin{tabular}{l|l|l|l|l}
74 & 819 & 566 & $3: 233$ & 180 \\
\hline & 820 & 567 & $3: 235$ & 180
\end{tabular}

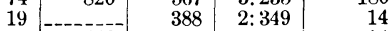

19 556

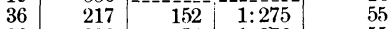

\begin{tabular}{l|l|l|l|r}
36 & 220 & 155 & $1: 276$ & 55
\end{tabular}

56 --_-_- $441 \quad 3: 24 \quad 120$

\begin{tabular}{l|l|l|l|r}
35 & - & 45 & $1: 85$ & 53 \\
53 & 164 & 4 &
\end{tabular}

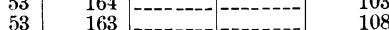

\begin{tabular}{ll|l|l|l}
54 & 617 & 431 & $3: 7^{--}$ & 112
\end{tabular}

\begin{tabular}{l|l|l|l|l}
64 & 507 & 353 & $2: 290$ & 158
\end{tabular}

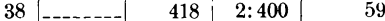

\begin{tabular}{l|r|l|l|l}
38 & 599 & 418 & $2: 399$ & 60 \\
50 & 426 & 297 & $2: 187$ & 99
\end{tabular}

\begin{tabular}{l|l|l|l|l|}
50 & 426 & 297 & $2: 187$ & 99
\end{tabular}

\begin{tabular}{l|l|l|l|l}
23 & - & 384 & $2: 341$ & 22
\end{tabular}

\begin{tabular}{l|r|r|r|r}
23 & 547 & 283 & $2: 339$ & 23
\end{tabular}

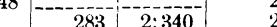

\begin{tabular}{l|l|l|l|l}
23 & ----- & 283 & $2: 340$ & 22 \\
23 & ---- & 348 & $2: 341$ & 22
\end{tabular}

23 - 548 -

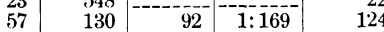

\begin{tabular}{l|l|l|l|l}
57 & 129 & 92 & $1: 168$ & 124
\end{tabular}

29

17 219 362 2:305 10

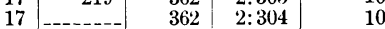

$17-520 \quad 010$

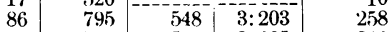

\begin{tabular}{l|l|l|l|l}
87 & 796 & 549 & $3: 205$ & 262
\end{tabular}

\begin{tabular}{l|l|l|l|l}
87 & 548 & $3: 204$ & 262
\end{tabular}

\begin{tabular}{l|l|l|l|r}
87 & 795 & 548 & $3: 204$ & 263 \\
38 & & 395 & $2: 362$ & 60
\end{tabular}

$16{ }^{-43 \overline{7}} \quad 304$ | $2: 199 \quad 5$

63 - 1433

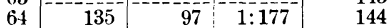

\begin{tabular}{l|l|l|l|l}
63 & 134 & 96 & $1: 176$ & 143
\end{tabular}

\begin{tabular}{l|l|l|l|l}
64 & 134 & 96 & $1: 176$ & 143
\end{tabular} 
Name.

Solanum melongena Linn nigrum Linn serratum Blanco.

sinense Blanco. tuberosum Linn zeylanicum Blanco

Sonneratia pagatpat Blanco

Sputhodea luzonicu Blanco

Spergula serrata Blanco

spermacoce muriculata Blanco

Sphaerauthus alatus Blanco elongatus Blanco indicus Linn

Sphenoclea zeylaniea (irertn

Sophora heptaphylla IDC tomentosa Linn.

Spilanthes acmella Blaneo lobata Blauco . peregrina Blanco.

Spinifex squarrosus Lin1

Spondias dulcis Blanco

Stachys artemesia Lour .

Stalagmites cambogioides Blanco

Stapelia meliflua Blanco. quadrangula Blaneo

Stemodia ruderalis Blanco

sterculiacese

Sterculia alata Blanco -

sterculia balanghas Blanco cordifolia Blanco cymbiformis Blaneo decandra Blanco foetida Linn glandulosa Blanco glomerata Blanco

Stigmarota edulis Blanco Stilugo bunius $L$.

Stipa spinifex Linn

strychnos philippensis Blanco

Stygmanthus cymosus Blaneo

Styracene

sulipa globosa Blanco pseudopsidium Blanco

Syzygium jambolanum DC latifolium Blanco

Tabernaemontana cirrhosa Blanco elliptica

globosa Blaneo

laurifolia Blanco

polygama Blaneo

Taccaceæ

Tacca gaogao Blanco

palma ta Blume
pinnatitida Forst
vesicaria Blanco

Tagetes patula Linn

Tala odorata Blanco

Taligalea umbellata Blanco

Tamarindus indica Linn

Tapogomea rubra Blanco

Tayotum nigrescens Blanco

Tectona grandis Linn. $f$

Terminalia angustifolia Blanco. edulis Blanco.-

latifolia Blanco

mauritiaua Blanco

Ternstroemiaceæ....... sarmentosa Blanco

Tetragonolobus simplicifolius $\mathrm{B}$ anco

Thelymitra malintana Blanco

\begin{tabular}{|c|c|c|c|c|}
\hline \multirow{2}{*}{$\begin{array}{l}\text { This } \\
\text { work. }\end{array}$} & \multicolumn{3}{|c|}{$\begin{array}{c}\text { Blanco's Flora de } \\
\text { Filipinas. }\end{array}$} & \multirow{2}{*}{$\begin{array}{l}\text { Novis- } \\
\text { sima } \\
\text { Appen- } \\
\text { dix. }\end{array}$} \\
\hline & $\begin{array}{l}\text { - First } \\
\text { edition }\end{array}$ & $\left|\begin{array}{l}\text { Second } \\
\text { edition. }\end{array}\right|$ & $\mid \begin{array}{c}\text { Third } \\
\text { edition. }\end{array}$ & \\
\hline 64 & & $\begin{array}{r}-\cdots \\
96\end{array}$ & $1 . \cdots$ & 143 \\
\hline $\begin{array}{l}64 \\
64\end{array}$ & 134 & $\begin{array}{l}96 \\
96\end{array}$ & $\begin{array}{l}1: 167 \\
1: 175\end{array}$ & $\begin{array}{l}143 \\
143\end{array}$ \\
\hline 64 & $\ldots$ & 97 & $1: 179$ & 144 \\
\hline $\begin{array}{l}64 \\
64\end{array}$ & 137 & 97 & $1: 179$ & $\begin{array}{l}144 \\
144\end{array}$ \\
\hline 64 & 136 & $\begin{array}{l}97 \\
97\end{array}$ & $1: 178$ & $\begin{array}{l}144 \\
143\end{array}$ \\
\hline 47 & 424 & 296 & $2: 1 \times 6$ & 92 \\
\hline 66 & & 350 & $2: 284$ & 151 \\
\hline 19 & & 271 & $2: 140$ & 15 \\
\hline 54 & & 44 & $1: 81$ & 113 \\
\hline 54 & & 43 & $1: 80$ & 113 \\
\hline 55 & 635 & & & 116 \\
\hline 55 & 636 & 443 & $3: 30$ & 116 \\
\hline 55 & & 442 & $3: 29$ & 116 \\
\hline 56 & - & 62 & 1: 117 & 121 \\
\hline 40 & 329 & 229 & $2: 63$ & 69 \\
\hline 40 & 328 & 229 & $2: 63$ & 69 \\
\hline 55 & 620 & 433 & $3: 10$ & 118 \\
\hline 55 & 622 & 434 & $3: 11$ & 118 \\
\hline 55 & 622 & 434 & $3: 11$ & 118 \\
\hline 91 & 46 & 31 & $1: 57$ & 313 \\
\hline 36 & 390 & 273 & $2: 143$ & 55 \\
\hline 70 & 476 & 331 & $2: 249$ & 165 \\
\hline 20 & & 301 & $2: 195$ & \\
\hline 60 & 202 & 142 & $1: 256$ & 135 \\
\hline 60 & 202 & 142 & $1: 255$ & 134 \\
\hline 64 & 498 & 346 & $2: 348$ & 147 \\
\hline 24 & & & & 26 \\
\hline 24 & $=-z^{-}$ & 525 & $3: 165$ & 27 \\
\hline 24 & 765 & 525 & $\begin{array}{l}3: 165 \\
3: 163\end{array}$ & $\begin{array}{l}27 \\
26\end{array}$ \\
\hline $\begin{array}{l}24 \\
24\end{array}$ & & & $3: 167$ & $\begin{array}{l}26 \\
27\end{array}$ \\
\hline 24,73 & 766 & 526 & $3: 166$ & 27,178 \\
\hline 24 & 763 & 524 & $3: 162$ & 26 \\
\hline 24,73 & 764 & & $3: 164$ & 27,17 \\
\hline 24,73 & 764 & 525 & $3: 164$ & 27,178 \\
\hline 18 & & 560 & $3: 221$ & 13 \\
\hline 76 & 782 & 539 & $3: 189$ & 191 \\
\hline 91 & 41 & 29 & $1: 54$ & 313 \\
\hline 61 & - & 61 & $1: 116$ & 136 \\
\hline 53 & & 117 & $1: 209$ & 108 \\
\hline 58 & & & & 127 \\
\hline 46 & $\ldots$ & 348 & $2: 2 \times 0$ & 87 \\
\hline 53 & 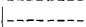 & 347 & $2: 280$ & 109 \\
\hline 46 & & 293 & $2: 180$ & 86 \\
\hline 46 & & 294 & $2: 181$ & 86 \\
\hline 59 & 115 & 83 & $1: 152$ & 132 \\
\hline 59 & 115 & 83 & $1: 152$ & 132 \\
\hline 59 & 116 & 83 & $1: 153$ & 130 \\
\hline 59 & 114 & 82 & $1: 150$ & 130 \\
\hline 59 & & 82 & 1: 151 & 130 \\
\hline 86 & & $-\cdots$ & $\ldots$ & 257 \\
\hline 86 & 262,856 & & & 257 \\
\hline 86 & $\ldots$ & 182 & $1: 325$ & 257 \\
\hline 86 & & 182 & $1: 327$ & 257 \\
\hline 86 & 261 & & & 257 \\
\hline 56 & 6332 & 440 & $3: 23$ & 119 \\
\hline 64 & 485 & 338 & $2: 26 \cdot 2$ & 147 \\
\hline 54 & & 337 & $2: 261$ & 111 \\
\hline 41 & 29 & 20 & $1: 39$ & 71 \\
\hline 52 & 145 & & & 105 \\
\hline 61 & 105 & 76 & $1: 141$ & 136 \\
\hline 67 & 130 & 92 & $1: 170$ & 158 \\
\hline $\begin{array}{l}44 \\
44\end{array}$ & 377 & 265 & $2: 127$ & $\begin{array}{l}80 \\
80\end{array}$ \\
\hline 44 & 376 & & & 80 \\
\hline 44 & 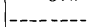 & 264 & $2: 126$ & 80 \\
\hline 21 & & & & 18 \\
\hline $\begin{array}{l}15 \\
15\end{array}$ & 459 & & $----1=$ & 2 \\
\hline $\begin{array}{l}15 \\
38\end{array}$ & $\ldots \ldots$ & $\begin{array}{l}320 \\
397\end{array}$ & $\begin{array}{l}2: 227 \\
2: 364\end{array}$ & (i1 \\
\hline 85 & 642 & 447 & $3: 40$ & 250 \\
\hline
\end{tabular}


Thespesia banalo Blanco pupulnea Corr
sublobata Blanco

Thon edulis Blanco

Name.

This work.

peirdula Blanco

Thumbergia fragrans Blarneo subsagittata Blanco

Thymelaeacer

Thymus biserratus Blanco virginicus Blanco.

Ticorea aculeata Blanco

Tiliace:e

Tillaea rubella Blanco

Tillandsia pseudo-ananas Blanco

Torenia paniculata Blanco soriana Blanco

Tourneforti arborea Blanco hirsutissima Blanco.

Tovomita pentupetala Blanco

Tradescantia cristata Jacq discolor Smith geniculata Blanco

Tragia bracteata Blanco innocua Blanco

Tremella Tribulus lanuginosus Blanco_

Trichilia pentandra Blanco rimosa Blanco -
tripetala Blanco tripetala Blanco

Trichosanthes amara Blaneo

Triopteris jamaicersis Blanco polyandra Blanco

Tristillateia malintana Blanco Triumfetta semitriloba Linn .

Turraea decandra Blanco _...... octandra Blanco virens Blanco.

Typhaceæ

Typha angustifolia Linn Ugena alba Blanco semihastata Blanco

Ulva compressa Blanco. intestinalis Blanco.

reticulata Blaneo umbilicalis Blanco

Umbelliferre

Unona calog Blanco camphorata Blanco cauliflora Blanco corniculate $\mathrm{Bla}$ dehiseens Blanco. latifolia Blanco odoratissima Blanco ossea Blanco setigera Blanco tripetala Blanco uncinata Blanco

Urena multifida Blanco

Urtica arborescens Blanco baccifera Blanco capitata Blanco

ferox Blanco

japonica Blanco

niver Linn

sessiliflora Blanco

umbellata Blanco

villosa Blanco

Uvaria amuyon Blanco
Blunco's Floru de Filipinas.

First second Third Appendition. edition. edition. dix.

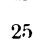

25
23

$2 \%$

23

$8: 2$

66

66

74
69

69

34

2.5

89

6.5

65

62

20

8

8

78

77

95
26

26

31

31

31

4

2:

26

30

31

30

90
90

90
95

78

81
81

81

80
80

81

81

80
80

80
81

17

-......

$601 \quad 419,2: 403$

\begin{tabular}{l|l|l|l|} 
& 382 & $2: 338$ & 25 \\
\hline-381 & $2: 337$
\end{tabular}

\begin{tabular}{ll|l}
381 & $2: 337$ & 25 \\
382 & $2: 338$ & 25
\end{tabular}

\begin{tabular}{ll|r}
382 & $2: 338$ & 25 \\
514 & $3: 146$ & 211
\end{tabular}

211

152

152

$18 \%$

164

164

349

29

286

148

148

138

138

17

272

273

272

196

\begin{tabular}{ll|l}
481 & $3: 94$ & 196 \\
4.9 & $3: 94$ & 194
\end{tabular}

578 3..

$2+5 \div 2: 91$

\begin{tabular}{l|l}
$2+9$ & $2: 97$
\end{tabular}

250，2:49

$248 \quad 2: 97$

249 2:98

533 3:178

$267: 2: 133$

$26 x$ ! 2:133

267 : $2: 132$

283 2: 161

17

389

214
243

$2: 89$

2: 88

687

477

3: 91

823

822

$8+2$

$8+2$

842

56 i.

$2: 38$

581 | 3:261

$5-2+3: 262$

$58.2+262$

\begin{tabular}{l|l|l|}
842 & 581 & $3: 261$ \\
\hline
\end{tabular}

466

468

469

466

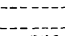

$2: 239$

- $2: 323$

2: 240

2: 238

$2: 236$

$325: 2: 237$

467

325

2: 239

467

468

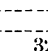

$324 \quad 2: 236$

324 2:237

540

\begin{tabular}{l|l}
378 & $2: 332$
\end{tabular}

\begin{tabular}{c|c|c}
- & 540 \\
\hdashline-095 & $3: 100$
\end{tabular}

695

483 3:101

694

484 3: 102

697

696

696

482 3:99

$484 \quad 3: 102$

695

463

\begin{tabular}{l|l}
483 & $3: 99$
\end{tabular} 


\begin{tabular}{|c|c|c|c|c|c|}
\hline \multirow{2}{*}{ Nume. } & \multirow{2}{*}{$\begin{array}{l}\text { This } \\
\text { work. }\end{array}$} & \multicolumn{3}{|c|}{$\begin{array}{c}\text { Blanco's Floru de } \\
\text { Filipinas. }\end{array}$} & \multirow{2}{*}{$\begin{array}{l}\text { Novis- } \\
\text { simu } \\
\text { Appen- } \\
\text { dix. }\end{array}$} \\
\hline & & $\begin{array}{c}\text { First } \\
\text { edition }\end{array}$ & $\begin{array}{l}\text { Second } \\
\text { edition. }\end{array}$ & $\begin{array}{l}\text { Third } \\
\text { edition. }\end{array}$ & \\
\hline Uvaria lanotan Blanco.. & 16 & 464 & & & \\
\hline ossea Blanco & 16 & & 322 & $2: 233$ & \\
\hline setigera Blanco & 15 & & 323 & $2: 234$ & \\
\hline co-non & 16 & 465 & & & \\
\hline $\begin{array}{r}\text { tripetala Blar } \\
\text { Vallea calomala Bla }\end{array}$ & 16 & 645 & & & \\
\hline $\begin{array}{l}\text { co } \\
\text { rpa Blaneo }\end{array}$ & 26 & $\begin{array}{l}439 \\
780\end{array}$ & & & \\
\hline $\begin{array}{l}\text { socarpa Blaneo } \\
\text { s Linn }\end{array}$ & $\begin{array}{l}82 \\
82\end{array}$ & 781 & $\begin{array}{l}538 \\
538\end{array}$ & $\begin{array}{l}3: 186 \\
3: 187\end{array}$ & \\
\hline Vandellia diffu & 65 & 505 & & 0.108 & \\
\hline 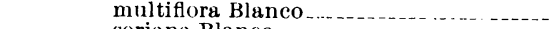 & 65 & 505 & & & \\
\hline - & 65 & 506 & & 2666 & \\
\hline anco & 53 & 167 & 117 & $1: 210$ & \\
\hline 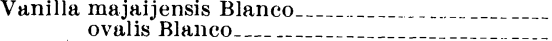 & 85 & & 593 & 3 & \\
\hline Vatica apteranthera Blanc & $\begin{array}{l}85 \\
22\end{array}$ & & $\begin{array}{l}448 \\
281\end{array}$ & & \\
\hline mangachapo & 22 & 401 & & & \\
\hline - & 22 & 401 & 280 & $2: 156$ & \\
\hline Ventilugo $\mathrm{n}$ & 32 & & 124 & $: 223$ & \\
\hline Verbenaceæ & 67 & & & & \\
\hline orsk & 67 & 19 & 14 & & \\
\hline - & 58 & 116 & 80 & & 12 \\
\hline neo & & 516 & 354 & & \\
\hline CO - & & $\begin{array}{l}014 \\
514\end{array}$ & $\begin{array}{ll}358 \\
3078\end{array}$ & & \\
\hline 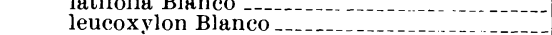 & $\begin{array}{l}68 \\
68\end{array}$ & 516 & $\begin{array}{l}358 \\
359\end{array}$ & & 16 \\
\hline 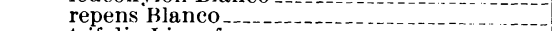 & 68 & 513 & $\begin{array}{l}3 \% 9 \\
358\end{array}$ & & \\
\hline & 68 & 513 & 358 & 97 & \\
\hline Volkameria ca & 69 & & 356 & $2: 294$ & \\
\hline … $\quad$ - & 69 & 511 & & & 161 \\
\hline $\mathrm{CO}$ & 68 & 512 & 357 & & 160 \\
\hline 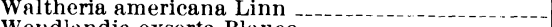 & 25 & 523 & 364 & & \\
\hline 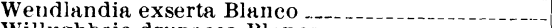 & 52 & & 104 & $1: 191$ & 106 \\
\hline Willughbeia dr & 57 & 132 & 94 & $1: 173$ & 123 \\
\hline Blaneo _. & 59 & 131 & 94 & $1: 172$ & 132 \\
\hline Blanco ................. & 20 & 131 & 94 & $1: 172$ & 34 \\
\hline lanco _........ & 55 & 629 & & & 116 \\
\hline Koenig - & 31 & 298 & 207 & & \\
\hline neo & $\begin{array}{c}91 \\
33\end{array}$ & 686 & 476 & & 314 \\
\hline 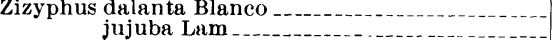 & $\begin{array}{l}33 \\
32\end{array}$ & & 121 & $1: 217$ & \\
\hline (n) & $\begin{array}{l}52 \\
33\end{array}$ & & $\begin{array}{l}120 \\
121\end{array}$ & & \\
\hline 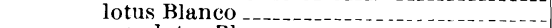 & 33 & & 121 & $1: 2$ & \\
\hline 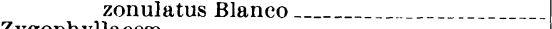 & 33 & & 120 & $1: 215$ & \\
\hline Zygo & & & & & \\
\hline
\end{tabular}




\section{PREVIOLS PUBLICATIONS OF THE BUREAC OP GOTER YBVT I HORATORIES.}

\section{(Continued from second page of cover.)}

No: 19, 1904, Biological Laboratory.-Some Observations on the Biology of the' 'nler: ' irillum. By W. B. Wherry $\mathrm{n}$.

No. 20, 1904, Piological Lat : - Does Latent or Dormant Plays: : $\mathrm{x}$ : there the Diseas" is Endemic? By Maximilian Perzog, M. D., and Charles $R$. '?rre. Scrum jaboratory: II. Broncho-Pneumoniu of Cattle: Its Association witl i;. Bovisepticus. Py Paul G. Woolley, M. D., and Walter Sorrell, D. V.S. IIl. Pinto (Paño Blanco). By Paul G. Woolley, M. D. Chemical Laboratory: IV. Notes on Analysis of the Water from the Manila Water Supply. By Charles L. Bliss. Serum Laboratory: V. Frambœsa: Its Occurrence in Natives in the Philippine Islands. By Paul G. Woolley, M. D.

No. 21, 1904, Biological Laboratory,-Some Questions Relating to the Virulence of MicroOrganisms, with Particul:ar Reference to Their Immunizing Powers. By Richard P. Strong, M. D.

No. 22, 1904, Bureau of Government Laboratories.-I. A Description of the New Buildings of the Bureau of Gorernment Laboratories. By Paul C. Freer, M. D., Ph. D. II. A Catalogue of the Library of the Bureau of Government Laboratories. By Mary Polk, Librarian.

No. 2S, 1904, Biologicai Lab, ;atory.-Plague: Bacteriology, Morbid Anatomy, and Histopathology (including a consideration of insects as plague carriers). By Maximilian Herzog, $M^{*}$. I).

No: 24, 1904, Biological Laboratory.-Glanders: Its Diagnosis and Prevention, together with a Report on Two Cases of Human Glanders Occu ring in Manila, and some Notes on the Bacteriology and Pleomorphism of Bacterium Mallei. By William B. Wherry, M. D.

* No. 25, 1904.-Firds from the Islands of Rombion, Sibuyan, and Creste de Gallo. By Richard C. McGregor.

No. 26, 190\%, Biological Laboratory.-The Clinical and Pathological Significance of Balantidium Coli. By Richard P. Strong, M. D.

Publications of the Bureau are given out in serial number pertaining to the entire Bureau. Publications which may be desired can be obtained by applying to the Librarian of the Bureau of Government Laboratories, Manila, P. I., ur to the Superintendent of Government Laboratories, Manila, P. I.

* The first four bulletins in the ornithological series were published by the Ethpological Survey udier the title "Bulletins of the Philippine Museum." Future ornithological publicati ins of the Government will appear as publications of the Bureau of Government Laboratories. 